TATIANA MONTEIRO RÉ

\title{
O USO DE FORMIGAS COMO BIOINDICADORES NO MONITORAMENTO AMBIENTAL DE REVEGETAÇÃO DE ÁREAS MINERADAS
}

Tese apresentada à Escola Politécnica da Universidade de São Paulo para obtenção do Título de Doutor em Engenharia. 
TATIANA MONTEIRO RÉ

\title{
O USO DE FORMIGAS COMO BIOINDICADORES NO MONITORAMENTO AMBIENTAL DE REVEGETAÇÃO DE ÁREAS MINERADAS
}

\author{
Tese apresentada à Escola \\ Politécnica da Universidade de São \\ Paulo para obtenção do Título de \\ Doutor em Engenharia. \\ Área de Concentração: \\ Engenharia Mineral \\ Orientador: \\ Prof. Dr. Giorgio de Tomi
}


Este exemplar foi revisado e alterado em relação à versão original, sob responsabilidade única do autor e com a anuência de seu orientador.

São Paulo, 14 de agosto de 2007.

Assinatura do autor

Assinatura do orientador

FICHA CATALOGRÁFICA

Re, Tatiana Monteiro

$\mathrm{O}$ uso de formigas como bioindicadores no monitoramento ambiental de revegetação de áreas mineradas / T.M. Re. - ed.rev. -- São Paulo, 2007.

244 p.

Tese (Doutorado) - Escola Politécnica da Universidade de São Paulo. Departamento de Engenharia de Minas e de Petróleo.

1.Minas (Planejamento) 2.Reabilitação de áreas degradadas (Mitigação) 3.Monitoramento ambiental 4.Meio ambiente I.Universidade de São Paulo. Escola Politécnica. Departamento de Engenharia de Minas e de Petróleo II.t. 
Para Ricardo e Lethicia 


\section{AGRADECIMENTOS}

Ao orientador e amigo Prof. Dr. Giorgio de Tomi, por sua percepção, compreensão, paciência, contribuições e sugestões fundamentais para o desenvolvimento desta tese.

A Millennium Chemicals - empresa do Grupo Lyondell Chemicals Company. Ao Setor de Meio Ambiente, pelo apoio, incentivo nos trabalhos de pesquisa e contribuições necessárias para a realização deste trabalho, em especial ao Geol. Renato Castro, Virgilio Gadelha Pinto e aos técnicos Claudeci e João Cirino. Ao Setor de Engenharia e Planejamento, em especial ao Engenheiro Manoel Bezerra e ao técnico de desenho Ronivaldo.

À USP, pela estrutura oferecida. Aos Professores e Funcionários do Departamento de Engenharia de Minas e do Petróleo da Escola Politécnica da USP, em especial aos amigos: secretários Washington, Bete, Mônica e Maristela, e as bibliotecárias Maria Cristina Martinez Bonesio, Elaine e Junko.

Aos Professores da banca examinadora do exame de qualificação, Dra. Elvira Gabriela Dias e Dra. Kátia Ferrari, pelos apontamentos, sugestões e contribuições importantes para finalização deste trabalho.

Ao Prof. Dr. Paulo Miranda, por acreditar na importância do tema desse estudo.

Ao Prof. Dr. Homero Delboni Junior pela ajuda nos momentos que precisei.

Aos colegas e amigos do LAPOL, Ricardo Ré, Ricardo (Barba), Nelson, Hary, Marcelino, Silvia, Bazante, Renato e Rondineli.

Ao Departamento de Ecologia da UNESP - Campus de Rio Claro, em especial ao Prof. Dr. Harold Gordon Fowler, às técnicas Sueli e Sandra e à grande amiga Paula, pela contribuição e apoio científico, e hospitalidade durante minha estadia em Rio Claro.

Ao Prof. Dr. Flávio Henrique Caetano, especialista em mirmecologia do Departamento de Biologia da UNESP - Campus de Rio Claro (SP), pelas correções e orientações. 
À Engenheira Kilma Cunha do Departamento de Geologia/Mina da Mineração Onça Puma, Empresa CVRD, pelo relatório interno enviado com comentários e sugestões.

Aos amigos Lílian, Alberto, Fábio, pelos ensinamentos e aos amigos Prof. Raimundo (JPA), Adriana Kátia (MCH), Érika Guiducci, Patrícia Curtolo pelas incansáveis revisões no texto e suporte técnico.

A toda a minha família, meu pai, minha mãe, irmão e avó, pelas orações e apoio incondicional.

Muito obrigada. 
"Não é a Terra que é frágil. Nós é que somos frágeis. A natureza tem resistido a catástrofes muito piores do que as que produzimos. Nada do que fazemos destruirá a natureza. Mas podemos facilmente nos destruir".

James Lovelok 


\section{RESUMO}

As atividades de mineração são o suporte do crescimento e do desenvolvimento econômico da sociedade moderna. Por outro lado, estas atividades são causadoras de consideráveis modificações ambientais. Assim, faz-se necessário o desenvolvimento da Avaliação de Impacto Ambiental, que vise a definição de planos de controle ambiental que garanta a mitigação de tais impactos, bem como o seu monitoramento para verificação da eficácia das medidas definidas. Esta avaliação é uma exigência da Constituição Brasileira de 1988: toda atividade poluidora deve recuperar os danos causados ao meio ambiente. A obrigação de recuperar consiste em repor a área em uma situação de normalidade e estabilidade. Desta forma, algumas medidas mitigadoras, como a reposição vegetal e a reimplantação da fauna, estão sendo tomadas por alguns empreendimentos, as quais medidas necessitam ser monitoradas, a fim de permitir a avaliação de sua eficácia e evolução ao longo do tempo. O biomonitoramento é uma prática nova nas ciências ambientais. Este estudo propõe uma metodologia de monitoramento biológico capaz de avaliar a eficácia e a evolução das técnicas de revegetação na mineração. Como estudo de caso, foi selecionada a Millennium Chemicals - empresa que pertence ao Grupo Lyondell Chemicals Company - que produz minerais pesados, na Mina do Guaju, localizada no extremo norte do Estado da Paraíba. Trata-se de uma proposta metodológica que visa uma simples e prática aplicabilidade, permitindo a continuidade do biomonitoramento ambiental por um longo período de tempo com a utilização de insetos, em especial da Família Formicidae. Além da proposta de metodologia, este trabalho também contempla resultados e análises do total de três coletas, que foram realizadas ao longo de um ano. A metodologia desenvolvida, incluindo os processos de coletas e análise de resultados, representa uma contribuição importante para a redução de custos despendidos para o processo de gerenciamento ambiental de empresas de mineração, através de um melhor direcionamento dos procedimentos ambientais adotados, sua relação com o 
planejamento de lavra, e permitindo um monitoramento da área afetada pela mineração.

Palavras-chave: Minas (Planejamento). Reabilitação de áreas degradada (Mitigação). Monitoramento ambiental. Meio ambiente. 


\section{ABSTRACT}

The mining industry is known to contribute to the growth and the economic development of modern society. However, these activities may generate considerable modifications to the environment. Therefore, it is necessary the development of an Environmental Impact Evaluation that aims the definition of the environmental control plans that guarantee the mitigation of such impacts, as well as their monitoring to check the effectiveness of the defined measures. Such a plan is a now requirement introduced by the Brazilian Constitution of 1988: all polluting activities must recover the actual damages to the environment. Because of that, procedures such as vegetation replacement and re-establishment of the fauna are being taken by most companies of mining where rehabilitation measures need to be monitored, in order to allow the evaluation of its effectiveness and progress throughout time. Biomonitoring is a new monitoring practice in environmental science. The present research work has the objective of developing a biological automonitoring methodology for evaluating the effectiveness and the progress of revegetation techniques in mined-out areas. As study case, it was selected Millennium Chemicals - a company that belongs to Lyondell Chemicals Company - that produces heavy minerals in Mina do Guaju, located in the extreme north of Paraíba State. The proposed methodology includes a simple and practical way for measuring biomonitored environment for an extended period of time with the use of insects, with particular focus on the Formicidae Family. In addition to the methodology proposed, this research work also contemplates preliminary results and analysis of the first collection, of the total of three collections, which should be carried throughout one year. The methodology proposed, which include data collection and analysis of results, represents an important contribution for the reduction of costs of environmental management of mining companies, through better environmental control procedures, and their relation with mine planning, and auto-monitoring of the areas eventually affected by mining activities. 
Keywords: Mines (Planning). Rehabilitation of degraded areas (Mitigation). Environmental monitoring. Environment. 


\section{LISTA DE FIGURAS}

Figura 1 - Fluxo das etapas de biomonitoramento ambiental.

Figura 2 - Diagrama esquemático da disposição das armadilhas "Pitfall's".

Figura 3 - Diagrama de metodologia de biomonitoramento ambiental: produtos e resultados de cada etapa

Figura 4 - Localização da área de estudo - Mina do Guaju.

Figura 5 - Primeira pilha de rejeito no início do processo de recuperação estudos pioneiros de recuperação ambiental em 1989.

Figura 6 - Primeira pilha de rejeito com sete anos de desenvolvimento do processo de recuperação, 1996.

Figura 7 - Vista sistema de lavra: escavação mecanizada a seco.

Figura 8 - Detalhe da correia transportadora do sistema de lavra.

Figura 9 - Processo de reconstituição de dunas, a partir da disposição da pilha de rejeito na área já lavrada.

Figura 10 - Desenho esquemático da lavra mecanizada a seco.

Figura 11 - Desenho esquemático da lavra com método de dragagem.

Figura 12 - Compartimentação Geológica Regional. Compilação de parte do mapa geológico da Paraíba.

Figura 13 - Pré-desmatamento manual.

Figura 14 - Desmatamento mecânico - decapeamento da camada orgânica.

Figura 15 - Início da etapa de transporte da matéria orgânica.

Figura 16 - Descarregamento da matéria orgânica no topo da duna a ser recapeada.

Figura 17 - Espalhamento do solo nas pilhas de rejeito, mostrando detalhe dos quebra-ventos físicos. 
Figura 18 - Disposição de quebra-ventos físicos e biológicos.

Figura 19 - Processo de revegetação: A - medição das covas para plantio;

B - Capina no local da cova; C - Preparação das covas; D - Composto para adubação nas covas; E - Plantio das mudas.

Figura 20 - Duna recuperada com 13 anos.

Figura 21 - Processo de adensamento de espécies em dunas já inicialmente revegetadas.

Figura 22 - Casa de vegetação, viveiro de mudas.

Figura 23 - Criadouro Conservacionista.

Figura 24 - Viveiro de Quarentena.

Figura 25 - Localização das áreas de coletas de formigas.

Figura 26 - Vista aérea das lagoas - local das áreas de referência.

Figura 27 - Fotos de detalhes da Área Controle 1 (AC1): A e C - porte da vegetação; $B$ - armadilha sinalizada; $D$ - presença de serapilheira.

Figura 28 - Fotos de detalhes da Área Controle 2 (AC2): A e C - porte da vegetação; $B$ - armadilha sinalizada; D - presença de serapilheira.

Figura 29 - Fotos de detalhes da área de plantio do ano de 1989 (A89): A,

$B$ e $C$ - porte da vegetação; $D$ - presença de serapilheira.

Figura 30 - Fotos de detalhes da área de plantio de 1992 (A92): A, C e

$D$ - porte da vegetação; $B$ - presença de serapilheira.

Figura 31 - Fotos de detalhes da área de plantio de 1995 (A95): A,B e

$C$ - porte da vegetação; $D$ - presença de serapilheira.

Figura 32 - Fotos de detalhes da área de plantio de 2000 (A00): A, B, C - porte da vegetação.

Figura 33 - Detalhe das armadilhas demarcadas com piquetes e fitas, no campo.

Figura 34 - Conservação das formigas triadas. 
Figura 35 - Coleção de referência - Catálogo de espécies de formigas.

Figura 36 - Ranque de abundância de espécies e gêneros das áreas de coletas.

Figura 37 - Gráfico de freqüência relativa de todos os gêneros coletados na

Área Controle 1 (AC1).

Figura 38 - Gráfico de freqüência relativa de todos os gêneros encontrados na Área Controle 2 (AC2).

Figura 39 - Gráfico de freqüência relativa de todos os gêneros encontrados na Área de plantio 1989 (A89).

Figura 40 - Gráfico de freqüência relativa de todos os gêneros encontrados na Área de plantio 1992 (A92).

Figura 41 - Gráfico de freqüência relativa de todos os gêneros encontrados na Área de plantio 1995 (A95).

Figura 42 - Gráfico de freqüência relativa de todos os gêneros encontrados na Área de plantio 2000 (A00).

Figura 43 - Correlação linear entre similaridade e a afinidade.

Figura 44 - Dendograma de similaridade das seis áreas de coletas.

Figura 45 - Porcentagem de gêneros registrados em cada um dos grupos funcionais classificados por Andersen e Brown (2000).

Figura 46 - Gêneros registrados em cada grupo funcional na Área Controle 1 (AC1).

Figura 47 - Gêneros registrados em cada grupo funcional na Área Controle 2 (AC2).

Figura 48 - Gêneros registrados em cada grupo funcional na Área 1989 (A89).

Figura 49 - Gêneros registrados em cada grupo funcional na Área 1992 (A92).

Figura 50 - Gêneros registrados em cada grupo funcional na Área 1995 (A95). 
Figura 51 - Gêneros registrados em cada grupo funcional na Área 2000 (A00).

Figura 52 - Porcentagem de gêneros registrados em cada um dos grupos

funcionais classificados por Bestelmeyer e Wiens (1996).

Figura 53 - Gêneros registrados em cada grupo funcional na Área Controle 1 (AC1).

Figura 54 - Gêneros registrados em cada grupo funcional na Área Controle 2 (AC2).

Figura 55 - Gêneros registrados em cada grupo funcional na Área 1989 (A89).

Figura 56 - Gêneros registrados em cada grupo funcional na Área 1992 (A92).

Figura 57 - Gêneros registrados em cada grupo funcional na Área 1995 (A95).

Figura 58 - Gêneros registrados em cada grupo funcional na Área 2000 (A00).

Figura 59 - Comportamento dos grupos funcionais classificados por Andersen e Brown, nas seis áreas desse estudo.

Figura 60 - Comportamento dos grupos funcionais classificados por Bestelmeyer e Wiens, nas seis áreas desse estudo.

Figura 61 - Correlação esquemática existente entre diversidade e dominância de espécies. 


\section{LISTA DE QUADROS}

Quadro 1 - Períodos e processos envolvidos nas etapas de recuperação ambiental

Quadro 2 - Técnicas de recuperação da fauna.

Quadro 3 - Classificação dos grupos funcionais do Chaco argentino.

Quadro 4 - Matriz de similaridade dos gêneros registrados nas seis áreas de coleta. 


\section{LISTA DE TABELAS}

Tabela 4.1 - Coordenadas UTM de alguns vértices que delimitam a área da Mina do Guaju.

Tabela 4.2 - Produção de minerais pesados na Mina do Guaju.

Tabela 4.3 - Média mensal dos índices pluviométricos coletados entre 1996 e 2001.

Tabela 4.4 - Listagem de espécies vegetais encontradas ao longo do transecto das armadilhas, na Área Controle 1.

Tabela 4.5 - Listagem de espécies vegetais encontradas ao longo do transecto das armadilhas, na Área Controle 2.

Tabela 4.6 - Listagem de espécies vegetais encontradas ao longo do transecto das armadilhas, na área de plantio do ano de 1989.

Tabela 4.7 - Listagem de espécies vegetais encontradas ao longo do transecto das armadilhas, na área de plantio do ano de 1992.

Tabela 4.8 - Listagem de espécies vegetais encontradas ao longo do transecto das armadilhas, na área de plantio do ano de 1995.

Tabela 4.9 - Listagem de espécies vegetais encontradas na área de plantio do ano de 2000.

Tabela 4.10 - Coordenadas UTM dos pontos de coletas.

Tabela 4.11 - Cronograma das Atividades de Campo, seguidas para a Mina do Guaju.

Tabela 5.1 - Número de formigas coletadas. 
Tabela 5.2 - Número de gêneros e espécies de formigas registradas em cada área de coleta.

Tabela 5.3 - Freqüência dos gêneros de formigas nas áreas de coletas.

Tabela 5.4 - Análise de Similaridade e de Afinidade das Áreas de Estudos.

Tabela 5.5 - Sumário Estatístico das Análises.

Tabela 5.6 - Classificação dos grupos funcionais desenvolvidos por Andersen e Brown Jr (2000) para os respectivos gêneros de formigas registrados nas coletas 2 e 3 .

Tabela 5.7 - Classificação dos grupos funcionais desenvolvidos por Bestelmeyer e Wiens (1996) para os respectivos gêneros de formigas registrados nas coletas 2 e 3 . 


\section{SUMÁRIO}

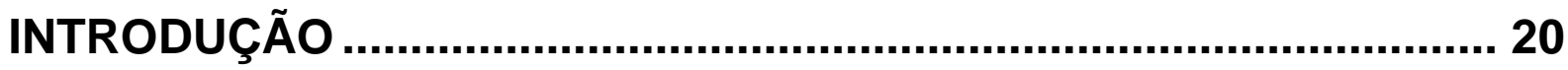

\section{CAPÍTULO 1}

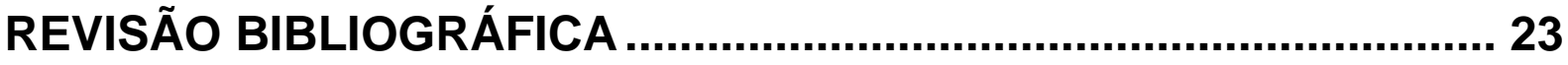

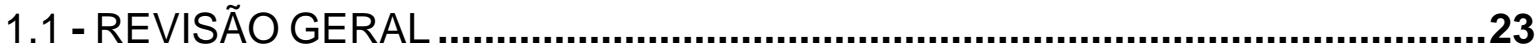

1.2 - RECUPERAÇÃO DE ÁREAS DEGRADADAS PELA MINERAÇÃO................29

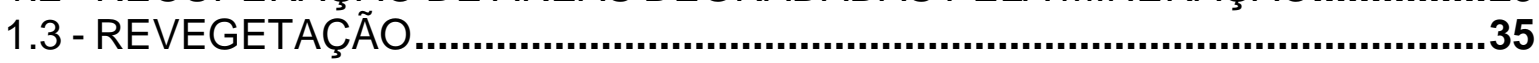

\section{CAPITULO 2}

MONITORAMENTO AMBIENTAL ................................................... 45

2.1 - O MONITORAMENTO AMBIENTAL NA MINERAÇÃO ................................45

2.2 - O MONITORAMENTO AMBIENTAL NA RECUPERAÇÃO DE ÁREAS

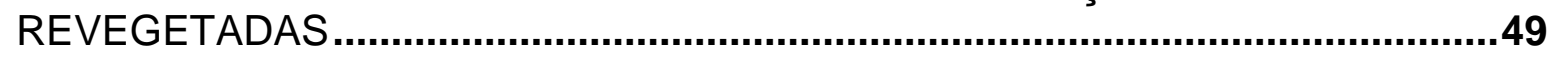

2.3 - O USO DE INDICADORES NO MONITORAMENTO ….................................55

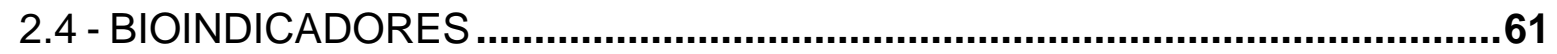

2.5 - AS FORMIGAS COMO INDICADORAS DA QUALIDADE AMBIENTAL..........66

2.5.1 Métodos de coleta de formigas......................................................71

2.6 CLASSIFICAÇÃO DAS FORMIGAS EM GRUPOS FUNCIONAIS ..................77

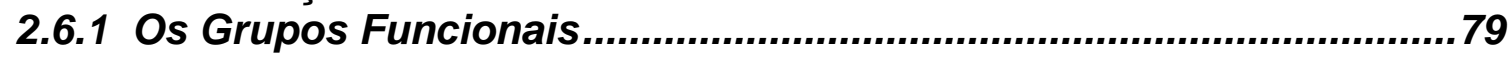

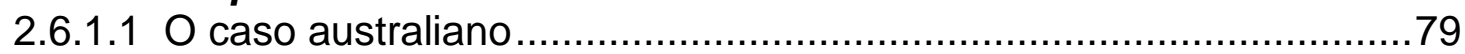

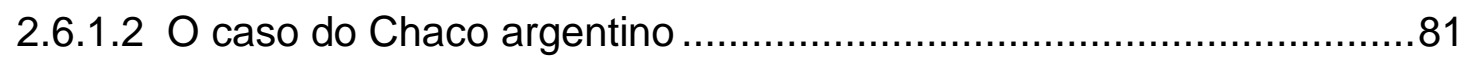

2.6.2 Descrição dos Grupos Funcionais .....................................................83

\section{CAPÍTULO 3}

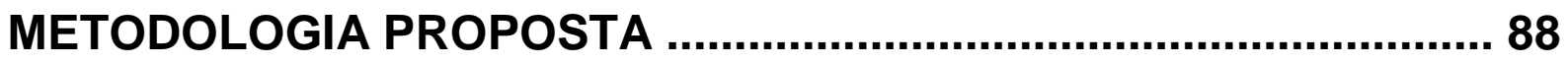

3.1 ESCOLHA DO BIOINDICADOR ...............................................................90

3.2 MÉTODO DE AMOSTRAGEM DE FORMIGAS.............................................90

3.3 DEFINIÇÃO DA PERIODICIDADE .............................................................93

3.4 ESCOLHA DAS ÁREAS DE COLETAS.......................................................94

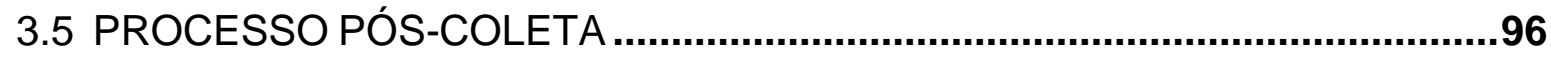

\section{CAPÍTULO 4}

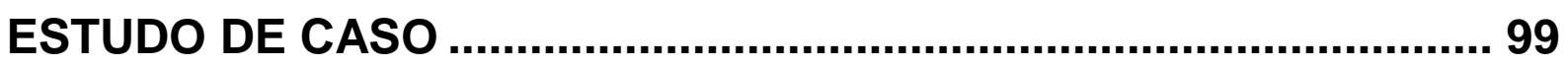

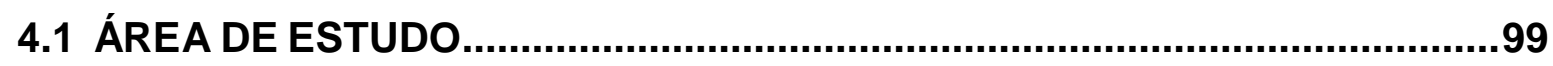

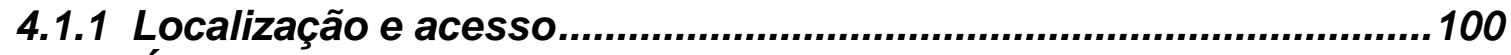

4.1.2 Área do projeto Mina do Guaju .....................................................102

4.1.3 Histórico......................................................................................102

4.1.4 Método de lavra e recomposição do relevo.....................................106

4.1.4.1 Escavação mecanizada a seco ...............................................107

4.1.4.2 Lavra por dragagem ...........................................................111

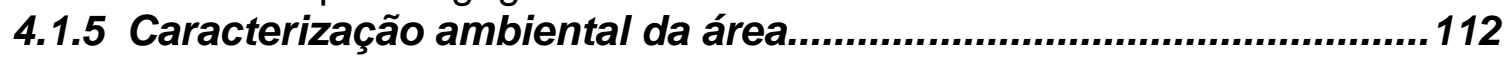

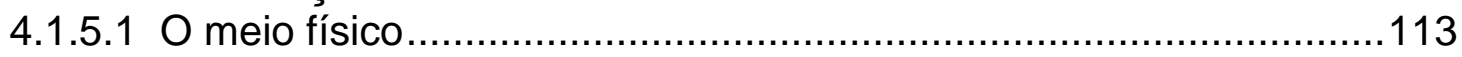

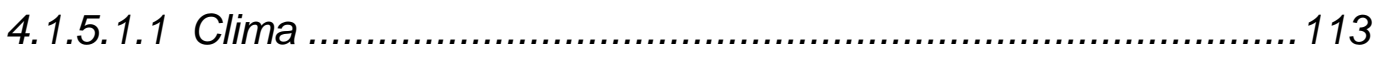


4.1.5.1.2 Geologia ..................................................................... 114

4.1.5.1.3 Geomorfologia ......................................................... 116

4.1.5.1.4 Solos............................................................................. 116

4.1.5.1.5 Recursos Hídricos ........................................................ 118

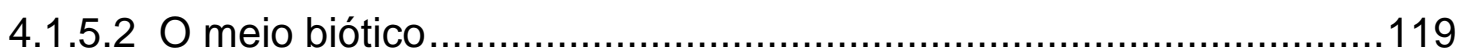

4.1.5.2.1 Flora: descrição das formações vegetais existentes ...............119

4.1.5.2.2 Fauna : descrição dos grupos faunísticos estudados.............122

4.1.6 Processo de recuperação de pilhas de rejeito ..................................123

4.1.7 Outras atividades que subsidiam o processo de recuperação.........134

4.2 APLICAÇÃO METODOLÓGICA ...............................................................136

4.2.1 Escolha das áreas de coletas ........................................................136

4.2.2 Caracterização de cada área de coleta............................................139

4.2.2.1 Áreas Controle (AC1 e AC2) .....................................................139

4.2.2.1.1 Área Controle 1 (AC1) .................................................... 140

4.2.2.1.2 Área Controle 2 (AC2) ................................................ 145

4.2.3 Áreas em diferentes etapas de recuperação ...................................149

4.2.3.1 Plantio 1989 (A89) ................................................................149

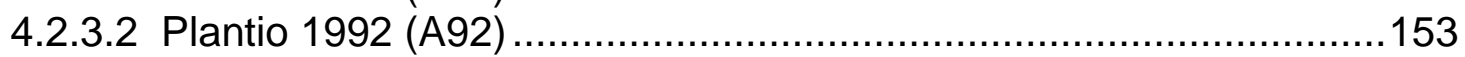

4.2.3.3 Plantio 1995 (A95) ............................................................ 156

4.2.3.4 Plantio 2000 (A00) ...............................................................159

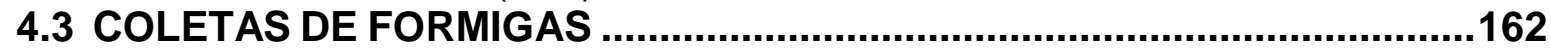

CAPÍTULO 5

RESULTADOS, ANÁLISE E DISCUSSÃO.....................................166

5.1 ANÁLISE DOS RESULTADOS ...........................................................166

5.1.1 Análise de Diversidade ......................................................................167

5.1.2 Análise de Afinidade e Similaridade................................................ 176

5.1.3 Análise de Agrupamento ..................................................................181

5.1.4 Análise de Grupos Funcionais........................................................182

5.1.4.1 Grupos funcionais caracterizados a partir dos dados dos grupos funcionais da Austrália..........................................................................183

5.1.4.2 Grupos funcionais caracterizados a partir dos dados dos grupos funcionais do Chaco argentino ........................................................ 191

CAPÍTULO 6

CONCLUSÕES .............................................................................207

REFERÊNCIAS BIBLIOGRÁFICAS ..........................................211

GLOSSÁRIO...........................................................................230

APÊNDICE A - LISTAGEM DE ESPÉCIES DAS FORMIGAS

(SUBFAMÍLIA, TRIBO, GÊNERO E ESPÉCIE) COLETADAS NA ÁREA DE ESTUDO. ...........................................................................238

ANEXO A - MAPA DO LIMITE DAS ÁREAS DO DECRETO DE LAVRA: ÁREA DE LAVRA E ÁREA DE SERVIDÃO ......................240

ANEXO B - MAPA DE VEGETAÇÃO ........................................241 
ANEXO C - LISTAGEM DE ESPÉCIES PRODUZIDAS PARA O PLANTIO DE 2002

ANEXO D - MAPA DE DELIMITAÇÃO DOS PLANTIOS: DE 1989 A 2002 .243 ANEXO E - CLASSIFICAÇÃO DOS GRUPOS FUNCIONAIS DAS FORMIGAS DO CHACO ARGENTINO.............................................24 


\section{INTRODUÇÃO}

A mineração é uma atividade extrativa e essencial à sociedade moderna, pois gera produtos importantes e indispensáveis ao desenvolvimento econômico de uma nação. Porém, devido aos fortes impactos ambientais gerados por suas atividades é fundamental que estas empresas atuem de forma responsável e sustentável, gerenciando os riscos ambientais associados.

Assim, diante da crescente preocupação mundial pela busca de qualidade ambiental e sustentabilidade dos recursos naturais, faz-se necessário o reconhecimento dos impactos ambientais potencialmente prejudiciais à sociedade, sendo que tais impactos, causados por ações e projetos, devem ser evitados ou atenuados ainda na fase de planejamento dos empreendimentos.

Vários esforços foram e continuam sendo feitos pela sociedade e por órgãos ambientais regulamentadores no sentido de controlar os impactos da mineração. Atualmente, a partir de um bom planejamento, é possível adotar tecnologias evoluídas e aplicáveis por equipes qualificadas, buscando o restabelecimento do local afetado, limitando o impacto ambiental negativo e potencializando os impactos positivos, ao longo de toda a vida do empreendimento.

O desafio para a mineração é monitorar os impactos ambientais negativos e controlar seus efeitos de forma a não comprometer suas atividades, mas por outro lado, sem impactar a viabilidade econômica da atividade. Surge assim a necessidade de conciliar o desenvolvimento econômico desejado diante de um ambiente saudável, levando em consideração que evitar ou atenuar os impactos ambientais negativos é sempre melhor do que somente corrigir os danos ambientais causados.

Embora a prática efetiva do monitoramento ambiental não seja atualmente adotada pela maioria dos empreendimentos de mineração, trata-se de um instrumento de gestão ambiental pós-Estudo de Impacto Ambiental (pós-EIA) essencial, que garante a melhoria e eficiência das medidas mitigadoras, definidas a partir do EIA, assegurando 
o efetivo funcionamento dos processos estabelecidos para proteger o ambiente e atingir os resultados esperados.

O monitoramento implantado é capaz de auxiliar as tomadas de decisões quanto às correções que se fizerem necessárias durante o processo de implantação e operação de uma atividade modificadora do meio ambiente, uma vez que este permite a detecção de falhas durante a operação das atividades.

A presente pesquisa propõe uma metodologia de monitoramento biológico capaz de avaliar a eficácia e o desenvolvimento das técnicas de revegetação adotadas pela indústria mineral. Com a aplicação dessa metodologia é realizado um levantamento qualitativo das espécies de formigas presentes no local, o que permite enriquecer os dados ambientais e caracterizar o ambiente local das áreas em diferentes fases de recuperação da mina; dados contribuintes necessários que devem ser utilizados para confrontar com novos dados a serem coletados, possibilitando o monitoramento ambiental.

A coleta, dos indicadores ambientais a serem monitorados (espécies de formigas), quando realizada juntamente com os inventários dos Estudos de Impactos Ambientais (EIA), acaba por auxiliar e acelerar a busca de respostas mais plausíveis ao longo do biomonitoramento ambiental, mas, a ausência destes dados no início do planejamento ambiental não impede que o biomonitoramento seja aplicado com sucesso.

A metodologia foi testada junto a uma empresa de mineração de minerais pesados, localizada no extremo norte do Estado da Paraíba, a fim de qualificar o novo ecossistema implantado como medida mitigadora dos impactos gerados por suas atividades. Os resultados das coletas de amostras foram registrados, analisados e utilizados como base para as conclusões sobre os benefícios dessa metodologia na mineração.

A proposta metodológica visa a uma simples e prática aplicabilidade, permitindo a continuidade do biomonitoramento ambiental, por um longo período de tempo, para que auxilie o gerenciamento ambiental do empreendimento.

A pesquisa possibilita o aperfeiçoamento da elaboração de programas de monitoramento ambiental para empreendimentos de mineração que adotem práticas de 
revegetação, e a metodologia proposta é um instrumento útil no controle da qualidade ambiental das atividades da indústria mineral.

O resultado dessa pesquisa é apresentado em seis capítulos. No Capítulo 1 Revisão Bibliográfica - é abordada a necessidade da adoção de monitoramento ambiental das medidas mitigadoras adotadas por empreendimentos que possuam atividades potencialmente poluidoras e enfatiza a importância do setor de mineração e sua obrigação de recuperar e monitorar áreas mineradas; além de abordar as práticas adotadas, caracterizam-se as principais etapas de um processo de recuperação.

O Capítulo 2 aborda o monitoramento ambiental e o uso de organismos bioindicadores, em especial a família de insetos Formicidae, como capazes de qualificar o novo ecossistema formado, através de metodologias eficazes contribuintes com dados que permitam um monitoramento ambiental da área afetada pelo processo de mineração.

No Capítulo 3 é proposta a metodologia de biomonitoramento ambiental capaz de avaliar e qualificar o desenvolvimento das áreas em processo de revegetação, contribuindo para o aperfeiçoamento da técnica de revegetação utilizada; e, no Capítulo 4 - Estudo de Caso - tal proposta é aplicada nas pilhas de rejeito, que estão em processo de recuperação na Mina do Guaju, propriedade da Lyondell Chemicals Company. - Paraíba, a qual vem adotando técnicas especificas de revegetação desde 1988.

Todos os dados coletados com a aplicação da metodologia foram avaliados estatisticamente e apresentados no Capítulo 5, onde são apresentadas análises e interpretações dos resultados. Por fim, no Capítulo 6 - Conclusões - são destacados os principais pontos que permitiram comprovar a eficácia da metodologia proposta.

A metodologia proposta consiste em uma técnica que permite auxiliar as tomadas de decisões de planejamento do empreendimento, contribuindo com a redução de custos despendidos para o processo de monitoramento ambiental, modo a aperfeiçoar o gerenciamento ambiental da mineração. 


\section{CAPÍTULO 1}

\section{REVISÃO BIBLIOGRÁFICA}

\subsection{REVISÃO GERAL}

As atividades de mineração são consideradas, segundo CAVALCANTI (1995), como indispensáveis à continuação do progresso econômico dos países em desenvolvimento e essenciais à manutenção do nível de crescimento alcançado pelos países desenvolvidos. É uma atividade geradora de produtos importantes para a economia e para a sociedade atual, portanto, suporte do crescimento e do desenvolvimento econômico.

A atividade extrativa mineral é geradora de consideráveis modificações ambientais, a intensidade destas modificações é sempre proporcional ao volume, tipo de mineração e rejeitos produzidos pela mina em particular, pois cada tipo de minério exige processos específicos de pesquisa, lavra, beneficiamento e controle ambiental, por apresentarem características distintas de acordo com sua localização geográfica e de seus contextos geomorfológicos.

Os principais impactos ao meio associado à atividade da indústria mineral e abertura de uma nova frente de lavra, em geral, resumem-se a impactos no solo, visual, no ar, na água e poluição sonora. Estes impactos acabam interferindo na fertilidade natural e na queda das atividades biológicas dos solos, mudanças de drenagem, e outros fatores que alteram as condições de recuperação do ambiente (OLIVEIRA JR, 2001).

Tendo em vista os danos ambientais ocasionados e considerando que a atividade de mineração é uma forma temporária de uso do solo, muitas vezes integrada 
a um contexto sócio-econômico, o qual prioriza outras formas de ocupação da terra, faz-se necessária a implantação de um Plano de Controle Ambiental (PCA) que garanta a atenuação dos impactos associados às atividades desenvolvidas pelo empreendimento, bem como o seu monitoramento, para a verificação da eficácia das medidas mitigadoras definidas (IBRAM, 1987).

A aplicação do PCA, durante toda a vida útil da mina, constitui o primeiro passo para assegurar o retorno à coletividade de uma área em condições de abrigar novos usos e novas formas de ocupação (OLIVEIRA JR.; BRUM, 1998).

Os impactos sobre os ecossistemas gerados pelas empresas mineradoras requerem formas diferenciadas de gerenciamento, uma vez que ocorrem na forma de destruição ou modificação de habitats, de limitação da disponibilidade de recursos (energia, água ou nutrientes), ou da criação de diversos tipos de estresses (emissões de poluentes e movimentação de pessoas e/ou veículos) (SÁNCHEZ, 1994).

Entre as ações de gerenciamento incluem-se as limitações das áreas a serem desmatadas, o manejo de fauna e a recuperação de habitats, e, nesse caso, o monitoramento é um componente essencial do processo de gerenciamento, que são monitorados parâmetros, dependentes do tipo de ecossistema e incluem indicadores físicos, químicos e biológicos. (SÁNCHEZ, op. Cit.).

Nesse sentido, urge uma preocupação com o planejamento adequado de todo o processo de lavra dos recursos naturais, definindo-se objetivos claros sobre o uso futuro da área a ser lavrada. A Avaliação de Impacto Amabiental (AIA) requer a elaboração de um programa de acompanhamento e monitoramento dos impactos ambientais de todo o projeto e do desempenho ambiental do empreendimento nas fases de implantação, operação e desativação (BRANDI, 1994).

Com a Constituição Brasileira de 1988, a legislação ambiental passa a exigir, a partir de adaptações da Lei Ambiental $n^{\circ}$ 6938/81, que toda atividade poluidora, incluindo as minerações, recupere, obrigatoriamente, os danos causados por suas atividades desenvolvidas (MACHADO, 1995), responsabilidade essa que até então era quase inexistente. Anteriormente, pouquíssimas empresas vinham desenvolvendo trabalhos conservacionistas de forma voluntária. 
Esta lei é reconhecida como o principal marco na introdução da AIA, no Brasil (DIAS, 2001), atualmente considerada como um importante instrumento das futuras conseqüências de ações humanas sobre o meio ambiente (CAVALCANTI, 1995; SÁNCHEZ, 1993).

Conforme as Resoluções estabelecidas pelo Conselho Nacional de Meio Ambiente: CONAMA 001/86 e CONAMA 237/97, a avaliação de impactos ambientais se tornou parte integrante do processo de licenciamento ambiental de atividades com potencial à poluição e/ou degradação do meio ambiente (PRADO FILHO e SOUZA, 2002). Com o aperfeiçoamento da política ambiental brasileira, todas as minerações passaram a dar maior ênfase às questões ambientais no planejamento e gerenciamento ambiental de suas atividades (BRANDI, 1994).

Os princípios que estabelecem a AIA como instrumento da política ambiental tem uma ampla aplicabilidade, entretanto, normalmente são utilizados para a obtenção da licença ambiental. A AIA é um instrumento da política ambiental que pode e deve ter seus princípios e métodos utilizados de forma a auxiliar as decisões internas ao nível de projeto, não apenas como um conjunto de técnicas e atividades que visam assegurar que o empreendimento opere dentro dos padrões legais ambientais exigidos, mas também como um instrumento de apoio que auxilie nos processos de tomadas de decisões, seja na seleção de alternativas ou no planejamento em longo prazo (SÁNCHEZ, 1993; BRANDI 1994; SÁNCHEZ, 1994).

Uma completa avaliação de todas as etapas do empreendimento deve ser realizada visando o levantamento de todos os possíveis impactos ambientais que suas futuras atividades poderão gerar. Tal avaliação é exigida legalmente pelos órgãos ambientais e deve ser contemplada na fase de elaboração do Estudo de Impacto Ambiental e seu respectivo Relatório de Impacto Ambiental (EIA/RIMA), a partir dos quais é possível determinar os principais danos e planejar medidas eficazes para a mitigação destes, como um adequado Programa de Recuperação de Áreas Degradadas (PRAD) (BRANDI, 1994).

Segundo BRANDI (op.Cit.), o CONAMA passou a exigir o PRAD para áreas cujas condições naturais de equilíbrio tenham sido alteradas por atividades de mineração, através do art. $2^{\circ}$, inciso VIII, da Lei 6.938/81, pelo Decreto-Lei 97.632/89. 
Inserido como um instrumento complementar ao EIA/RIMA, o PRAD é um dos principais instrumentos de planejamento e gerenciamento ambiental no processo de Avaliação de Impactos Ambientais (AIA), o que almeja garantir a plena recuperação da área degradada (MUNNO, 2005).

A importância do PRAD como instrumento de gerenciamento ambiental refere-se à capacidade de sintetizar, num mesmo documento, os recursos naturais das áreas de influência da jazida e os impactos ambientais provocados pela implantação do projeto, permitindo, juntamente com o Estudo de Impacto Ambiental (EIA/RIMA), traçar os objetivos da recuperação ambiental dentro de condições específicas para cada área degradada.

Além disto, o PRAD é um documento que contempla as metodologias de avaliação dos impactos ambientais e os processos de tomada de decisões na implantação de medidas que alteram a qualidade ambiental das áreas situadas nas imediações das jazidas, tornando-se uma excelente fonte de dados e informações para os órgãos fiscalizadores e pelas próprias empresas do setor mineral (SÁNCHEZ, 1993).

Para CAMPELLO de CASTRO (1998), recuperar áreas degradadas vai muito além de uma simples formalidade legal e se fundamenta na obrigatoriedade de reparar o dano causado ao meio ambiente. A obrigação de recuperar, prevista na legislação, consiste em reconduzir a área numa situação de normalidade e estabilidade. Assim, algumas medidas atenuadoras devem ser implantadas antes e durante a operação dos processos adotados pela mineração, com a finalidade de se promover a recuperação da vegetação local (GRIFFITH, 1980).

Entre as medidas mitigadoras destacam-se a suavização dos taludes, o armazenamento da camada superior do solo da área a ser lavrada, o aterro progressivo das escavações das áreas já lavradas, o tratamento dos solos mais problemáticos e a seleção do elenco de espécies mais adequadas que farão parte do plantio. Outras medidas seriam: a retenção física do solo para atenuar os problemas de drenagem e de erosão hídrica, a regularização da topografia e o condicionamento do solo para o plantio do vegetal (IBRAM, 1992).

Além do atendimento ao aspecto legal, deve-se ressaltar que existem inúmeras vantagens, inclusive econômicas, as quais justificam a abordagem da recuperação, já 
na fase de planejamento da mina a ser explorada. Como exemplo, pode-se citar as operações de decapeamento da área que prevêem uma correta estocagem, conservação e recolocação da camada fértil do solo no local alterado. Tais medidas não só diminuirão os impactos ambientais, mas também reduzirão os custos necessários para a recuperação do ambiente, comparados aos custos da realização destes procedimentos somente no final da lavra (OLIVEIRA JR.; BRUM, 1998).

As técnicas adotadas para recuperação das áreas degradadas variam em função da intensidade da interferência ocorrida e das características da lavra e do minério, declividade e tipo de terreno. A recomposição vegetal é uma das principais práticas de recuperação de áreas degradadas.

A vegetação constitui-se num importante fator de controle da erosão, porque se apresenta como barreira física ao transporte de material, proporciona uma estrutura mais sólida ao solo devido ao sistema radicular, amortece o impacto das chuvas e ventos e eleva a porosidade da superfície, além de ser um método capaz de recompor a paisagem perturbada, ameniza o impacto visual, e reinicia a cadeia de sucessão biológica local (IBRAM, 1987; IBAMA, 1990).

No entanto, para a recuperação funcional de uma área degradada, não basta introduzir novamente a vegetação; envolvem-se ações como a modificação do solo e a reimplantação da fauna, seja para fins de preservação ou para uso em outras atividades econômicas (IBAMA, op.Cit.).

Com a regulamentação do PRAD e em cumprimento à legislação vigente, toda atividade com potencial de degradação deve ser devidamente licenciada pelos órgãos ambientais competentes. Para que o licenciamento ambiental seja concedido, a empresa deve desenvolver um processo de acompanhamento sistemático das conseqüências ambientais da atividade e desenvolver práticas rotineiras para um adequado monitoramento ambiental, sabendo que este é um instrumento de gestão ambiental que deve ser utilizado na mineração (BRANDI, 1994; SÁNCHEZ, 1993; SÁNCHEZ, 1994).

Pretendendo cumprir os objetivos do PRAD, é relevante a adoção de vistorias e inspeções periódicas, sendo que a eficácia das medidas adotadas deve ser monitorada 
através de indicadores ambientais de desempenho, para verificar os resultados e reformular, se necessário, o PRAD original (BITAR, 1997).

DIAS (2001) insere o monitoramento ambiental como forma de acompanhamento da AIA. Além disso, recomenda que as atividades de monitoramento sejam iniciadas desde a realização do Estudo de Impacto Ambiental (EIA), permitindo uma comparação futura da área afetada pelo empreendimento, de modo que as informações obtidas pelo monitoramento venham a fundamentar alterações no gerenciamento ambiental.

Estudos de impactos ambientais completos incluem a definição de um plano de monitoramento com localização dos pontos de amostragem, parâmetros a serem monitorados, métodos de análises e periodicidade.

Segundo FOWLER (1998), a definição dos critérios para a recuperação ambiental de áreas degradadas depende de estudos ecológicos. Uma das metas da chamada ecologia de recuperação é encontrar meio simplificado, de baixo custo e de fácil execução, para avaliar o desenvolvimento e a eficácia do processo. Um desses meios é a utilização de bioindicadores, ou seja, fatores ambientais que possam refletir adequadamente as condições do habitat de estudo.

Com base em estudos prévios sobre os bioindicadores adequados para cada caso, medições bastante simples permitem estimar com razoável precisão os níveis de recuperação ambiental. Fatores deste tipo podem ser encontrados na fauna, de tal forma que o retorno de diversos animais à áreas em recuperação se dá gradativamente, sendo que o único problema é a falta de maior contribuição científica nesta área, como acontece no Brasil. Alguns organismos podem ter grande utilidade como bioindicadores, tal qual é o caso dos invertebrados que possuem papel de destaque no processo de recuperação de um ecossistema (MAJER, 1989).

O levantamento das espécies de invertebrados é de extrema importância em relatórios de impacto ambiental, por ser um componente considerável no ecossistema, e de fácil captura. Por se tratar de um grupo que ocupa diversos níveis na cadeia trófica, os invertebrados são eficazes para predizer qualquer nível de alteração ambiental (MAJER, 1983). Estes são atuantes em várias áreas funcionalmente relevantes numa recuperação de ecossistemas e regularmente fornecem uma indicação 
mais sensitiva, complementando o papel da vegetação existente no local (JAMES; EVISON, 1979; GREENSLADE; GREENSLADE, 1984).

\subsection{RECUPERAÇÃO DE ÁREAS DEGRADADAS PELA MINERAÇÃO}

Segundo o manual de recuperação de áreas degradadas elaborado pelo Instituto Brasileiro do Meio Ambiente e dos Recursos Naturais Renováveis (IBAMA - 1990 p.13), a degradação de uma área ocorre assim que há perda de suas características físicas, químicas e biológicas, inviabilizando o desenvolvimento socioeconômico, a saber, que a degradação ocorre quando "a vegetação e a fauna nativas forem destruídas, removidas ou expulsas; a camada fértil do solo for perdida, removida ou enterrada; e a qualidade e regime de vazão do sistema hídrico forem alterados”.

É fato que o montante de áreas degradadas na Terra vem, dia após dia, expandindo-se de forma assustadora. Segundo JESUS (1994), apesar de a degradação ambiental ser um processo que pode ocorrer naturalmente ao longo do tempo, o agravamento e a aceleração deste processo ocorrem sempre em decorrência da ação antrópica, com atitudes inadequadas sobre os recursos naturais. Devido a este fator e tendo em vista a legislação ambiental, após a Constituição de 1988, a questão ambiental vem sendo enfatizada com maior rigor e esta preocupação atual com o meio ambiente tem destacado a recuperação de áreas degradadas (SEITZ, 1994).

A recuperação de áreas degradadas pode ser conceituada como um conjunto de ações idealizadas e executadas por especialistas das mais diferentes áreas de conhecimento, os quais visam a proporcionar o restabelecimento de condições de equilíbrio e sustentabilidade existentes anteriormente em um sistema natural (DIAS; GRIFFITH, 1998).

No entanto, a maioria das empresas responsáveis por esse tipo de alteração ambiental continua à espera de novas descobertas de condições ideais ou resultados de pesquisas, para tomar alguma providência a fim de recuperar o dano causado. $A$ falta de atitude acaba acarretando impacto significativo como a perda da 
biodiversidade, a diminuição de terras produtivas, sem contar a perda da qualidade de vida e dos freqüentes desastres ambientais de impactação extremamente negativa ao bem-estar da sociedade.

Dentre as diversas ações capazes de alterar as características ambientais, encontramos as atividades de mineradoras, fonte de riquezas há vários séculos e que hoje representam uma base importante na economia nacional (IBRAM, 1992), posto que apresentam um grau de impacto ambiental de alta magnitude, devido às modificações físicas e bióticas provocadas nas áreas de influência direta e indireta do projeto da indústria mineral.

O processo de recuperação de áreas degradadas é bastante lento, devendo ser iniciado desde a fase de planejamento do projeto minerário e finalizado muito tempo após o término da lavra, quando as relações entre os componentes bióticos e o ambiente apresentarem condições de equilíbrio e auto-sustentabilidade (BARTH, 1989).

Ao planejar o trabalho de recuperação é necessário considerar as peculiaridades e o histórico da área a ser recuperada. Aspectos relacionados aos diagnósticos efetuados nos estudos ambientais pré-mineração (EIA/RIMA) identificam as características específicas de cada mina e do local onde ela está implantada.

Estas características dizem respeito a aspectos biológicos, como a composição da flora e da fauna original; aspectos físicos, como relevo, clima etc; e aos aspectos socioeconômicos da região. Após avaliação dessas características e do dimensionamento do grau de importância em que os diversos efeitos ambientais ocorrerão, deve-se passar à definição e à hierarquização das medidas que devem ser executadas, definindo-se os objetivos pretendidos, ou seja, metas a serem cumpridas em uma escala temporal de curto, médio e longo prazos, com base no plano de recuperação do empreendimento (IBRAM, 1987).

Grande parte das empresas tem optado por metodologias mais práticas, pois visam a obter rápido resultado na recuperação das áreas. Tais métodos consistem na revegetação da área, com espécies resistentes e de rápido crescimento, sem levar em consideração os aspectos ecológicos fundamentais, como a biodiversidade e a sustentabilidade dos plantios. 
Gradativamente, um percentual dessas minerações, talvez pelo insucesso das técnicas previamente adotadas, percebeu ser insuficiente, para atingir resultados satisfatórios, seguir as mesmas técnicas de revegetação que outras empresas já vinham desenvolvendo, como se fosse uma receita a ser seguida por todos, indiscriminadamente.

A partir dessa percepção, as minerações passaram a avaliar e a estudar outras técnicas com abordagens mais ecológicas que pudessem a médio e longo prazos, melhorar os resultados biológicos e reduzir os custos de implantação da recuperação ambiental (GRIFFITH, 1992).

A crescente demanda por projetos capazes de estabilizar e recompor áreas degradadas fez surgir métodos aperfeiçoados de recuperação (BOWLES; WHELAN, 1994; JORDAN III; GILPIN; ABER, 1992). Assim, os métodos empregados largamente em cumprimento ao objetivo pré-determinado pelo empreendimento vão desde o simples recobrimento de taludes com gramíneas, formação de maciços puros de leucena, à consorciação de poucas ou muitas espécies nativas ou exóticas.

Segundo GRIFFITH (1980), é relevante que o objetivo da recuperação de uma determinada área degradada seja bem estipulado, de forma a se adotarem técnicas mais adequadas. Em função de um objetivo pré-definido, as técnicas de revegetação podem assumir diferentes funções, de acordo com a situação encontrada, podendo ser um elemento bastante eficaz de atuação e utilização nos programas de recuperação de áreas degradadas (FONSECA, 1989). Além do objetivo, antes de iniciar qualquer processo, também é importante a avaliação das causas da degradação e do grau de comprometimento do meio ambiente natural (SEITZ, 1996).

Convém considerar o objetivo da implantação de um controle ambiental, isto é, a definição dos termos "recuperação", "reabilitação" e "restauração" ambiental, que, segundo DIAS e GRIFFITH (1998), por se tratar de um assunto bastante recente e envolver diferentes áreas de conhecimento, muitas vezes são utilizados como sinônimos de um único processo de recuperação. Embora o mais considerável seja a implantação do processo, a definição destes três termos subsidia os profissionais que tenham interesse no assunto, tornando possível a escolha de um termo que melhor 
defina o processo empregado, facilitando assim a comunicação entre os pesquisadores interessados.

Muitos autores definem de forma diferente o termo "recuperação", o que torna ainda mais confusa a escolha de um termo específico. No manual elaborado pelo IBAMA (1990), recuperar significa retornar o ambiente degradado a uma forma e utilização de acordo com o objetivo preestabelecido para o uso do solo, o que implica a obtenção de uma condição estável, ou seja, condições mínimas para restabelecer um novo equilíbrio dinâmico, a fim de desenvolver uma nova paisagem.

O processo de recuperação deve sempre estar em conformidade com os valores ambientais, estéticos e sociais da circunvizinhança. A generalidade do termo recuperar também é enfatizada por SÁNCHEZ (1995), definindo-o como uma forma de encontrar um novo uso produtivo para uma determinada área perturbada, que pode ser igual ou diferente do uso pré-mineração; devendo apresentar um equilíbrio dinâmico com a circunvizinhança.

GRIFFITH (1986) procura sintetizar e definir o processo de recuperar como a reparação dos recursos a tal ponto, que seja suficiente para o restabelecimento da composição e freqüência das espécies originalmente encontradas no local. Já para MAJER (1989), o termo recuperar define-se num conceito mais genérico, atendendo a todos os aspectos para qualquer processo que vise a obtenção de uma nova utilização para a área degradada, envolvendo um planejamento, trabalhos de engenharia e processos biológicos. E a normalização técnica brasileira sintetiza o conceito de recuperação como um processo de manejo do solo onde são criadas condições adequadas a novos usos, seja a área natural ou perturbada, devolvendo o equilíbrio dos processos ambientais atuantes anteriormente (ABNT, 1989).

O termo "reabilitação" é definido por MAJER (1989), como o retorno da área a um estado biológico apropriado; o que pode significar seu uso produtivo em longo prazo, como a implantação de uma atividade que renderá lucros, ou então atividades que visam à recreação e ainda à valorização estético-ecológica. Existindo assim, a reabilitação condicional, a qual requer uma forma de manejo; e a reabilitação autosustentável, a que este manejo deve ser aplicado até o início do estabelecimento de um 
equilíbrio ambiental, a saber, uma floresta com vegetação nativa, própria à manutenção da vida selvagem.

A normalização brasileira definiu a reabilitação do solo como uma forma de recuperação, onde a área deve ser adequada a um uso determinado, segundo um projeto prévio, como, por exemplo, de uso comerciais, industriais, habitacionais, agrícolas etc. (ABNT, 1989).

Já em relação ao termo "restauração", embora considerado por DOWN e STOCKS (1977), IBAMA. (1990) e a ABNT (1989), como apropriado ao contexto de mineração, o definem como o retorno ao estado original, anterior ao início da atividade degradante, o que torna este termo impróprio para explicar os processos que normalmente são executados, por se tratar de uma situação muito rara ou até impossível de ser conseguida.

Tendo em vista as definições supracitadas, os termos mais indicados e que serão apresentados neste trabalho são recuperação e reabilitação de áreas degradadas. Reabilitar será utilizado para um processo que visa a uma nova utilização para a área degradada, para atingir certa estabilidade, sem que seja necessário o restabelecimento de característica semelhante à encontrada originalmente; e recuperar será utilizado para um processo que visa ao emprego de manejo para o retorno da área a um estado biológico apropriado, pretendendo-se atingir características semelhantes ao ambiente original.

Os procedimentos e atividades que compõem a recuperação de áreas degradadas pela indústria mineral devem incluir várias etapas, que podem variar de acordo com cada caso e experiência realizada. Segundo BITAR (1997), de uma maneira geral, a primeira atividade, qualquer que seja o trabalho de recuperação ambiental, deve identificar e caracterizar os processos de degradação atuantes e a análise de suas conseqüências ambientais e, a partir desta avaliação inicial, destaca-se basicamente o planejamento de como recuperar, executar o plano de recuperação elaborado e realizar o monitoramento e a manutenção das medidas executadas.

Ao planejar como recuperar uma área degradada por meio de revegetação devem-se estabelecer os objetivos do uso futuro da área e elaborar um plano de recuperação, (IBAMA, 1990). Este plano, porém, deve ser precedido pelo 
estabelecimento de um compromisso por parte do empreendedor de acordo com o processo de recuperação (BARTH, 1989).

CANADA (1995) prioriza alguns itens, como objetivos da recuperação de áreas mineradas, que devem ser executados com a participação da empresa, da comunidade envolvida e do órgão ambiental responsável. A maior importância é dada à proteção da saúde e segurança da comunidade, seguida do ato de minimizar ou até mesmo eliminar o passivo ambiental, definido por SÁNCHEZ (2001) como o acúmulo de danos ambientais que devem ser mitigados para que a qualidade ambiental de uma área degradada seja mantida e, por fim, garantir a produtividade local de modo similar ao original ou uma alternativa aceitável.

Para satisfazer tais condições, é indispensável que o local esteja em adequadas condições de estabilidade física e química, protegida dos impactos ambientais negativos que podem ser gerados nas atividades de lavra e beneficiamento, garantindo o uso futuro da área.

BITAR (1997, p.36) descreve resumidamente, os seguintes procedimentos básicos que devem ser executados, a partir da identificação e avaliação inicial do planejamento da recuperação de uma área degradada:

- estabelecimento do compromisso do empreendedor;

- avaliação detalhada da área degradada onde são identificados os processos de degradação frente aos impactos ambientais existentes e a definição de indicadores ambientais;

- definição dos objetivos da recuperação, estabelecendo metas a serem alcançadas a curto e médio prazos e a definição do uso pós-mineração;

- elaboração de um projeto de recuperação, compreendendo a escolha dos melhores métodos e técnicas a serem utilizadas, descrição dos procedimentos e medidas a serem adotadas, formulação de um programa de monitoramento e manutenção das medidas implementadas, análise do uso pósmineração frente a outras alternativas de uso futuro da área, estabelecimento de um cronograma dos trabalhos e previsão dos recursos humanos, materiais e financeiros que serão necessários.

Para efetivar a recuperação de uma área degradada é necessário o estabelecimento de técnicas definidas de acordo com os indicadores e parâmetros ambientais pré-avaliados. A escolha da melhor técnica de recuperação exige análises detalhadas para avaliar a eficácia das medidas, a fim de estabilizar a degradação ambiental. Dentre as alternativas aplicadas para recuperação de áreas degradadas, 
destaca-se o processo de revegetação, que visa à estabilidade biológica do ambiente; o processo geotecnológico que almeja à estabilidade física; e o processo de remediação que visa à estabilidade química do ambiente; sendo que na prática, tais medidas são aplicadas de modo combinado, sempre que necessário (BITAR; BRAGA, 1995).

\subsection{REVEGETAÇÃO}

Dentre os procedimentos básicos aplicados para a execução no processo de recuperação em áreas degradadas por mineração, pesquisadores do IBAMA (1990) desenvolveram um manual apresentando várias técnicas aplicáveis e propuseram uma seqüência de atividades para este processo: preparo da área a ser minerada, envolvendo planejamento e obras de drenagem na área a ser lavrada e remoção da cobertura vegetal (aproveitamento da biomassa), decapeamento e abertura da cava (armazenamento da camada fértil do solo e deposição de estéril), lavra e beneficiamento, recomposição topográfica e paisagística (preenchimento da cava com estéril, rejeito e solo), trato da superfície final (colocação da camada fértil do solo, descompactação e correção da fertilidade); controle da erosão, revegetação (preparo do solo, seleção de espécies, plantio ou semeadura); manutenção, monitoramento e uso futuro do solo.

Segundo IBRAM (1992), ao planejar o trabalho de recuperação, deve-se considerar os diagnósticos efetuados nos estudos ambientais que identificam as características da mina e do local onde ela está instalada. Tais características englobam os aspectos físicos, biológicos e sócioeconômicos da região. Com base nestes dados é possível estabelecer uma relação temporal para as ações corretivas ou mitigadoras, relacionando cada processo envolvido em determinados períodos a curto, médio e longo prazos, conforme podemos observar na Quadro 1. 


\begin{tabular}{|c|l|}
\hline Período aplicativo & \multicolumn{1}{c}{ Processos envolvidos } \\
\hline A curto prazo & - recomposição da topografia do terreno; \\
& - controle da erosão do solo; \\
& - revegetação do solo; \\
& - amenização do impacto na paisagem; \\
& - controle da deposição de estéreis e rejeitos. \\
\hline A médio prazo & - surgimento do processo de sucessão vegetal; \\
& - reestruturação das propriedades físicas e químicas do solo; \\
& - ocorrência de reciclagem dos nutrientes; \\
& - reaparecimento da fauna. \\
\hline A longo prazo & - auto-sustentação do processo de recuperação; \\
& - inter-relacionamento dinâmico entre solo-planta-animal; \\
& - utilização futura da área.
\end{tabular}

Fonte: IBRAM, 1992.

Quadro 1 - Períodos e processos envolvidos nas etapas de recuperação ambiental.

Diante dos distúrbios causados pela mineração, AUSTRÁLIA (1995, apud OLIVEIRA JR., 2001, p. 11), selecionou 14 princípios básicos que podem ser seguidos no processo de recuperação de áreas degradadas:

1. Preparar a recuperação por meio de planos no início da mineração; é necessário um plano prévio e dinâmico o suficiente, para ser aperfeiçoado ou modificado durante a vida da mina;

2. Sempre que possível, minimizar as áreas que devem ser desmatadas, quanto menos áreas desmatadas menor a quantidade de áreas a serem recuperadas;

3. Caracterizar e estocar o solo fértil para uso futuro, evitando assim o decapeamento de outros locais para a coleta destes solos;

4. Recuperar progressivamente a área à medida que a lavra avança, diminuir a quantidade de áreas a serem recuperadas da mina e os seus custos de recuperação, quando da desativação da mina;

5. Reconformar as áreas lavradas, tornando-as estáveis, drenadas e adequadas para o uso futuro do solo;

6. Minimizar, sempre que possível, os impactos visuais causados pela mineração, isso pode ocorrer através da recuperação simultânea à lavra e instalação de cortinas arbóreas no entorno da mina;

7. Após a lavra, reinstalar drenagens naturais existentes anteriormente, sempre que possível;

8. Minimizar a erosão eólica e hídrica após o fechamento da mina, por meio de revegetação e instalação de drenagens naturais;

9. Remover e controlar os materiais tóxicos e residuais, controlando o transporte, utilização e despejo de resíduos tóxicos; 
10. Preparar o solo após a lavra para permitir infiltração de ar, água e o crescimento da raiz, necessidade de descompactação do solo lavrado para permitir a instalação da vegetação;

11. Enriquecer o solo pobre em nutrientes com o uso de corretivos e adubos químicos ou orgânicos;

12. Revegetar a área minerada com espécies consistentes com o uso do solo após o fechamento da mina;

13. Prevenir o avanço de ervas daninhas e pragas nas áreas recuperadas, para evitar trabalho de replantio e perda de espécies;

14. Monitorar e gerenciar as áreas recuperadas até a vegetação tornar-se auto-sustentável em completa integração da área reabilitada às áreas circunvizinhas.

Seguindo o manual desenvolvido pelo IBAMA (1990), o primeiro passo que deve ser planejado é a questão do preparo da área a ser minerada. Nesta fase, é necessária a implantação de obras de drenagem com o objetivo de desviar as águas superficiais (pluviométricas e de mananciais) das áreas que serão lavradas. Nesta etapa, insere-se também a remoção da cobertura vegetal, a qual, sempre que possível, deve ser planejada de acordo com o avanço da lavra e processada de forma seqüenciada, sendo que apenas a faixa de vegetação necessária deve ser removida.

OLIVEIRA JR. (2001) ainda complementa que a área a ser desmatada deve ser sempre a mínima necessária à operação segura da mina e, quando possível, a vegetação retirada deve ser destinada a um uso específico, quer seja para lenha, móveis e utensílios em geral, e/ou ainda utilizada ao longo do processo de revegetação como fonte de sementes, proteção do solo contra erosão ou até mesmo como habitat natural para a fauna da região.

Após a remoção da vegetação, a primeira camada de solo - a qual concentra os maiores teores de matéria orgânica, micro e mesofauna do solo e nutrientes minerais deve ser removida e, se necessário, estocada em condições adequadas, em depósitos previamente e adequadamente projetados, de forma a não comprometer a qualidade deste solo. Sendo possível, a utilização imediata constitui-se na forma ideal de procedimento a ser seguido, pois todas as características físico-químicas e biológicas do solo podem ser aproveitadas de forma integral, beneficiando o desenvolvimento do vegetal a ser plantado (IBAMA, 1990; OLIVEIRA JR., op.Cit.).

Além das informações acima, SÁNCHEZ (2000) complementa que a conservação do solo é fundamental para o sucesso das atividades de recuperação, devendo ser 
removida separadamente e, estocada e armazenada por períodos de até dois a três anos.

Segundo AUSTRÁLIA (1995, apud OLIVEIRA JR., 2001), quando a necessidade de estocagem do solo fértil for inevitável, algumas regras devem ser seguidas como: a pilha de estocagem não deve ultrapassar 2,0 metros de altura; técnicas de revegetação devem ser aplicadas nestas pilhas mantendo os micronutrientes ativos do solo, evitar a erosão e o aparecimento de ervas daninhas; e sua localização deve ser fora da área de operação da mina, evitando-se o manuseio excessivo que possa causar efeitos adversos na estrutura do solo. Caso o solo fértil retirado se torne inviável, deve ser substituído por outro tipo de substrato similar (IBAMA, 1990).

O passo seguinte consiste na destinação do estéril e dos rejeitos do processo de beneficiamento. Sempre que possível este deve ser devolvido ao ambiente, visando o preenchimento da área já lavrada. O estéril e os rejeitos com componentes contaminantes devem ficar isolados, evitando a contaminação do ambiente. Somente após tratamento de descontaminação é que devem ser destinados ao preenchimento da área já lavrada. Caso não seja possível este tipo de destinação, todo o estéril e os rejeitos deverão ser armazenados em depósitos a seco (IBAMA, op. Cit.).

Ao destinar o estéril e os rejeitos para o preenchimento da cava, deve-se visar à modelagem e à remodelagem do relevo, principalmente se o objetivo da recuperação for a recomposição do ambiente anteriormente encontrado. Esta etapa deve ser elaborada por meio de recomposição da topografia e do paisagismo para que a composição estética do ambiente se torne harmoniosa e agradável à percepção humana (IBAMA, op. Cit.).

Segundo IBRAM (1992), em alguns casos, quando se executa o preenchimento da cava minerada a céu aberto, de forma controlada, pode-se obter uma recomposição da topografia com características muito semelhantes às originais e/ou muitas vezes até mais interessantes do ponto de vista estético, diante da capacidade da mineração, em modificar as paisagens. Em outros casos, não existe a possibilidade de preenchimento da cava minerada, como por exemplo, as pedreiras e exploração de ferro, devido a características geológicas como grau e direções de sistemas de fraturamento. KOPEZINSKI (1998) salienta, quanto ao preenchimento da cava, que o relevo final do 
terreno deve proporcionar melhorias na paisagem, estabilização de solos e taludes, controlar processos erosivos e possibilitar o uso futuro pretendido.

Para as áreas destinadas a revegetação, a etapa seguinte é a de tratamento da superfície final através da recolocação da camada fértil do solo, seguido de um procedimento que vise à adequada implantação em toda a área de uma camada de solo uniforme, obedecendo à conformação topográfica.

O controle da erosão, nesta fase do processo, é importante e para isso, devem-se implantar técnicas adequadas e eficientes buscando às necessárias construções de bancadas em patamares e/ou bermas, de acordo com a declividade presente na área, atendendo às exigências para um adequado sistema de drenagem. Em alguns casos, é recomendável a construção de pequenos tanques ou bacias de decantação ao longo do sistema de drenagem (IBAMA, 1990).

Segundo IBRAM (1992), a espessura da camada de solo deve estar de acordo com as características geomorfológicas locais e com o volume disponível de cada frente de lavra e, quanto maior a espessura desta camada mais eficiente será o recondicionamento vegetal.

Considerando-se o processo de revegetação como uma das etapas da estratégia de recuperação de áreas degradadas, SOUZA (1997) descreve a importância do conhecimento de fatores químicos, físicos e biológicos do solo, para o plantio de espécies adaptadas às condições adversas, tendo em vista a recuperação do substrato que acaba acelerando o processo de sucessão.

A descompactação do solo deve ser considerada, evitando-se prejudicar o desenvolvimento das raízes das plantas utilizadas, diminuindo o escoamento superficial e proporcionando a infiltração de água de chuva no solo, evitando a ação erosiva. Normalmente, os solos com alto grau de compactação apresentam textura argilosa (IBRAM, 1992; KOPEZINSKI, 1998); já os solos arenosos possuem problemas com infiltração intensa das águas, os quais acabam ocasionando a perda de nutrientes por lixiviação, com grande tendência à erosão intensiva (FONTES, 1991; apud KOPEZINSKI, 1998). Também a correção da fertilidade do solo deve ser adaptada, constituindo um grande desafio, pretendendo atingir um ideal necessário ao desenvolvimento das plantas (IBAMA, 1990). 
Nem sempre é possível manter a semelhança com o relevo anterior, dependendo do porte da degradação, como o caso de minas a céu aberto de grandes dimensões. Embora, na maioria das minas, as áreas a serem revegetadas se apresentem em bermas e taludes, resultantes da remoção de material ou de sua disposição em pilhas, dando um aspecto geométrico ao relevo final, isto não precisa ser aceito como forma definitiva do terreno.

Há situações onde é possível remodelar o relevo final de uma mina, de forma a reduzir o impacto visual da área a ser recuperada e até mesmo tentarem reproduzir formas de relevo dominante do entorno, com a suavização dos taludes e a criação de reentrâncias e sulcos, o que possibilita menor insolação e maior umidade, favorecendo o estabelecimento de comunidades vegetais adaptadas a esse ambiente.

O planejamento das bancadas da mina, taludes de pilha de estéril, cortes de estradas e demais intervenções no terreno devem ser realizados em conformidade com a compatibilidade hídrica de áreas vizinhas e estabilidade dos taludes, buscando atender o objetivo do uso futuro da área, estabelecido na fase de elaboração do projeto (SÁNCHEZ, 2000).

Após a correta preparação e correção do solo, é necessário escolher o tipo de vegetação mais adequado a ser adotado, sempre visando a atender os objetivos já estabelecidos para a recuperação. Nessa fase, a escolha correta da espécie a ser plantada é fundamental, visto que a revegetação é a principal prática para se obter a formação de um novo solo, controlar a erosão, evitar a poluição das águas e, se for o caso, promover o retorno da vida selvagem (IBAMA, 1990).

As técnicas que utilizam espécies vegetais de rápido crescimento nem sempre são as ideais e acabam atendendo parcialmente às expectativas do empreendedor. Claro que este fato depende muito dos objetivos propostos para a revegetação, os quais podem ser desde um simples plantio homogêneo de espécies arbóreas exóticas, aspirando a um reflorestamento comercial - aceitável apenas em áreas anteriormente não ocupadas por matas nativas - até um plantio heterogêneo de espécies nativas em áreas degradadas, anteriormente ocupadas por matas nativas. (GANDOLFI; RODRIGUES, 1996). 
O plantio heterogêneo de espécies nativas, apesar de não apresentar como resultado uma rápida melhoria do impacto visual como o plantio de espécies exóticas, é considerada, ecologicamente, a melhor prática. Há casos, dependendo da localização do empreendimento, em que a mata degradada destina-se à urbanização, não sendo necessária, neste caso, a implantação de técnicas de revegetação (IBAMA, 1990).

Os avanços significativos nas práticas desenvolvidas na revegetação de áreas degradadas por mineração no país, nos últimos anos, tanto no uso de espécies nativas como de exóticas tem sido reconhecido por alguns autores (GRIFFITH; DIAS; JUCKSCH, 1994; GRIFFITH; DIAS; JUCKSCH, 1996), os quais constatam a busca pela melhoria destas práticas, mas não garante, a longo prazo, o sucesso da revegetação, conforme já observado por BARTH (1989).

Assim, GRIFFITH; DIAS e JUCKSCH, (1996), embora reconheçam a relevância de trabalhos com espécies exóticas, propõem um modelo bioeconômico, com a introdução de espécies com rápido crescimento em locais degradados e preparados para receber, posteriormente, espécies nativas da região, além de considerar a manipulação da dinâmica de sucessão a fim de alcançar a auto-sustentabilidade da paisagem, de acordo com o uso da terra previsto no programa de recuperação de área degradada.

Dessa forma, deve-se escolher o melhor procedimento de seleção e plantio a ser utilizado na revegetação. A utilização de serapilheira - constituída por folhas, caules, ramos, frutos, flores, entre outras partes das plantas, bem como restos animais e material fecal - é um procedimento que pode ser bastante eficaz, dependendo da extensão da área a ser recuperada, por fornecer nutrientes que são absorvidos pelas plantas (SOUZA, 1997).

A serapilheira contém um verdadeiro banco genético de sementes com várias espécies presentes no ambiente natural. Sua aplicação em pequenas áreas protegerá a superfície de raios solares, conservando a umidade do solo; além de fornecer micro e mesofauna ao solo e sementes de plantas que são transportadas juntamente com a serapilheira coletada, proporcionando condições de desenvolvimento eficaz da flora e fauna (IBAMA, 1990).

$\mathrm{Na}$ ausência de serapilheira o processo de revegetação deve ser iniciado com introdução de espécies herbáceas, por meio de um plantio de diversas espécies de 
gramíneas e leguminosas. Estas serão utilizadas como adubos verdes, devido à capacidade de fixar nitrogênio, preparar o solo, permitir um bom crescimento das plantas e, ao mesmo tempo estabilidade do terreno, desencadeando um maior controle dos processos erosivos e o início de um processo de sucessão (IBAMA, 1990).

Deve-se ter o cuidado para não introduzir espécies herbáceas potencialmente invasoras, evitando-se problemas no equilíbrio ecológico da região e em áreas vizinhas. Ao mesmo tempo devem-se evitar espécies agressivas, ou sujeitas a incêndios, assim como as de grande porte e rápido crescimento, de forma a não prejudicar o desenvolvimento de espécies de menor porte, que possam estar presentes na área; permitindo assim, o início da sucessão natural (IBAMA, op. Cit.).

Para áreas originalmente cobertas por matas nativas, recomenda-se a implantação de espécies arbustivas e arbóreas nativas da região, priorizando, no início, espécies pioneiras com dispersão anemocórica e frutíferas nativas, possibilitando o aparecimento de insetos e aves capazes de disseminar as sementes (IBAMA, op. Cit.).

De acordo com o tamanho da área a ser recuperada, é recomendável a instalação de um viveiro de mudas no local para a produção de espécies nativas, por meio de coleta de plântulas e sementes de matas naturais da região, evitando o problema de fornecimento de mudas. Muitas vezes, para o cultivo de mudas a partir de plântulas e sementes coletadas diretamente das matas, torna-se necessário o uso de algumas técnicas adequadas que implicam um conhecimento minucioso das espécies que serão cultivadas, por exemplo, a quebra de dormência para antecipar a germinação das sementes utilizadas na produção das mudas, tornando possível controlar a produção de mudas de várias espécies de acordo com a época do plantio a ser realizado (IBAMA, 1990).

Segundo VASCONCELOS (2000), o melhor período para o plantio é determinado pela distribuição sazonal e pela precipitação pluviométrica. Após o plantio, é importante a manutenção adequada da área durante os primeiros anos, para garantir o sucesso de revegetação. Para tanto, é necessário o estabelecimento de critérios que visem ao acompanhamento do desenvolvimento das espécies, controle nutricional do solo, de doenças e pragas, entre outras medidas que devem ser estabelecidas de forma a favorecer o saudável crescimento das plantas (IBAMA, 1990). 
OLIVEIRA JR. (2001, p.28) também menciona a necessidade de monitoramento e gerenciamento após o processo de recuperação, sendo que o sucesso da revegetação pode ser comprometido pela invasão de predadores, ervas daninhas e atividades humanas. E sugere medidas de manutenção como: "replantio de áreas falhadas ou insatisfatórias, reparo de qualquer problema de erosão, gerenciamento de queimadas, controle de pestes e ervas daninhas; controle de predadores e animais nativos através do uso de cercas, aplicação de fertilizantes, controle de imigração e pH".

Levando-se em consideração que a capacidade produtiva e a sobrevivência de muitas espécies vegetais dependem diretamente das relações co-evolutivas com espécies animais, incluindo dispersores de sementes, polinizadores, protetores contra predadores, entre outras interações naturais, a fauna tem papel fundamental e deve ser considerada como um dos importantes componentes responsáveis pela configuração e manutenção da diversidade do ambiente. Assim, deve-se considerar o papel da fauna em programas de recuperação de áreas degradadas, de forma a manter a diversidade de espécies vegetais em sua reprodução e qualidade do solo, podendo ser algumas espécies utilizadas como bioindicadores da recuperação dos habitats (IBAMA, 1990).

Segundo OLIVEIRA JR. (2001), a fauna pode ser introduzida, como no caso de alguns invertebrados ou migradas de áreas vizinhas, sendo que a taxa de colonização da fauna é influenciada pelo alcance de fatores que incluem o tamanho da área recuperada, a população da fauna circunvizinha e o sucesso das técnicas adotadas no processo de revegetação.

O monitoramento da fauna deve ser iniciado, segundo IBAMA (1990), logo após o início do processo de revegetação, o que permite um acompanhamento das etapas de sucessão, com o resultado de levantamentos periódicos de invertebrados que permitam determinar e monitorar as espécies que ocorrerão no local.

Para o sucesso da instalação e atratividade da fauna, muitas vezes é essencial a implantação de algumas técnicas adaptativas do ambiente a ser recuperado (VIERT, 1988), disponibilizando uma maior diversidade de habitats, e fornecendo estruturas para abrigo, nidificação, pouso e alimentação para a micro, meso e macrofauna.

Em auxílio ao processo de recuperação ambiental, a macrofauna pode ser reintroduzida e se faz necessário o acompanhamento de suas interações com o 
ambiente e com os demais ocupantes, juntamente com a implantação de fiscalização de caça, uma vez que esta será presa fácil no ambiente em formação (IBAMA, 1990). 
CAPITULO 2

\section{MONITORAMENTO AMBIENTAL}

\subsection{O MONITORAMENTO AMBIENTAL NA MINERAÇÃO}

Considerado como um importante instrumento de gerenciamento ambiental utilizado pela indústria de mineração, o monitoramento ambiental consiste no acompanhamento contínuo e sistemático de variações temporais e espaciais dos parâmetros ou variáveis ambientais, ao longo e após a vida útil dos projetos (BRANDI, 1994; CAVALCANTI, 2002).

Com o objetivo de localizar, identificar e avaliar, qualitativamente e quantitativamente, as condições dos recursos naturais em um determinado local e momento, segundo OGLIARI (2005), o monitoramento ambiental leva em consideração não só as variáveis temporais e espaciais, mas também as variáveis sociais, econômicas e institucionais, uma vez que se trata de um instrumento de controle e avaliação dos fatores que possuem influência no estado de conservação, preservação, degradação e recuperação ambiental.

Visto que pode ser aplicado em empreendimentos em pleno funcionamento e permite avaliar e corrigir situações presentes e minimizar efeitos futuros, SÁNCHEZ (1994) o classifica como um instrumento de gerenciamento com caráter corretivo e preventivo. Como artifício de controle da qualidade ambiental em áreas submetidas a processos de lavra, incluindo suas adjacências, o monitoramento ambiental é considerado por BRANDI (op.Cit.) a forma mais eficaz de se garantir a qualidade do meio ambiente nas áreas de influência de uma mineração. 
A seleção das variáveis a serem monitoradas e os critérios de monitoramento baseados na significância, natureza e magnitude dos impactos são fatores que devem ser considerados na elaboração do plano de monitoramento ambiental, sendo constituídos como principal instrumento de apoio aos estudos de impacto ambiental usados pelas empresas de mineração. A detecção das fontes geradoras de poluição e o levantamento das características e propriedades do ambiente afetado constituem linhas-base para uma efetiva proposta de monitoramento (BRANDI, 1994).

O acompanhamento da implantação de todas as medidas que visam reduzir, eliminar ou compensar os impactos negativos ou potencializar os positivos, deve estar presente nas fases de planejamento, implantação, operação e desativação de um empreendimento, sendo que a aplicação de um programa de monitoramento deve permitir confirmar, ou não, as previsões feitas no estudo de impacto ambiental, averiguando a eficiência das medidas adotadas para atenuar os impactos negativos, e a recuperação ambiental já implantada, assim como as condições ambientais nas áreas de influência do projeto (SÁNCHEZ, 2004).

O estudo completo de impacto ambiental, referentes ao setor mineral inclui a definição de um programa de acompanhamento e monitoramento da qualidade ambiental, permitindo uma comparação futura da área afetada pelo empreendimento, após a sua implantação, de modo que as informações obtidas pelo monitoramento venham a fundamentar alterações no gerenciamento ambiental, possibilitando adaptações no projeto e nas medidas mitigadoras adotadas (DIAS, 2001).

No Brasil, o acompanhamento e monitoramento dos impactos ambientais constituem uma das atividades técnicas previstas nos estudos exigidos para 0 licenciamento ambiental, tais como: o Estudo de Impacto Ambiental e seu respectivo Relatório (EIA/RIMA), Plano de Controle Ambiental (PCA), Relatório de Controle Ambiental (RCA), Plano de Recuperação de Áreas Degradadas (PRAD) etc. O monitoramento ambiental é efetivado a partir do Programa de Acompanhamento e Monitoramento dos Impactos Ambientais contido no EIA/RIMA, aprovado pelo órgão de meio ambiente, por ocasião da emissão da licença ambiental (MUNNO, 2005).

Segundo DIAS (2001) e CAVALCANTI (2002), para o sucesso do monitoramento ambiental, como instrumento de gerenciamento, devem ser definidos, detalhadamente; 
os parâmetros ambientais relevantes a serem monitorados, a seleção de indicadores ambientais para a análise de tais parâmetros, a definição dos pontos de amostragem, o estabelecimento da freqüência de amostragem, a localização dos pontos e periodicidade, a escolha dos métodos de coletas e análises das amostras e a interpretação dos resultados. Estes processos, segundo MUNNO (2005), constituem a técnica disponível para a execução do Programa de Acompanhamento e Monitoramento dos Impactos Ambientais, sendo também utilizadas, em alguns casos, técnicas de acompanhamento temporal como o Sensoriamento Remoto (com a utilização de imagens de satélites de épocas diferentes) e o Biomonitoramento.

SÁNCHEZ (1993, p.130) enfatiza a importância que deve ser voltada para os métodos de obtenção e a validade dos dados necessários para a utilização do monitoramento ambiental como instrumento de gerenciamento, e levanta alguns pontos que deveriam ser questionados, como:

1. Os métodos de freqüência de amostragem estão satisfatórios?

2. Os métodos provaram ser satisfatórios em função da comparação dos resultados obtidos daquilo que era esperado?

3. As técnicas de preservação de amostras são seguidas à risca?

4. Os técnicos encarregados da obtenção e análise das amostras são suficientemente treinados?

5. Existem duplicatas dessas amostras, quando possível, para eventual verificação?

DIAS (2001) insere o monitoramento ambiental como uma forma de acompanhamento do processo de Avaliação de Impacto Ambiental (AIA), como um instrumento que fornece medidas pós-projeto; revela as alterações ocorridas e permite sua avaliação, de forma a retratar a evolução da qualidade ambiental das áreas submetidas a medidas mitigadoras dos impactos ambientais e processos de recuperação ambiental. O monitoramento ambiental utilizado como um instrumento de gerenciamento é capaz de trazer benefícios ambientais reais, buscando antecipar os efeitos que as ações potencialmente causadoras de impactos ambientais, préestabelecidas no processo de AIA, geram no meio ambiente.

O processo de AIA deve ser desenvolvido antes da implantação de ações causadoras de impactos, que geram incertezas, uma vez que tal ação é de fato estabelecida podem ocorrer impactos inesperados ou de magnitudes imprevistas, ineficiência das medidas mitigadoras programadas, alterações no próprio projeto que 
resulte em novas relações com o meio, além da possibilidade da não implantação das medidas atenuadoras definidas na aprovação do projeto (DIAS, op. Cit.).

O monitoramento, a ser aplicado no início de um projeto, busca verificar sua real execução, de acordo com os termos de aprovação, se as medidas mitigadoras correspondem às requeridas, e se as condições impostas para a aprovação do projeto foram alcançadas. Além disso, o monitoramento pode revelar a existência de impactos inesperados ou de magnitude não prevista, e acaba gerando informações importantes na avaliação do impacto ambiental de projetos ou ações similares (WOOD, 1995).

Os objetivos do monitoramento podem ser alcançados com a utilização de uma variedade de ferramentas definidas pela EPA - Environmental Protection Agency (MUNNO, 2005), as quais são determinadas por uma Inspeção, para determinar se os termos e condições do projeto estão sendo realizados; por um Monitoramento dos efeitos, através de medição para detectar mudanças dos parâmetros e verificar a efetividade das medidas mitigadoras durante a construção e/ou operação, que podem ser atribuídos ao projeto; pela Obediência ao plano de monitoramento; e pela Auditoria ambiental, que possibilita verificar a precisão das previsões do EIA, a efetividade das medidas atenuadoras e a obediência às exigências regulamentais, padrões e políticas internas ou aos limites ambientais. A auditoria ambiental pode ocorrer durante a realização do projeto ou depois que ele foi executado.

WOOD (1995) emprega o termo auditoria de impactos para designar a comparação entre os resultados de atividades de monitoramento com as previsões feitas dos compromissos assumidos em fases anteriores do processo de AIA. O propósito da auditoria ambiental é verificar a conformidade ou não do empreendimento em relação às condições de aprovação, e pode ser conduzida pela autoridade ambiental ou pelo proponente como parte de procedimentos de auditoria interna, ou ainda, por estudiosos da área.

A auditoria ambiental é considerada por BRANDI (1994), como um instrumento de apoio que auxilia no cumprimento dos objetivos traçados, atuando diretamente no controle da qualidade ambiental, reconhecendo os modelos de monitoramento utilizado pelas empresas. Portanto, o monitoramento ambiental demonstra sua importância por permitir o bom relacionamento da empresa com órgãos governamentais e com o 
público, facilitando a verificação sistemática da conformidade das operações quanto aos padrões e às normas estabelecidas (CAVALCANTI, 2002).

\subsection{MONITORAMENTO AMBIENTAL NA RECUPERAÇÃo DE ÁREAS REVEGETADAS}

O impacto provocado no solo, causado pela movimentação de materiais em minas a céu aberto, deve ser atenuado e monitorado. Um dos principais processos de mitigação, nestes casos, é a reconstituição do relevo, seguido de um adequado processo de revegetação (PRADO FILHO; SOUZA, 2002). O monitoramento das áreas degradadas, que passam por intervenções visando à recuperação ambiental por meio de técnicas de revegetação, constitui um conjunto de ações e procedimentos destinados a avaliar o sucesso e o avanço da recuperação destas áreas (ALMEIDA, 2002).

O monitoramento ambiental de áreas revegetadas deve ser desenvolvido por meio de acompanhamentos químico-físicos e biológicos do substrato, além da evolução da vegetação e da fauna. Estes acompanhamentos permitem verificar a eficiência da cobertura vegetal na proteção dos solos e refúgio da vida silvestre, considerando aspectos importantes como: a velocidade de crescimento da vegetação implantada, a avaliação da estrutura e da biodiversidade do novo ecossistema, e a verificação do próprio estado do solo (ALMEIDA, op. Cit.). Para que os objetivos do monitoramento de áreas revegetadas sejam alcançados, faz-se necessária a verificação e investigação, em longo prazo, da capacidade de sustentabilidade do novo ecossistema implantado (PRADO FILHO; SOUZA, 2002).

Segundo SÁNCHEZ (1993), os impactos sobre ecossistemas constituem um problema de gerenciamento ambiental na indústria de mineração. Por se tratar de atividades que exploram recursos naturais, a mineração, muitas vezes, se encontra diante de problemas do tipo desmatamento, sendo sua solução e o gerenciamento deste, bastante diferentes da solução e do gerenciamento de problemas de controle da 
poluição. Os impactos sobre os ecossistemas ocorrem na forma de destruição ou modificações de habitats, de limitação da disponibilidade de um ou mais recursos (energia solar, água, ou nutriente), ou da criação de diversos tipos de estresse (movimentação de pessoas e veículos, e emissão de poluentes). Entre as ações de gerenciamento de ecossistemas, SÁNCHEZ (1994) inclui a limitação das áreas a serem desmatadas, o manejo da fauna e a recuperação de habitats.

O aperfeiçoamento das técnicas de revegetação pode se dar com a utilização de indicadores de desempenho ambiental, pois geram informações referentes à evolução do processo, ao longo do tempo, permitem verificar se as metas delineadas estão sendo atingidas, possibilitando a avaliação necessária de eventuais ajustes para a recuperação obter sucesso (ALMEIDA, 2002). Tal verificação garante a possibilidade de efetuar novas avaliações da área degradada e executar reformulações, complementações ou até mesmo substituições (totais ou parciais) das medidas adotadas, em caso de eventuais resultados insatisfatórios (BITAR, 1997).

O desenvolvimento de métodos apropriados para o monitoramento ambiental, exige a escolha de parâmetros que possam ser empregados na avaliação da eficácia de um projeto de recuperação. Com essa finalidade, vários estudos já foram desenvolvidos e são citados por SIQUEIRA (2002), entre eles destacam-se os que demonstram modificação na estrutura de comunidades de micro, meso e macrofauna, estudos de diversidade e de dinâmica de populações, características físico-química e biológica do solo etc.

São comuns nos processos de monitoramento, os ensaios biológicos e físicoquímicos na verificação dos níveis de qualidade ambiental dos cursos d’águas, utilização de aparelhos de medição da poluição do ar, análise dos nutrientes do solo, $\mathrm{pH}$, e índice de diversidade da flora e fauna, tanto aquática como terrestre (BISSET, 1980).

Um grande percentual dos trabalhos de monitoramento ambiental de ecossistemas terrestres utiliza comunidades vegetais para a avaliação do sucesso da recuperação do habitat. Porém, o estudo de parâmetros estruturais da comunidade vegetal (riqueza, altura, diâmetro, densidade, diversidade, freqüência e área basal) não representa a totalidade dos objetivos pretendidos pela recuperação de áreas 
degradadas. Quando o objetivo é a auto-sustentabilidade, ou seja, o estágio no qual não exige a intervenção externa para que o sistema se mantenha, faz-se necessária a avaliação da retomada das funções ecológicas de um ecossistema (ex: ciclagem de nutrientes e fluxo de energia) (KOLKA; NELSON; TRETTIN, 2000).

Diferentemente dos aspectos estruturais que possuem uma escala pontual, ou seja, descrição do que está presente num determinado momento; as funções ecológicas são examinadas por meio de processos que ocorrem em escala temporal (GRAYSON; CHAPMAN; UNDERWOOD, 1999), e é a característica temporal que acaba por dificultar o monitoramento da funcionalidade de um ecossistema. Embora a estrutura (relacionada à diversidade) e a funcionalidade de um ecossistema possam estar correlacionadas, trata-se de aspectos distintos que não devem ser confundidos (PALMER; AMBROSE; POFF, 1997).

Os impactos causados pela mineração geram distúrbios no meio biológico e, para que a auto-sustentabilidade do sistema de recuperação seja alcançada, SÁNCHEZ (1996, apud DIAS, 2001) descreve alguns aspectos básicos de gerenciamento dos impactos da mineração no meio biológico que deveriam ser seguidos. Tais preceitos se iniciam na fase de estudo de base e englobam alguns tópicos principais:

- diagnóstico completo do ecossistema, na fase do estudo de impacto ambiental, com a execução de levantamentos adequados, incluindo mapeamento de biótopos e levantamento das espécies da vegetação e da fauna que devem ser devidamente registrados. Nesta fase, os indicadores ambientais devem ser escolhidos para posteriores monitoramentos;

- as áreas de desmatamento devem ser minimizadas e, sempre que possível, as áreas de preservação permanente devem ser mantidas intactas; deve-se também evitar a formação de pequenas ilhas de vegetação como formas de assegurar a viabilidade da fauna e corredores ecológicos devem ser elaborados para que áreas remanescentes de vegetação sobre influência direta da mina sejam interligadas com outras manchas de vegetação existentes nos arredores, permitindo a dispersão da fauna; além disto, o cronograma de desmatamento deve ser ajustado com o planejamento da lavra e a recuperação das áreas afetadas ou de áreas de compensação deve ser progressiva; 
- a recuperação de áreas degradadas deve ser realizada com a utilização preferencial de espécies nativas para a revegetação, sendo importantes a criação e manutenção de viveiros de mudas e a utilização de critérios ecológicos no processo da recuperação;

- áreas nas imediações da mina, com vegetação nativa, devem ser preservadas e áreas degradadas devem ser recuperadas e revegetadas, de maneira a compensar a remoção necessária da vegetação para o processo de lavra;

- os impactos e os resultados das ações de recuperação ambiental devem ser monitorados e registrados sistematicamente, possibilitando a verificação de eventuais falhas e imprevistos, e sua adequada reorientação;

- além da importância de se promover o desenvolvimento ativo de colaboradores e da comunidade, como meio de criar uma conscientização e educação ambiental, perante as atividades ambientais que estão sendo desenvolvidas.

O acompanhamento da etapa de sucessão do novo ecossistema implantado deve ser realizado logo após o início do processo de revegetação. O monitoramento da fauna evita o ataque de pragas nas plantas recém instaladas e a instalação de espécies oportunistas. Levantamentos periódicos são recomendados e possibilitam determinar quais espécies estão se estabelecendo na área e quais estão apenas explorando seus recursos (IBAMA, 1990).

O manejo da fauna, na fase operacional do processo de recuperação em áreas degradadas pela mineração, permite uma adequação do ambiente no sentido de suportar as comunidades animais e garantir uma estrutura faunística ideal.

O manual de recuperação de áreas degradadas (IBAMA, op.Cit.) enfatiza alguns aspectos importantes que devem ser considerados no manejo da fauna, como o adensamento de espécies vegetais nativas de interesse para fauna, ou seja, que fornecem alimentos (frutos, sementes, néctar, folhas, etc) e abrigo; e a reprodução de espécies em cativeiro, em casos especiais de áreas com espécies raras, endêmicas ou ameaçadas de extinção, e sua reintrodução no ambiente recuperado.

Animais atraídos ou reintroduzidos devem ser marcados e acompanhados para a verificação da adaptação desses ao novo ambiente, e um sistema de fiscalização de 
caça deve ser realizado, uma vez que esses animais tornam-se presas fáceis, no ambiente em formação.

Assim, visando auxiliar a recuperação da fauna, várias técnicas e seus principais benefícios (Quadro 2) foram descritos por VIERT (1988) e modificadas no manual de recuperação de áreas degradadas elaborado pelo IBAMA (1990): 


\section{Técnicas}

a) Remoldar a topografia, criando ondulações, relevo acidentado, depressões não drenadas na superfície e pequenos acidentes topográficos;

b) Remoldar os paredões e taludes altos de rocha remanescentes em pedreiras e cavas profundas, produzindo reentrâncias;

c) Instalar açudes;

d) Recolocar logo em seguida a camada fértil do solo em áreas já preparadas, espalhando-as em espessuras não uniformes;

e) Distribuir, aleatoriamente, bermas na área;

f) Distribuir na área: troncos, pedaços de madeira e galhos em pilhas;

g) Reconstruir leitos de cursos de águas e plantar espécies de mata ciliar;

h) Estabelecer faixas de vegetação densa, ligando a área recuperada com habitats naturais;

i) Instalar estruturas para abrigo, nidificação, pouso e alimentação da fauna.

\section{Benefícios}

a) Fornece diversidade do habitat, abrigo para esconderijo e proteção contra as intempéries, e condições para o desenvolvimento de elementos de uma biota variada;

b) Fornece condições de nidificação das aves de rapina que habitam esses ambientes;

c) Fornece habitat para animais aquáticos e fontes de água para a fauna em geral;

d) Favorece o estabelecimento da diversidade da flora, com sementes de espécies nativas e microorganismos do solo;

e) Fornece habitats para micro, meso e macrofauna do solo, assim como para pequenos vertebrados;

f) fornece micro-habitats e abrigos para a fauna alada e terrestre;

g) Devolve sistemas para a fauna que habita as margens dos cursos de água;

h) Cria corredores de ligação para o movimento da fauna entre habitats naturais;

i) Propicia o aumento das populações animais com a possibilidade de aumento na diversidade da fauna.

Fonte: VIERT, 1988; apud IBAMA, 1990.

Quadro 2 - Técnicas de recuperação da fauna.

Para que se tenha precisão de uma análise ou medição, é necessário determinar os limites de detecção dos procedimentos adotados e, para essa determinação duas 
possibilidades são possíveis de serem utilizadas como referência: por meio da determinação de uma área de pesquisa onde parte das estações experimentais se encontre fora de influência de emissões ou, pela determinação de pontos de controle localizados em áreas distantes, sem a influência direta do agente modificador do ambiente, porém com características bióticas e abióticas comparáveis (LIMA, 2000c).

$A$ avaliação de áreas recuperadas geralmente requer a comparação destas com outras de referência (PALMER; AMBROSE; POFF, 1997). Em muitos casos essas áreas não existem nas proximidades daquela a ser recuperada, em função da devastação das áreas florestadas, além da inexistência de históricos de degradação e estado de conservação das áreas remanescentes, impossibilitando a sua utilização como modelo (GRAYSON; CHAPMAN; UNDERWOOD, 1999).

A aplicação do monitoramento sistemático em áreas degradadas com o uso de indicadores, ao longo do tempo, gera dados que devem ser interpretados, analisados e utilizados em relatórios de monitoramento. Segundo ALMEIDA (2002) estes dados quando adequadamente interpretados acabam por facilitar o processo de avaliação dos resultados obtidos, ora conduzida por órgãos ambientais fiscalizadores, ora pelo próprio proponente do projeto, permitindo uma melhor noção do estágio de evolução de uma área revegetada.

\subsection{O USO DE INDICADORES NO MONITORAMENTO}

Tendo em vista a necessidade do monitoramento ambiental, empresa de mineração vem adotando esta prática como parte fundamental do sistema de gerenciamento ambiental do empreendimento, a fim de efetivar o acompanhamento de suas atividades (PRADO FILHO; SOUZA, 2002).

Pela busca em facilitar o desenvolvimento de um sistema que permita a avaliação da sustentabilidade de áreas, VAN BUEREN e BLOM (1997, apud MUNNO, 2005) indicam a necessidade da utilização de uma estrutura conceitual hierarquizada, com princípios, critérios e indicadores. Esta estrutura está baseada na idéia de que o 
monitoramento deve ser organizado de níveis superiores para inferiores, ou seja, por uma regra geral (princípios) que deve ser seguida como base de raciocínio e guia de ação; seguida por critérios, os quais se constituem por características que distinguem os aspectos a serem julgados; e finalizando com a escolha de indicadores, a saber, variáveis ou parâmetros que podem ser medidos com relação a um critério.

ALMEIDA (2002) entende indicador ambiental como um parâmetro ou conjunto de parâmetros que fornecem uma informação agregada e sintética sobre um fenômeno, e o define ao organismo, comunidade biológica ou parâmetro que serve como medida das condições ambientais de certa área ou de um ecossistema.

Seguindo os preceitos definidos por VAN BUEREN e BLOM (1997, apud MUNNO, 2005), o estudo de SIQUEIRA (2002) pode ser demonstrado como um exemplo, onde o princípio a ser julgado é a restauração das funções ecológicas de um habitat, tendo como critério o restabelecimento da dinâmica de sucessão da área e, utilizando como indicadores os organismos vegetais, nos quais são estudados o comportamento e composição das espécies, ao longo do tempo, em relação à quantificação e qualificação de bancos de sementes presentes no solo, chuva de sementes e o estrato de regeneração presentes na área de estudo.

POGGIANI; STAPE e GONÇALVES (1998) desenvolveram um estudo de indicadores de sustentabilidade de plantações florestais, e definiram como critério, aquilo que serve de base para julgamento, comparação ou apreciação sendo: a análise da variação da fitomassa acumulada ao longo do tempo, a sustentabilidade da produtividade biológica, estimativa do número de espécies de plantas ou animais existentes na área, impactos sobre as características do solo, entre outros exemplos de critérios que podem ser utilizados em programas de monitoramento de plantações florestais.

Em relação aos indicadores, os autores os definem como parâmetros ambientais (aspectos climáticos, edáficos, ecológicos, fenológicos, fisiológicos, etc) que podem ser registrados, organizados e avaliados repetidamente ao longo do tempo, permitindo o estabelecimento da relação causa e efeito entre o desenvolvimento vegetal e as características físicas, químicas e biológicas presentes no ambiente, citando como 
exemplo de indicador, a qualidade da água produzida em uma bacia hidrográfica em função das espécies arbóreas usadas no reflorestamento e das técnicas de manejo.

Em um programa de monitoramento ambiental podem ser observados $\mathrm{e}$ utilizados diversos parâmetros indicadores. LEWIS et al. (1995, apud POGGIANI; STAPE; GONÇALVES, 1998) citam diversos exemplos que podem ser utilizados como forma de monitoramento, entre eles: crescimento das árvores em altura, diâmetro e acúmulo de fitomassa, características da copa, densidade arbórea do povoamento, evolução da área basal, área foliar, macro e micronutrientes nas folhas, água no solo, matéria orgânica e fertilidade do solo e grau de compactação, produção de serapilheira e sua velocidade de decomposição, ataques de pragas, efeito de poluentes, diversidade da vegetação do sub-bosque, profundidade do lençol freático etc.

Em alguns casos, quando bem escolhidos, os indicadores ambientais dão base para que previsões, relacionadas à sustentabilidade dos ecossistemas, sejam feitas a médio e longo prazo, uma vez que também permitem estabelecer uma relação de causa e efeito das variáveis físicas, químicas e biológicas de um habitat (POGGIANI; STAPE; GONÇALVES, op.Cit).

Na maioria das vezes, a avaliação das condicionantes ambientais é realizada por meio de metodologias que empregam recursos químicos, físicos ou físico-químicos, os quais são realizados com o auxílio de técnicas específicas, utilizando tecnologias sofisticadas e caras que permitem quantificar o nível de perturbação ambiental, qualificando o ambiente. Como exemplo, podemos citar o controle de temperatura, $\mathrm{pH}$, turbidez, presença de elementos químicos de um corpo d'água, controle de ruídos numa área industrial, análise de solo etc (LIMA, 2000b).

O monitoramento biológico, desenvolvido na Europa, com enfoque na avaliação da poluição atmosférica, é uma metodologia que começa a despertar o interesse no Brasil, em pesquisas voltadas para a avaliação de impactos ambientais (LIMA, 2000a). O desenvolvimento na área do monitoramento biológico desencadeou o surgimento de muitos métodos e enfoques que se desenvolveram em conexões com diferentes linhas de pesquisa e aplicações práticas (LIMA, 2000c).

Avaliar a qualidade ambiental, por um período de tempo, com o auxílio de organismos vivos - biomonitoramento ambiental - é uma pratica relativamente nova nas 
ciências ambientais. Consiste na observação da reação funcional e comportamental de organismos vivos sensíveis, perante modificações e estímulos ambientais.

Enquanto no monitoramento físico-químico, abordam-se a qualidade e quantidade desses fatores, podendo eventualmente inferir sobre os efeitos biológicos; no biomonitoramento é possível obter-se informações sobre o efeito diretamente no sistema biológico, possibilitando inferir na qualidade e quantidade do fator de estresse. Assim, o estudo comportamental de determinados organismos pode dar indícios do nível de desenvolvimento de um ambiente em diferentes fases de reconstituição, os quais podem ser avaliados pelo comportamento e estrutura de determinadas espécies e/ou composição de espécies presentes em cada ambiente (LIMA, 2000a; LIMA, 2000c).

Basicamente existem dois tipos de organismos indicadores: "indicadores sensíveis" e "indicadores acumuladores". Ambos os indicadores podem ser encontrados entre os organismos testes, monitores e indicadores (LIMA, 2000a; LIMA, 2000c).

Os organismos testes utilizados em análises toxológicas do monitoramento da qualidade de corpos d'água e controle da qualidade atmosférica, são empregados em metodologias de laboratório, altamente padronizadas e produzem informações quantificáveis que nem sempre podem ser diretamente transferidos para o ecossistema.

Organismos testes animais são empregados normalmente para detectar riscos imediatos para a população humana; na avaliação de poluentes ambientais, como os pesticidas, e também no monitoramento e controle da poluição do ar, por meio de testes de toxidade que monitoram as taxas de germinação e/ou crescimento de partes aéreas e raízes de algumas espécies vegetais. Como exemplo de organismos testes pode-se citar as algas, os peixes, bactérias, algumas espécies de animais superiores, algumas espécies vegetais etc (LIMA, 2000a).

Os organismos monitores são utilizados em metodologias que monitoram condições ambientais e fornecem informações necessárias ao controle aplicado da poluição, especialmente da poluição do ar. Eles podem ser ativos, quando são introduzidos no ambiente, de forma padronizada; e passivos, quando se encontram presentes no ambiente, e passam a ser estudado a partir de procedimentos diretos ou de coleta de amostras, posteriormente analisadas em laboratórios. 
São exemplos de organismos monitores, dentre várias espécies vegetais, podem-se citar as gramíneas, normalmente utilizadas na avaliação de acúmulos de metais pesados; o tabaco que é empregado na avaliação do efeito do ozônio e os líquens que são utilizados para a determinação de efeitos fitotóxicos e no acúmulo de poluentes (LIMA, 2000c).

Os organismos indicadores (bioindicadores) são definidos como indicadores biológicos ou comunidades de indicadores que podem fornecer informações sobre as condições de um ecossistema (como por exemplo, na indicação de alterações no valor de $\mathrm{pH}$ ou concentrações de metais pesados no solo), visto que algumas espécies animais e vegetais sofrem alterações no tamanho e composição de suas comunidades, em respostas a alterações ambientais, causadas com o surgimento de poluentes (LIMA, 2000a).

Dentre os organismos indicadores, destacam-se os indicadores ecológicos que são utilizados quando se pretende avaliar as condições ou o comportamento do ecossistema como um todo. Estes fornecem informações sobre o estado de um habitat, no qual os organismos existem em condições naturais de competição.

Diferentemente dos organismos indicadores ecológicos, os organismos testes e os organismos monitores são capazes apenas de fornecer resultados auto-ecológicos, sendo que os efeitos observados não podem ser automaticamente transferidos para outros organismos ou para o ecossistema como um todo (LIMA, 2000b; LIMA, 2000c).

Os organismos mais utilizados em trabalhos de indicação e monitoramento ambiental de ecossistemas terrestres são os vegetais, pois, além de constituírem organismos fixos e serem numerosos, algumas espécies apresentam reações comportamentais visíveis e são capazes de acumular substâncias a serem monitoradas, tornando-se excelentes indicadores da situação ambiental (LIMA, 2000a).

Alguns organismos animais também podem ser utilizados como excelentes bioindicadores por serem capazes de evidenciar significativas mudanças ambientais. Podem ser citados os invertebrados, dentre eles a classe de insetos, mais especificamente as formigas (FOWLER, 1998).

Os indicadores ambientais, para serem amplamente utilizáveis e aplicáveis, devem possuir algumas características descritas por PRABHU et al. (1996), como 
seguem: devem ser relevantes à questão, estarem relacionados a um ou mais características a serem estudadas (critérios), e estas aos princípios; serem precisamente definidos; possuírem facilidade de interpretação, detecção e avaliação; serem confiáveis, terem sensibilidade à metodologia empregada. ALMEIDA (2002) enfatiza como características importantes dos indicadores, a capacidade de demonstrarem simplicidade e clareza dos resultados a serem analisados, assim como o baixo custo de aplicação.

Segundo HILTY e MERENLENDER (2000), os programas de monitoramento biológico baseiam-se na medida de riquezas de espécies e na estrutura trófica do ambiente. O grupo de invertebrados, particularmente os insetos, está entre os mais abundantes e bem sucedidos animais terrestres, tornando-os excelentes bioindicadores ecológicos. Algumas destas espécies são sensíveis às alterações do meio em que vivem. Sendo assim, a rápida destruição de grandes porções de áreas de florestas chega a afetar a estrutura das comunidades mais sensíveis, tanto em nível da diversidade como de sua composição, permitindo a avaliação de ecossistemas reconstituídos, através de estudos comportamentais destes invertebrados.

O monitoramento biológico é uma técnica capaz de avaliar os efeitos de agentes estressores, fornecendo informações de sobrecarga. A sua aplicação sistemática no controle da poluição contribui para verificação da necessidade do estabelecimento de estratégias de controle e medidas de proteção ambiental, além de permitir a avaliação da eficácia de procedimentos técnicos já adotados (LIMA, 2000c).

Ao elaborar programas de monitoramento ambiental, a padronização dos monitores é um fator importante que deve ser bem determinado, já que as reações de um organismo bioindicador não dependem somente do fator a ser monitorado, mas também do nível nutricional, disponibilidade de água, luminosidade, temperatura, idade e fase de desenvolvimento do organismo, características genéticas etc (LIMA, 2000b).

O biomonitoramento ambiental, quando realizado com rigor e pormenorização científica, permite estabelecer um diagnóstico sensível que evidencia as condições da área de estudo. É uma técnica de fácil realização, de baixo custo, cujos resultados podem ser obtidos em um curto período de tempo, permitindo a compilação de inventários ambientais compreensíveis que ao serem aplicados por um longo período 
de tempo, acabam por fornecer informações sobre a extensão da influência antrópica. Estas informações auxiliam nas tomadas de decisões, cujos dados podem ser utilizados como um demonstrativo dos benefícios da atuação ambiental responsável, adotada pelo empreendimento (PRADO FILHO; SOUZA, 2002).

\subsection{BIOINDICADORES}

Recentemente, vem sendo desenvolvida pesquisa voltada para a utilização de bioindicadores na avaliação dos impactos na estrutura e função de ecossistemas, ocasionados por ações antrópicas. O uso de organismos vivos como indicador de qualidade ambiental é considerado por OLIVEIRA; MATOS e GONÇALVES (2001), como uma excelente estratégia para o monitoramento ambiental e, segundo WINK et al. (2005), trata-se de uma importante ferramenta que pode ser utilizada no monitoramento de áreas degradadas.

ALLABY (1992) define os bioindicadores como organismos vivos que possuem relações estreitas de amplitude com respeito a uma ou mais características ambientais, sendo que sua presença no ambiente indica uma posição particular ou um conjunto de condições ambientais.

A bioindicação é definida, por LIMA (2000c), por reações de organismos vivos frente a estímulos ambientais provenientes de um determinado poluente, capazes de provocar várias alterações no seu funcionamento, como exemplos podem ser citados as alterações na composição química, na concentração de substâncias de aspectos anatômicos, fisiológicos, de desenvolvimento, ecológicos etc.

A influência antrópica é capaz de gerar novas condições ou modificações nas condições ambientais já existentes e para que a bioindicação seja utilizada na definição de reações ambientais, causadas por modificações antrópicas, ao longo do tempo, é importante o reconhecimento das "respostas" de um sistema biológico frente a uma determinada condição ambiental. As respostas emitidas pelos sistemas biológicos são dadas diante da totalidade do ambiente que o circunda, assim, além da influência 
antrópica, devem ser consideradas as reações dos sistemas biológicos já existentes, que são dadas pela influência do estado nutricional interno (nível nutricional, idade, grau de tolerância etc) e pelas condições ambientais naturais (LIMA, 2000c).

Consideram-se bioindicadores as plantas ou animais (indivíduos ou comunidades) que respondem à poluição ambiental alterando suas funções vitais ou acumulando toxinas (LIMA, 2000a). Podem ser usados para indicar mudanças que afetam a saúde de um ecossistema, visando à conservação dos habitats e ao manejo correto dos recursos naturais, porque a simples presença ou ausência de uma população pode servir como parâmetro a ser avaliado (OLIVEIRA; MATOS; GONÇALVES, 2001). Logo, é possível avaliar a qualidade do ambiente por meio de alterações de substâncias no organismo, do estudo do próprio organismo frente a uma perturbação, ou por meio do estudo do ambiente, onde determinadas espécies bioindicadoras possam estar presentes (LIMA, 2000c).

MCGEOCH (1998) classifica os bioindicadores em: Indicadores Ambientais que são espécies ou grupos de espécies que respondem de forma previsível às perturbações ambientais; Indicadores Ecológicos que são espécies ou grupo de espécies consideradas sensíveis a alterações como perturbação e fragmentação dos habitats, mudanças climáticas, poluição entre outros fatores que geram degradação da biodiversidade; e Indicadores de Biodiversidade que são espécies, guildas ou grupos selecionados de espécies que refletem índices de diversidades a outras espécies presentes no habitat.

Muitas características permitem classificar um organismo como bioindicador, sendo que o conhecimento detalhado da taxonomia, ciclo de vida, e biologia de uma espécie, é de essencial para permitir esta classificação (LIMA, 2000a). Tendo por base LIMA (2000a), DALE e BEYLER (2001) e ARCILA e LOZANO-ZAMBRANO (2003), para validar um organismo como bioindicador, tais organismos devem apresentar as seguintes funções:

- ter facilidade de amostragem;

- ter facilidade de manipulação e tratamento,

- ser facilmente padronizável, 
- ser sensível e possuir comportamento conhecido frentes às mudanças ambientais,

- ser reconhecida suas condições de respostas,

- possuir respostas facilmente avaliadas estatísticamente,

- ser abundante,

- ter capacidade de identificar a diversidade de espécies em uma determinada área,

- ser capaz de informar sobre a estrutura, funcionamento e composição dos sistemas ecológicos,

- ser capaz de detectar alterações no estado do ambiente,

- ser capaz de monitorar as mudanças detectadas, por longos períodos,

- ser capaz de demonstrar o impacto causado por um fator de estresse sobre uma biota,

Segundo LIMA (2000a), há diferentes formas de bioindicação, uma vez que os organismos bioindicadores são capazes de emitirem diferentes respostas frente a uma perturbação ambiental, entre elas:

- a reação do bioindicador, diante do número de modificações ambientais ocorridas, permite sua classificação em específica e não específica, sendo que, a bioindicação específica ocorre quando somente uma ação antrópica provoca a reação, e a bioindicação não específica ocorre quando a mesma reação pode ser provocada por diferentes ações antrópicas.

- a bioindicação também pode ser classificada como direta ou indireta, já que na natureza, por regra, a bioindicação se registra em cadeias de reações ou processos, sabendo que a bioindicação direta ocorre quando a ação antrópica atua diretamente sobre o sistema biológico e a bioindicação indireta ocorre quando ela se manifesta como resultado de alterações de condições ambientais que provocam diferentes respostas.

- o bioindicador pode ser classificado como sensível ou acumulativo. O bioindicador sensível reage com modificações significantes em seu comportando, e um bioindicador acumulativo reage acumulando as influências antrópicas que não podem ser reconhecidos em um curto espaço de tempo, mas em casos de acúmulos 
significativos são capazes de provocar alterações de processos fisiológicos e biocenóticos, ou seja, na evolução e inter-relacionamento das comunidades. Considerando que um organismo, frente às conseqüências de uma ação antrópica, pode apresentar uma cadeia de reações, a primeira reação é denominada bioindicação primária e as demais de bioindicação secundária.

- bioindicadores também podem ser classificados quanto à escala cronológica das reações ocorridas, porque, o bioindicador pode não sofrer reação após um determinado período ou reagir com uma única e forte resposta. No caso da ocorrência de reação, a resposta pode ser: repentina e intensa, permanecendo por alguns minutos e desaparecendo rapidamente; ter intensidade contínua, desde o início da perturbação e permanecer durante muito tempo; ser imediata com perda gradativa de intensidade ao longo do tempo; ser imediata desde o início da perturbação e após atingir seu máximo ter sua intensidade reduzida progressivamente; ocorrer em ciclo com a repetição de reações imediatas com perdas gradativas de intensidade.

Segundo MCGEOCH (1998), o termo bioindicador vem sendo aplicado em vários contextos, por exemplo, na indicação de alterações de habitats, sucesso da evolução de áreas reflorestadas, alterações climáticas, degradação dos solos e ecossistemas, estudos de recuperação ambiental, estudos de contaminação etc.

É importante o reconhecimento do efeito biológico provocado por uma ação antrópica, em tempo hábil, possibilitando a tomada de providências de controle. $O$ uso de bioindicadores muito sensíveis em programas de monitoramento ambiental possibilita uma rápida resposta com o mínimo de interferência (LIMA, 2000a).

A maioria dos trabalhos com bioindicadores, em ecossistemas terrestres, contempla o estudo de espécies vegetais. O acompanhamento da evolução de sucessão e a avaliação da qualidade do ambiente se dão por meio de espécies mais sensíveis às perturbações ocorridas em um determinado local, isto é, as modificações ambientais causadas por algum tipo de poluição, as quais provocam reações no organismo bioindicador, causando alterações em seu comportamento ou funcionamento. Este tipo de estudo é útil na avaliação da qualidade do local, onde tais espécies ocorrem (LIMA, 2000a; LIMA, 2000b). 
Espécies da fauna são mais utilizadas como bioindicadores da qualidade de ecossistemas aquáticos, apesar de poucos trabalhos publicados, algumas espécies da fauna também podem ser utilizadas como bons bioindicadores de ecossistemas terrestres, por certo, os invertebrados.

À medida que cresce o número de trabalhos publicados sobre as comunidades de invertebrados, estas vêm ganhando maior importância, assim passam a ser utilizadas em estudos de conservação e manejo de ecossistemas (BROWN, 1997); o que acaba trazendo um maior entendimento da função destes organismos na manutenção e produtividade dos ecossistemas (MCGEOCH, 1998).

Alguns autores citados por WINK et al. (2005), desenvolveram estudos capazes de classificar espécies da fauna como bons bioindicadores, entre eles a fauna do solo e da serapilheira. A alta diversidade e a capacidade de rápida reprodução tornam essas espécies excelentes bioindicadores capazes de determinar a qualidade ou o nível de degradação do solo e avaliar a estrutura e a funcionalidade dos ecossistemas. Do mesmo modo, o estudo de comunidades de insetos, em se tratando de espécies altamente influenciadas pela heterogeneidade do habitat, é capaz de avaliar o impacto na formação de fragmentos de vegetação. Além disso, os insetos são considerados como organismos benéficos na sustentabilidade ecológica.

Coletas de bioindicadores, quando realizadas sistematicamente e por um longo período de tempo, permitem a identificação de mudanças no ecossistema, possibilitando a compilação de inventários ambientais compreensíveis, que podem fornecer informações sobre a extensão da influência antrópica. Existem vários níveis de estudos dos efeitos, que vão desde a resposta de um indivíduo até o da comunidade como um todo. A abordagem vai depender da questão a ser respondida e, de acordo com essa questão, o período de observação pode variar de poucos dias a vários anos (LIMA, 2000c). 


\subsection{AS FORMIGAS COMO INDICADORAS DA QUALIDADE AMBIENTAL}

Dentre os grupos de invertebrados que apresentam requisitos de indicadores ecológicos do ambiente terrestre, podem ser citados: formigas, aranhas, cupins, abelhas, vespas e besouros. Dentre esses, a formiga é bastante utilizada como bioindicador da avaliação da qualidade e integridade de um habitat. Todas as formigas pertencem a uma mesma família Formicidae. Dentro das Formicidae, existem 17 subfamílias atualmente identificadas, das quais somente oito ocorrem no Brasil, a saber: Cerapachyinae, Dolichoderinae, Ecitoninae, Formicinae, Leptanilloidinae, Myrmicinae, Ponerinae e Pseudomyrmecinae. Mais de 8.500 espécies já foram descritas em nível mundial e, destas, aproximadamente 2.100 espécies foram registradas somente na região neotropical (HÖLLDOBLER; WILSON, 1990). Segundo CAETANO; JAFFÉ e ZARA (2002) o número estimado de espécies de formigas é de 20.000 .

Segundo FOWLER; SCHILINDWEIN e MEDEIROS (1994), as formigas são candidatas ideais a bioindicadores por serem relativamente bem conhecidas e fazerem parte de um dos grupos de insetos sociais de ampla distribuição geográfica, com exceção dos pólos e acima de 3000 metros de altitude (CAETANO; JAFFÉ; ZARA, 2002), ocorrem em quase todas as regiões: desertos, florestas inundadas, montanhas, vales, e até mesmo dentro de nossas casas (HERRICK, 1926; apud CAMPOSFARINHA et al., 1997).

As formigas são utilizadas como bioindicadores, principalmente pela grande abundância e ubiqüidade no habitat intacto e em áreas perturbadas (MAJER, 1983), por sua diversidade (BRANDÃO, 1999), plasticidade comportamental e sua importância ecológica e funcional em quase todos os níveis tróficos de um ecossistema (como predadoras e rapina, como detritívoras, mutualista e herbívoras), pela facilidade com que elas são capturadas e sua sensibilidade a alterações do ambiente (MAJER, 1983; GREENSLADE; GREENSLADE, 1984; WILSON, 1987, 1992; ALONSO, 2000). 
A maioria das espécies de formigas constitui colônias fixas e perenes e, por serem relativamente sedentárias, são responsáveis pelas mudanças que ocorrem em escalas relativamente pequenas no espaço e no tempo (ANDERSEN, 1997).

As formigas são importantes na modificação (BESTELMEYER; WIENS, 1996) e formação do solo orgânico (FOWLER, 1998; HÖLLDOBLER; WILSON, 1990; FOGARAIT, 1998), pois transportam alimentos para o interior de seus ninhos, operando na redistribuição das partículas, nutrientes e matéria orgânica, além de melhorarem a infiltração da água, pelo aumento da porosidade e aeração (KASPARI, 2003). Assim, as formigas são capazes de manter e reestruturar a qualidade do solo local, proporcionando a decomposição da matéria orgânica e a reciclagem dos nutrientes (FOWLER et al., 1991), e contribuindo com um importante papel no fluxo de energia, biomassa e na evolução da estrutura das comunidades como um todo (HÖLLDOBLER; WILSON, 1990).

As comunidades de formigas ainda apresentam mudanças relacionadas com os padrões de sucessão vegetal, ou seja, sua riqueza de espécie possui forte correlação com o tipo e a variedade da vegetação, possibilitando também a correlação entre a diversidade deste grupo e a de outros componentes bióticos que ocorrem em uma mesma área de estudo (MAJER, 1983; ANDERSEN, 1995). Assim, sua diversidade tende a aumentar com o aumento da complexidade vegetal, da disponibilidade de microhabitats, e conseqüentemente com uma maior diversidade de alimentos e abrigos. (SOUZA et al., 1998; apud WINK et al. 2005).

ANDERSEN (2000) considera a temperatura, a disponibilidade de abrigos e fontes de alimentos e a estrutura do microhabitat como os principais agentes modificadores das comunidades de formigas, por constituirem variáveis ambientais capazes de controlar sua produtividade e estrutura.

Relação inversa é observada com respeito à dominância das espécies. Em uma área em recuperação, no início da sucessão vegetal observa-se uma alta dominância de uma ou poucas espécies de formigas, à medida que a sucessão da vegetação avança e o habitat se diversifica, a espécie dominante tem sua população sensivelmente reduzida (FOWLER et al., 1991), permitindo a ocupação do habitat por outras espécies de formigas. Dessa forma, em fase intermediária de sucessão, a 
diversidade de espécies de formigas aumenta e a dominância diminui, estruturando o ambiente em verdadeiros mosaicos (aumento da disponibilidade de recursos) (BESTELMEYER; WIENS, 1996); sendo que mosaico de formigas é o resultado de colonização e expansão, e ou redução espacial entre espécies dominantes e é estruturado pela competição entre as espécies por espaço, abrigos e recursos alimentares (FOWLER et al., op.Cit.).

Em estágios avançados de sucessão, ou seja, em áreas já recuperadas, existe uma tendência à estabilização do habitat ocasionada pela redução dos distúrbios ambientais, assim, algumas espécies de formigas tendem a maior dominância. As espécies dominantes em estágios iniciais de sucessão vegetal são diferentes das espécies dominantes em estágios avançados de sucessão.

Este padrão está relacionado à noção de que picos de diversidade são comuns nos níveis intermediários do processo de sucessão e enfatiza que em locais com altos distúrbios ou baixa produtividade, poucas espécies tolerantes ao estresse ou generalistas conseguem sobreviver; em locais com baixos distúrbios ou alta produtividade, algumas espécies podem conseguir domínio competitivo e acabam por excluir outras espécies, reduzindo a diversidade da comunidade. Assim, uma estrutura vegetal reduzida pode levar a uma diversidade mais baixa e uma dominância alta nas comunidades de formigas (BESTELMEYER; WIENS, 1996).

Outra característica importante que permite a avaliação de alterações ambientais através da indicação do estado de conservação ou de degradação de uma área se dá pelo fato das espécies de uma comunidade local de formigas poderem ocupar diferentes níveis estruturais do habitat, estando presentes em todos os estratos da vegetação (SILVA; SILVESTRE, 2000).

O sucesso das formigas em regiões neotropicais também pode ser atribuído à ampla variedade de estilos de vida que elas apresentam (WILSON, 1987), uma vez que podem ocupar diferentes nichos de forrageamento, que variam de herbívoros a carnívoros, podendo desempenhar papéis importantes nos processos de um ecossistema (BESTELMEYER; WIENS, 1996). Por possuírem uma grande variedade de recursos alimentares, acabam ocupando quase todos os ecossistemas terrestres, 
além de contribuírem, de forma intensa, como dispersoras e predadoras de bancos de sementes (UNDERWOOD; FISHER, 2006).

As formigas vêm sendo utilizadas em diversas áreas, como em minerações, na avaliação de contaminação por pesticidas e em distúrbios de habitats, podendo ainda ser utilizadas para avaliar o impacto do desmatamento (MAJER, 1983). Suas características tornam as comunidades de formigas fundamentais em estudos de impacto ambiental e estudo de áreas degradadas em diferentes estágios de regeneração, ou em áreas florestais com diferentes usos do solo (WINK et al., 2005).

O grau de degradação ou recuperação de uma área, segundo KREMEN et al. (1993), pode ser definido através de estudos simples da fauna de formigas: com a detecção da presença ou ausência de espécies raras e indicadoras em um estado de sucessão definido, através de estudos de similaridade ou dissimilaridade de populações em diferentes áreas, considerando que estas variam conforme o estado de sucessão da vegetação; e através da definição de grupos funcionais. Esta técnica consiste em definir grupos de formigas com características semelhantes, a partir de análises referentes à dieta, ao tipo de aninhamento, método de forrageio etc.

Seguindo a classificação de MCGEOCH (1998), as formigas podem ser classificadas como: indicadores ambientais, indicadores ecológicos e indicadores de biodiversidade, sendo mais estudadas como indicadores ecológicos e de biodiversidade (MAJER, 1983). Para eleger uma espécie ou conjunto de espécies como indicador ambiental, faz-se necessário um bom conhecimento biológico e ecológico da espécie. Segundo DELABIE; AGOSTI e NASCIMENTO (2000), para a maioria das espécies de formigas da região neotropical, esses dados são bastante escassos e desconhecidos, já que a presença de uma espécie determinada pode indicar uma boa integridade ecológica do ambiente, mas sua ausência não significa necessariamente o contrário.

UNDERWOOD e FISHER (2006) fazem uma importante consideração em relação à escala espacial e temporal que influencia as respostas de formigas, particularmente para os distúrbios. Teoricamente, o ideal seria que as respostas medidas fossem apresentadas em escalas espaciais múltiplas, o que permitiria um melhor entendimento das comunidades; posto que as populações de comunidades de formigas variem naturalmente em pequenas distâncias, ou seja, suas características de 
organização social e tamanho de colônias acabam sendo bem diferentes entre as espécies (ARCILA; LOZANO-ZAMBRANO, 2003), as respostas registradas a uma escala podem necessariamente não traduzir para uma outra, sendo que essa variação espacial pode camuflar a detecção das respostas relacionadas a um distúrbio.

Logo, um estudo de monitoramento precisa incorporar réplicas suficientes de lugares perturbados e de referência, além de adquirir dados do pré-distúrbio, tentando estabelecer um conhecimento adequado sobre a dinâmica e composição das comunidades de formigas (UNDERWOOD; FISHER, op. Cit).

Uma consideração espacial crítica que deve ser considerada em estudos de distúrbios ecológicos diz respeito à posição da área de estudo na paisagem, em relação às áreas circunvizinhas, ou seja, o processo de recuperação de uma área é favorecido quando esta área está próxima a ambientes preservados e com diversidade mais elevada de formigas (UNDERWOOD; FISHER, 2006).

Uma consideração importante que se relaciona à escala temporal é o tempo decorrido após o distúrbio no momento que a amostragem de formigas foi conduzida. Uma riqueza e diversidade mais elevada de espécies de formigas são associadas com níveis intermediários de distúrbio, ou estágios de sucessão intermediária de áreas recuperadas, onde a heterogeneidade do ambiente é maior, fazendo-se necessário um monitoramento relativamente longo para definir as variações existentes (HÖLLDOBLER; WILSON, 1990).

Este fato acaba aconselhando a utilização de técnicas que envolvem grupos de espécies como mais adequados, se comparado àquelas que utilizam apenas uma espécie. Os grupos de espécies são caracterizados pela sua função (grupos funcionais) dentro de uma determinada área, ou seja, pelo seu comportamento ecológico, por serem capazes de variar de maneira previsível, em relação ao clima, tipo de solo, vegetação e perturbação (ANDERSEN, 1997).

Os trabalhos que caracterizam os grupos funcionais normalmente se mostram específicos para as condições de cada estudo; este fato, segundo ARCILA e LOZANOZAMBRANO (2003), acaba desvirtuando o propósito inicial do uso de indicadores, sendo necessária à realização de análises que busquem padrões de respostas de grupos funcionais e permitam generalizações e comparações. 
As formigas já serviram como objeto de estudos em várias partes do mundo, como bioindicadoras de perturbação, estabilidade e mudanças do ambiente. $\mathrm{Na}$ Austrália, por exemplo, elas são consideradas particularmente úteis como bioindicadores em programas de análise do meio ambiente devido à sua grande abundância e importância funcional, sua grande variedade de interações com os demais componentes do ecossistema e sua habilidade de integrar um leque de variáveis ecológicas (MAJER, 1982; GREENSLADE; GREENSLADE, 1984).

No Brasil, dentre os diversos estudos com comunidades de formigas, pode-se destacar a utilidade destes invertebrados na avaliação de áreas em recuperação de minerações (MAJER, 1983), avaliação de diferentes práticas de uso do solo (VASCONCELOS, 1999; MAJER; DELABIE, 1999), e efeitos de borda (MAJER, DELABIE; MACKENZIE, 1997). Mas os estudos que prevalecem estão relacionados a levantamentos taxonômicos de formigas, realizados principalmente em regiões de matas (MAJER; DELABIE, 1999). Para ambientes de dunas e restingas existem poucos trabalhos, os quais podem ser citados: BONNET e LOPES (1993), GONÇALVES e NUNES (1984), KEMPF (1978), LUEDERWALDT (1926), revelando a escassez de dados para este tipo de formação.

\subsubsection{Métodos de coleta de formigas}

A abundância e ubiqüidade das formigas nos ecossistemas terrestres, em especial nos trópicos, indicam a facilidade de captura onde são utilizadas técnicas relativamente simples, possibilitando o conhecimento da mimercofauna de uma região, apenas com a utilização de uma técnica (SARMIENTO-M, 2003).

As atividades de monitoramento estão geralmente relacionadas a inventário cujo objetivo é a caracterização da comunidade e o tipo de amostragem exigido é muito diferente de uma amostragem com o propósito de um inventário minucioso e completo (UNDERWOOD; FISHER, 2006). 
O fato das formigas possuírem ampla variedade de estilo de vida e nidificarem e forragearem no solo, na serapilheira, em troncos de árvores em processo de decomposição, na vegetação etc, torna a escolha do método de coleta um ponto bastante crítico, o qual deve ser determinado de modo apropriado para atender o objetivo do monitoramento em questão, pois os métodos não são capazes de coletar igualmente todas as espécies, tendo sua eficácia variando de acordo com o habitat de estudo (BESTELMEYER et al., 2000).

Dentre os diferentes métodos de amostragem utilizados em levantamentos faunísticos de formigas, destacam-se: as coletas manuais, coletas com iscas, extratores de "Winkler", agitação de folhagens, armadilhas do tipo "Pitfall", entre outras.

A coleta manual é considerada por BESTELMEYER et al. (op. Cit.) e SARMIENTO-M (2003) como o método mais indicado para conseguir um levantamento taxonômico completo da riqueza das formigas, contudo requer disponibilidade de muito tempo, habilidade e dedicação e deve ser realizada com o auxílio de instrumentos que facilitam a captura, como pinças, tufos de algodão e pincéis embebidos em álcool etc. Além do solo e na vegetação, as formigas podem ser coletadas manualmente através de quebra de troncos e gravetos, aberturas de epífitas e sementes.

A técnica de coleta com iscas utiliza um pedaço de alimento posto sobre um papel ou em um recipiente plástico, que pode ser disposto no solo ou na vegetação em alturas estipuladas. Como alimento pode ser utilizado uma proteína, um pedaço de salsicha ou atum; um açúcar, um chumaço de algodão embebido em líquido açucarado ou mel.

A padronização do tamanho das iscas é importante para possibilitar comparações futuras. Este método tende a capturar, com maior freqüência, formigas generalistas ou dominantes e o tipo de isca utilizada acabam influenciando a captura, porque as formigas possuem hábitos alimentares diferenciados. $O$ uso de isca pode negligenciar a captura de elementos dominantes da comunidade, decerto que, as formigas cultivadoras de fungos não são atraídas por iscas (UNDERWOOD; FISHER, 2006).

O extrator de "Winkler" é utilizado para captura de invertebrados existentes no solo, e no caso das formigas, excelente para captura dos grupos mais críticos, ou seja, 
das minúsculas formigas que acabam sendo escassas na captura manual. Esta técnica consiste em coletar amostras de solo e serapilheira, os quais devem ser colocados em uma bolsa plástica completamente vedada, para evitar que os animais fujam. Os animais de interesse são separados através de um crivo, e acabam caindo em recipientes menores, a partir de fortes agitações das bolsas plásticas (BESTELMEYER et al., 2000). Segundo UNDERWOOD e FISHER (2006) essa técnica provou ser mais eficiente em matas de dossel fechado, onde a quantidade de serapilheira é maior e mais úmida.

A técnica de agitação de folhagens é utilizada para coletar formigas que forrageiam os galhos e folhas das plantas que estejam ao alcance do pesquisador. É composto por um coletor e um mastro. O coletor pode ser um pano ou plástico branco resistente com suas extremidades presas a varetas. A vegetação é fortemente balançada e as formigas são capturadas com o auxílio de instrumentos de coleta manual, após caírem no coletor SARMIENTO-M (2003).

Segundo BESTELMEYER et al. (2000), uma armadilha do tipo "Pitfall", consiste em um recipiente de superfície interna lisa, quase perpendicular, que pode variar de formato e tamanho, por exemplo, vasos e copos descartáveis. Estas armadilhas devem ser enterradas rente ao solo, de maneira a capturar as formigas ao seu redor e, para que elas fiquem presas, as armadilhas devem ser preenchidas a um terço de seu volume, com um composto líquido contendo água, detergente e, se necessário, conservante (SARMIENTO-M, 2003).

O diâmetro da abertura da armadilha pode afetar a eficiência das coletas em relação ao tamanho das formigas capturadas, sendo aconselháveis armadilhas menores (40 -70 mm de diâmetro) pela facilidade de manuseio e melhores em estudos de coletas exclusivamente de formigas (BESTELMEYER et al., 2000).

O sucesso desta técnica se dá pela adequada montagem, sendo recomendado:

- durante a abertura da cavidade para enterrar a armadilha, deve-se ter o cuidado para que a perturbação da área circundante seja mínima;

- a cavidade deve ser suficientemente profunda para que a borda da armadilha fique ao nível da superfície do solo e tenha vários pontos de contato que facilitem o acesso das formigas; 
- após a armadilha ser enterrada, deve-se espalhar uniformemente a serapilheira para simular o ambiente original e permitir que as formigas transitem normalmente pelo local;

- é recomendado, quando possível, deixar as armadilhas fechadas no local, por alguns dias, antes de destampá-las e tratá-las com o composto líquido, evitando assim, o efeito da perturbação local;

- deve-se ter o cuidado com a queda de material dentro das armadilhas, no momento de sua colocação ao solo, de modo a deixar o líquido mais limpo, facilitando a separação da amostra, após o período de coleta.

A armadilha "Pitfall" é em uma técnica de baixo custo, que oferece uma estimativa parcial da verdadeira abundância de forrageadoras, sendo utilizada para representar a abundância relativa da composição da fauna de formigas que vivem na superfície do solo (epigpeicas) (BESTELMEYER; WIENS, 1996; FISHER, 2005). Para atrair determinadas espécies de formigas, as armadilhas "Pitfall" podem conter iscas que devem ser fixadas mediante o auxílio de um arame preso na parte interna e acima do nível do líquido, sendo que as mesmas devem ser centralizadas e estarem na altura da borda da armadilha, evitando qualquer contato com as laterais (SARMIENTO-M, 2003).

Entretanto, as armadilhas "Pitfall" acabam coletando uma maior proporção de formigas epigpeicas (de superfície) quando as armadilhas são fixadas próximas aos ninhos, sem contar que algumas espécies são pobremente amostradas devido ao ambiente arbóreo ou ambiente hipogéico (de subsuperfície) (BESTELMEYER; WIENS, 1996).

Já quanto à disposição espacial das armadilhas nas unidades de amostragem, devido ao caráter social das formigas, assim como suas diferentes preferências para se alojarem (aninharem), SARMIENTO-M (op.Cit.) recomenda o uso de transectos lineares simples, como a forma mais eficiente de disponibilizar as armadilhas; para fim de padronização, recomenda a distribuição dos pontos de amostragem a cada 10 metros, ao longo do transecto.

BESTELMEYER et al. (2000) recomendam um período de 2 a 3 dias como suficiente para a captura de formigas que forrageiam em torno da armadilha, 
fornecendo uma medida de abundância. A temperatura e a umidade possuem efeitos marcantes nas atividades das formigas, necessitando um período mais longo de coleta, nas estações mais frias e secas do ano; e períodos de coletas mais curtos em épocas chuvosas.

Em um estudo com finalidades de monitoramento ou de comparação de comunidades de formigas os dados coletados devem ser relacionados às avaliações das diferenças nas comunidades, entre áreas ou habitats (como na avaliação da degradação ou na recuperação ambiental), sendo que diversas características podem ser examinadas como respostas das variações ambientais: riqueza, composição de espécies, abundância de forrageiras, comportamento de forrageio e densidade da colônia (BESTELMEYER et al., 2000).

UNDERWOOD e FISHER (2006) avaliaram a eficiência dos métodos de amostragens em relação à capacidade de coleta das espécies e pelas respostas de variáveis relatadas, ou seja, riqueza, diversidade, abundância, e uso de espécies de grupos funcionais. Tanto as armadilhas "Pitfall", como as amostragens de serapilheira, são capazes de fornecer informações sobre a riqueza, composição, abundância relativa e freqüência das espécies (BESTELMEYER et al., 2000), e ambos os métodos são capazes de capturar números similares de espécies e estimar cerca de $69 \%$ e $61 \%$, respectivamente da riqueza total das espécies locais.

O método que utiliza iscas também é capaz de fornecer informações sobre riqueza, abundância e composição de espécies em uma área, embora seja utilizado para atrair espécies generalistas de acordo com a escolha da isca. KING e PORTER (2005) consideram este método menos produtivo, predizendo cerca de $46 \%$ da riqueza total de espécies locais.

O custo financeiro das coletas, equipamentos e o tempo investido diferem com o método de coleta, como amostras de serapilheira levam mais tempo para serem coletadas, triadas e processadas comparadas com as armadilhas "Pitfall" e iscas; sem contar o processo de pós-coleta, no qual há a necessidade de separar um enorme número de espécies a serem identificadas. O processo de identificação requer um investimento de treinamento taxonômico, tornando esta etapa mais cara que a etapa de coleta. 
Segundo UNDERWOOD e FISHER (2006) existem várias estratégias capazes de reduzir o custo e o esforço envolvido nas identificações, a classificação das formigas em morfoespécies, baseado em sua morfologia externa, ou em classificações em escalas mais comuns, como gêneros que são muito mais fáceis de serem identificados do que a complexa taxonomia ao nível das espécies, tornando o processo mais eficiente em termos de tempo, custo e perícia.

Esta técnica de substituição está baseada na premissa de que espécies numerosas de um só gênero, freqüentemente co-ocorrem. Mesmo assim, para garantir o sucesso do programa de monitoramento é muito provável a necessidade de consultorias de um especialista de formigas, para uma perícia taxonômica em alguns pontos, sendo que o nível desse envolvimento depende dos objetivos do monitoramento.

A existência destes diferentes métodos de coleta acaba dificultando uma comparação direta dos poucos estudos existentes, sendo necessária uma padronização de técnicas e métodos para comparação quantitativa entre comunidades de diferentes localidades (SILVESTRE; BRANDÃO, 2000). Para a escolha de um método mais adequado para uma determinada área de estudo, devem-se observar, principalmente, as características físicas e biológicas presentes no ambiente que se pretende avaliar. Não existe uma metodologia mais adequada para cada objetivo estabelecido, e sim uma maior ou menor praticidade de aplicação metodológica para cada estudo de caso em particular.

Para o presente trabalho foi aplicada a metodologia de utilização de armadilhas do tipo "Pitfall", devido a sua maior praticidade de aplicação e baixo custo, uma vez que se pretendeu elaborar uma metodologia para a avaliação do nível de desenvolvimento no processo de recuperação de áreas degradadas, que pudesse ter continuidade futura, observando-se que tais coletas deverão ser manejadas por técnicos treinados. 


\subsection{CLASSIFICAÇÃO DAS FORMIGAS EM GRUPOS FUNCIONAIS}

Estudos da ecologia global de formigas de florestas tropicais buscam entender a variação da estrutura e da função de comunidades de formigas em relação a outros biomas, entre tipos de florestas tropicais diferentes, entre estratos diferentes dentro de uma floresta tropical e em resposta a perturbações ambientais (ANDERSEN, 2000). Uma maneira de se entender tais respostas é a classificação das formigas em grupos funcionais, que transcendem os limites biogeográficos e respondem diretamente ao estresse e à perturbação (SMITH; SCHGART; WOODWARD, 1997).

Devido a características como alta abundância relativa e capacidade de resposta às modificações na estrutura dos sistemas naturais, as formigas podem ser classificadas em categoria funcionais e essa possibilidade as torna um grupo de organismos importantes na evolução do estado e condições do ambiente (SILVESTRE, BRANDÃO; SILVA, 2003).

Classificar uma comunidade em grupos funcionais consiste em descrever sua composição em guildas, ou seja, o reconhecimento de grupos de organismos que utilizam os mesmos tipos de recursos e estratégias na aquisição de alimentos e na ocupação de seus ninhos. O reconhecimento das guildas pode ser utilizado como uma importante ferramenta nos estudos de comunidades, pois permite realizar comparações funcionais entre composições de diferentes localidades, confrontando os modelos estruturais das associações e revelando diferenças na ecologia das comunidades observadas (SILVESTRE; SILVA, 2001; SILVESTRE, BRANDÃO; SILVA, 2003), o que permite 0 entendimento da função que esses organismos desempenham na manutenção e produtividade dos ecossistemas (MCGEOCH, 1998).

Para afirmar que um grupo de espécies atua de modo similar no ecossistema deve-se considerar a formação de uma guilda como um conjunto de espécies que sobrepõem o maior número de variáveis ecológicas dentro do nicho multidimensional, sendo correlativas em suas funções ecológicas, independente da descontinuidade dos recursos ao longo de um gradiente espacial (SILVESTRE, BRANDÃO; SILVA, op.Cit.). Pode-se considerar como variáveis ecológicas: a taxonomia, referência trófica, local de 
nidificação, estratégia de forrageamento e recrutamento, padrões de comportamento observado em interações interespecíficas, tamanho das operárias, agilidade etc (SILVESTRE; SILVA, op.Cit.).

Guildas e grupos funcionais podem ser considerados sinônimos, sendo que os grupos funcionais podem ser constituídos de representantes de mais de uma guilda, e uma guilda não pode ser constituída por mais de um grupo funcional; além disso, quanto mais variáveis ecológicas são consideradas na definição de uma guilda, mais nos aproximamos da definição de nicho e quanto menos variáveis ecológicas são consideradas nos agrupamentos de espécies, mais nos aproximamos dos grupos funcionais (SILVESTRE, BRANDÃO; SILVA, 2003.).

Espécies de uma comunidade local de formigas ocupam diferentes níveis estruturais do habitat, compondo desta forma grupos com funções distintas, como por exemplo, a fauna que habita a serapilheira e a fauna que habita exclusivamente o dossel da vegetação (SILVESTRE; SILVA, 2001). A classificação de guildas ajuda a reduzir a complexidade das comunidades de formigas e permite a identificação de padrões em sua estrutura, independente de limites biogeográficos (ANDERSEN, 1997). Com o estudo das formigas classificadas em guildas é possível conhecer a dinâmica de um determinado habitat (SILVESTRE, BRANDÃO; SILVA, op.Cit.), podendo assim ser utilizadas para prever as perturbações ambientais através do estudo da composição das comunidades locais (KING; ANDERSEN; CUTTER, 1998).

O uso de guildas na qualificação ambiental permite o monitoramento para avaliação da recolonização de uma área de revegetação com espécies nativas, sendo que a presença ou ausência de determinados grupos pode refletir, ou não, uma maior estabilidade e eqüidade da comunidade vegetal local (SILVESTRE; SILVA, 2001).

Para BESTELMEYER e WIENS (1996), os grupos funcionais oferencem meios de avaliar as respostas das formigas em relação aos gradientes de uso da terra, usando facilmente as vastas características ecológicas observadas, sem exigir conhecimento detalhado da história natural ou designação das espécies.

Em princípio, a classificação das formigas, em grupos funcionais, foi baseada em estudos australianos desenvolvidos por pesquisadores. Essa classificação das comunidades de formigas em grupos funcionais e sua utilização como bioindicadores 
tem sido realizada com sucesso nas zonas áridas da Austrália (ANDERSEN, 1997). Estudos realizados por KING; ANDERSEN e CUTTER (1998) demonstram que esse mesmo esquema também pode ser utilizado em áreas de florestas tropicais, mas acabam sendo limitados às classificações na forma de guildas, uma vez que esse esquema de grupos funcionais está relacionado com a distribuição da vegetação.

Segundo SILVESTRE e SILVA (2001), a simples aplicação do modelo australiano não é capaz de refletir a diversidade de situações encontradas nas regiões neotropicais, porque nas florestas neotropicais a disponibilidade de nichos e a dinâmica interespecífica está sujeita a um número muito maior de variáveis em relação aos ambientes australianos que são mais abertos; assim, desenvolveram um método aplicativo que se diferencia do utilizado por ANDERSEN (1997) por não se apoiar à estrutura vegetacional e à dominância de determinados táxons, abordando exclusivamente os aspectos ecológicos das espécies de formigas, objetivando a utilização do táxon como bioindicador.

\subsubsection{Os Grupos Funcionais}

\subsubsection{O caso australiano}

Segundo ANDERSEN (2000) é possível aplicar a classificação de formigas em grupos funcionais em estudos de ecossistemas do mundo todo. A ecologia global não se direciona aos detalhes na composição e dinâmica das comunidades de formigas, mas sim procura compreender como a estrutura e a função de comunidades de formigas varia entre biomas, entre diferentes estratos de uma mesma floresta, e em resposta as perturbações ambientais. Os padrões dos grupos funcionais podem ser reconhecidos em relação ao clima e a vegetação, variando entre as zonas climáticas e com o tipo e complexidade da vegetação.

A distribuição das formigas em grupos funcionais foi desenvolvida por ANDERSEN (1997) e teve início nos estudos de GREENSLADE (1978) e ANDERSEN 
(1987), com observações de campo, do comportamento de algumas espécies de formigas em áreas australianas. Baseando no esquema Australiano, desenvolvido por ANDERSEN (1997), BROWN JR (2000) os gêneros de formigas de todo o mundo foram classificados em 7 (sete) grupos funcionais: Dominantes Dolichoderinae (DD); Subordinada Campotini (SC); Especialistas Climáticas (HCS/CCS/TCS): Especialistas de Clima Quente (HCS), Especialistas de Clima Frio (CCS) e Especialistas de Clima Tropical (TCS), Espécies Cripticas (C), Oportunistas (O), Generalistas Myrmicinaes (GM), e Predadoras Especialistas (SP).

Nos estudos desenvolvidos na Austrália, com clima temperado e semi-árido, a composição dos grupos funcionais responde previsivelmente à perturbação do ambiente, registrando vários padrões de comportamento. Como a estrutura da vegetação é pouco complexa, os ambientes tendem a ser mais abertos e a insolação na superfície do solo maior, favorecendo os grupos Dominantes Dolichoderinae (DD), Especialistas de Clima Quente (HCS) e Generalistas Myrmicinaes (GM); com o aumento da complexidade da vegetação, os ambientes tendem a ser mais fechados proporcionando maior quantidade de sombra, o que reduz a insolação na superfície do solo, reduzindo a abundância de Dominantes Dolichoderinae (DD) e Especialistas de Clima Quente (HCS) e favorecendo o aumento das Generalistas Myrmicinaes (GM) e das Oportunistas $(\mathrm{O})$. A redução da insolação favorece a abundância relativa das Especialistas de Clima Frio (CCS) e das Espécies Cripticas (C) (ANDERSEN, 2000).

Assim, as Dominantes Dolichoderinae (DD) e as Oportunistas (O) têm sua população favorecida de nível baixo a moderado de perturbação devido à suas preferências para ambientes mais abertos, enquanto grupos mais especializados como as espécies Cripticas (C) e as Predadoras Especialistas (SP) estão geralmente ausentes em áreas perturbadas. As Generalistas Myrmicinaes (GM) ocorrem em muitos ambientes com exigências relativamente não especializadas e as Especialistas de Clima Quente (HCS) são adaptadas às condições áridas (UNDERWOOD; FISHER, 2006).

As formigas forrageadoras de chão (epigpeicas) possuem composição de grupos funcionais distintos de acordo com os diferentes tipos de florestas tropicais. Os trópicos de baixa altitude caracterizam-se pela presença dos grupos Generalistas Myrmicinaes 
(GM), Espécies Cripticas (C), Especialistas de Clima Tropical (TCS) e Predadoras Especialistas (SP). Com o aumento da latitude e/ou altitude a diversidade e abundância das espécies Cripticas (C), Generalistas Myrmicinaes (GM) e Predadoras Especialistas (SP) diminuem e as Especialistas de Clima Tropical (TCS) são substituídas pelas Especialistas de Clima Frio (CCS) (ANDERSEN, 2000).

O estudo da ecologia global baseada em grupos funcionais, em relação ao estresse e perturbação, deve ter seu poder de precisão somente voltado para análises de ampla escala, sendo inadequada para uma compreensão detalhada das dinâmicas de comunidade particulares. É capaz de proporcionar uma estrutura previsível para análise da composição da comunidade e domínio comportamental em ou entre florestas tropicais, e as respostas de formigas de florestas tropicais, frente aos distúrbios ambientais ANDERSEN (op. Cit.).

ANDERSEN (op. Cit.) prevê uma tendência para um resultado em comum entre as regiões biogeográficas na distribuição do domínio comportamental e entre tipos de florestas tropicais e na mudança da composição dos grupos funcionais em relação ao estresse (variação da temperatura) e perturbação. Contudo, os efeitos da perturbação na composição dos grupos funcionais, na comunidade de formigas de floresta tropical, vêm sendo pouco documentados, existindo a necessidade do desenvolvimento de mais estudos relevantes que pudessem acompanhar a variação na composição destes grupos, diante dos efeitos de outros tipos de distúrbios ambientais (outros além do desmatamento). Permitindo assim a confirmação dos padrões registrados e a avaliação do uso dos grupos funcionais globais como uma ferramenta valiosa na compreensão da dinâmica das comunidades de formigas de florestas tropicais.

\subsubsection{O caso do Chaco argentino}

BESTELMEYER e WIENS (1996) avaliaram as formigas do Chaco argentino e as classificaram utilizando uma árvore de decisões baseadas primeiramente nas diferenças de uso do habitat (arboreal, epigpeicas e hipogéicas), tipo de forrageamento e dietas das espécies epigpeicas (cultivadoras de fungos - Attini, legionárias - Ecitonini, 
necrófagas e predadoras de pequenos invertebrados - Predadoras Especialistas), e finalizando com a subdivisão das necrófagas, de acordo com suas atividades e dominâncias (Dominantes Dolichoderinae, Camponotus, Especialistas Climáticas, Generalistas Myrmicinae e Oportunistas). Os critérios utilizados para definir a composição dos grupos funcionais foram os mesmos desenvolvidos para as comunidades das formigas australianas.

Em quase todos os casos seguiu-se a relação já existente de distribuição, com exceção dos gêneros mais diversos, os quais foram subdivididos, definindo ao todo, 10 (dez) grupos funcionais: Generalistas Myrmicinae (GM); Cripticas (Cr); Oportunistas $(\mathrm{Op})$; Attini (At); Ecitonini (Ec); Predadoras (Pr); Camponotus (Ca); Arbóreas (Ar); Especialistas Climáticas (Cl) e Dominantes Dolichoderinae (DD) (ANEXO E).

Para o caso do Chaco argentino, as Especialistas de Clima Quente foram mais abundantes em lugares altamente degradados do que em todas as outras áreas; as espécies Cripticas foram mais abundantes em habitats de moderado a altamente recuperado, ocorrendo em menor proporção em habitats alto a moderadamente degradados; as Predadoras ocorreram em todas as áreas, mas foram abundantes nos habitats altamente recuperados. As Camponotus, Oportunistas, Myrmicinaes Generalistas, Attinis e Ecitonini não revelaram respostas significantes em relação ao uso da terra. Assim, as áreas altamente perturbadas foram caracterizadas pela presença das Especialistas de Clima Quente e das Oportunistas, e ausência das Predadoras Especialistas. Áreas intermediárias, moderadamente perturbadas e moderadamente recuperadas, possuem presença de camada de serapilheira bem desenvolvida, e favorece as espécies Crípticas e Predadoras Especialistas.

Diferentemente do observado na Austrália, no estudo da área do Chaco argentino, as Myrmicinaes não foram afetadas pelo uso da terra. Na Austrália, áreas perturbadas acabam reduzindo as Myrmicinae Generalistas devido à competição com as Dominantes Dolichoderinae, as quais são ausentes na área de Chaco.

Existem poucas diferenças entre os dois estudos, BESTELMEYER e WIENS (1996) utilizaram basicamente os mesmos grupos funcionais descritos por GREENSLADE (1978) e ANDERSEN (2000) para o estudo do Chaco argentino. Em comum, verificamos os grupos funcionais GENERALISTAS MYRMYCINAE (GM), 
CRÍPTICAS ( $\mathrm{Cr}$ ou $\mathrm{C}$ ), OPORTUNISTAS (Op ou O), PREDADORAS ESPECIALISTAS (Pr ou P), CAMPONOTUS (Ca ou SC) e ESPECIALISTAS CLIMÁTICAS (Cl ou HCS, CCS e TCS). Quanto à diferença na classificação, podem ser citados os grupos funcionais: ATTINI (At): grupo formado por formigas cultivadoras de fungos, ECITONINI (Ec): grupo composto por formigas nômades (de correição), ARBÓREAS (Ar): espécies com forrageio e nidificação exclusivamente em árvores e arbustos.

\subsubsection{Descrição dos Grupos Funcionais}

Neste trabalho foram considerados os grupos funcionais descritos por ANDERSEN (2000) e utilizados por BROWN JR (2000) e por BESTELMEYER e WIENS (1996), em relação aos nomes e características de cada grupo funcional. Podemos observar a seguir a descrição e composição de cada um dos 7 (sete) grupos funcionais, descritos nos estudos australianos e registrados na área desse estudo.

1) GENERALISTA MYRMICINAE (GM)

- As espécies deste Grupo Funcional têm ampla distribuição em locais com temperaturas quentes, são normalmente formigas mais abundantes, sendo competitivamente ativas com as Dominantes Dolichoderinae, mesmo em florestas tropicais. (ANDERSEN, 2000; BROWN JR, 2000).

- São consideradas por ANDERSEN (1995), como formigas competitivamente subdominantes, pois são consideravelmente mais tolerantes ao estresse do que as Dominantes Dolichoderinae (DD), tendem a ter um território mais restrito e taxas de atividades mais moderadas e freqüentemente respondem com uma defesa mais determinada nas fontes de alimento.

- Podem nidificar no solo ou em troncos podres e serem coletoras de sementes ou onívoras, ou ainda cultivadoras de fungos (BROWN JR, 2000). 


\section{2) ESPECIALISTAS DE CLIMA TROPICAL (TCS)}

- Considerados como uma das subdivisões do grupo funcional das Especialistas Climáticas, definido por ANDERSEN (2000);

- Este grupo funcional é característico de habitats onde a abundância de Dominantes Dolichoderinae (DD) é baixa. Fora de seu habitat tolerável, elas são, freqüentemente, formigas não Especialistas, com exceção dos considerados "soldados" e as cultivadoras de fungos (ANDERSEN, 2000).

- Esse grupo é composto por formigas que têm ampla distribuição em regiões tropicais úmidas (ANDERSEN, 2000).

- Estas formigas têm ampla distribuição nos trópicos e em áreas com temperaturas quentes, nidificam no solo, em montes de areia e na serapilheira, e são forrageadoras generalistas ou coletoras de sementes (BROWN JR, 2000).

\section{3) SUBORDINADA CAMPONOTINI (SC)}

- Este grupo tem ampla distribuição em todo o mundo, nidificam e forrageiam no solo, em árvores mortas ou dentro de árvores (BROWN JR, 2000), normalmente possuem hábitos noturnos de forrageamento, (ANDERSEN, 2000).

- Diversas e abundantes nas ricas comunidades de formigas, a maioria é submissa em relação às espécies do grupo Dominante Dolichoderinae (DD), e muitas são ecologicamente isoladas devido ao seu grande tamanho de corpo (ANDERSEN, 2000).

- Estas formigas possuem alta capacidade de invasão e se adaptam facilmente a novos locais (OLIVEIRA; DELLA LÚCIA, 1992; apud ROCHA, 2004).

- Por terem sido muito capturadas em áreas de eucalipto e pouco capturadas em áreas de vegetação nativa, estas formigas foram consideradas por MARINHO (2001; apud ROCHA, 2004) como sendo formigas indicadoras de ambiente antropizado. 


\section{4) PREDADORAS ESPECIALISTAS (SP)}

- Este grupo é constituído por espécies de formigas com dieta especializada em predar outros artrópodes. São forrageadoras solitárias, ou seja, com mínima interação com outras formigas, apresentando baixa densidade de população (ANDERSEN, 2000). Elas nidificam na serapilheira, tem ampla distribuição nos trópicos e algumas ocorrências em locais com temperaturas quentes (BROWN JR, 2000).

- Esse grupo compreende espécies de tamanho médio a grande (ANDERSEN, 2000).

- As formigas deste grupo tendem a ter pouca interação com outras formigas, exceto pela predação direta, devido a sua dieta especializada e a sua densidade de população tipicamente baixa (ANDERSEN, 2000).

\section{5) OPORTUNISTAS (O)}

- As formigas que fazem parte deste grupo não são especializadas, são espécies típica de ambientes ruderais, são pouco competitivas e consideradas como espécies primitivas cuja distribuição parece ser fortemente influenciada pela competição de outras formigas (GRIME, 1979; apud ANDERSEN, 2000). Freqüentemente possuem ampla distribuição geográfica, mas predominam somente onde 0 estresse e perturbação são considerados severamente limitantes de sua produtividade e diversidade e, portanto onde o domínio comportamental é baixo. Sua presença pode sugerir um ambiente perturbado (ANDERSEN, 2000). A proximidade da área de coleta com ambientes antropizados pode justificar a presença deste grupo. Possuem ampla distribuição no habitat, sendo fortemente influenciada pela competição com outras formigas (ROCHA, 2004).

\section{6) DOMINANTE DOLICHODERINAE (DD)}

- As espécies pertencentes a este grupo são competitivamente dominantes e geralmente predominam em ambientes de baixo nível de estresse e perturbação, 
portanto, sua presença pode indicar uma melhora no ambiente das florestas australianas. Estas formigas ocorrem de forma moderada, podendo, muitas vezes ser ausente em ambientes estressados. Além disso, possuem distribuição restrita, ou seja, não são encontradas pelo mundo todo (ANDERSEN, 2000).

- em relação às Generalistas Myrmicinae (GM), possuem territórios mais amplos e se mostram com níveis extremamente altos de atividades, além disto, expulsam ativamente outras formigas das fontes de alimentos, (ANDERSEN, 2000).

- Elas são fortemente associadas a locais abertos tais como os desertos, ecossistemas do mediterrâneo e às copas das florestas tropicais. A maioria das espécies é arbórea, (ANDERSEN, 2000).

\section{7) CRIPTICAS (C)}

- Formigas de tamanho pequeno ou diminuto (ANDERSEN, 2000), onde predominam as subfamílias Myrmicinae e Ponerinae. São encontrados principalmente na serapilheira de florestas tropicais, sendo mais diversas e abundantes em habitats arborizados. Nidificam e forrageiam primeiramente nos solos, na serapilheira e em troncos em decomposição (BROWN JR, 2000).

- Estas espécies freqüentemente apresentam ampla distribuição no habitat, mas predominam somente em locais onde o estresse e a perturbação limitam a produtividade e diversidade de formigas, e, portanto, onde o comportamento dominante é baixo (ANDERSEN, 2000).

- Elas são diversas e abundantes em florestas e fazem partes das formigas que vivem na serapilheira de florestas tropicais (ANDERSEN, 2000).

A classificação utilizada por BESTELMEYER e WIENS (1996) pode ser visualizada no Quadro 3. 


\begin{tabular}{|c|c|c|c|c|}
\hline \multicolumn{2}{|c|}{ Habitat / Dieta } & $\begin{array}{c}\text { Grupos } \\
\text { Funcionais }\end{array}$ & Gêneros & Observações \\
\hline \multicolumn{2}{|r|}{ Arboreal } & ARBÓREAS & Zacryptocerus e Pseudomyrmex & $\begin{array}{l}\text { Gêneros constituídos por espécies de formigas que } \\
\text { raramente interagem com espécies de formigas } \\
\text { epigpeicas. }\end{array}$ \\
\hline \multicolumn{2}{|r|}{ Hipogéicas } & CRÍPTICAS & $\begin{array}{l}\text { Forelius, Solenopsis, Pheidole, } \\
\text { Wasmannia, Brachymyrmex }\end{array}$ & $\begin{array}{l}\text { Forrageiras epigpeicas, sendo as Brachymyrmex, as } \\
\text { dominantes de serapilheira. }\end{array}$ \\
\hline \multirow{8}{*}{ 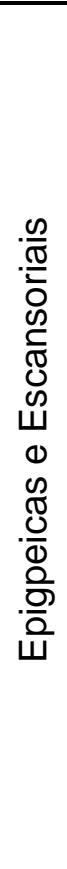 } & $\begin{array}{l}\text { Cultivadoras } \\
\text { de Fungos }\end{array}$ & ATTINI & $\begin{array}{l}\begin{array}{l}\text { Atta, Acromyrmex (cortadoras de } \\
\text { folhas) }\end{array} \\
\text { Trachymyrmex, Mycetophylax e } \\
\text { Cyphomyrmex (coletoras de } \\
\text { detritos) }\end{array}$ & $\begin{array}{l}\text { Espécies cultivadoras de fungos. Em geral, esses } \\
\text { grupos não competem por comidas. }\end{array}$ \\
\hline & \begin{tabular}{|l|} 
Legionárias \\
\end{tabular} & ECITONINI & Eciton e Neyvamyrmex & Formigas nômades soldados. \\
\hline & Predadoras & $\begin{array}{l}\text { PREDADORAS } \\
\text { ESPECIALISTAS }\end{array}$ & Odontomachus e Pachycondyla & Predadoras de pequenos invertebrados. \\
\hline & \multirow{5}{*}{ Necrófagas } & $\begin{array}{c}\text { DOMINANTES } \\
\text { DOLICHODERINAE }\end{array}$ & Iridomyrmex e Oecophyla & Espécies altamente agressivas e dominantes. \\
\hline & & CAMPONOTUS & Camponotus & Abundantes na estação de chuva. \\
\hline & & $\begin{array}{l}\text { ESPECIALISTAS } \\
\text { CLIMÁTICAS }\end{array}$ & Forelius & Especialistas de clima quente. \\
\hline & & $\begin{array}{l}\text { GENERALISTAS } \\
\text { MYRMYCINAE }\end{array}$ & $\begin{array}{l}\text { Crematogaster, } \quad \text { Pheidole e } \\
\text { Solenopsis }\end{array}$ & $\begin{array}{l}\text { Apresentam uma variedade de estilos de vida, tendo } \\
\text { em comum a vasta distribuição no mundo e } \\
\text { exigências de habitats flexíveis. }\end{array}$ \\
\hline & & OPORTUNISTAS & $\begin{array}{l}\text { Dorymyrmex, Ectatomma e } \\
\text { Gnamptogenys }\end{array}$ & Não especializadas e pouco competitivas. \\
\hline
\end{tabular}

Quadro 3 - Classificação dos grupos funcionais do Chaco argentino (ANEXO E). 
CAPÍTULO 3

\section{METODOLOGIA PROPOSTA}

A metodologia proposta, no presente estudo, está baseada em metodologias de estudos de inventários da mirmecofauna, discorridas no capítulo anterior, e em indicações do Prof. Dr. Harold Gordon Fowler, especialista na área de mirmecologia e professor da Universidade do Estado de São Paulo.

O trabalho desenvolvido baseou-se na indicação de uma metodologia capaz de avaliar o nível de recuperação e desenvolvimento da vegetação das áreas após a atividade de lavra e está fundamentada pela necessidade de um monitoramento que acompanhe a evolução deste novo ecossistema e avalie a eficácia das técnicas de revegetação adotadas pelo empreendimento, frente aos objetivos pré-estabelecidos no planejamento e gerenciamento ambiental.

A metodologia proposta deve ter início pela escolha de um bioindicador que possa ser utilizado de maneira eficaz na qualificação de áreas revegetadas. Após definido o bioindicador ideal, deve-se determinar o melhor método de amostragem do bioindicador, a definição da periodicidade das amostragens, escolha das áreas de coletas e processos de pós-coleta (Figura 1), os quais serão descritos a seguir. 

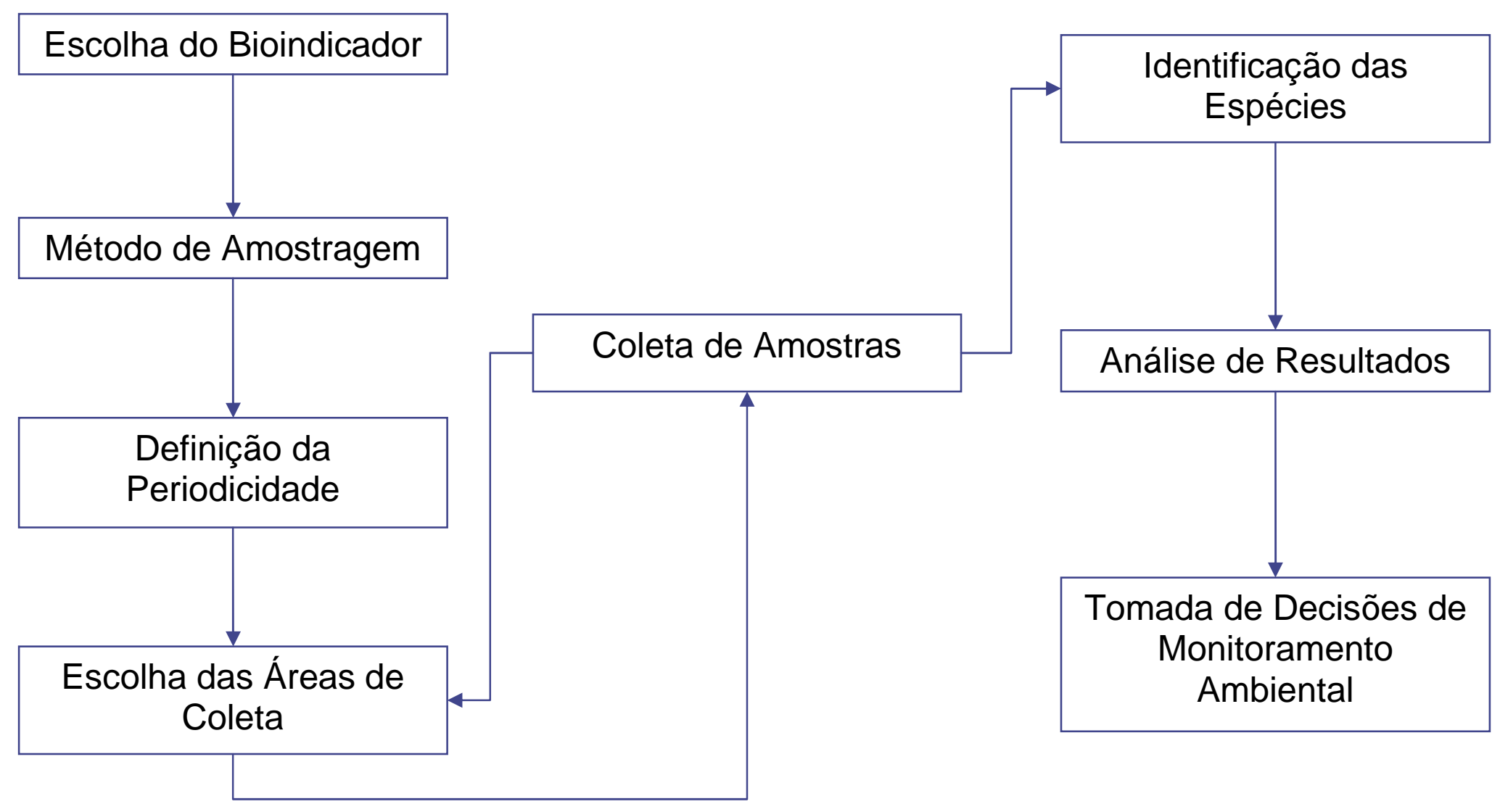

Figura 1 - Fluxo das etapas de biomonitoramento ambiental. 


\subsection{ESCOLHA DO BIOINDICADOR}

Um amplo conhecimento da área de estudo (meio físico e biológico) faz-se necessário para possibilitar a escolha do melhor organismo bioindicador a ser analisado e, a partir disto, escolher o melhor método de amostragem dos bioindicadores, as principais áreas a serem amostradas e a periodicidade das coletas.

Para o presente trabalho optou-se pelo bioindicador pertencente ao filo Arthropoda, classe Insecta, ordem Hymenoptera, família Formicidae, pelo fato de os considerarmos como melhor organismo bioindicador a ser analisado. As formigas são consideradas como excelentes candidatas a bioindicadores na avaliação de recuperação de áreas e esse fato é justificado pelas características já abordadas no item 2.5, do Capítulo 2. Na mineração, os maiores atrativos para a sua adoção como organismo bioindicador incluem: a abundância de espécies e indivíduos; facilidade de captura, sensibilidade às alterações do habitat e o baixo custo de investimento no procedimento de coleta.

\subsection{MÉTODO DE AMOSTRAGEM DE FORMIGAS}

Diante da variedade e complexidade dos métodos existentes para a coleta de formigas optou-se pela utilização de um único método que fosse capaz de coletar quantidade representativa da fauna de formigas existente no local, levando em consideração que a atividade de monitoramento ambiental visa à caracterização da comunidade bioindicadora.

$\mathrm{Na}$ escolha do método de amostragem considerou-se a eficiência na captura de espécies, praticidade de coleta e triagem do material coletado, baixo custo de investimento com material de coleta, aleatoriedade na captura das espécies de formigas, facilidade de manuseio e atendimento ao objetivo do plano de monitoramento.

Assim, a técnica de amostragem de formigas recomendada como ideal é a das armadilhas do tipo "Pitfall". Embora estas armadilhas ofereçam uma estimativa 
parcial da verdadeira abundância de forrageadoras, elas são utilizadas para representar adequadamente a abundância relativa e a composição da fauna de formigas de chão (epigpeicas) (BESTELMEYER; WIENS, 1996).

Esta técnica possui algumas vantagens que se destacam: a possibilidade de promover uma maior capacidade de captura de espécies, permitir o recolhimento de amostras em períodos e locais preestabelecidos e abranger coletas ao longo do dia. Além de não necessitar de mão-de-obra especializada no procedimento de coleta, permite a continuidade do estudo por longos períodos, o que garante a confiabilidade dos resultados do monitoramento ambiental.

De acordo com BESTELMEYER et al. (2000) para facilitar o manuseio do material no campo, recomenda-se utilizar armadilhas menores, tais como frascos de pequena dimensão semelhantes a tubos de ensaio, a fim de possibilitar a caracterização da comunidade de formiga. Ao se estabelecer o monitoramento ambiental não se faz necessário elaborar inventário completo da espécie bioindicadoras presentes na área de estudo.

As armadilhas devem ser enterradas, rente ao solo, com o auxílio de uma ferramenta conhecida como ponteiro, com diâmetro semelhante ao tamanho da armadilha utilizada. Sempre que possível, deve-se adaptar tampas que vedem 0 recipiente (armadilhas), evitando perda de material coletado e facilitando a retirada e o transporte das armadilhas no campo.

Cada armadilha deve ser devidamente etiquetada com dados básicos de localização, como o nome da área, região, número do transecto, número da unidade amostral. Quando possível, recomenda-se anotar o dados de posição geográfica como uma forma precisa de referência. Deve-se ter o cuidado com o tipo de papel, tinta utilizada para anotar as informações e o modo de fixá-las nos frascos, evitando a perda de informações. SARMIENTO-M (2003) recomenda o uso de lápis e papel canson que deve ser depositado dentro dos frascos.

Para facilitar o retorno ao ponto exato de cada armadilha, cada ponto deve ser demarcado e numerado. É importante o uso de sinais ou marcas notórias como fitas sinalizadoras e ou bandeirolas dispostas ao lado de cada armadilha, facilitando o retorno ao local exato e a sua retirada para as devidas análises.

É essencial salientar que os horários de colocação, tratamento e recolhimento das armadilhas devem ser padronizados, minimizando as diferenças climáticas, já que as formigas são organismos climatizados, isto é, apresentam variação horária 
em suas atividades de forrageio. Se as armadilhas foram dispostas no ambiente pelo período da manhã, elas devem receber o tratamento e serem recolhidas também no mesmo período.

A seguir pode-se observar, na Figura 2, um diagrama esquemático, sem escala, da disposição, no campo, das armadilhas "Pitfall's".

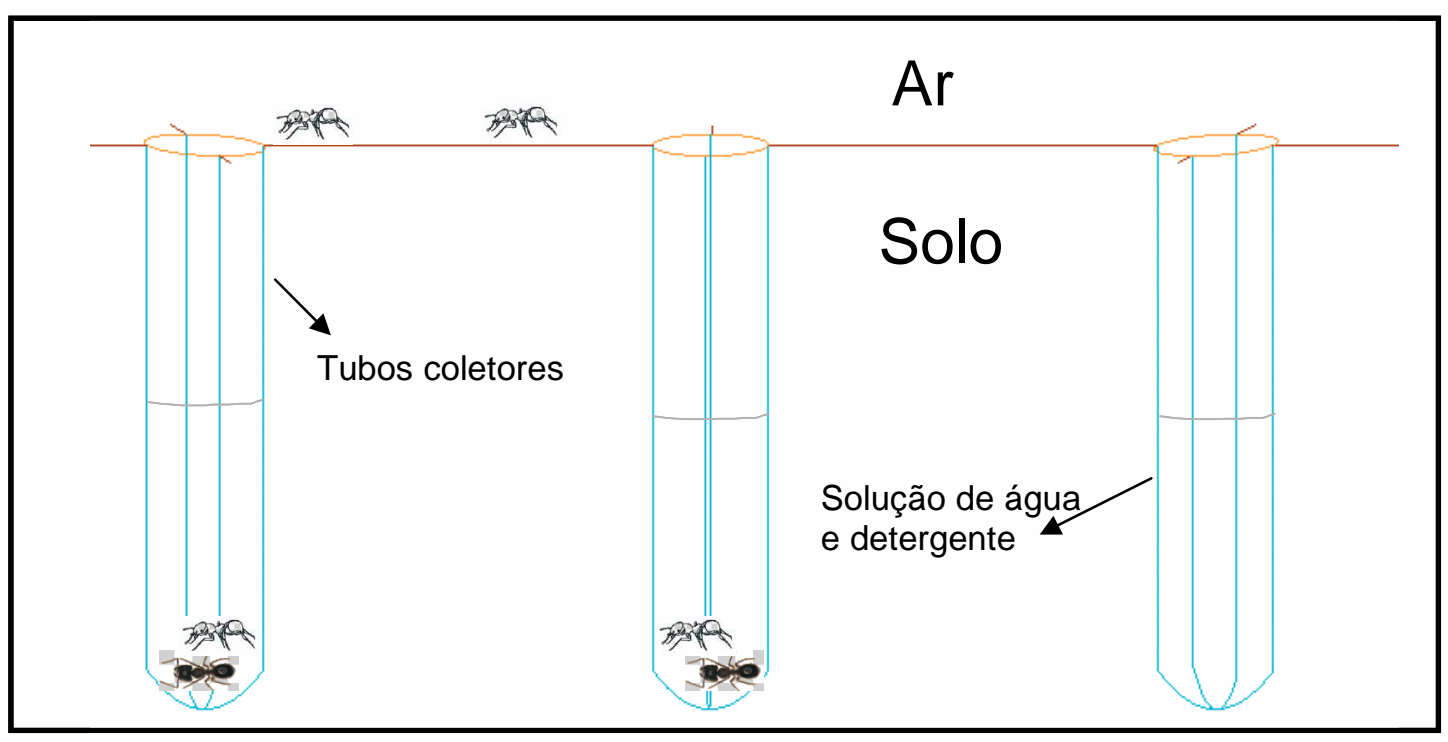

Fonte: informação pessoal ${ }^{2}$

Figura 2 - Diagrama esquemático da disposição das armadilhas "Pitfall's".

Em um primeiro momento, as armadilhas tampadas devem ser colocadas, conforme tratamento descrito acima, para cada área de coleta; após, há necessidade de aguardar no mínimo um dia, pela normalização do ambiente, antes de receberem o tratamento adequado para a coleta, uma vez que o ambiente sofreu um impacto localizado para a montagem de cada armadilha.

Todas as armadilhas devem ser tratadas. $O$ tratamento consiste no preenchimento de cada armadilha com uma solução de água e detergente. A função do detergente é de quebrar a tensão superficial da água fazendo com que os insetos afundem ao entrar na armadilha, impedindo que os mesmos escapem. Tal solução deve ser colocada até, aproximadamente, um terço do volume de cada armadilha, com o auxílio de uma piceta.

As armadilhas abertas e tratadas devem permanecer, no campo, por 48 horas (período mínimo de coleta), conforme recomendado por BESTELMEYER et al.

\footnotetext{
${ }^{2}$ Desenho esquemático elaborado pela autora, 15 de maio de 2002.
} 
(2000). Seguindo o tempo mínimo de coleta, não há a necessidade do uso de conservantes na solução do tratamento das armadilhas, porque o conservante é utilizado para evitar a decomposição do material coletado. E este deve ser utilizado caso a triagem do material não possa ser realizada imediatamente após a retirada das armadilhas do campo.

O tempo de coleta deve ser determinado pelas características sazonais da área de estudo em particular, a saber, que a temperatura e a umidade possuem efeitos marcantes nas atividades das formigas, sendo indicado períodos mais longos de coleta nas estações mais frias e secas do ano e períodos mais curtos de coleta, em épocas chuvosas (BESTELMEYER et al., 2000).

Para uma adequada montagem das armadilhas, é importante seguir algumas recomendações de BESTELMEYER et al. (op.Cit.), já mencionadas, ou seja, evitar grandes perturbações da área circundante de cada armadilha, no momento de sua disposição no campo; proporcionar um adequado contato da borda da armadilha com o solo, para facilitar o acesso das formigas; disfarçar o ambiente ao redor das armadilhas para simular o ambiente original; deixar as armadilhas tampadas por pelo menos um dia antes de destampá-las e tratá-las, evitando o efeito da perturbação local; ter cuidado com a queda de material (terra, folhas e galhos) dentro das armadilhas, facilitando a posterior triagem da amostra coletada.

Seguindo a recomendação de SARMIENTO-M (2003) as armadilhas devem ser dispostas ao longo de transectos lineares com distribuição dos pontos de amostragem a cada 10 metros. O número total de armadilhas deve ser estipulado de acordo com o tamanho das áreas, devendo ser representativo de cada área a ser estudada. Uma vez determinado este número, o mesmo tratamento deve ser aplicado para todas as demais áreas, com a finalidade de padronização do método, permitindo assim a realização de comparação das análises estatísticas representativas de cada área de coleta.

\subsection{DEFINIÇÃO DA PERIODICIDADE}

A definição da periodicidade para as coletas de formigas, ou seja, da quantidade de coleta necessária para cada etapa do estudo de monitoramento 
ambiental deve ser definido de acordo com a variação sazonal local, ou seja, com a variação de dados de pluviosidade, umidade relativa e de temperatura da região a ser monitorada.

O índice pluviométrico da região deve ser analisado, já que as coletas não são recomendadas em épocas de chuva abundante, evitando assim a possibilidade de perda do material coletado.

Para o presente estudo recomenda-se três coletas ao longo de um ano, sendo importante a captura de um número representativo de espécies encontradas no local (informação pessoal) ${ }^{3}$. Este número de coleta foi estipulado pela autora deste estudo com a finalidade de capturar o maior número possível de espécies de formigas.

Este tipo de monitoramento ambiental também pode ser realizado com duas coletas ao longo de um ano, sendo uma coleta na época seca (e/ou fria) do ano e outra na época chuvosa (e/ou quente) (ROCHA, 1999); e até mesmo com apenas uma coleta, que deve ser realizada na época mais quente do ano (maior atividade das formigas) conforme realizado por ROCHA (2004).

Ao definir o número de coletas, todas as demais coletas devem ser padronizadas. As coletas devem ser repetidas, de acordo com a necessidade da empresa, em períodos de aproximadamente cinco a sete anos de forma a permitir o monitoramento destes dados, não sendo indicado intervalos inferiores a cinco anos entre as coletas (informação pessoal) ${ }^{4}$.

\subsection{ESCOLHA DAS ÁREAS DE COLETAS}

A metodologia de biomonitoramento é capaz de avaliar uma ou várias áreas em diferentes etapas de um mesmo processo de revegetação, que tenham, ou não recebido tratamentos diferenciados. Em ambos os casos devem-se contemplar áreas de referência com características semelhantes ao ambiente original, para obter maior precisão da variabilidade que os dados possam apresentar.

${ }^{3}, 4$ Comunicação verbal fornecida pelo Prof. Dr. Harold G. Fowler - Departamento de Ecologia da Universidade Estadual Paulista (Campus de Rio Claro), em 20 de maio de 2002. 
Ao avaliar mais do que uma área revegetada, de um único tratamento, é possível avaliar a evolução temporal das técnicas de revegetação aplicada, com apenas uma coleta, ou seja, logo na primeira etapa do biomonitoramento. Assim, alguns parâmetros, definidos pela autora, devem ser considerados na escolha dessas áreas de coletas:

1) Tempo de revegetação: escolher uma ou mais áreas com idades não muito próximas que possam representar fases distintas do processo de revegetação, ou seja, uma área com processo de revegetação em estágio de crescimento bastante avançado; uma segunda área com estágio de crescimento recente, e uma terceira área, chamada de "área controle", com vegetação nativa, ou seja, ainda não alterada pela atividade da mineração. Outras áreas em fases intermediárias das duas primeiras podem ser contempladas.

2) Tratamento do substrato: escolher áreas com tratamentos de solo homogêneos.

3) Tipo de plantio: dar preferência para a escolha de áreas tratadas com igual técnica de revegetação, como áreas que receberam um elenco misto de espécies nativas.

4) Tamanho anual das áreas revegetadas: devem-se escolher áreas mais homogêneas no tamanho;

5) Disposição e formato: levar em consideração o efeito de borda, e a proximidade das áreas;

6) A escolha da área controle: que possa representar, de forma mais semelhante, o ambiente encontrado anteriormente a atividade de lavra, ou seja, sem ação antrópica recente. Quando possível deve-se selecionar mais do que uma área controle, pois quanto maior o número de áreas controle selecionadas para as coletas de formigas, maior será a variabilidade dos dados de referência, aumentando assim a capacidade de precisão para a comparação dos dados.

A padronização do tratamento do substrato, tipo de plantio e tamanho das áreas é fundamental para que os resultados possam ser comparados. 


\subsection{PROCESSO PÓS-COLETA}

Após cada coleta, inicia-se o processo de triagem de todas as espécies de formigas encontradas em cada área. As espécies de formigas encontradas em cada armadilha devem ser cuidadosamente separadas com o auxílio de pinças, pincéis de cerdas macias e lupa binocular. Todas as amostras devem ser depositadas em frascos individuais contendo conservantes (solução de álcool 70\%), para a conservação de todos os indivíduos encontrados, sendo que cada frasco deve ser devidamente etiquetado com as informações correspondentes de cada armadilha.

Uma atenção especial deve ser destinada à separação dos indivíduos de cada área, permitindo a exata localização das espécies de todos os pontos amostrados. Após a adequada triagem, todo o material devidamente etiquetado deve ser encaminhado a um taxonomista especializado na área de mirmecologia para o processo de fixação dos indivíduos e posterior identificação.

Após a identificação de todas as espécies coletadas, deve ser elaborado um catálogo, em que pelo menos um indivíduo fixado, de cada espécie registrada, será contemplado. A elaboração do catálogo permitirá uma posterior identificação de novas espécies, por comparação. Este procedimento é útil para que somente as novas espécies encontradas sejam encaminhadas para análise pelo especialista, reduzindo ainda mais o custo do método de monitoramento, para a empresa. Os procedimentos necessários para o preparo de cada indivíduo a ser catalogado devem ser realizados conforme indicação do taxonomista especialista em formigas.

Todos os dados coletados e identificados devem ser analisados estatisticamente e, entre os muitos métodos de análises existentes, recomendam-se as análises de riqueza, agrupamento, similaridade e de grupos funcionais. Como estratégia de redução de custo e esforço envolvido no processo de identificação aconselha-se análises ao nível de gênero.

Após a conclusão de todas as etapas, espera-se chegar a resultados satisfatórios, em que serão encontradas uma maior diversidade e espécies especialistas de formigas em áreas mais preservadas e uma menor diversidade e espécies generalistas de formigas em áreas mais degradadas, mesmo assim os dados devem ser analisados estatisticamente e justificados de acordo com as características pertinentes locais. Assim, a presença ou ausência de determinadas 
espécies de formigas auxiliará na avaliação qualitativa da evolução do ambiente de estudo.

Para melhor entendimento dos produtos e resultados de cada etapa descrita, a seguir observa-se o diagrama da metodologia de biomonitoramento ambiental proposta (Figura 3). 


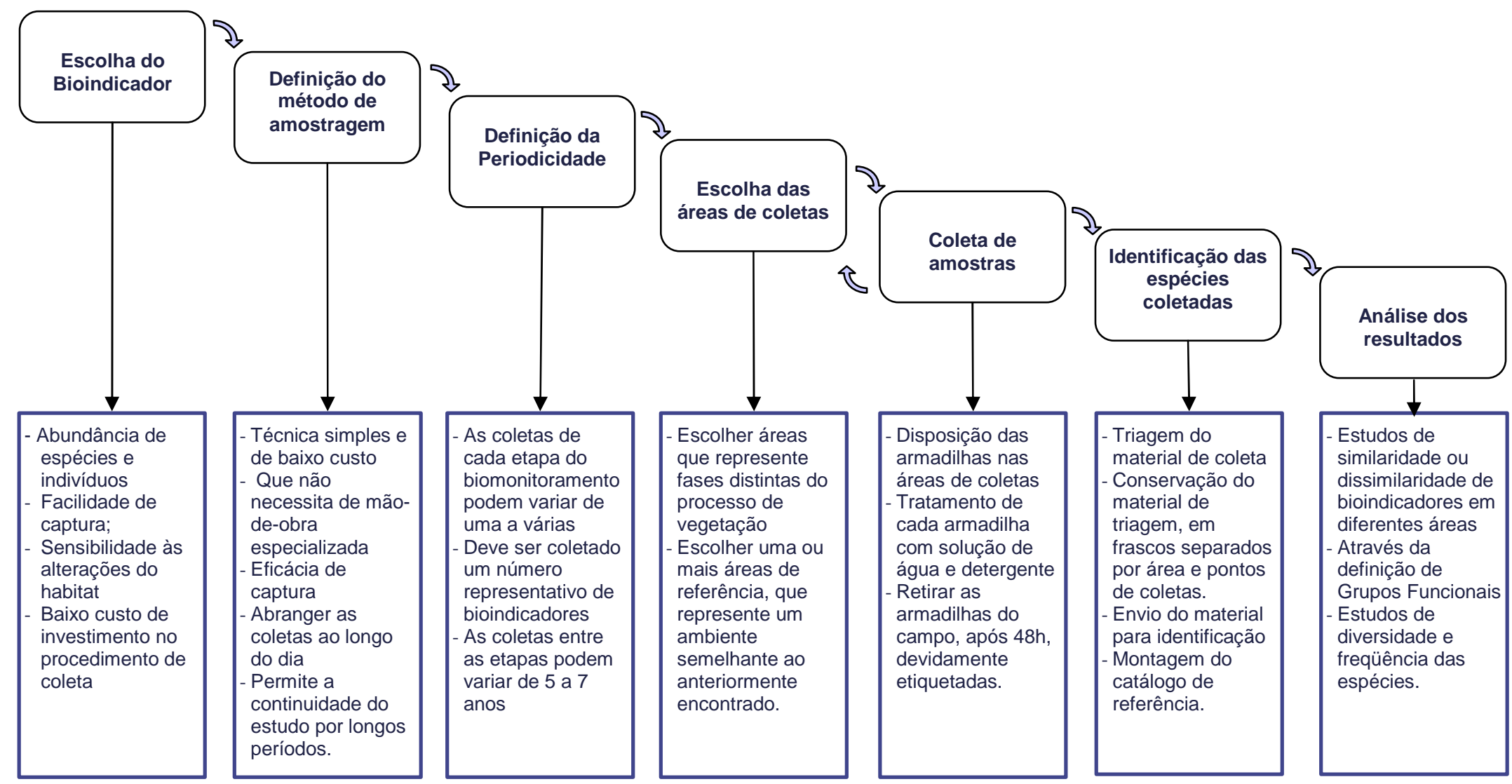

Fonte: informação pessoal ${ }^{5}$

Figura 3 - Diagrama de metodologia de biomonitoramento ambiental: produtos e resultados de cada etapa.

${ }^{5}$ Diagrama elaborado pela autora, 20 de abril de 2007. 
CAPÍTULO 4

\section{ESTUDO DE CASO}

\section{1 ÁREA DE ESTUDO}

O presente trabalho se desenvolve nos domínios da Millennium, empresa do Grupo Lyondell Chemical Company, que extrai e comercializa minerais pesados. A Lyondell Chemicals Comapny possui uma unidade industrial em Camaçari (Bahia), com capacidade de produção de 60 mil toneladas por ano de dióxido de titânio, e uma unidade mineradora em Mataraca (Paraíba), Mina do Guaju, produtora de ilmenita, zirconita, rutilo e cianita. (informação pessoal) ${ }^{6}$

A unidade Mina do Guaju se refere à lavra e beneficiamento dos minerais pesados e vem desenvolvendo com sucesso a recuperação das áreas modificadas pela extração de minérios através de lavra a céu aberto, o que torna possível aplicar a metodologia de monitoramento e permite avaliar a qualidade do ecossistema em formação.

O principal produto fabricado a partir do minério ilmenita, extraído da Mina do Guaju, é o dióxido de titânio, o pigmento mais consumido no mundo ( $70 \%$ do total) e também o mais importante dentre os pigmentos brancos. Este pigmento tem por função conferir brilho, brancura e opacidade a uma grande diversidade de produtos, tais como tintas, plásticos, papel, alimentos, fibras, borrachas e cosméticos (RÉ; MARQUES, 2002).

Dentre os minérios de titânio, a ilmenita é a matéria-prima mais utilizada para a produção de dióxido de titânio, respondendo por mais de $80 \%$ do total mundial. Cinco países - Austrália, África do Sul, EUA, China e Noruega - detêm 69\% das

\footnotetext{
${ }^{6}$ Dados fornecidos pelo Setor de Meio Ambiente da Mina do Guaju - Lyondell Chemicals Company, em 22 de novembro de 2002.
} 
reservas mundiais de ilmenita. No Brasil utiliza-se a ilmenita apenas para a produção de dióxido de titânio (MAIA, 2000).

\subsubsection{Localização e acesso}

A Mina do Guaju está localizada no Distrito de Guaju, do Município de Mataraca, litoral norte do Estado da Paraíba, (Figura 4). A mina situa-se em um campo de dunas fixas e semifixas, na divisa do estado com o Rio Grande do Norte, exatamente entre as coordenadas UTM, visualizada na Tabela 4.1.

Tabela 4.1 - Coordenadas UTM de alguns vértices que delimitam a área da Mina do Guaju.

\begin{tabular}{ccc}
\hline Vértices & $X$ & $Y$ \\
\hline PA & 9282614,292 & 281538,799 \\
1 & 9282332,732 & 282498,749 \\
2 & 9275832,732 & 282498,749 \\
3 & 9275832,732 & 281098,749 \\
4 & 9277832,732 & 281098,749 \\
5 & 9277832,732 & 280698,749 \\
6 & 9280690,258 & 280698,749 \\
7 & 9280690,258 & 280422,186 \\
8 & 9281684,288 & 280422,186
\end{tabular}

Legenda: PA = Ponto de amarração. Fonte: informação pessoal ${ }^{7}$.

O acesso é feito, partindo-se de João Pessoa, pela BR-101, no sentido à cidade de Natal, em que são percorridos cerca de $94 \mathrm{Km}$ até a bifurcação com a PB065. A partir deste ponto, seguem-se mais $25 \mathrm{Km}$, até alcançar a Mina do Guaju (Figura 4).

\footnotetext{
${ }^{7}$ Coordenadas fornecidas pelo Setor de Meio Ambiente da Mina do Guaju - Lyondell Chemicals Company, em 22 de novembro de 2002.
} 


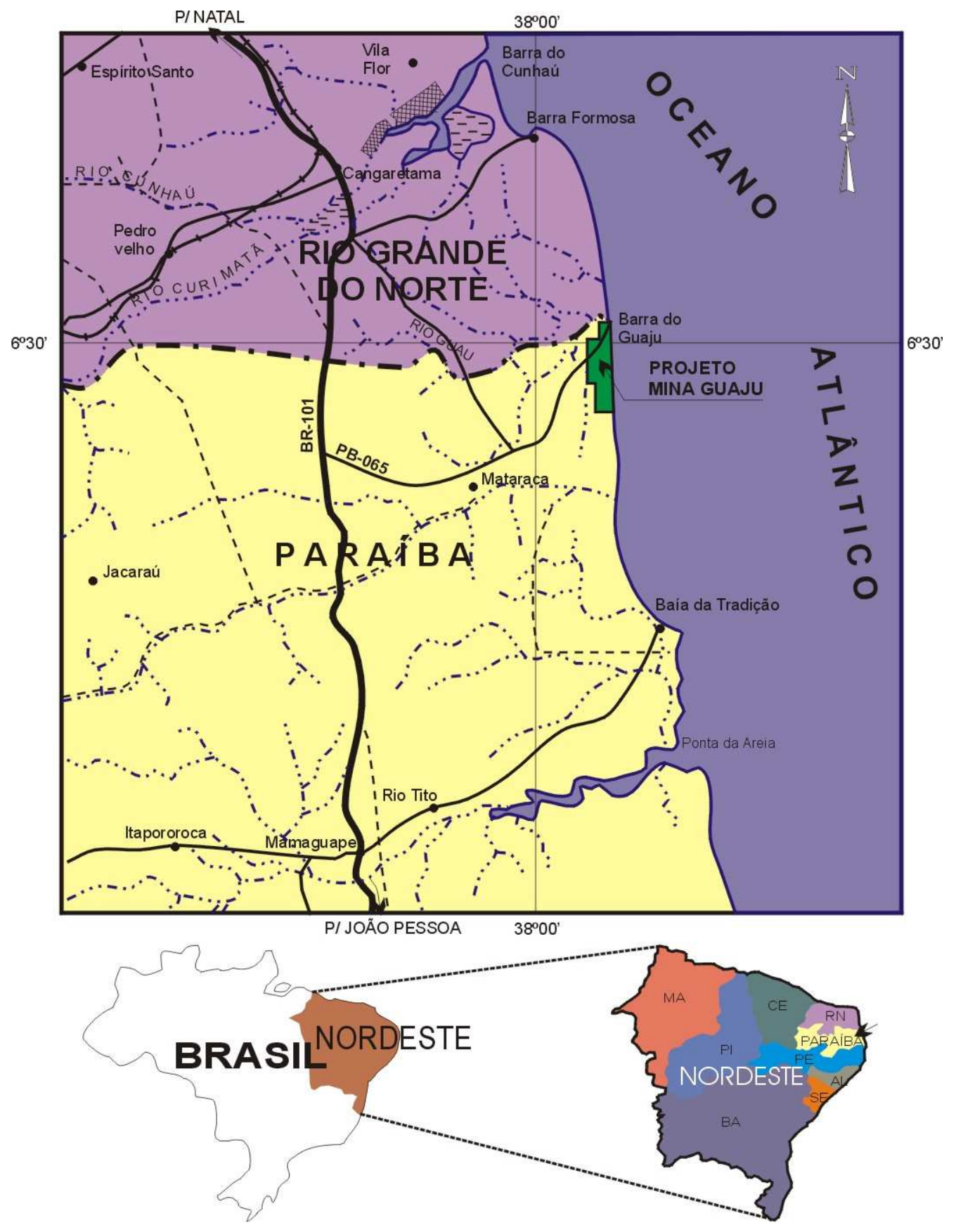

Fonte: informação pessoal ${ }^{8}$

Figura 4 - Localização da área de estudo - Mina do Guaju.

8 Figura fornecida pelo Setor de Meio Ambiente da Mina do Guaju - Lyondell Chemicals Company, em 22 de novembro de 2002. 


\subsection{2 Área do projeto Mina do Guaju}

A área do Projeto Mina do Guaju perfaz uma superfície de 1.123,6 ha. Englobam a área de lavra, que tem os mesmos limites da área de pesquisa, e a área de servidão, locada em terrenos contínuos fora das limitações da área de lavra.

A área de lavra abrange uma superfície de 1.000 ha, e a área de servidão abrange $1.236 \mathrm{Km}^{2}$, das quais fazem parte as instalações fabris de beneficiamento, oficinas, almoxarifados, edifícios para administração, escritórios, laboratórios e alojamento. Fazem parte também da área de servidão, os depósitos de minérios beneficiados, conforme podemos observar no ANEXO A (informação pessoal) ${ }^{9}$.

\subsubsection{Histórico}

A Millennium Chemicals do Brasil S.A., empresa do Grupo Lyondell Chemicals Company, foi fundada, na Bahia, em 25 de janeiro de 1966 com razão social RIB - Rutilo e Ilmenita do Brasil S.A., possui como principal objetivo a produção de pigmento branco de dióxido de titânio.

Com o intuito de suprir as importações brasileiras de ilmenita, no início da década de 70, a Empresa realizou uma pesquisa mineral no litoral brasileiro, quando delimitou algumas áreas-alvo. Devido à presença de alto teor de minerais pesados, em 1972, foi requerida ao DNPM uma área de 1000 ha, localizada na costa nordeste, litoral norte do Estado da Paraíba. Em 1978, foram concedidos a autorização de lavra de ilmenita, zirconita e rutilo, naquela área.

A Millennium Chemicals - PB, única mina na América Latina que produz o minério ilmenita extraída de dunas de areia, começou a operar em 1983 com 50\% de sua capacidade atual. No final da década de 80 , deu início à produção de rutilo e zirconita, e, no final da década de 90 , à produção de cianita (informação pessoal) ${ }^{10}$.

\footnotetext{
9 Dados fornecidos pelo Setor de Meio Ambiente da Mina do Guaju - Lyondell Chemicals Company, em 22 de novembro de 2002.

${ }_{10}$ Dados fornecidos pelo Setor de Meio Ambiente da Mina do Guaju - Lyondell Chemicals Company, em 22 de novembro de 2002.
} 
Com a finalidade de iniciar o processo de recuperação ambiental e atender às exigências legais, em 1987 houve a contratação de técnicos do Departamento de Ciências Florestais da Escola Superior de Lavras (UFLA-MG). Elaborou-se um projeto de recuperação ambiental das pilhas de rejeito da Mina-Guaju (TEIXEIRA; ROSADO; OLIVEIRA-FILHO, 1987), o qual se mantém até a atualidade através de trabalhos de acompanhamento que são desenvolvidos na Empresa.

A implantação dos estudos pioneiros de recuperação ambiental na Mina do Guaju teve início em 1987, logo após a geração do primeiro montante de rejeito gerado pelo processo de beneficiamento dos minérios. Foram gerados nessa primeira fase experimental cerca de 1650 metros cúbicos de rejeito que foram depositados em uma área reservada fora da área de lavra (Figura 5). (informação pessoal) ${ }^{11}$

A principal finalidade desses primeiros estudos foi propor a experimentação de um conjunto de técnicas capazes de fixar e dar início à recuperação das áreas das pilhas de rejeito, por métodos de revegetação. A recuperação seria feita através de um plantio de espécies vegetais capazes de tolerar as condições adversas e que pudessem se estabelecer na área em um menor espaço de tempo. O desenvolvimento do projeto objetivou a definição de vários parâmetros técnicoagronômicos que serviram de base para os trabalhos de recomposição vegetal das novas pilhas de rejeito.

Em setembro de 1989, atendendo às exigências dos órgãos ambientais competentes, foi apresentado a SUDEMA (Superintendência de Administração do Meio Ambiente da Paraíba) o primeiro Plano de Recuperação de Áreas Degradadas (PRAD), (TEIXEIRA; FONSECA, 1989), o qual vem sendo executado com constantes adaptações baseadas em pesquisas, de forma a aprimorar, cada vez mais, todo o processo.

O PRAD apresenta, de maneira sucinta, toda a seqüência de trabalhos executados no processo de recuperação das dunas mineradas. Pretendendo a recuperação do potencial biótico da área e a melhoria das condições estéticas da paisagem que vem sendo alcançado através da reconstituição de novas dunas, modelando o relevo de forma a construir novamente uma paisagem bastante semelhante à original, e através da implantação de uma cobertura vegetal perene,

${ }^{11}$ Dados fornecidos pelo Setor de Meio Ambiente da Mina do Guaju - Lyondell Chemicals Company, em 22 de novembro de 2002. 
desenvolvida com espécies nativas que permitam a fixação das massas arenosas (Figura 6) (informação pessoal) ${ }^{12}$.

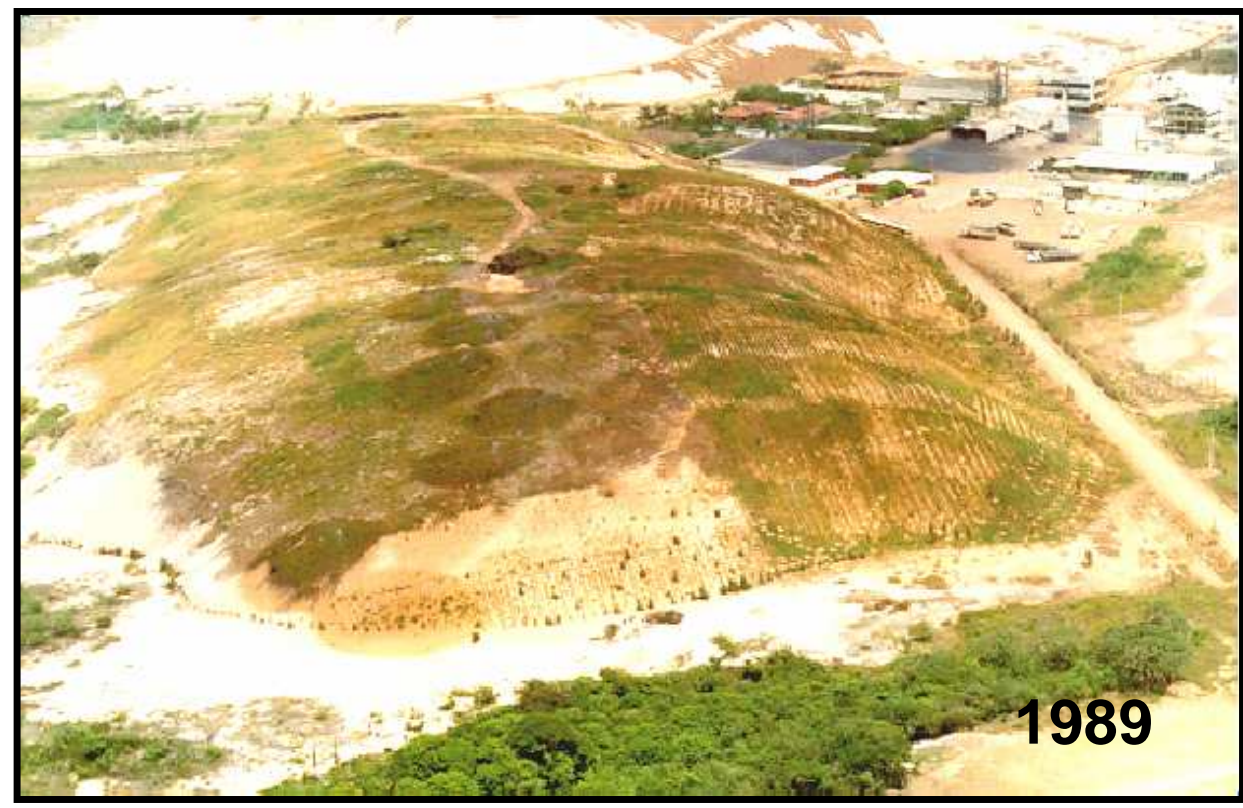

Fonte: informação pessoal ${ }^{13}$

Figura 5 - Primeira pilha de rejeito no início do processo de recuperação - estudos pioneiros de recuperação ambiental em 1989.

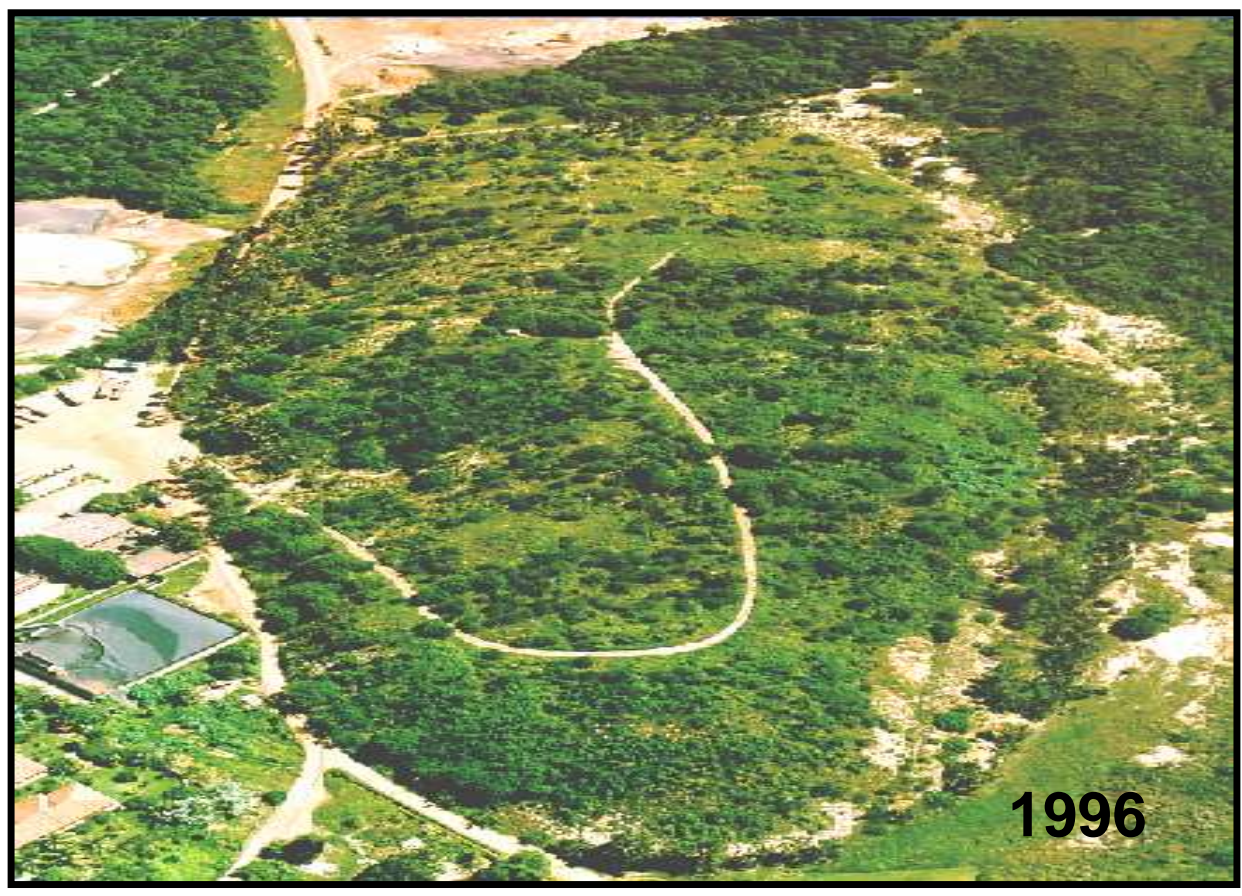

Fonte: (informação pessoal) ${ }^{14}$

Figura 6 - Primeira pilha de rejeito com sete anos de desenvolvimento do processo de recuperação, 1996.

${ }_{12}$ Dados fornecidos pelo Setor de Meio Ambiente da Mina do Guaju - Lyondell Chemicals Company, em 22 de novembro de 2002.

${ }^{13},{ }^{14}$ Fotos fornecidas pelo Setor de Meio Ambiente da Mina do do Guaju - Lyondell Chemicals Company, em 22 de novembro de 2002. 
Em 1992, também por exigência da SUDEMA, foi elaborado o primeiro Plano de Controle Ambiental (PCA) e atualizado o Plano de Recuperação de Áreas Degradadas (DOTE SÁ et al., 1993), os quais foram analisados e posteriormente aprovados pelo Conselho de Proteção Ambiental da Paraíba (COPAM).

A partir daí, a Superintendência passa a determinar a necessidade da Empresa em manter um Programa de Controle e Monitoramento Ambiental (PCA), sendo necessária a apresentação de relatórios técnicos semestrais de acompanhamento das atividades de controle ambiental e recuperação das áreas degradadas pela mineração, a fim de atender a todas as condições preestabelecidas (informação pessoal) ${ }^{15}$.

Pretendendo atender a estas exigências, vários trabalhos foram executados na área da empresa, através de acessorias dadas por docentes da Escola Superior de Agricultura de Lavras (ESAL) e consultores técnicos. Esses trabalhos geraram e ainda geram relatórios técnicos de acompanhamento dos Planos de Controle Ambiental e Plano de Recuperação de Áreas Degradadas da empresa. Dentre estes trabalhos, podemos citar ZANZINI (1993); DOTE SÁ et al. (1994a); DOTE SÁ et al. (1994b); ROSADO et al. (1994); FONSECA et al. (1995a); FONSECA et al. (1995b); ROSADO, CUNHA e SANTOS (1995); FONSECA et al. (1996); ROSADO (1996); ROSADO, SANTOS e CUNHA (1996a); ROSADO, SANTOS e CUNHA (1996b); CUNHA (1997a); CUNHA (1997b); FONSECA et al. (1997a); FONSECA et al. (1997b); ROSADO e CUNHA (1997); CUNHA et al. (1998a); CUNHA et al. (1998b); FONSECA (1998); CUNHA et al. (1999a); CUNHA et al. (1999b); CUNHA et al. (2000a); CUNHA et al. (2000b); CUNHA et al. (2001a); CUNHA et al. (2001b).

Juntamente com os trabalhos desenvolvidos internamente na Lyondell Chemicals Company - Mina do Guaju, vários outros trabalhos que demonstram o sucesso das técnicas adotadas para a recuperação das pilhas de rejeito começaram a ser publicados, como é o caso de TEIXEIRA e FONSECA (1992); OLIVEIRA FILHO e CARVALHO (1993a); OLIVEIRA FILHO (1993); TEIXEIRA e FONSECA (1995); e ALVARENGA, ROSADO e SIQUEIRA (1996), os quais analisam, descrevem e classificam a florística e fisionomia da vegetação no extremo norte do litoral da Paraíba. Além desses também foram publicados trabalhos relacionados

${ }^{15}$ Dados fornecidos pelo Setor de Meio Ambiente da Mina do Guaju - Lyondell Chemicals Company, em 22 de novembro de 2002. 
com a avaliação do nível de recuperação das pilhas de rejeito, através de estudos da recomposição da cobertura vegetal (OLIVEIRA FILHO; CARVALHO, 1993b), estudos de levantamentos preliminares de formigas (ZANZINI et al., 1994), avaliação da vegetação herbáceo-arbustiva (SANTOS et al., 1997a) e estudos desenvolvidos com fungos micorrízicos (SANTOS et al., 1997b).

Além dos trabalhos acadêmicos de graduação e pós-graduação desenvolvidos por BARROSO (1994), com estudos de alguns atributos químicos e físicos dos substratos utilizados no processo de estabilização de pilhas de rejeito; MIRANDA (1994), desenvolvendo estudos com vegetação e bancos de sementes; DOTE SÁ (1995), caracterizando a mineração de ilmenita, zirconita e rutilo no sistema natural litorâneo; CUNHA (1995), abordando a recuperação de áreas degradadas pela Mina Guaju; SANTOS (1996), avaliando a recomposição vegetal das pilhas de rejeito e inter-relacionando-a com as propriedades físicas, químicas, bioquímicas e microbiológicas do solo; CUNHA (1997a), que avalia os aspectos técnicos e econômicos do processo de recuperação das dunas litorâneas; e DOTE SÁ (1998), analisando os impactos, compatibilização e recuperação no sistema deposicional litorâneo na área da Mina do Guaju.

Avaliações efetuadas indicaram que, no ano de 2002, houve uma tendência à redução do teor do minério. Esse fato, associado aos crescentes custos do atual método de lavra, obrigou a empresa a uma reavaliação desse método (Escavação mecanizada a seco). Foram então identificadas possibilidades de tecnologias avançadas, aplicadas atualmente em outros países que possuem menores consumo de energia e baixos impactos ambientais, o que garantiu a lavra também em áreas com teores reduzidos de minério (CUNHA et al., 2001b).

\subsubsection{Método de lavra e recomposição do relevo}

Desde que entrou em atividade em 1983 até 2002, a Mina do Guaju teve seu desenvolvimento baseado no método de escavação mecanizada a seco. Em novembro de 2002 entrou em operação o método de lavra por dragagem. Essa mudança teve como objetivo tornar econômica a porção oeste da jazida, onde 
ocorrem teores mais baixos de minério, em função da maior capacidade nominal de lavra da draga em relação ao método de escavação a seco (informação pessoal) ${ }^{16}$.

\subsubsection{Escavação mecanizada a seco}

O método para extração de minério na escavação mecanizada a seco na Mina do Guaju é baseado na formação de bancadas simples, que são desmontadas por tratores que empurram a areia mineralizada até a borda da bancada, a areia desce por gravidade até a moega de calhas vibratórias (Figura 7). São normalmente mantidas duas frentes de lavra em operação, sendo que uma terceira frente de lavra está sempre disponível para eventuais paralisações (DOTE SÁ, 1998).

Depois das calhas vibratórias, o minério é transportado por correias transportadoras fixas e móveis até a usina de beneficiamento (Figura 8) (RÉ; MARQUES, 2002). Nesta usina ocorre o processo de separação dos minerais pesados por via úmida. Os minerais leves que formam o rejeito da usina, são devolvidos ao ambiente, mais especificamente, às áreas já lavradas, para recomposição do relevo de dunas (Figura 9).

${ }^{16}$ Dados fornecidos pelo Setor de Meio Ambiente da Mina do Guaju - Lyondell Chemicals Company, em 22 de novembro de 2002. 


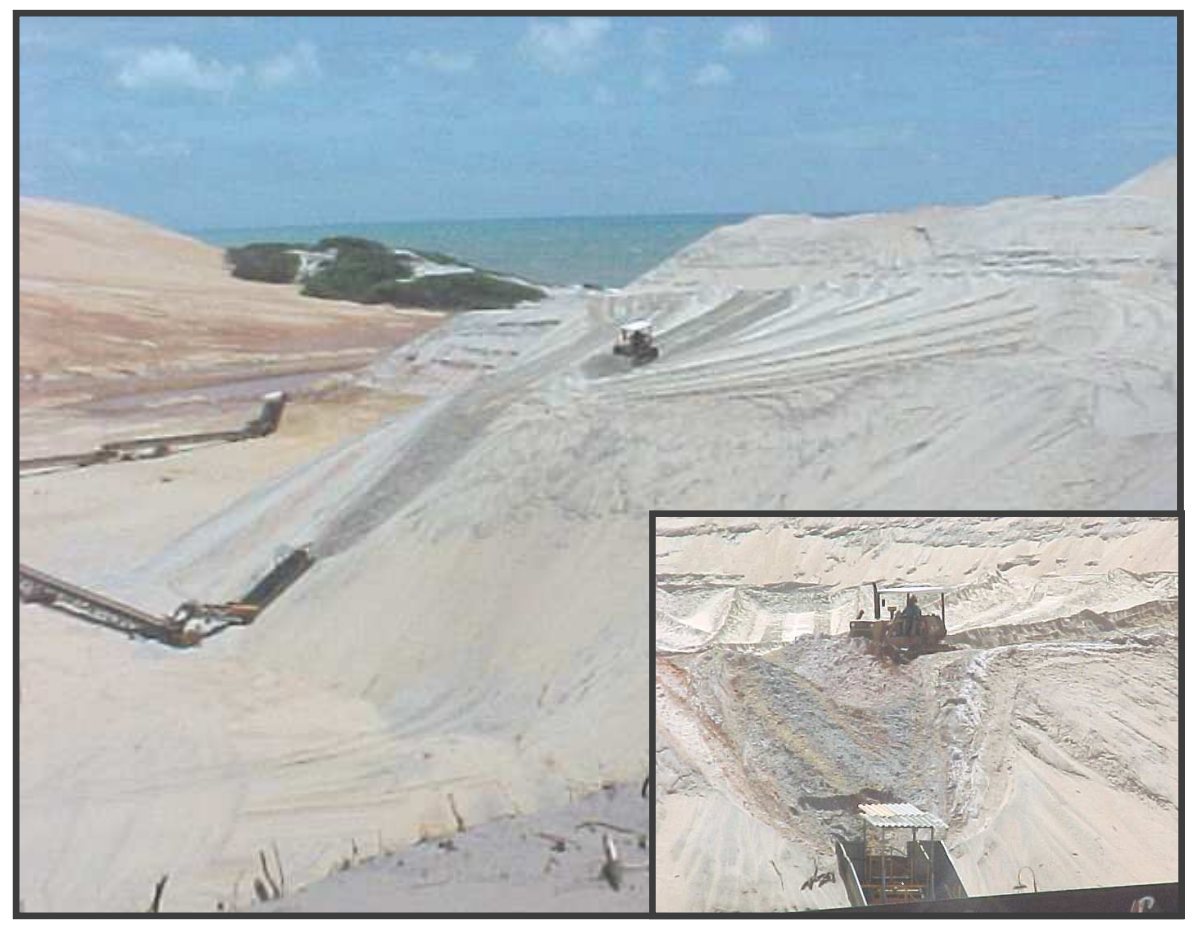

Fonte: informação pessoal ${ }^{17}$

Figura 7 - Vista do sistema de lavra: escavação mecanizada a seco.

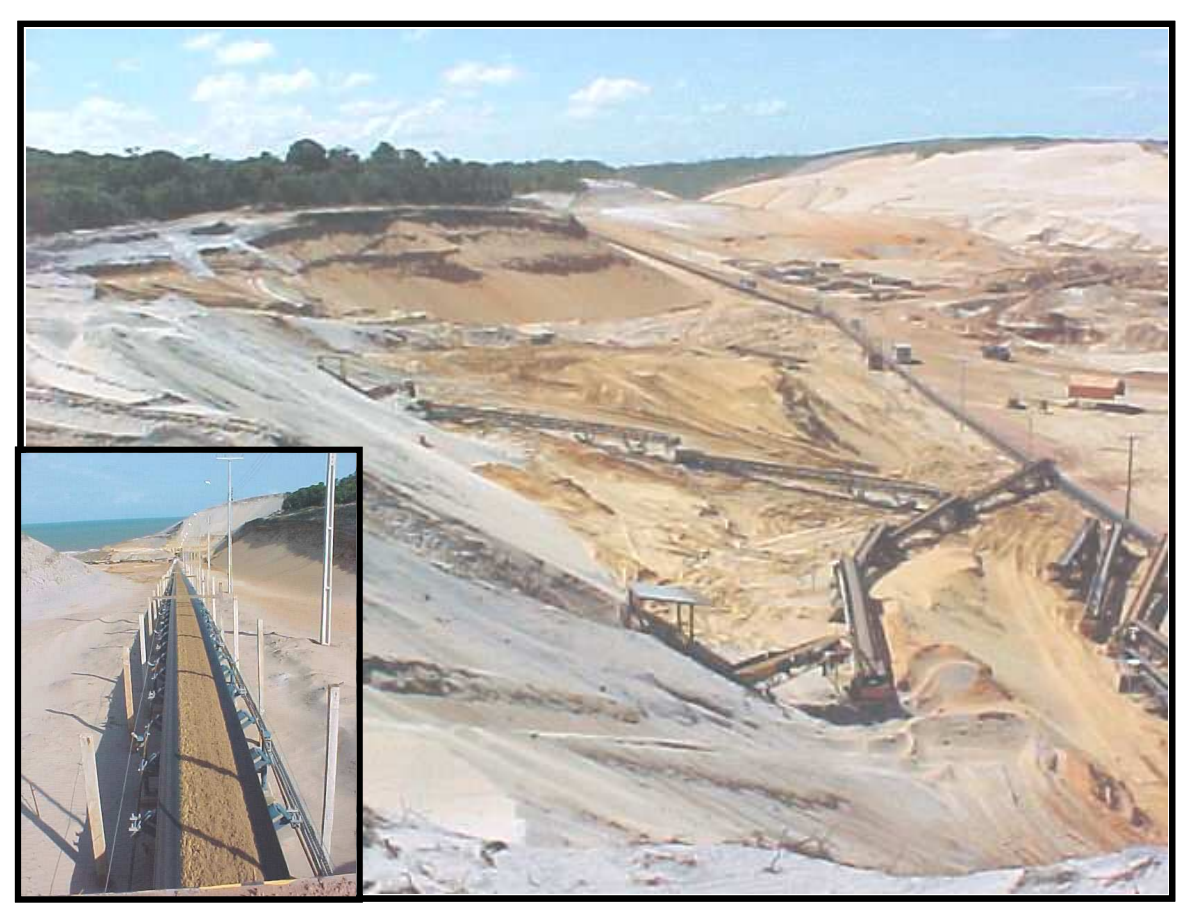

Fonte: informação pessoal ${ }^{18}$

Figura 8 - Detalhe da correia transportadora do sistema de lavra.

17, 18 Fotos fornecidas pelo Setor de Meio Ambiente da Mina do Guaju - Lyondell Chemicals Company, em 22 de novembro de 2002. 


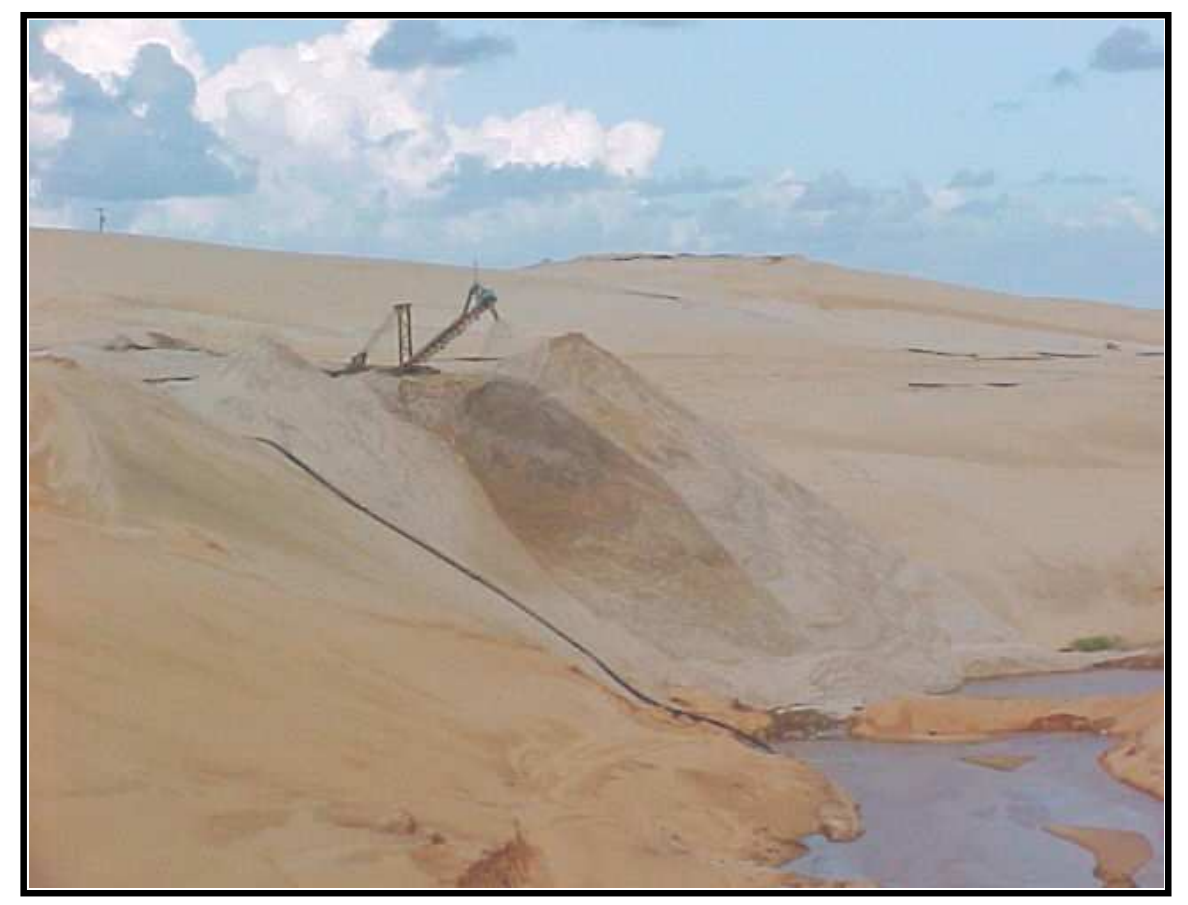

Fonte: informação pessoal ${ }^{19}$

Figura 9 - Processo de reconstituição de dunas, a partir da disposição da pilha de rejeito na área já lavrada.

${ }^{19}$ Foto fornecida pelo Setor de Meio Ambiente da Mina do Guaju - Lyondell Chemicals Company, em 22 de novembro de 2002. 
Na Figura 10, pode-se observar um desenho esquemático da escavação mecanizada a seco.

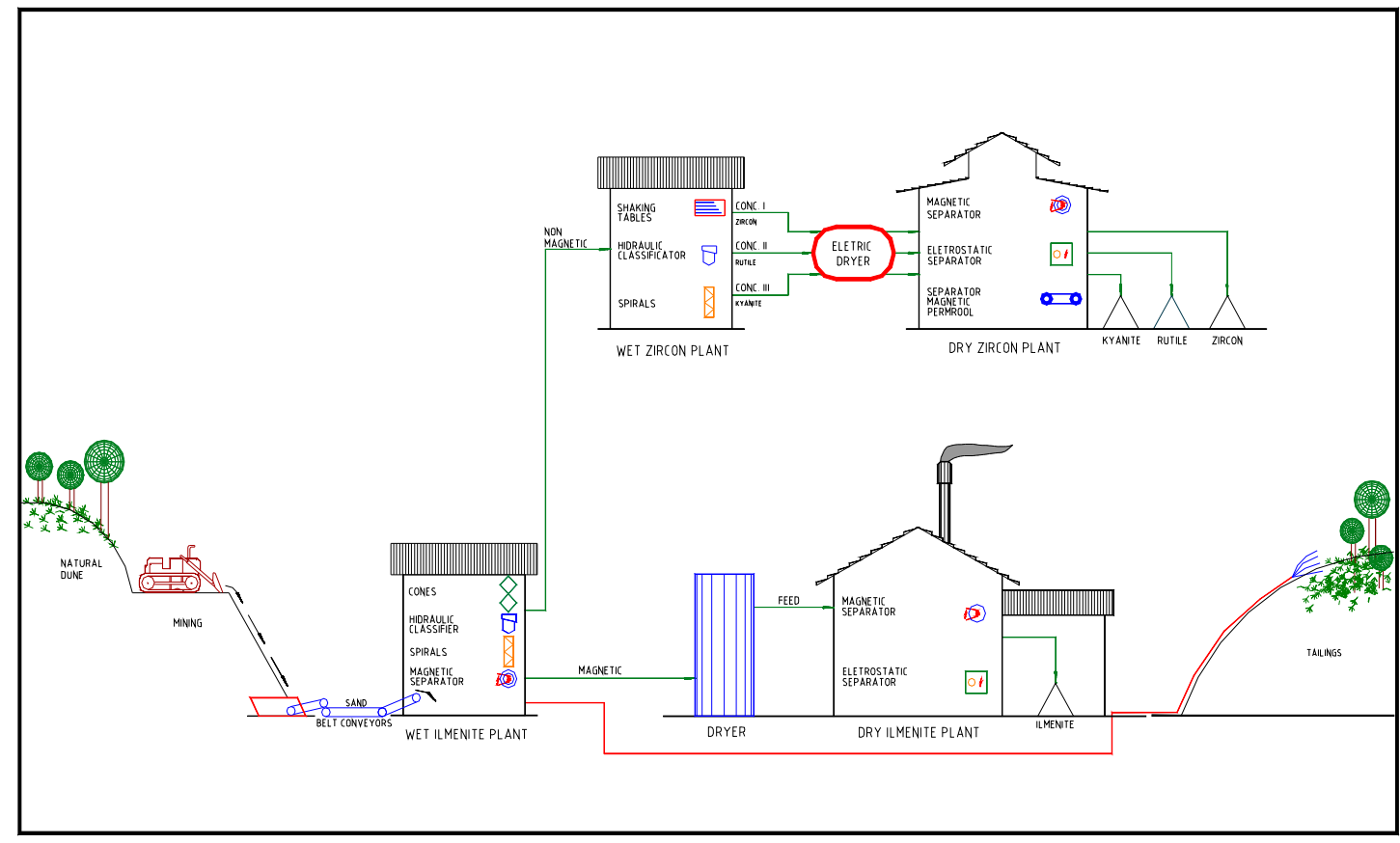

Fonte: informação pessoal ${ }^{20}$

Figura 10 - Desenho esquemático da lavra mecanizada a seco.

Cerca de 3 a $4 \%$ de todo o material lavrado representam os principais recursos minerais explorados, dentre eles a IImenita $\left(\mathrm{FeTiO}_{3}\right)$, Zirconita $\left(\mathrm{ZrSiO}_{4}\right)$, Rutilo (TiO2), e Cianita $\left(\mathrm{Al}_{2} \mathrm{SiO}_{5}\right)$, sendo grande porcentagem constituído por areia quartzosa (cerca de 96\%). Entre o ano de 1983 e junho de 2002, foram lavrados cerca de 66.288 .000 toneladas de minérios com teor médio de $3,73 \%$ de minerais pesados, com uma produção de cerca de 2.474 .000 toneladas desses minerais (informação pessoal) $^{21}$.

A produção anual de ilmenita, zirconita, rutilo e cianita podem ser observados na Tabela 4.2.

20 Desenho esquemático fornecido pelo Setor de Meio Ambiente da Mina do Guaju - Lyondell Chemicals Company, em 22 de novembro de 2002.

${ }_{21}$ Comunicação verbal fornecida pelo geólogo Emerson Ricardo Ré do Setor de Planejamento da Mina do Guaju - Paraíba, em 20 de abril de 2003. 
Tabela 4.2 - Produção de minerais pesados na Mina do Guaju.

\begin{tabular}{ccccccc}
\hline PRODUTOS & $\mathbf{1 9 9 8}(\mathbf{t})$ & $\mathbf{1 9 9 9}(\mathbf{t})$ & $\mathbf{2 0 0 0}(\mathbf{t})$ & $\mathbf{2 0 0 1}(\mathbf{t})$ & jun/02 (t) & $\begin{array}{c}\text { Acumulado 1983 } \\
\text { a Jun/2002 (t) }\end{array}$ \\
\hline ILMENITA & $102.993,90$ & $112.931,70$ & $97.377,80$ & $95.510,10$ & $50.612,60$ & $1.501 .964,00$ \\
ZIRCONITA & $16.515,30$ & $18.112,60$ & $18.124,20$ & $17.030,00$ & $10.491,40$ & $213.449,70$ \\
RUTILO & $1.860,70$ & $2.125,10$ & $2.433,20$ & $1.790,90$ & 895,9 & $25.597,00$ \\
CIANITA & 241,9 & 134,7 & 501,8 & 420,1 & 137,9 & $1.436,40$ \\
\hline & & & & & Fonte: informação pessoal
\end{tabular}

A lavra mecanizada a seco deverá ser paralisada devido ao esgotamento das áreas com teores econômicos que justificam esse método.

\subsubsection{Lavra por dragagem}

Com a capacidade nominal três vezes superiores ao método da lavra mecanizada a seco, o método de lavra por dragagem permite lavra economicamente viável a porção oeste da jazida. Este método compreende uma draga de roda de caçambas, acoplada a um silo flutuante e uma usina de concentração flutuante cativa, operando em um lago artificial que se desloca com o avanço da lavra. Por este motivo, a distância entre a draga e a usina flutuante, e entre esta e a pilha de rejeito, apresentam-se praticamente constantes, eliminando a necessidade de bombeamento e transporte de minério por longas distâncias.

Em relação ao processo de recuperação das pilhas de rejeito, os efeitos diferenciais sobre a flora ou fauna através do novo método de lavra serão mínimos. Um distúrbio pontual foi ocasionado apenas em função da necessidade de aumento da área desmatada na fase de implantação do projeto. Este distúrbio, porém, não apresenta efeitos diferenciais no contexto global da fase de operação. Assim, considerando as diferenças entre os métodos de lavra mecanizada a seco e o proposto, pode-se afirmar que o balanço dos efeitos ambientais é positivo e 0 investimento é compensatório (RÉ; MARQUES, 2002).

${ }^{22}$ Dados fornecidos pelo Setor de Meio Ambiente da Mina do Guaju - Paraíba - Lyondell Chemicals Company, em 20 de abril de 2003. 
Na Figura 11 observa-se uma ilustração esquemática do método de lavra por dragagem proposto para a Mina do Guajú.

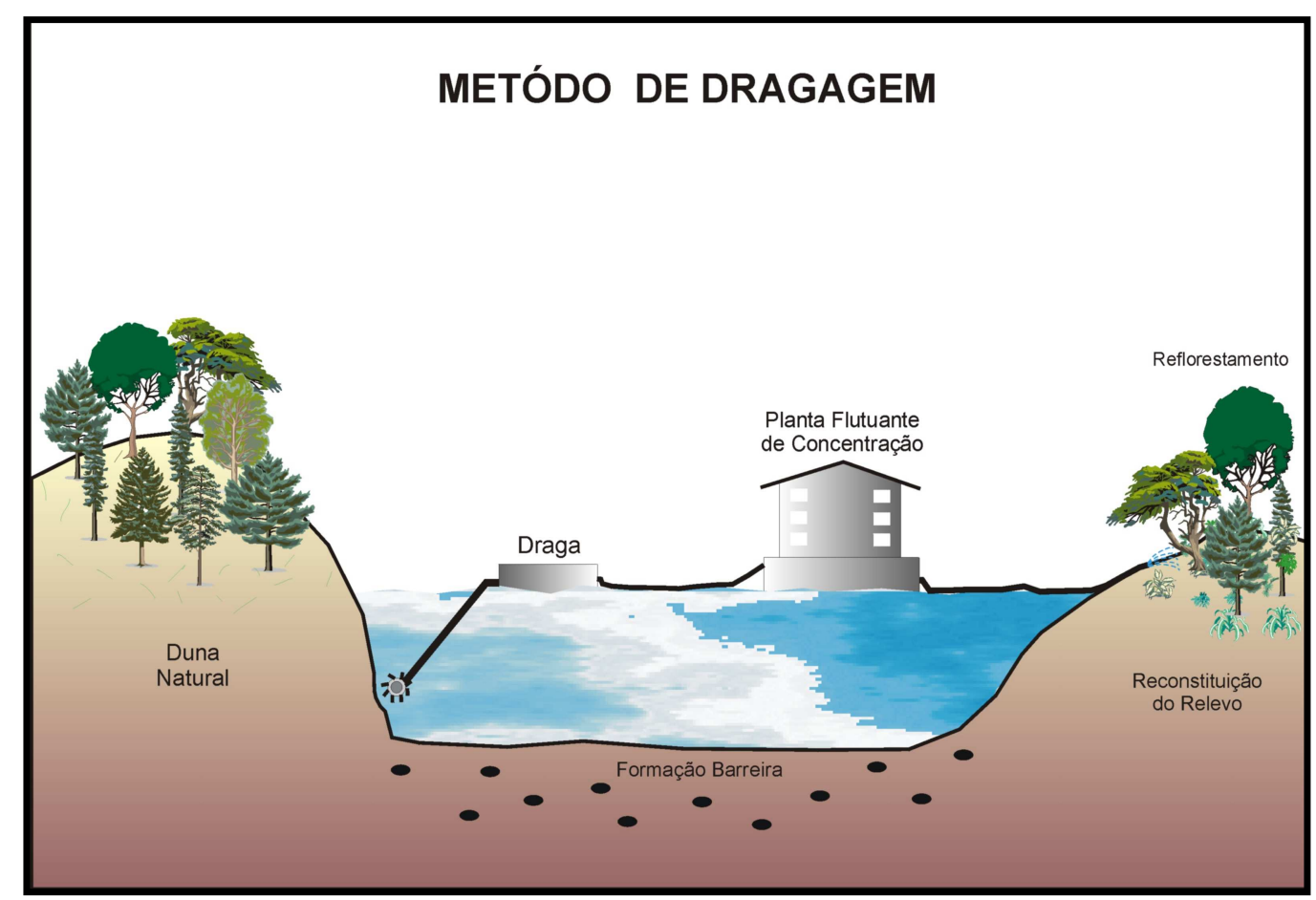

Fonte: informação pessoal ${ }^{23}$

Figura 11 - Desenho esquemático da lavra com método de dragagem.

\subsubsection{Caracterização ambiental da área}

Os dados apresentados a seguir são baseados nos documentos intitulados "Plano de Controle Ambiental - Atualização do Plano de Recuperação de Áreas Degradadas - Projeto Mina do Guaju", elaborado pela Geominas Consultoria e Projetos, em dezembro 1992, para instruir o processo de licenciamento ambiental do empreendimento (DOTE SÁ et al., 1993).

23 Desenho esquemático fornecido pelo Setor de Meio Ambiente da Mina do Guaju - Lyondell Chemicals Company, em 22 de novembro de 2002. 


\subsubsection{O meio físico}

\subsection{Clima}

O litoral do Nordeste brasileiro caracteriza-se por um clima tropical úmido (quente e úmido), com estação seca no verão e chuvosa no inverno (DOTE SÁ et al., 1993). A precipitação pluviométrica média na região fica em torno de $1684 \mathrm{~mm}$ de chuva anual, concentrando-se em $82,54 \%$ nos meses de março a agosto, sendo os meses mais chuvosos os de abril a julho (Tabela 4.3). A umidade relativa está entre os $90 \%$, no período de inverno, e no verão com $67 \%$ aproximadamente. Os fatores climáticos, a princípio, não representam restrição para as atividades de lavra e recuperação ambiental, desde que observadas as épocas ideais para cada tipo de operação.

A temperatura média compensada mostra na região praiana do Nordeste valores mínimos de $25,4^{\circ} \mathrm{C}$, em julho; e máximos de $28,8^{\circ} \mathrm{C}$, em novembro. As temperaturas máximas são de $32,0^{\circ} \mathrm{C}$, registradas em novembro e dezembro, e a temperatura mínima é de 20,8ㄷ registrada em julho e agosto (DOTE SÁ et al., op.Cit.).

Tabela 4.3 - Média mensal dos índices pluviométricos coletados entre 1996 e 2001.

\begin{tabular}{cccccccc}
\hline & $\mathbf{1 9 9 6}$ & $\mathbf{1 9 9 7}$ & $\mathbf{1 9 9 8}$ & $\mathbf{1 9 9 9}$ & $\mathbf{2 0 0 0}$ & $\mathbf{2 0 0 1}$ & MÉDIA \\
\hline JAN & 28 & 7,5 & 123 & 66 & 141,9 & 24,2 & 65,10 \\
FEV & 92,8 & 92,5 & 65 & 83,5 & 145,7 & 11,6 & 81,85 \\
MAR & 317 & 174 & 124 & 163,5 & 178,4 & 150 & 184,48 \\
ABR & 412,7 & 373 & 115 & 117,5 & 274,3 & 391,78 & 280,71 \\
MAI & 135,8 & 363 & 210,5 & 393,2 & 313,1 & 55,5 & 245,18 \\
JUN & 192,2 & 59,5 & 409,5 & 171 & 625,5 & 332 & 298,28 \\
JUL & 134,4 & 130 & 335,5 & 101,6 & 523,75 & 155,2 & 230,08 \\
AGO & 158,5 & 123 & 161,5 & 67 & 277,55 & 122,5 & 151,68 \\
SET & 76,5 & 0 & 25,5 & 30 & 219,2 & 64 & 69,20 \\
OUT & 20,6 & 0 & 0 & 44,5 & 28 & 12,5 & 17,60 \\
NOV & 45,1 & 2,7 & 23,5 & 1,2 & 38,4 & 4,8 & 19,28 \\
DEZ & 12 & 35,4 & 33,5 & 51,8 & 67,3 & 45,7 & 40,95 \\
\hline
\end{tabular}

Fonte: informação pessoal ${ }^{24}$

\footnotetext{
${ }^{24}$ Dados fornecidos pelo Setor de Meio Ambiente da Mina do Guaju - Paraíba - Lyondell Chemicals Company, em 22 de novembro de 2002.
} 


\subsection{Geologia}

A área de estudo compreende a faixa litorânea da porção mais setentrional do Estado da Paraíba. A sua constituição geológica é essencialmente sedimentar, representada por sedimentos areno-argiloso tércio-quaternário de idade pliopleistocênica (2Ma), pertencentes ao Grupo Barreiras e sedimentos arenosos de idade recente (areias de praia, dunas semifixas, aluviões e mangues).

O Grupo Barreiras ocorre em forma de tabuleiros, com suave inclinação em direção ao mar e afloram, dentro da área de estudo, no entalhamento do Rio Guaju e com maior intensidade sob o campo de dunas. Está representado pela Formação Guararapes e por sedimentos pouco consolidados, com grau diagenético fraco, composto de conglomerados arcosianos, arcósios e arenitos finos a grosseiros, mal classificados. A estratificação varia de mal definida a boa e as cores dominantes variam entre o vermelho, o castanho e o ocre (DANTAS, 1982).

Os sedimentos quaternários estão representados pelas areias de praia, aluviões, mangues, dunas semifixas e fixas. Principalmente nas dunas fixas são detectadas as mineralizações titano-zirconíferas da Mina do Guaju. As dunas são formadas por areias eólicas de granulometria fina, bem classificadas, com grãos arredondados e esféricos, apresentando coloração clara e estratificação cruzada eólica, definido por finos níveis silto-argilosos. As dunas encontram-se sobrepostas ao Grupo Barreiras (DOTE SÁ, 1998).

Segundo BESSA (1975) os minerais pesados da região de Mataraca foram formados por intemperização físico-química de rochas de granulação fina, preservando os minerais pesados e quartzo, que, devido à alta resistência foram transportados pelos rios da região e depositados primeiramente nas fáceis marinhas próximas ao Grupo Barreiras, e posteriormente a esta primeira deposição, ficaram expostos pelo efeito do soerguimento da crosta terrestre, resultando na erosão que persiste até a atualidade.

Dessa forma, os minerais pesados foram novamente carreados para o mar e pela ação das marés, distribuídos pelas praias. $O$ transporte desses minerais para 0 continente se deu pela exposição direta à ação dos fortes ventos alísios, formando as dunas que recobrem a região. 
A seguir, na Figura 12, observa-se o mapa geológico parcial da Paraíba (DANTAS, 1982).

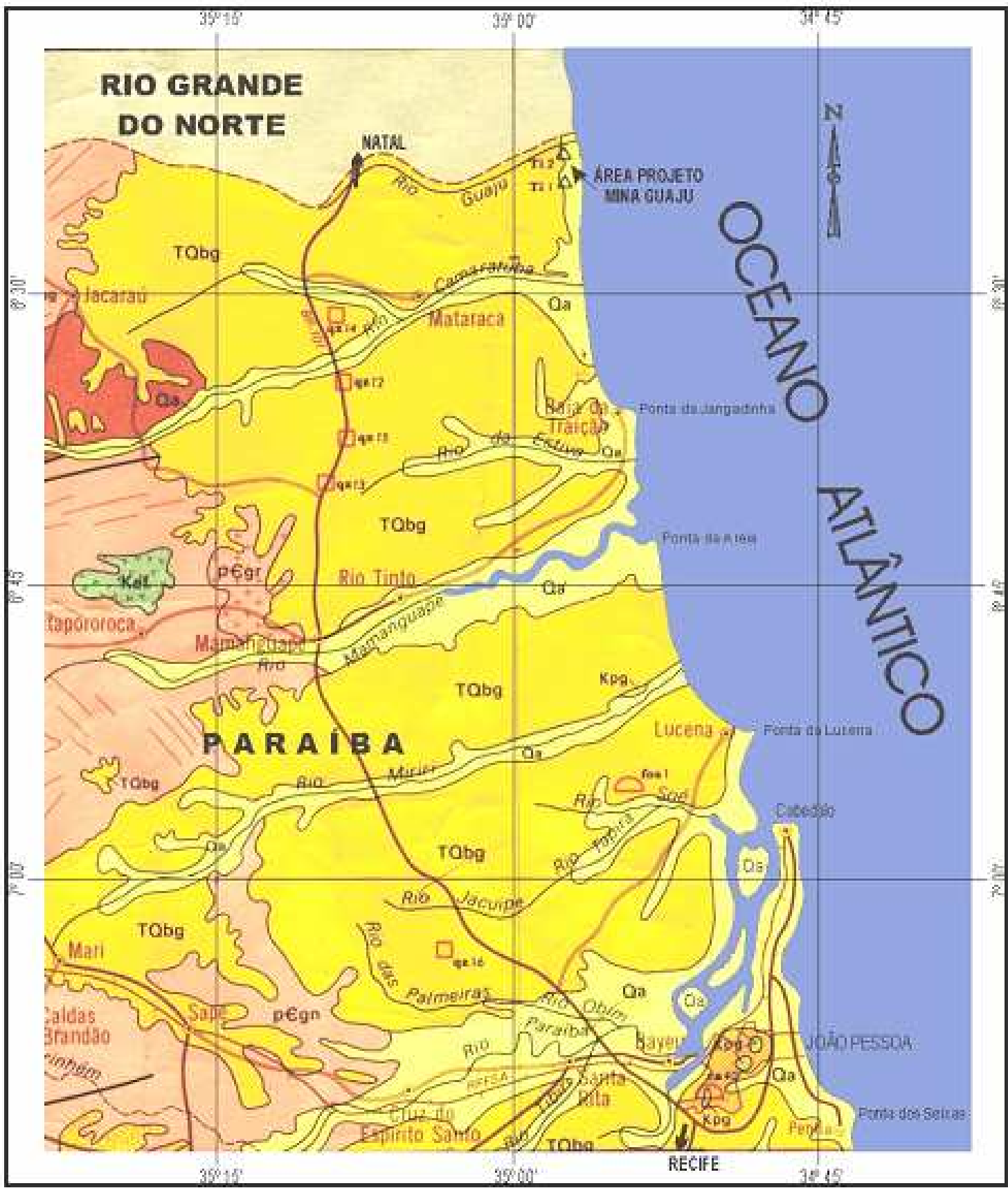

Legenda: Unidades Litoestratigráficas: $\mathbf{Q a}=$ Aluviões, Dunas, Sedimentos de praia, etc.; $\mathbf{T Q b g}=$ Grupo Barreiras: Formação Guarapes - argilas variegadas, arenitos, cascalhos.; Kpg = Grupo Paraíba: Formação Gramame - calcário margoso, marga e argila com calcarenito, arenito, fosforito na base.; Kef = Rochas Efusivas Ácidas; pEAss = Grupo Seridó - Biotita -xisto, biotito-xisto granatífero, biotita-xisto com granada e/ou silimanita, cordierita, estaurolita, andalusita, localmente feldspáticos; pEgn = Complexico Gnássico - Migmatito, incluindo rochas granitóides; $(p E g r)=$ Granitos, Granodioritos, Tonalitos, Monzonitos.

Fonte: DANTAS et al (1982), escala 1/500.000.

Figura 12 - Compartimentação Geológica Regional. Compilação de parte do mapa geológico da Paraíba. 


\subsection{Geomorfologia}

Geomorfologicamente, dentro do contexto nordestino pode-se dividir a região nas unidades de "Planícies Litorâneas" e "Campos de Dunas". A primeira ocupando a zona de praia propriamente dita e o mangue; e a segunda, o grande cordão dunar, que em quase todo o Nordeste se estende ao longo da costa.

As dunas, objeto principal da lavra devido à sua elevada concentração de minerais pesados, especialmente ilmenita $\left(\mathrm{FeTiO}_{3}\right)$, zirconita $\left(\mathrm{ZrSiO}_{4}\right)$ e rutilo $\left(\mathrm{TiO}_{2}\right)$, são caracterizadas pela sua constante orientação de aproximadamente $\mathrm{N} 40^{\circ} \mathrm{W}$, porte elevado - chegando acima de 80 metros de altura, extensão de cerca de 6,5Km e largura máxima de 1,8Km (DOTE SÁ et al., 1993).

Assim, segundo OLIVEIRA-FILHO e CARVALHO (1993b), o relevo formado acima do nível do mar estende-se em uma faixa estreita de terraço arenoso, sucedidos pelas encostas inclinadas das dunas, com altitudes elevadas (50 e $80 \mathrm{~m}$ ). Da crista dessas dunas para o interior as encostas se tornam mais suaves e conduzem às planícies arenosas e levemente onduladas.

\subsection{Solos}

$\mathrm{Na}$ área de estudo foram individualizadas as seguintes classes de solo (DOTE SÁ et al., 1993):

$\mathrm{AMd}_{1}$ - Areias Quartzosas Marinhas distróficas (planícies)

É composto pelas areias de origem marinha, depositada pela ação dos ventos. São solos profundos ou muito profundos, não hidromórficos, excessivamente drenados. São ácidos e possuem fertilidade natural muito baixa. Não apresentam horizontes diferenciados. Ocorrem na Planície litorânea, relacionado ao relevo plano e suavemente ondulado. 
AMd2 - Areias Quartzosas Marinhas distróficas (dunas)

Estes solos estão relacionados ao relevo ondulado e fortemente ondulado (Campo de dunas); são arenosos, muito profundos, não hidromórficos e excessivamente drenados. São ainda ácidos e de baixa fertilidade natural. Têm seqüência de horizontes $\mathrm{A}$ e $\mathrm{C}$.

> PVd - Podzólico Vermelho-Amarelo distrófico

Ocorrem no relevo plano ou suavemente ondulado, sobre a Planície pré-litorânea da área de estudo. Em geral, são ácidos e de baixa fertilidade natural e apresentam horizontes diferenciados ( $\mathrm{A}$ e $\mathrm{Bt}$ ). $\mathrm{Na}$ área em questão, esta classe possui textura cascalhenta e características distintivas pelo caráter abrupto plíntico, concrecionário, raso, com fase pedregosa.

$>\mathrm{SM}$ - Solos Indiscriminados de mangues

São solos holomórficos, alagados, de cor escura, pouco diferenciados, com textura indiscriminada, possuindo cobertura vegetal característica de mangue. Diferenciam-se dos solos aluviais pela alta salinidade. Apresentam horizonte $A$ pouco espesso, seguido do $\mathrm{C}$, contendo horizontes sálicos, bem como crostas superficiais de sais cristalizados.

$\mathrm{Na}$ área, objeto de lavra, os solos atingidos, predominantemente, pertence à classe das Areias Quartzosas Marinhas distróficas. Os solos atingidos em geral possuem baixíssima fertilidade natural e estrutura desfavorável. Não possuem, portanto, aptidão agrícola nem condições de uso futuro. Por esse motivo, entre outros de ordem ambiental, o método de recuperação ambiental utilizado na Mina do Guaju visa essencialmente à recomposição da vegetação original, medida que vem sendo executada com sucesso no local afetado, há mais de uma década. 


\subsection{Recursos Hídricos}

A Mina do Guaju está situada na Bacia Hidrográfica do Rio Guaju, à sua margem direita e a cerca de 1,5 Km da foz. A Bacia do Rio Guaju está localizada entre as Bacias do Rio Camaratuba e do Rio Curimataú, tendo como principal curso d'água o rio homônimo, que permanece perene durante todo o ano. Além do Rio Guaju, a rede hidrográfica da área compõe-se de seus afluentes, destacando-se à direita o Rio Coelho e à esquerda o Rio Pau-Brasil (DOTE SÁ et al., 1993).

O Rio Guaju e seus afluentes são alimentados por águas pluviais durante a estação chuvosa e, por águas subterrâneas do Grupo Barreiras e do Campo de Dunas, oferecendo possibilidade de aproveitamento de suas águas. Contudo, a vazão do rio é altamente prejudicada pelo assoreamento de seu leito, fato ocasionado pelos constantes desmatamentos, inclusive de matas ciliares à montante da área do projeto.

$\mathrm{Na}$ área do empreendimento, o Rio Guaju, que possui vazão média anual de $20.000 \mathrm{~m}^{3} / \mathrm{h}$, representa a fonte de abastecimento da água utilizada no processo de beneficiamento mineral, sendo os efluentes líquidos resultantes tratados e redimensionados novamente ao mesmo rio. É importante destacar que, na área do empreendimento da Mina do Guaju, a mata ciliar é composta por um mangue e vegetação de várzea, as quais são totalmente preservadas.

Além da Bacia do Rio Guaju, a drenagem superficial da área é composta por lagos freáticos, os quais recebem contribuição pluviométrica direta no espelho d'água e os influxos das águas subterrâneas. Ocorrem em geral na faixa entre a berma e o campo de dunas, em dimensões variadas: durante a época chuvosa, estas lagoas se interligam formando praticamente um único espelho d'água; enquanto que, na época de estiagem, secam consideravelmente e algumas chegam a desaparecer.

Merecem destaque as Lagoas das Negras e Guaju devido suas dimensões variadas, bem como a Lagoa Salgada devido ao caráter perene, em virtude de sua ligação com o mar (DOTE SÁ et al., 1993). 


\subsubsection{O meio biótico}

4.1.5.2.1 Flora: descrição das formações vegetais existentes

A cobertura vegetal da área de estudo compõe-se de formações distintas, cujo conjunto integra o complexo ambiental litorâneo do Projeto Mina do Guaju. Foram caracterizados oito tipos de formações - restinga praiana, restinga arbustiva, mata de restinga, transição restinga-tabuleiro, tabuleiro, várzea do rio, mangue, formações pioneiras e campos antrópicos (DOTE SÁ et al., 1993).

A seguir, veremos a descrição dos ambientes, os quais se encontram delimitados no ANEXO B.

\section{$>$ Restinga praiana}

Ocorre nas áreas adjacentes à praia e se estende até a encosta das dunas fronteiras ao mar, ocupando uma faixa descontínua de espessura variável de até $400 \mathrm{~m}$.

A cobertura vegetal é de pequeno porte, composta por espécies resistentes ao vento, ao sal e à instabilidade do substrato. Ocorrem principalmente espécies herbáceas como capim-da-praia (Sporobolus virginicus), salsa-da-praia (Ipomoea pés-caprae), capim gengibre (Paspalum maritimum) e fava-de-boi (Canavalia maritima). Estão incluídas neste ambiente as lagoas freáticas (lagunas).

Restinga arbustiva

Ocorre na base da encosta da duna fronteira ao mar e no pós-berma, como mata de retaguarda das dunas semifixas, desenvolvendo um papel importante de contenção destas. 
É constituída por vegetação arbustiva baixa, agrupada em moitas intrincadas, densas e moldadas pelos ventos marinhos. Ocorrem espécies como o guajiru-dapraia (Chrysobalanus icaco), cardeiro-grande (Pilosocereus hapalacanthus) e paubranco (Eugenia cualifolia). Este ambiente é utilizado, pela fauna, como corredor para deslocamento.

Mata de Restinga

Ocorre sobre a encosta marítima e o topo da duna frontal ao mar, sendo constituídas por árvores perenifólias, em geral baixas, tortuosas e muitas vezes perfiladas, com estrato herbáceo pouco denso.

A Mata de Restinga caracteriza-se por ser constituída de espécies importadas de outras formações vegetais, sendo comum a presença de espécies da Mata Atlântica, como sapucaia (Lecythis pisonis); da Caatinga, juazeiro (Ziziphus joazeiro) e do Cerrado, sucupira (Bowdichia virgilioides).

Dentre as principais espécies arbóreo-arbustivas têm-se: maçaranduba (Manilkara salzmanii), peroba (Tabebuia roseo-alba) e louro (Ocotea gardneri). Nas copas e troncos das árvores ocorrem lianas e epífitas em baixa densidade.

> Transição Restinga-tabuleiro

Este ambiente compreende uma faixa entre 40 e 60 metros. Ocorre na vertente continental da duna, em área protegida contra os ventos marinhos. Apresentam estrato arbóreo/arbustivo heterogêneo, formando touceiras, raras herbáceas, com solos geralmente expostos. As touceiras se rarificam à medida que aumenta a cota em direção ao Tabuleiro.

A vegetação é mesclada, com espécies da mata de Restinga e de Tabuleiro, destacando-se o cajueiro (Anacardium occidentale L), pau-mulato (Eugenia sp.) e o pau-ferro (Chamaecrista bahie).

A diversidade faunística deste ambiente é reduzida, tendendo mais para as espécies do Tabuleiro do que da Mata de restinga. 
$>$ Tabuleiro

A área de estudo encontra-se bem representada na porção oeste e centro-norte, sobre o relevo tabular e no topo das dunas da porção central. A vegetação caracteriza-se por árvores e arbustos retorcidos, com estrato herbáceo (gramíneas) contínuo. Ocorrem espécies como mangabeira (Hancornia speciosa), cajueiro-bravo (Curatella americana) e cajueiro (Anacardium occidentale).

Apresenta biodiversidade mínima, tanto para a flora, quanto para a fauna. Este ambiente pode ser considerado como um enclave dentro das áreas de restinga, com espécies típicas e por vezes endêmicas.

\section{Várzea}

A várzea da área de estudo compreende a mata ciliar do rio Guaju. Assenta-se sob um terreno plano sujeito ao alagamento, que se inunda totalmente no período chuvoso, voltando a secar durante a estiagem.

Constitui-se de uma vegetação subarbustiva e herbácea típicas de áreas pantanosas, tais como: aninga-açu (Monitrichardia linifera), guajiru (Humiria floribunda) e araticum-do-brejo (Annona glabra).

$\mathrm{Na}$ parte mais seca ocorrem algumas arbóreas dispersas, tais como dendê (Elaeis guineenis), embaúba-do-brejo (Cecropia peltata) e ingaí (Inga capitata).

Este ambiente é fundamental para a manutenção do mangue, em virtude do fornecimento de água doce e de nutrientes. Possivelmente sua falta implicaria a destruição dos manguezais.

\section{Mangue}

$\mathrm{Na}$ área de estudo ocorrem duas manchas de manguezais: uma maior, no trecho final do rio Guaju, a cerca de $1 \mathrm{~km}$ (um quilômetro) de sua foz; e outra menor, ao sudoeste da lagoa pré-dunar. Esta última apresenta-se raquítica e pouco diversa. 
Esta formação caracteriza-se por apresentar solo argiloso misturado com matéria orgânica, que favorece o desenvolvimento de vários organismos, como larvas de peixes, moluscos e crustáceos. A vegetação arbórea é dominada por quatro espécies típicas: mangue-sapateiro (Rhizophora mangue), mangue-manso (Laguncularia racemosa), mangue-botão (Conocarpus erectus) e mangue-canoé (Avicennia schaueriana).

Este ambiente apresenta alta densidade de moluscos e crustáceos, que por sua vez são atrativos para outros grupos animais que vão à procura de alimento.

Formações pioneiras

Nestas formações estão incluídas todas as áreas onde houve invasão de espécies pioneiras após a remoção da cobertura vegetal, inclusive clareiras naturais, e especialmente, as pilhas de rejeito em recuperação.

Entre as espécies herbáceas e arbustivas que se instalam, inicialmente tem-se: a jurubeba (Solanum paniculatum), gengibre (Paspalum maritimum) e a mutamba (Guazuma ulmifolia).

Formação antrópica

A formação antrópica da área de estudo é constituída por um plantio de cana-deaçúcar desativado, a sudoeste da área do projeto. Algumas espécies pioneiras começam a se instalar, como a cupiúba (Tapirira guianensis), jurubeba (Solanum paludosum) e carrapicho (Cenchrus echinatus).

\subsection{Fauna : descrição dos grupos faunísticos estudados}

Os principais taxa que foram inventariados no Projeto da Mina Guaju foram os mamíferos, aves, répteis, anfíbios, crustáceos e peixes (DOTE SÁ et al., 1993).

Foram catalogadas no total 202 espécies de animais. A maior quantidade é da classe das aves, com 112 espécies de animais, distribuída em 38 famílias, sendo as mais numerosas as famílias Fringilidae e Thraupidae. 
No grupo dos mamíferos, foram registradas 22 espécies, distribuída em 15 famílias, sendo as famílias Didelphidae e Dasypodidae as mais representadas.

$\mathrm{Na}$ classe dos répteis, foram inventariadas 24 espécies distribuídas em 08 famílias diferentes. A maior quantidade de indivíduos pertence à família Colubridae que é composta de muitos ofídios; todos não venenosos.

Da classe dos peixes, apenas 26 espécies foram catalogadas até o momento. Esta classe é a que possui a maior quantidade de espécies a serem inventariadas. A maioria das espécies observada até o momento é de peixes estuarinos, especialmente da família Mugilidae, à qual pertencem às tainhas.

Os crustáceos mais comuns foram inventariados, sendo identificados 11 espécies, distribuídas em oito famílias. A família mais importante é a Gecarcinidae, com duas espécies com importância econômica: o caranguejo-uçá (Ucides cordatus) e o goiamun (Cardisoma guanhumi).

A classe com menor quantidade de indivíduos, inventariada até o momento, é a dos anfíbios, com apenas sete indivíduos distribuídos em quatro famílias, sendo os leptodactilídeos os mais importantes, pois inclui a única espécie que sofre pressão antrópica, o (Leptodactylus pentadactylus), conhecida como jia ou rã.

Estudos finalizados, referente ao levantamento de insetos, em especial de formigas, não foram registrados. O único trabalho desenvolvido com formigas (ZANZINI et al., 1994) encontra-se publicado parcialmente e não foram encontrados, até o momento, registros da identificação do levantamento realizado por este autor.

\subsubsection{Processo de recuperação de pilhas de rejeito}

A recuperação das pilhas de rejeito tem como premissa uma lavra bem planejada, para conciliar uma boa integração entre as atividades de mineração e recuperação. Os objetivos prioritários do plano de recuperação adotado pela empresa consistem na reconstituição de novas dunas com o relevo mais próximo possível das condições originais, propiciando a formação de uma cobertura vegetal permanente, que permita a fixação das massas arenosas, tendo como proposição a melhoria das condições estéticas da paisagem, além da recuperação do potencial biótico da área (DOTE SÁ et al., 1993). 
A mineração de areia quartzosa litorânea, como é o caso do empreendimento da Mina do Guaju, mostra algumas particularidades. Em toda a área considerada como jazida não existe estéril, sendo todo o corpo dunar lavrado após a retirada da cobertura vegetal e da camada de solo. Toda a cobertura vegetal e o solo orgânico são utilizados no processo de recuperação de áreas degradadas.

Assim, o Programa de Recuperação de dunas litorâneas segue todo um procedimento, que foi desenvolvido inicialmente em 1989, e que vem sendo aprimorado ao longo de todos estes anos, através de estudos e testes realizados juntamente com a implantação das técnicas já aprovadas. Este processo intensivo de pesquisas consiste em catalogar e testar as espécies locais quanto a suas potencialidades de adaptação e colonização nas áreas mineradas. Passou-se a testar fórmulas de adubação, reduzir os fatores limitantes locais, através da instalação de barreiras quebra-ventos. Dessa forma, após treze anos de estudos, pode-se afirmar que, para as condições locais, a Empresa dispõe de uma série de práticas que permitem a sustentabilidade nas áreas recuperadas a curto, médio e longo prazos, conforme descrito a seguir (CUNHA et al., 2001b).

Antes mesmo do início da operação da lavra, dá-se o início das atividades que atualmente são realizadas no processo de recuperação das áreas mineradas. Este processo se inicia com a realização de inventários qualitativos sobre a fauna e a flora da área a ser lavrada. Esta atividade é realizada com a finalidade de subsidiar os trabalhos de revegetação e possibilitar a transferência de espécimes da fauna, que, por ventura, não tenham sido afugentadas para outras áreas, com o ruído das máquinas. Nesta etapa também são coletados espécimes da flora e fauna que sejam de interesse, como troncos ocos e enxames de abelhas, os quais são transferidos para as pilhas de rejeito já revegetadas, de modo a proporcionar melhores condições de adaptação da fauna, acelerando o processo de recuperação (informação pessoal) ${ }^{25}$.

\footnotetext{
${ }^{25}$ Dados fornecidos pelo Setor de Meio Ambiente da Mina do Guaju - Lyondell Chemicals Company, em agosto de 2002.
} 
Após esta primeira etapa, é iniciado o denominado pré-desmatamento manual (Figura 13), o qual se processa com o auxílio de moto-serra para a retirada do material lenhoso. O objetivo desta segunda etapa é facilitar o processo de desmatamento mecânico, dar continuidade ao resgate de espécimes da fauna e da flora para posterior enriquecimento da área em processo de recuperação, além de reduzir o tempo de carregamento e transporte de todo o material lenhoso juntamente com o solo, que serão destinados às pilhas de rejeito.

Para facilitar o desmatamento mecânico (Figura 14), ou seja, o destocamento de raízes e amontoamento do material orgânico - decapeamento da matéria orgânica. Nesta fase, são construídas estradas temporárias, o que facilita o acesso das máquinas tornando todo o processo mais ágil. Para construção destas estradas é utilizado material argiloso com concreções quartzo-ferruginosas (piçarra), provenientes da Formação Barreira. Todo o material amontoado nesta etapa é diretamente transportado até a parte mais alta das pilhas de rejeito a serem recuperadas (Figura 15 e 16).

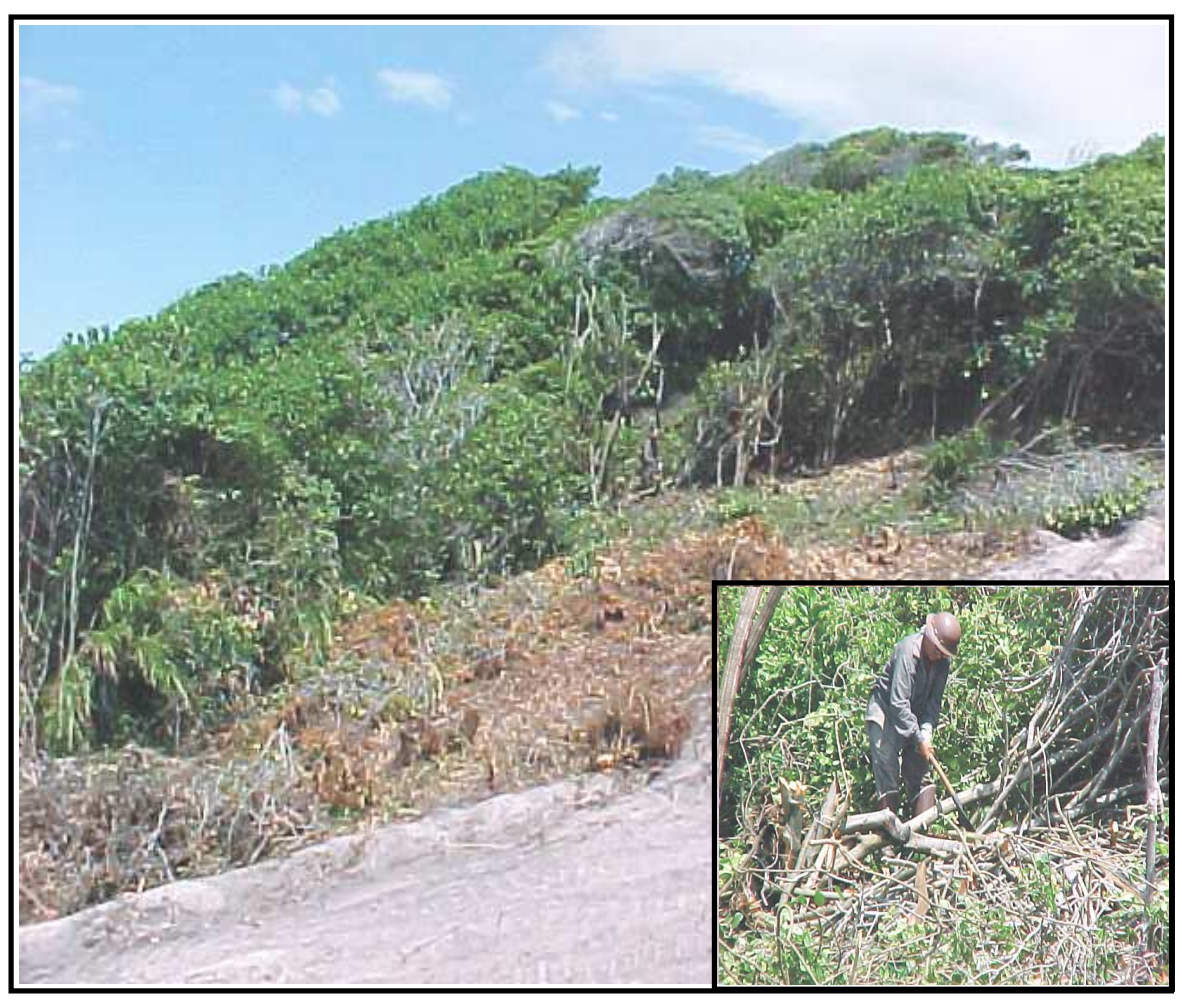

Fonte: informação pessoal ${ }^{26}$

Figura 13 - Pré-desmatamento manual.

${ }^{26}$ Foto fornecida pelo Setor de Meio Ambiente da Mina do Guaju - Lyondell Chemicals Company, em 22 de novembro de 2002. 


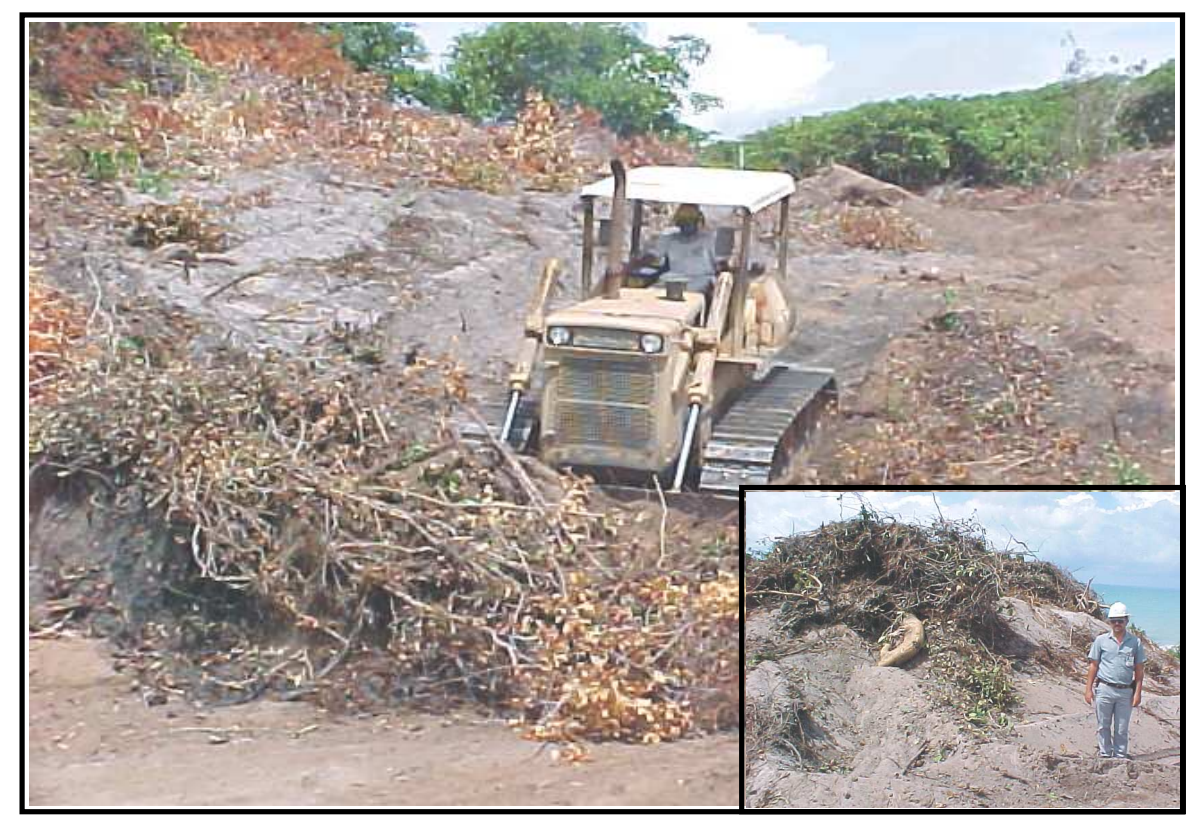

Fonte: informação pessoal ${ }^{27}$

Figura 14 - Desmatamento mecânico - decapeamento da camada orgânica.

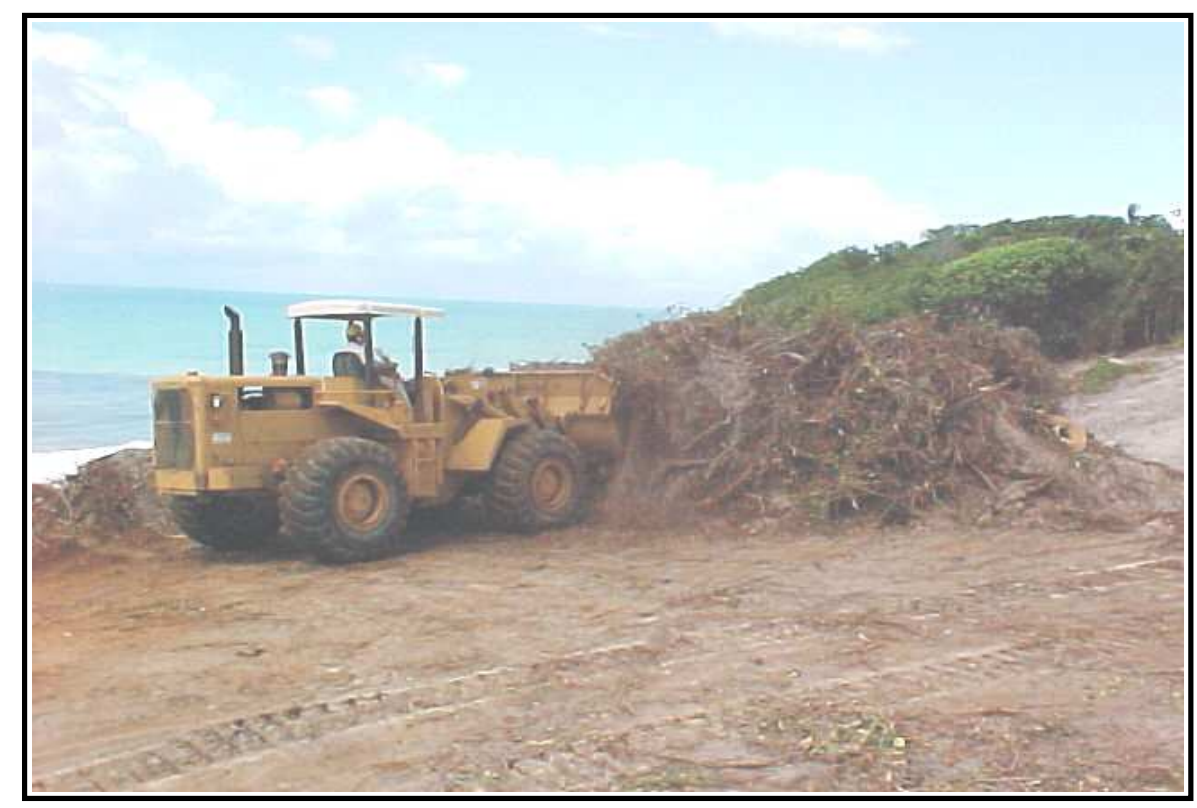

Fonte: informação pessoal ${ }^{28}$

Figura 15 - Início da etapa de transporte da matéria orgânica.

${ }^{27},{ }^{28}$ Fotos fornecidas pelo Setor de Meio Ambiente da Mina do Guaju - Lyondell Chemicals Company, em 22 de novembro de 2002. 
A operação de espalhamento do solo orgânico sobre as pilhas de rejeito é uma operação delicada, porque ocorrem taludes de alta declividade. Nas partes planas, a distribuição é realizada facilmente por um trator de esteiras e, nas partes íngrimes, por dois tratores de esteiras unidos por um cabo de aço. Um dos tratores fica parado no topo da duna, enquanto o outro desce espalhando o solo até a base desta, quando é tracionado pelo primeiro, conseguindo, assim, uma distribuição mais homogênea do material sobre a duna (informação pessoal) ${ }^{29}$.

Após o espalhamento do solo orgânico sobre as pilhas de rejeito, são construídos de dois a três quebra-ventos físicos, elaborados com telas sombrites, distanciados de 6 a 10 metros uns dos outros, conforme a necessidade apresentada na localização da área a ser recuperada. Estes visam bloquear o processo erosivo causado pela ação dos fortes ventos alísios, sendo construídos no sentido perpendicular à ação dos ventos, evitando, assim, a invasão de areia nas áreas de plantio (Figura 17).

Além dos quebra-ventos físicos são introduzidos os quebra-ventos biológicos (Figura 18), para os quais, atualmente, são plantados dois diferentes tipos de vegetação exótica, devido ao rápido crescimento e estrutura que apresenta a espécie. Esta prática é utilizada para aumentar mais a proteção contra a ação do vento e tornar possível um melhor desenvolvimento e sobrevivência das espécies nativas que serão plantadas posteriormente. São plantadas fileiras de "capim-napier" (Penissetum purpureum Schum.) e de Acacia mangium. A principal função do "capim-napier" é proteger as mudas que formarão os quebra-ventos, sendo utilizadas duas linhas, espaçadas um metro uma da outra. Depois, são plantados cinco linhas de Acacia mangium, com espaçamento de $2 \times 2 \mathrm{~m}$ e plantio intercalado. Entre o final de um quebra-vento e o início de outro, há um intervalo de 43 metros, onde é realizada a revegetação com espécies nativas (informação pessoal) ${ }^{30}$.

\footnotetext{
${ }^{29},{ }^{30}$ Dados Fornecidos pelo Setor de Meio Ambiente da Mina do Guaju - Lyondell Chemicals Company, em agosto de 2002.
} 


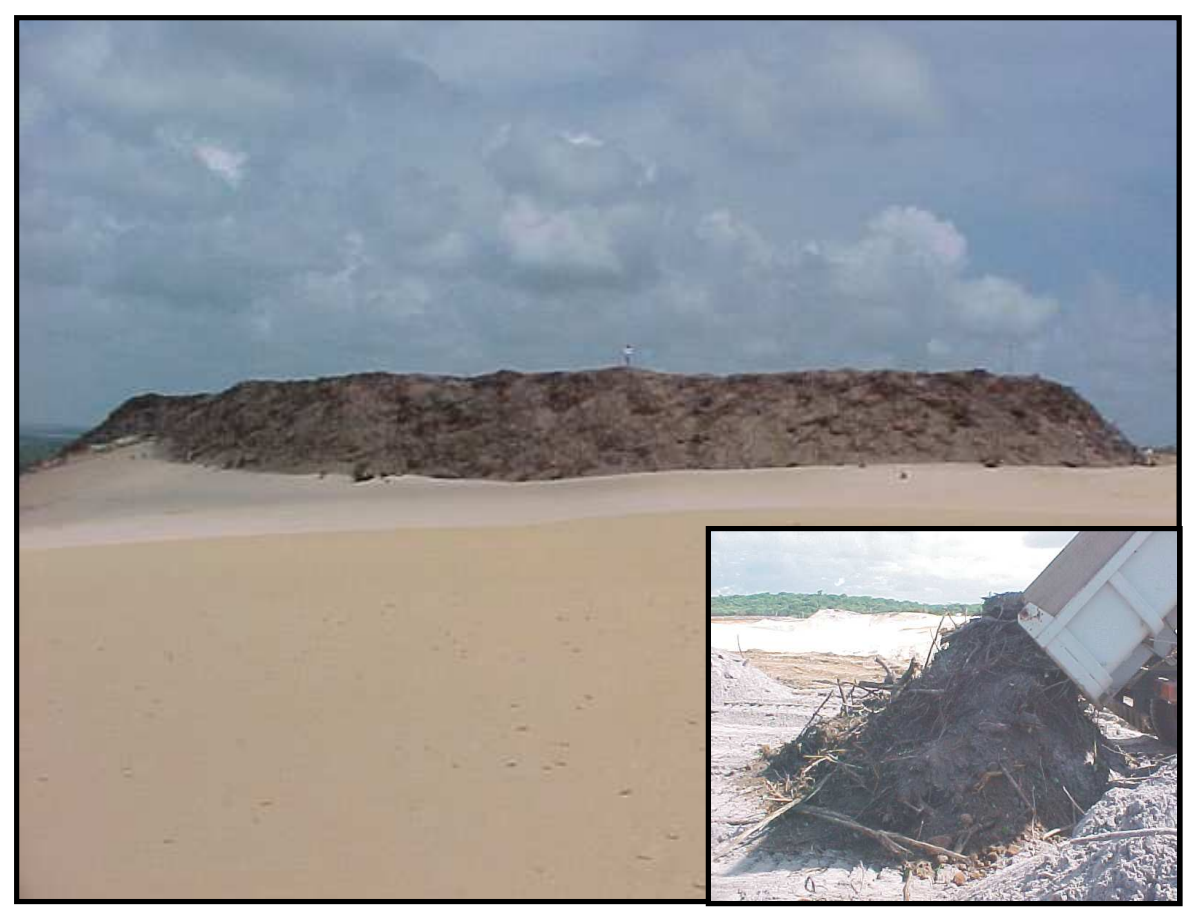

Fonte: informação pessoal ${ }^{31}$

Figura 16 - Descarregamento da matéria orgânica no topo da pilha de rejeito a ser recapeada.

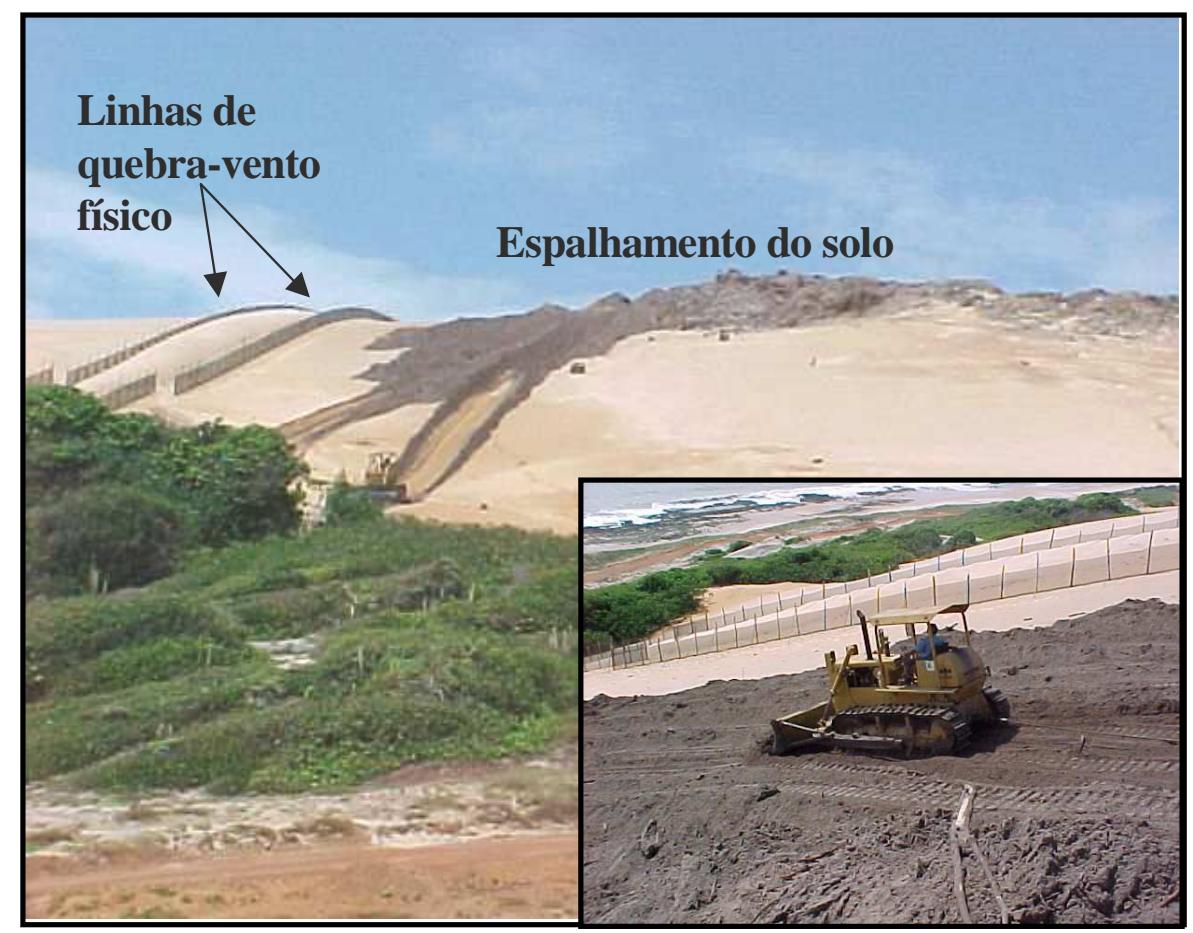

Fonte: informação pessoal $\left.\right|^{32}$

Figura 17 - Espalhamento do solo nas pilhas de rejeito, mostrando detalhe dos quebra-ventos físicos.

${ }^{31}$, ${ }^{32}$ Fotos fornecidas pelo Setor de Meio Ambiente da Mina do Guaju - Lyondell Chemicals Company, em 22 de novembro de 2002. 


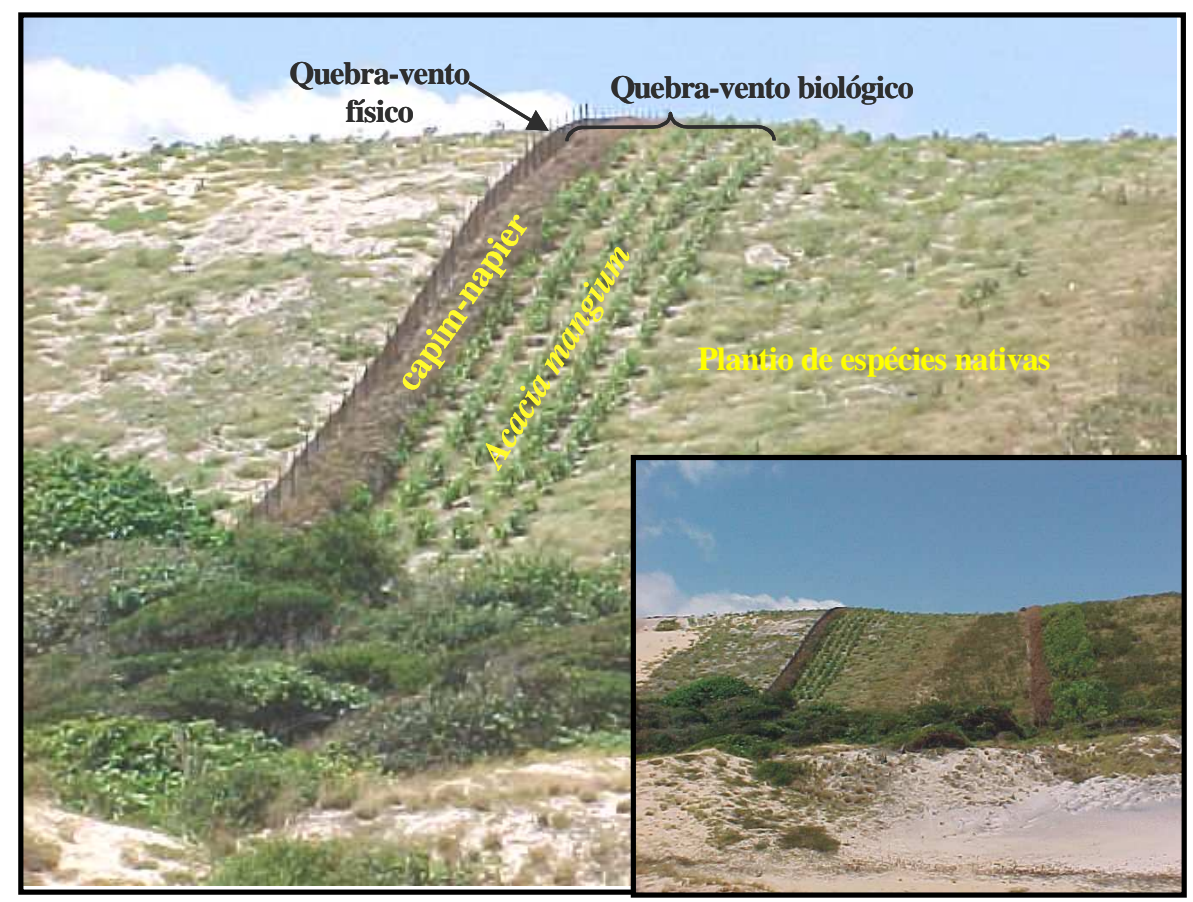

Figura 18 - Disposição de quebra-ventos físicos e biológicos.

Fonte: informação pessoal ${ }^{33}$

Após o plantio das espécies nativas, é necessária a construção de outros quebra-ventos físicos, junto à linha dos quebra-ventos biológicos, aumentando ainda mais a proteção contra os ventos. Estudos vêm sendo realizados com o intuito de substituição das espécies exóticas, atualmente utilizadas, por espécies nativas que possam desempenhar a mesma função de quebra-ventos biológicos, tornando possível, em um futuro próximo, a total erradicação das espécies exóticas utilizadas neste processo de revegetação (informação pessoal) ${ }^{34}$.

Quanto à escolha das espécies nativas a serem plantadas, isto é feito através de testes de sobrevivência. São escolhidas as espécies com melhor desenvolvimento e adaptação às condições locais do plantio, as quais são denominadas como pioneiras, sendo as primeiras a serem introduzidas no plantio.

Desde 1988, o Setor de Meio Ambiente da Mina do Guaju seleciona espécies apropriadas para colonizar as dunas. Inicialmente, foram utilizados propágulos vegetativos de Ipomoea pes-caprae (L.) Sweet (Convolvulaceae), Canavalia brasiliensis Mart. ex. Benth (Leguminosae - Faboidae), Paspalum maritimum Trin. e Cynodon dactylon (L.) Pers. (Poaceae), que apresentavam grande habilidade para

\footnotetext{
${ }^{33}$ Foto fornecida pelo Setor de Meio Ambiente da Mina do Guaju - Lyondell Chemicals Company, em 22 de novembro de 2002.

34 Dados fornecidos pelo Setor de Meio Ambiente da Mina do Guaju - Lyondell Chemicals Company, em 12 de agosto de 2002.
} 
colonizar áreas arenosas praianas. Desde então, muitas outras espécies foram testadas sobre as dunas, principalmente as identificadas na restinga original.

Em 1993, eram utilizadas mais de trinta espécies diferentes nos plantios das dunas. Espécies de ocorrência natural como Anacardium occidentale L., Tapirira guianensis Aubl. (Anacardiaceae), Tabebuia roseo-alba (Ridl.) Sandw. (Bignoniaceae), Tocoyena selloana Schum., Guettarda platypoda DC. (Rubiaceae), Manilkara salzmanii (A. DC.) H. J. Lam. (Sapotaceae), Ziziphus joazeiro Mart. (Rhamnaceae), Hancornia speciosa Gomez (Apocinaceae), Eugenia kunthiana DC., Eugenia uvalha Camb. (Myrtaceae), Cupania revoluta Radlk. (Sapindaceae) e Hymenaea courbaril L. (Leguminosae - Caesalpinioidae), entre outras, tinham suas mudas produzidas no viveiro da empresa e eram plantadas consorciadas, num total de 1.500 plantas por hectare. As espécies herbáceas eram introduzidas a título de aceleração do processo de cobertura do solo. Concomitantemente aos plantios de campo, realizavam-se testes adaptativos com espécies potenciais (informação pessoal) ${ }^{35}$.

A partir de 1994, com uma razoável gama de estudos e resultados, partiu-se para uma nova fase, em que as espécies que tiveram comportamento destacado nesses seis anos de pesquisa permaneceram como a base dos plantios programados. Estas espécies estão fazendo o papel de pioneiras antrópicas, ou seja, espécies que não são tipicamente da floresta primária, mas que cumprem este papel em áreas antropizadas (KAGEYAMA et al., 1994), melhorando as características do sítio para espécies mais exigentes. São elas: Anacardium occidentale L. (Anacardiaceae), Mimosa caesalpiniaefolia Benth., Mimosa sp. (Leguminosae - Mimosoidae) Tabebuia roseo-alba (Ridl.) Sandw. (Bignoniaceae), Tocoyena selloana Schum. (Rubiaceae), Ziziphus joazeiro Mart. (Rhamnaceae) e Guazuma ulmifolia Lam. (Sterculiaceae).

Os plantios atuais incluem desta forma, as espécies vegetais supracitadas e outras que embora tenham um desenvolvimento mais lento, aumentam a diversidade sobre as dunas. No que tange ao procedimento de plantio, este é realizado da mesma forma que nos quebra-ventos. O replantio e as atividades de manutenção também são análogos. O espaçamento utilizado é $2 \times 2 \mathrm{~m}$, totalizando 2.500

${ }^{35}$ Dados fornecidos pelo Setor de Meio Ambiente da Mina do Guaju - Lyondell Chemicals Company, em agosto de 2002. 
mudas/ha. Entretanto, deste total, 460 mudas estão nos quebra-ventos de acácia e outras 90, representam o espaço ocupado pelas linhas de capim. Assim, na revegetação são usadas cerca de 1.950 mudas/ha.

Para o último plantio começado no início do mês de abril de 2002 (início da época de chuva), foram produzidas cerca de 76 mil mudas, com mais de 60 espécies diferentes: sendo que aproximadamente $18 \%$ equivalem às espécies exóticas utilizadas como quebra-ventos, e $82 \%$ equivalem às espécies nativas da região. O elenco de espécies nativas produzidas no viveiro da empresa para a revegetação das pilhas de rejeito, para o ano de 2002, pode ser observado no ANEXO C.

No final de todo o processo de revegetação, alguns acessos são desativados, permanecendo apenas os principais, que passam a ser denominados como estradas permanentes, as quais servirão para facilitar o processo de manutenção destas áreas.

Para que o processo de recuperação seja bem sucedido, é necessário que a revegetação seja acompanhada constantemente. Desta forma, após o primeiro ano de plantio, é realizado o replantio de aproximadamente $25 \%$ do total de mudas plantadas no início, visando repor eventuais perdas de mudas e permitir a manutenção da densidade média de mudas vivas por hectare (informação pessoal) ${ }^{36}$.

Após o plantio, os espécimes presentes são adubados e seu entorno capinado quadrimestralmente, até que atinjam o dobro da altura da vegetação espontânea. Cabe salientar que o solo de mata espalhado como substrato, além de favorecer o desenvolvimento das mudas plantadas, contém um rico banco de sementes, favorecendo o surgimento de diversas outras espécies no local, as quais, de porte arbóreo e arbustivo, também recebem o mesmo tratamento das mudas plantadas (Figura 19). A partir do segundo ano, inicia-se o processo de poda das espécies exóticas, tal procedimento é feito com o corte de galhos que possam estar prejudicando o desenvolvimento das espécies nativas, sendo somente eliminadas quando as espécies nativas atingem cerca de 1,5 metros de altura.

Esta atividade traz grandes benefícios, pois a decomposição da matéria verde podada é incorporada ao solo, o qual passa a adquirir um aporte extra de nutrientes,

\footnotetext{
${ }^{36}$ Dados fornecidos pelo Setor de Meio Ambiente da Mina do Guaju - Lyondell Chemicals Company,
} em agosto de 2002. 
permitindo um melhor desenvolvimento das espécies nativas. Também é iniciado o processo de adensamento de várias espécies nativas, as quais, depois de introduzidas, recebem os devidos cuidados para que seu desenvolvimento seja bem sucedido (Figura 20). Além disto, também são realizadas atividades de adubação, controle local de formigas e manutenção de acesso, sempre que necessário; sem contar a reintrodução da fauna acompanhada de um monitoramento específico. Todos esses processos contribuem para um excelente desenvolvimento do processo de recuperação, proporcionando uma maior biodiversidade para o novo ecossistema formado.

O acompanhamento das áreas de revegetação é feito ao longo de 10 anos, tempo, julgado pela empresa, suficiente para capacitar a auto-sustentabilidade do novo ecossistema formado, conforme pode ser observado na primeira duna que foi revegetada (Figura 21 ).

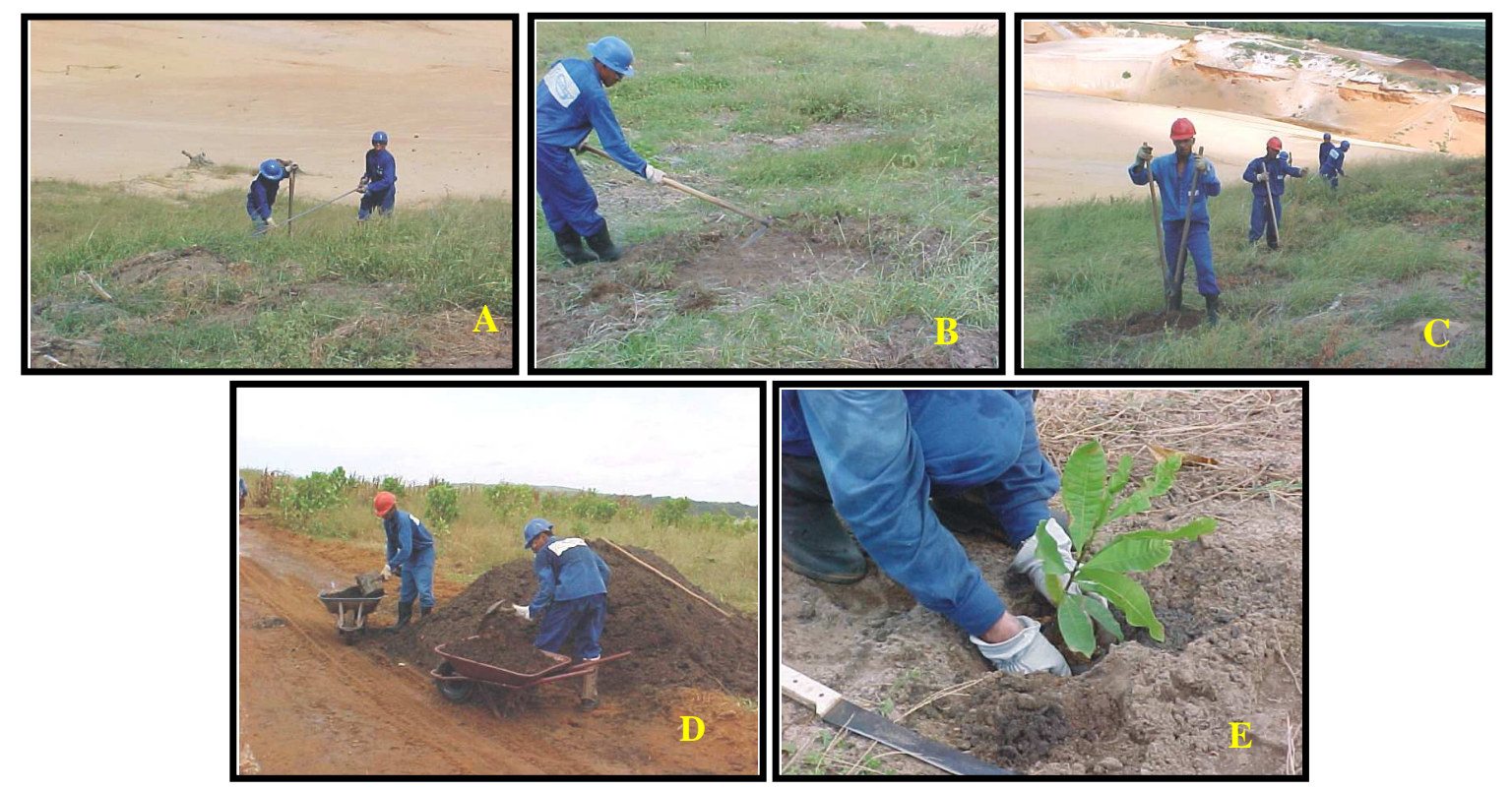

Fonte: informação pessoal ${ }^{37}$

Figura 19 - Processo de revegetação: A - Medição das covas para plantio; B Capina no local da cova; C - Preparação das covas; D - Composto para adubação nas covas; E - Plantio das mudas.

${ }^{37}$ Fotos fornecidas pelo Setor de Meio Ambiente da Mina do Guaju - Lyondell Chemicals Company, em 22 de novembro de 2002. 


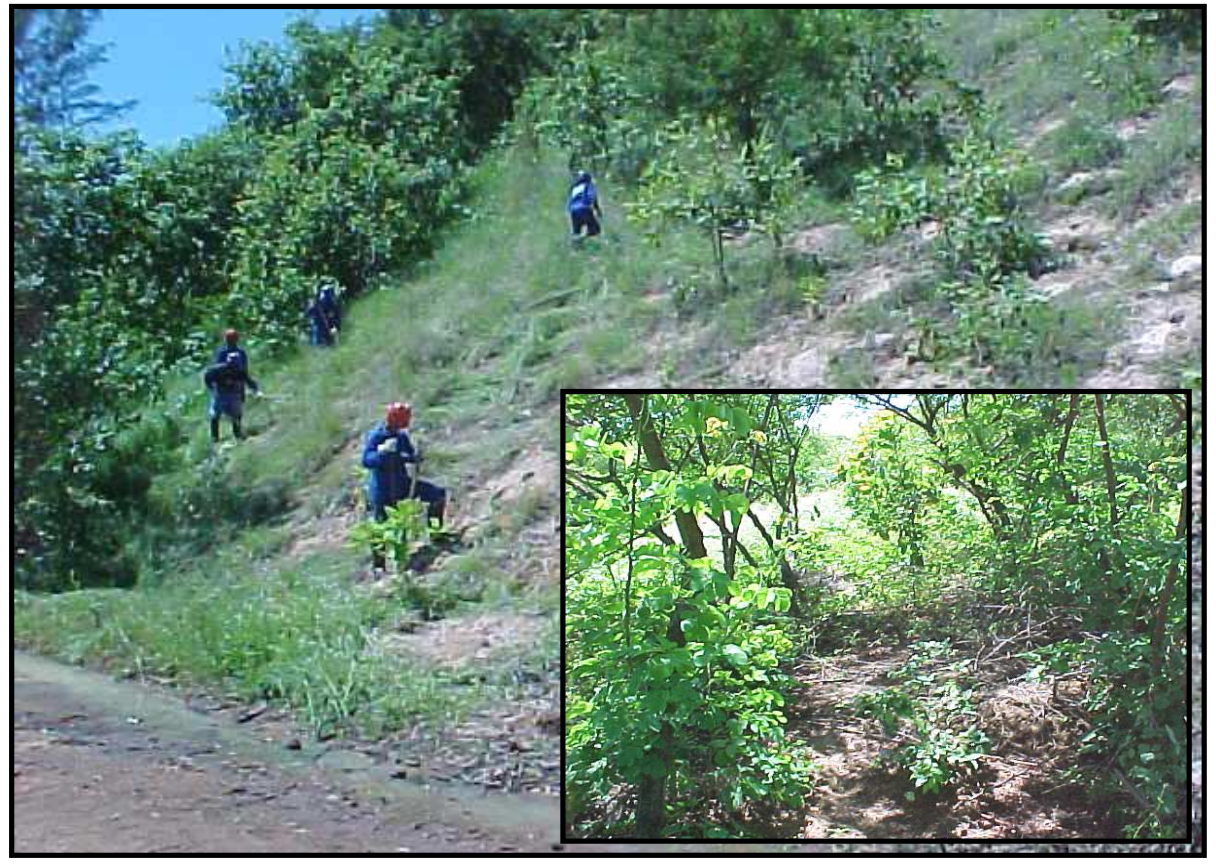

Fonte: informação pessoal ${ }^{38}$

Figura 20 - Processo de adensamento de espécies em dunas já inicialmente revegetadas.

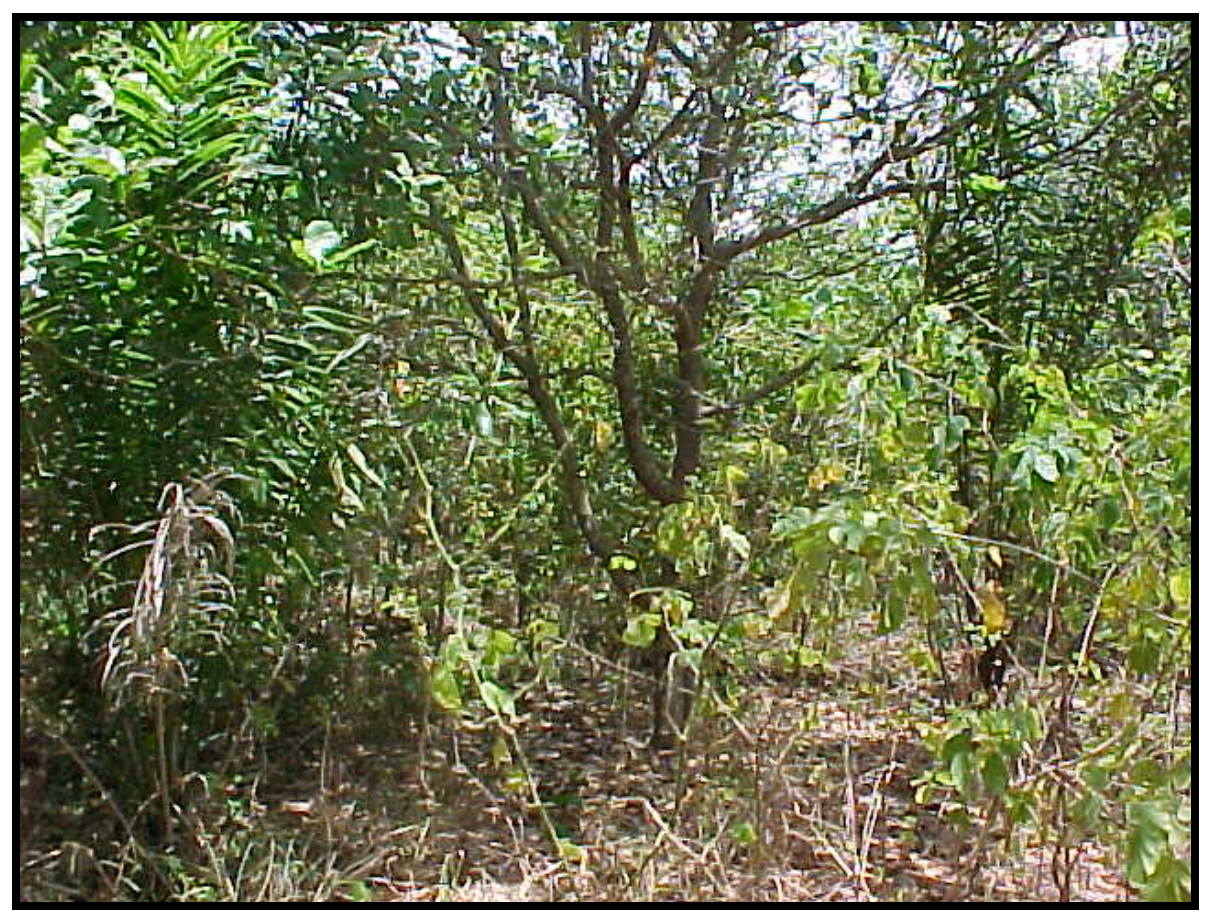

Fonte: informação pessoal ${ }^{39}$.

Figura 21 - Duna recuperada com 13 anos.

38 , 39 Fotos fornecidas pelo Setor de Meio Ambiente da Mina do Guaju - Lyondell Chemicals Company, em 22 de novembro de 2002. 


\subsubsection{Outras atividades que subsidiam o processo de recuperação}

Como parte do programa de recuperação, foi estabelecido, no sítio da Paraíba, um viveiro de mudas (Figura 22), um criadouro conservacionista (Figura 23) e uma área de quarentena para readaptação de pássaros e aves silvestres (Figura 24), os quais auxiliam no processo de recuperação da flora e fauna das pilhas de rejeito da Mina do Guaju. A Mina do Guaju é a única mineração a manter parceria com o governo brasileiro para retornar animais a seu habitat natural. $O$ Instituto Brasileiro do Meio Ambiente e dos Recursos Naturais Renováveis (IBAMA), órgão nacional de regulamentação ambiental, reconheceu o programa desenvolvido no sítio da Paraíba, como um dos melhores programas de recuperação das áreas de mineração no Brasil (informação pessoal) ${ }^{40}$.

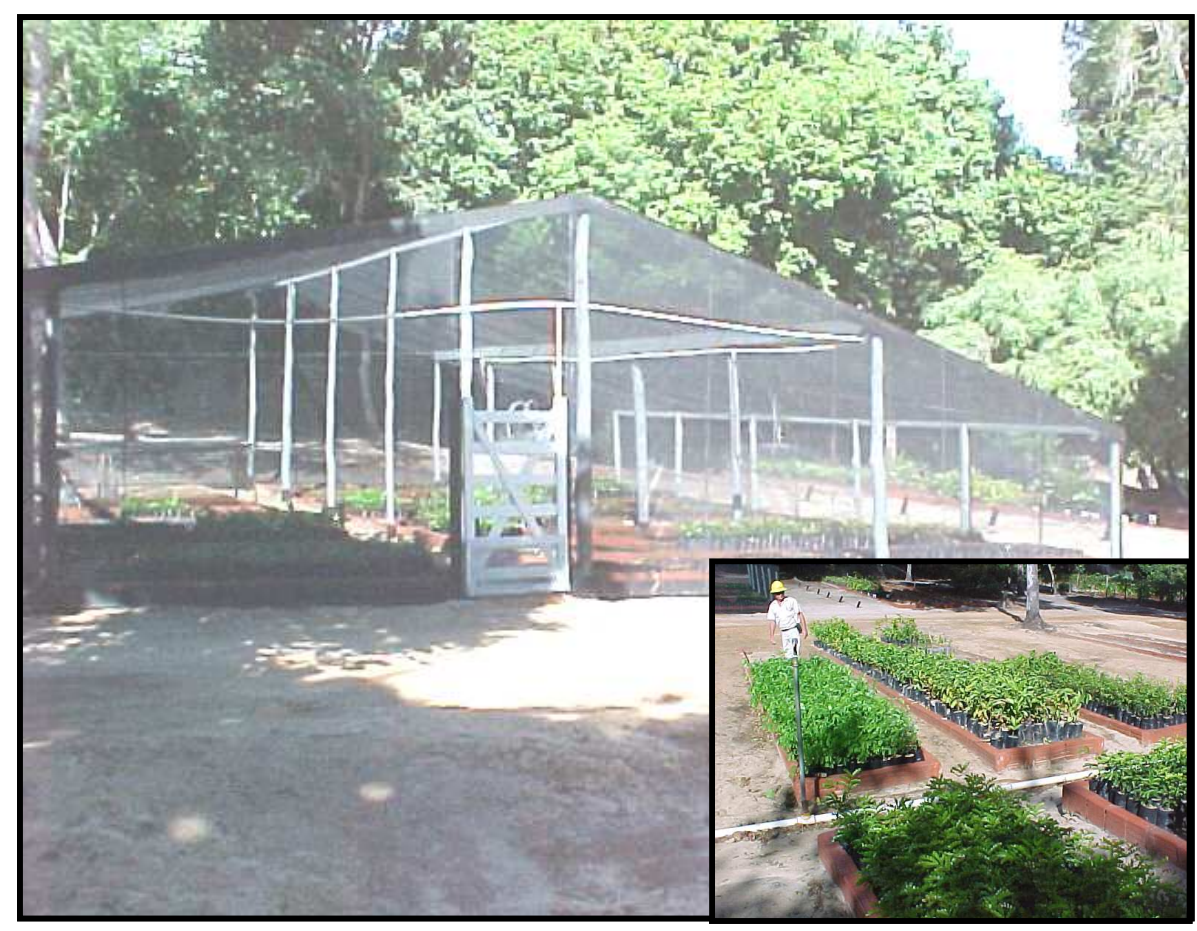

Fonte: informação pessoal ${ }^{41}$

Figura 22 - Casa de vegetação, viveiro de mudas.

\footnotetext{
40 Comunicação verbal fornecida pelo geólogo Renato Castro - Chefe do Setor de Meio Ambiente da Mina do Guaju - Paraíba, em 11 de setembro de 2002.

41 Fotos fornecidas pelo Setor de Meio Ambiente da Mina do Guaju - Lyondell Chemicals Company, em 22 de novembro de 2002.
} 


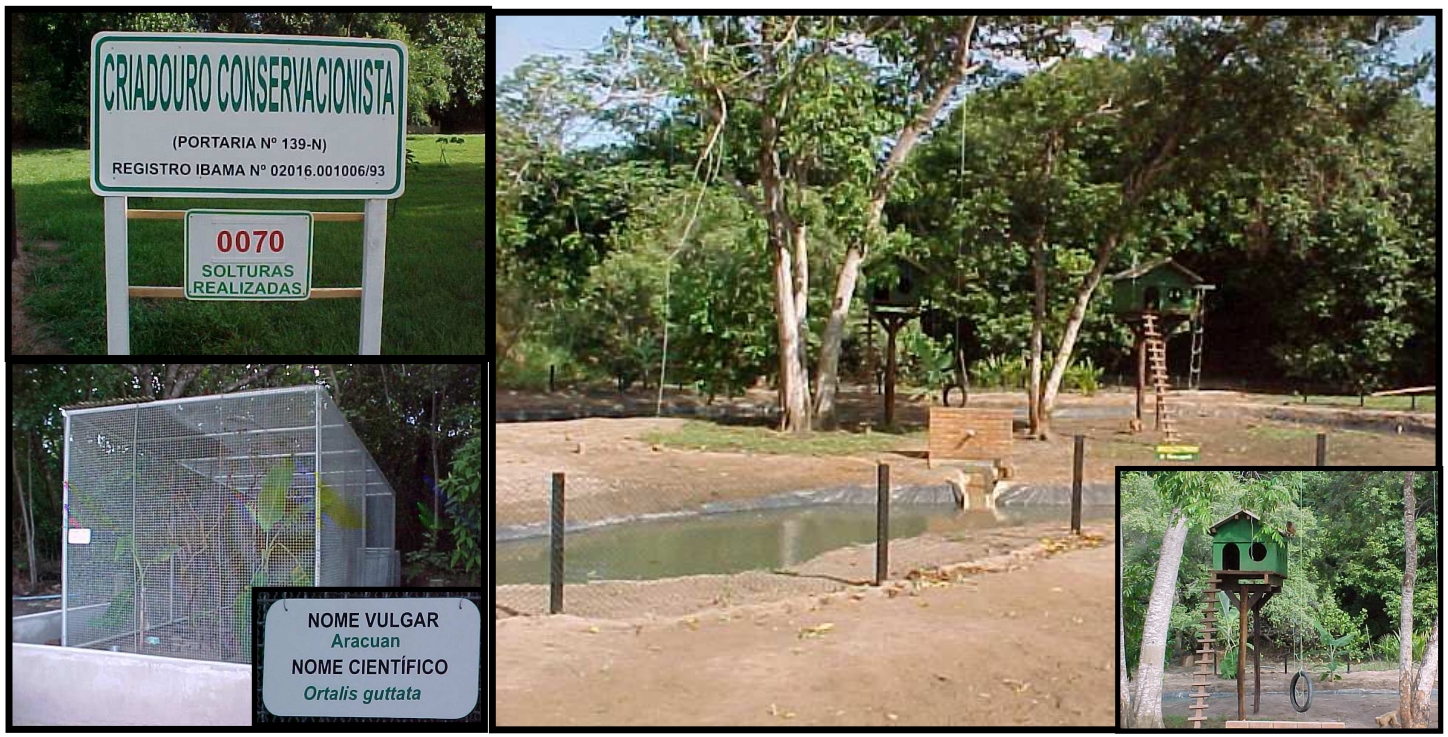

Figura 23 - Criadouro conservacionista.

Fonte: informação pessoal ${ }^{42}$

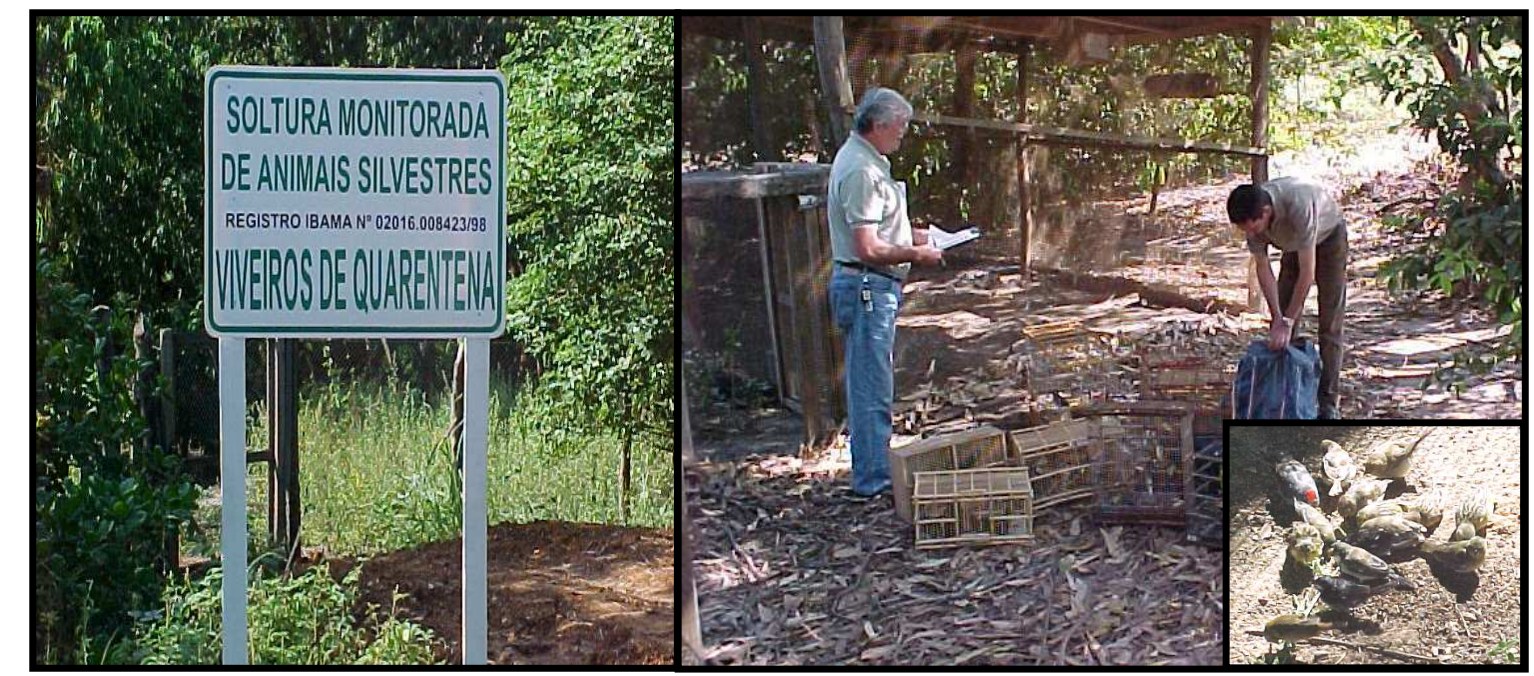

Figura 24 - Viveiro de quarentena.

Fonte: informação pessoal ${ }^{43}$

${ }^{42}$, ${ }^{43}$ Fotos fornecidas pelo Setor de Meio Ambiente da Mina do Guaju - Lyondell Chemicals Company, em 22 de novembro de 2002. 


\subsection{APLICAÇÃO METODOLÓGICA}

Para a aplicação da metodologia, proposta no Capítulo 3 foram necessárias três etapas distintas: "Etapa de Escritório", "Etapa de Campo", e "Etapa de Laboratório". A primeira etapa baseou-se no levantamento de todos os trabalhos desenvolvidos no setor de meio ambiente da área de estudo, incluindo dados da empresa, mapas e descrições ambientais bióticas e abióticas locais.

Após a análise de todos os dados, partiu-se para a segunda etapa - "Etapa de Campo", em que, a princípio, foram acompanhadas todas as atividades desenvolvidas no setor de meio ambiente, principalmente as relacionadas com as técnicas de recuperação das pilhas de rejeito, possibilitando o conhecimento, entendimento e análise do ambiente de estudo e, após a preparação do material da "Etapa de Laboratório", foi efetivada a coleta de formigas.

A última etapa consistiu na preparação de todo o material necessário para possibilitar o início da parte prática desse estudo, ou seja, o início das coletas de formigas, preparação do material para identificação e análises.

\subsubsection{Escolha das áreas de coletas}

Para este estudo foram definidas seis áreas de coletas (ANEXO D). Para a escolha de cada área, seguiram-se os parâmetros indicados no Capítulo 3.

1. Tempo de revegetação: foram escolhidas áreas com idades não muito próximas que pudessem representar fases distintas do processo de revegetação. A primeira área com estágio avançado de revegetação, a segunda área com estágio recente de revegetação, e mais duas áreas intermediárias. Além de mais duas áreas distintas, com vegetação nativa e sem influência direta das atividades de lavra foram escolhidas como referência, ou seja, áreas controle. 
2. Tratamento do substrato: todas as áreas escolhidas receberam tratamento com solo orgânico, uma vez que ficou constatada a reintrodução da camada de solo nas pilhas de rejeito como o melhor tratamento a ser aplicado no substrato (TEIXEIRA; ROSADO; OLIVEIRA FILHO, 1987).

3. Tipo de plantio: todas as áreas escolhidas receberam técnicas de revegetação com um elenco misto de espécies nativas, com exceção de uma área teste, onde se pretendeu avaliar o tratamento distinto, descrito a seguir, no item 4.2.2, ao caracterizar as áreas de coletas.

4. Tamanho anual das áreas revegetadas: o plantio do elenco de espécies vegetais selecionadas para o processo de revegetação é realizado anualmente, durante a época de chuva. A área de recuperação é composta de várias porções de plantios com idades, tamanhos e localização diferentes. Assim, procurou-se escolher áreas de tamanhos, mais homogêneos.

5. Disposição e formato: levou-se em consideração o efeito de borda e a proximidade das áreas.

6. A escolha da área controle: optou-se pela escolha de duas áreas nativas, dentro dos limites do decreto de lavra, que pudessem representar, de forma semelhante, o ambiente existente antes da atividade de lavra.

Após a análise detalhada do mapa da área de recuperação, foram selecionadas as áreas de coleta, das quais podemos observar localização, disposição e formato, na Figura 25. 


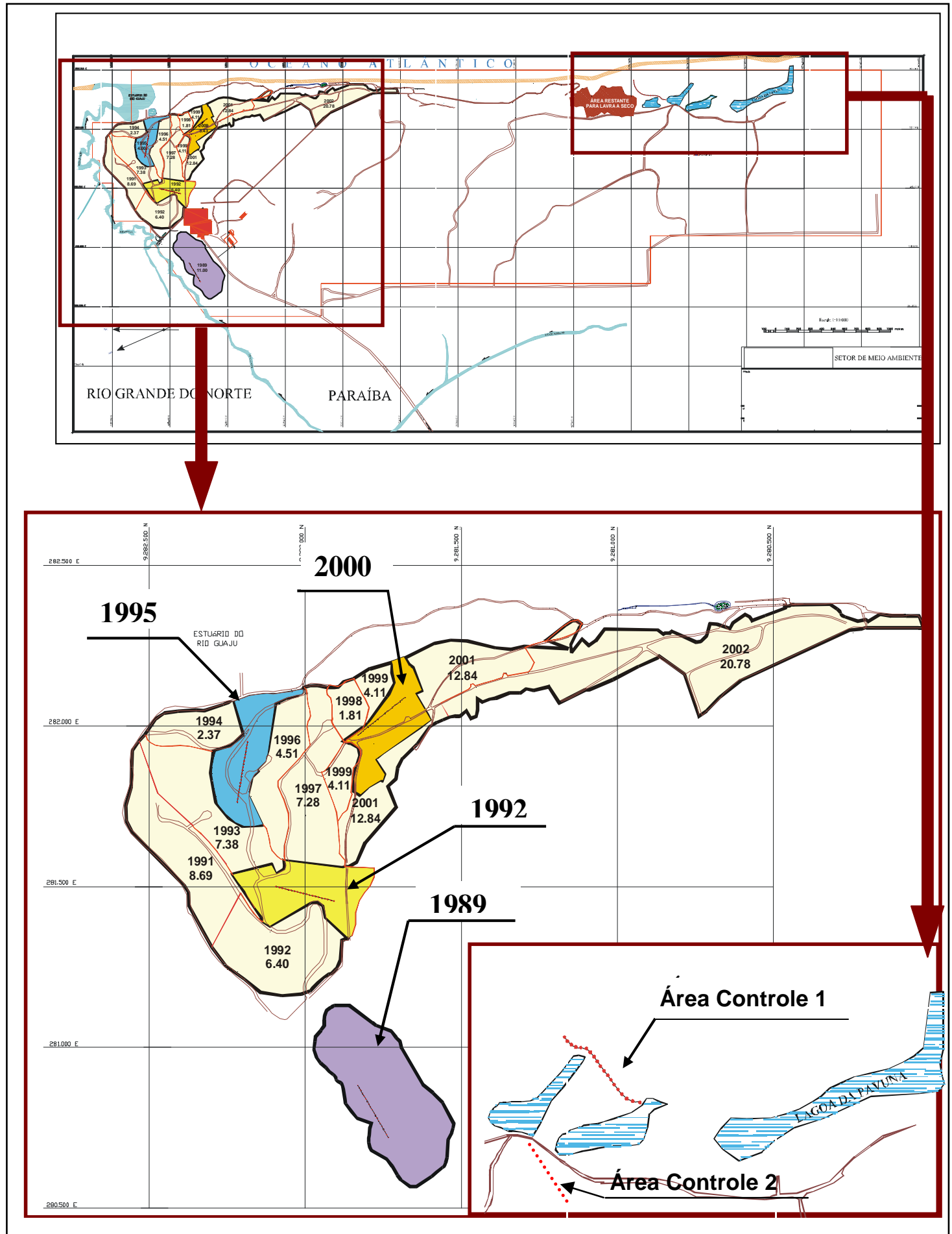

Fonte: informação pessoal ${ }^{44}$

Figura 25 - Localização das áreas de coletas de formigas.

44 Mapa fornecido pelo Setor de Meio Ambiente da Mina do Guaju - Lyondell Chemicals Company, modificado pela autora, em 29 de janeiro de 2003. 


\subsubsection{Caracterização de cada área de coleta}

Todas as áreas de coleta foram caracterizadas com a ajuda do biólogo Claudeci Santana da Silva, assistente de meio ambiente, responsável pela maioria das atividades de recuperação desenvolvidas no Setor de Meio Ambiente da Mina do Guaju, o qual possui profundo conhecimento da composição biótica das áreas nativas pertencentes ao decreto de lavra da Mina do Guaju (informação pessoal) ${ }^{45}$.

\subsubsection{1 Áreas Controle (AC1 e AC2)}

As áreas selecionadas para controle possuem vegetação semelhante às áreas que estão sendo utilizadas no processo de lavra pela mineração. São áreas com ocorrência de dunas de idade recente, formadas após regressão marinha nos últimos 5000 anos, algumas dunas não possuem ainda vegetação fixadora completamente estabelecida, sendo chamadas de dunas semifixas. As áreas são similares a maioria das áreas em processo de recuperação, principalmente quanto à exposição aos fatores estressantes, ou seja, ventos, altitude e condições edáficas (Figura 26).

${ }^{45}$ Comunicação verbal do geólogo Renato Castro - Chefe do Setor de Meio Ambiente da Mina do Guaju - Lyondell Chemicals Company, em 05 de maio de 2002. 


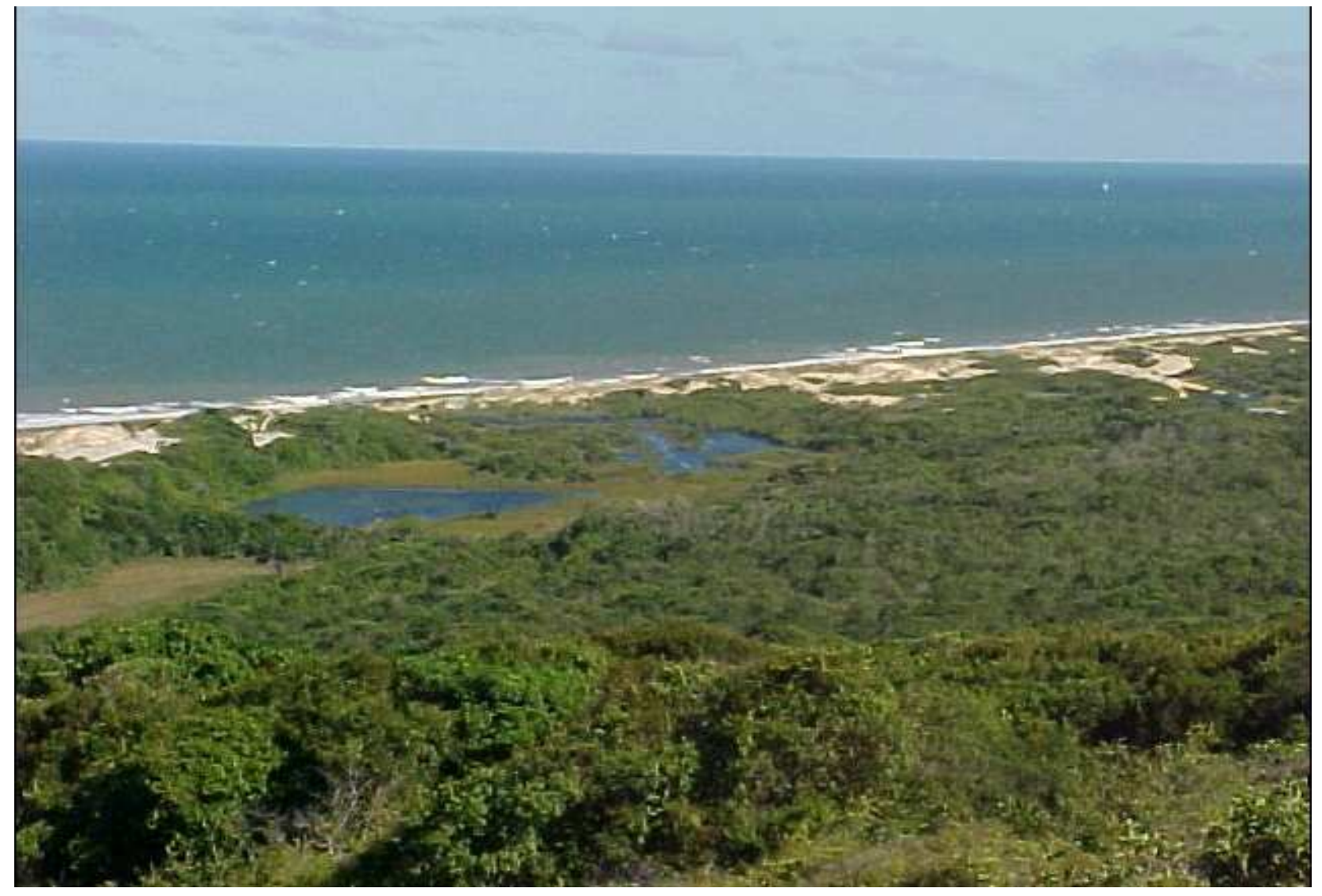

Fonte: informação pessoal ${ }^{46}$

Figura 26 - Vista aérea das lagoas - local das áreas controle.

\subsubsection{1 Área Controle 1 (AC1)}

A vegetação predominante é de porte arbustivo, onde o domínio é de espécies da família Myrtaceae, especialmente os gêneros Eugenia e Psidium. Também estão bem representados os gêneros Coccoloba e Esenbeckia.

Ainda há na área ocorrências isoladas de bosques de espécies arbóreas, localizadas nos vales protegidos da ação dos ventos marinhos, principais limitantes ao desenvolvimento da vegetação. As principais espécies arbóreas são: As sapotáceas Manilkara salzmannii e Pouteria marginata e as Fabaceas do gênero Andira.

46 Foto fornecida pelo Setor de Meio Ambiente da Mina do Guaju - PB - Lyondell Chemicals Company, em 14 de março de 2003. 
No fundo destes vales ocorrem pequenos corpos d'água, chamadas de lagoas freáticas. Estas surgem onde a topografia do terreno intercepta o lençol freático, sendo, portanto, muito sujeito ao regime de chuvas. As principais espécies ciliares são samambaias, juncáceas e ainda o Chrysobalanus icaco, arbusto muito comum em ambientes úmidos. Podemos citar ainda a grande ocorrência do cajueiro - Anacardium ocidentalle, nas dunas semifixas, como uma das espécies que contribuem para fixação dessas dunas.

A seguir, na Tabela 4.4 e na Figura 27, é possível observar uma tabela contendo a listagem de espécies vegetais encontradas ao longo do transceto onde as armadilhas foram dispostas e fotos da Área Controle 1, respectivamente.

Tabela 4.4 - Listagem de espécies vegetais encontradas ao longo do transecto das armadilhas, na Área Controle 1.

\begin{tabular}{clllc}
\hline N. & \multicolumn{1}{c}{ Espécie } & \multicolumn{1}{c}{ Nome comum } & Ocorrência & Hábito \\
\hline 1 & Abrus precatorius & olho-de-pombo & frequente & tr \\
2 & Anacardium ocidentalle & Cajueiro-nativo & abundante & ab/av \\
3 & Anthurium harisii & Antúrio-da-praia & ocasional & aa/tr \\
4 & Arikuryroba schisophylla & Aricuri & ocasional & pl \\
5 & Borreria verticillata & vassourinha-de-botão & ocasional & er \\
6 & Byrsonima gardneriana & Murici-da-praia & frequente & ab \\
7 & Britoa triflora & Guabiraba & ocasional & av \\
8 & Chrysobalanus icaco & Guajiru & frequente & ab \\
9 & Cecropia obtusa & Embaúba-branca & raro & ab \\
10 & Cyperus lanceolatus & tiriricão ? & frequente & er \\
11 & Cereus pernambucensis & Cactus grande & ocasional & Sc \\
12 & Pilosocereus hapalacanthus & cactos rasteiro & ocasional & $\mathrm{sc}$ \\
13 & Calycorectes sellowianum & azeitona-do-mato & frequente & av \\
14 & Cestrum laevigatum & cestrum & raro & ab \\
15 & Chaetocarpus myrsinites & pau-mondé & ocasional & av \\
16 & Coccoloba vellosiana & cavaçu-rasteiro & frequente & ab \\
17 & Coccoloba & Fura-bucho & ocasional & ab \\
18 & Coccoloba cordifolia & Garajao & frequente & pr \\
19 & Diospyros inconstans & café-da-praia & ocasional & ab \\
20 & Esembeckia sp. & pau-de-cutia & abundante & ab \\
21 & Eugenia flava & jaboticaba-brava & frequente & av \\
& & & & Continua \\
& & & &
\end{tabular}


Tabela 4.4 - Listagem de espécies vegetais encontradas ao longo do transecto das armadilhas, na Área Controle 1.

\begin{tabular}{|c|c|c|c|c|}
\hline N. & Espécie & Nome comum & Ocorrência & Hábito \\
\hline 22 & Eugenia sp. & maria preta & ocasional & av \\
\hline 23 & Eugenia ovalifolia & Pau-branco-praia & freqüente & $a b$ \\
\hline 24 & Eugenia insípida & Murta-branca & freqüente & av \\
\hline 25 & Erythroxylum sp. & Coca-falsa & freqüente & $s b$ \\
\hline 26 & Erythroxylum andrei & Cumixar-preto & freqüente & $a b$ \\
\hline 27 & Eugenia aff. crenata & Cambuim-do-taboleiro & abundante & $a b / a v$ \\
\hline 28 & Ficus gomeleira & Gameleira & raro & av \\
\hline 29 & Guetarda platypoda & Angélica & freqüente & $a b$ \\
\hline 30 & Guapira pernambucensis & Cipó-da-praia & abundante & $\mathrm{pr}$ \\
\hline 31 & Hippeastrum stylosum & Lírio & ocasional & sc \\
\hline 32 & Ingá capitata & Ingá-tripa & ocasional & av \\
\hline 33 & Stigmaphyllam paralias & jitirana-de-batata & freqüente & er \\
\hline 34 & Manihot sp. & Maniçoba & ocasional & $a b$ \\
\hline 35 & Manilkara salzmannii & Massaranduba & abundante & av \\
\hline 36 & Maytenus distichophylla & Bom-nome & frequente & $a b / a v$ \\
\hline 37 & Maytenus erythroxylum & Cuião-de-bode & ocasional & $a b$ \\
\hline 38 & Norantea sp. & Rabo-de-arara & freqüente & $\mathrm{pr}$ \\
\hline 39 & Ormosia arbórea & Mucunã & frequente & $\operatorname{tr}$ \\
\hline 40 & Ouratea cearensis & bati-da-mata & freqüente & ab/av \\
\hline 41 & Psidium sp. & Batinga & abundante & $a b / a v$ \\
\hline 42 & Protium heptaphyllum & Amescla & frequente & av \\
\hline 43 & Phylodendron imbe & Imbé & ocasional & $\operatorname{tr}$ \\
\hline 44 & Pithecelobim pedicelare & Jurema-branca & freqüente & $a b / a v$ \\
\hline 45 & Pradosia glyciphloca & Mamãozinho & ocasional & av \\
\hline 46 & Pouteria margionata & Goiti & freqüente & av \\
\hline 47 & Polygala hebeclada & roxinha & ocasional & er \\
\hline 48 & Rapanea guianensis & pororoca & ocasional & $a b / a v$ \\
\hline 49 & Smilax brasiliensis & Japecanga & ocasional & $\operatorname{tr}$ \\
\hline 50 & Stylosanthes guianensis & meladinho & freqüente & er \\
\hline 51 & Solanum paludosusm & Jurubeba-amarela & frequente & $a b$ \\
\hline 52 & Simaba ferrugínea & Cajarana-da-praia & freqüente & av \\
\hline 53 & Tocoyena selloana & Jenipapo-bravo & freqüente & $a b$ \\
\hline 54 & Thalia geniculata & Arararuta-brava & freqüente & er \\
\hline 55 & Tetracera breyniana & Cipó-de-fogo & abundante & $\operatorname{tr}$ \\
\hline 56 & Trema micrantha & tamanqueiro & raro & $a b$ \\
\hline
\end{tabular}


Tabela 4.4 - Listagem de espécies vegetais encontradas ao longo do transecto das armadilhas, na Área Controle 1.

\begin{tabular}{llllc}
\hline N. & \multicolumn{1}{c}{ Espécie } & \multicolumn{1}{c}{ Nome comum } & \multicolumn{1}{c}{ Ocorrência } & Hábito \\
\hline 57 & Tabebeuia roseo-alba & Ipê-branco & freqüente & av \\
58 & Dalechampia scandens & Tamiarana & freqüente & $\mathrm{tr}$ \\
59 & Ximenia americana & Ameixa-brava & freqüente & $\mathrm{ab}$ \\
60 & Zollernia ilicifolia & Pau-santo & frequente & $\mathrm{av}$ \\
61 & Cayaponia angustiloba & Abobrinha do mato & ocasional & $\mathrm{tr}$ \\
62 & Pithecelobium sp. & barbatimão branco & raro & $\mathrm{ab}$ \\
63 & Pêra ferruginea & sete-cascos & ocasional & av \\
64 & Andira sp. & angelim-da-mata & freqüente & av \\
65 & Nephralepsis sp. & samambaia & ocasional & er \\
66 & Eugenia sp. & araçá-de-porco & ocasional & av \\
\hline
\end{tabular}

Legenda: Hábitos: $\mathrm{av}=$ árvore; $\mathrm{ab}=$ arbusto; $\mathrm{sb}=$ subarbusto; er = erva; $\mathrm{tr}=$ trepadeira; $\mathrm{pr}=$ procubente; $\mathrm{sc}=$ suculenta; $\mathrm{pl}=$ palmeira; $\mathrm{aa}=$ aracea .

47 Dados coletados pelo biólogo Claudeci Santana da Silva - Assistente de Meio Ambiente da Mina do Guaju - Lyondell Chemicals Company, em 04 de outubro de 2002. 


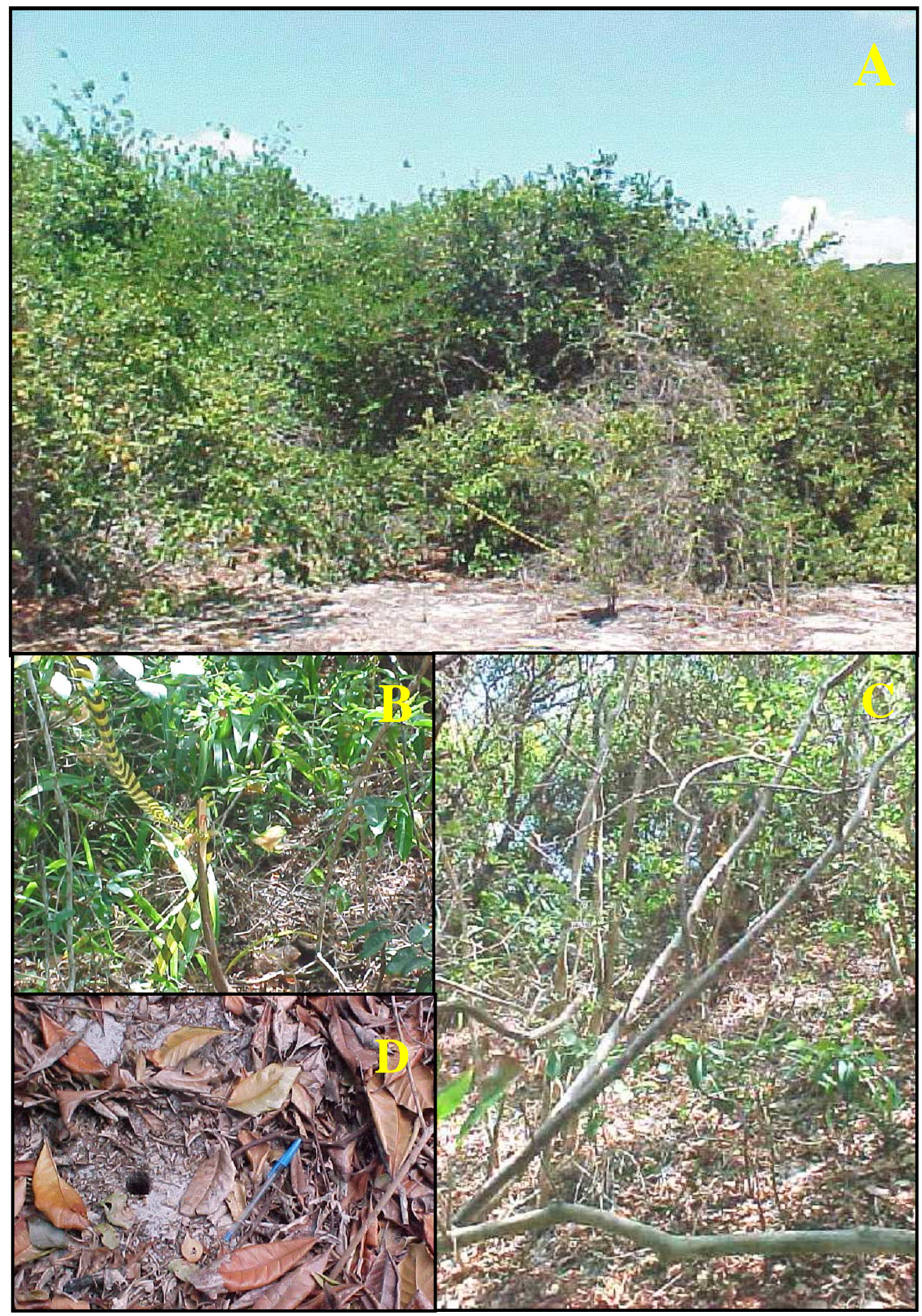

Fonte: informação pessoal ${ }^{48}$

Figura 27 - Fotos de detalhes da Área Controle 1 (AC1): A e C - porte da vegetação; $B$ - armadilha sinalizada; $D$ - presença de serapilheira.

${ }^{48}$ Fotos do arquivo pessoal da autora, em 23 de setembro de 2002. 


\subsubsection{2 Área Controle 2 (AC2)}

A área possui vegetação de porte predominantemente arbóreo, especialmente nas áreas mais baixas e úmidas, onde os principais fatores estressantes da região (ventos fortes e escassez hídrica) são praticamente nulos, devido à existência de outras dunas situadas à leste e pelo fato da baixa altitude facilitar o acesso ao lençol freático. Nestas áreas as árvores chegam a atingir até 12 metros de altura, especialmente as espécies clímax do ambiente como a massaranduba (Manilkara salzmanni), o angelim (Andira nitida) a sete-cascas ( Pera ferruginea).

Em outros locais menos protegidos, a vegetação possui porte arbustivo, devido à ação adversa principalmente dos fortes ventos alísios que sopram com muita intensidade durante a maior parte do ano. As espécies são basicamente as mesmas, porém com diferenças no porte e formação da copa. As espécies mais comuns são: o cajueiro (Anacardium occidentale), fura-bucho (Coccoloba sp.), murici (Byrsonima gardneriana) a palmeira Aricuri (Aricuriroba schysophyla) e também várias espécies da família Myrtaceae, especialmente o gênero Eugenia sp. No estrato herbáceo ocorrem além das plântulas das espécies de ocorrência na área, o Antúrio (Anthuryum affine), a açucena (Hippeastrum stylosum), a bromélia-rasteira (Cryptanthus sp.) e a grama-da-mata (Paspalum sp).

As epífitas como o Imbé (Phylodendron imbe) e a orquídea aromática (Epidendrum cf. fragans) ocorrem com freqüência em virtude da elevada umidade do ar devido à proximidade das lagoas. Também ocorre especialmente nas áreas arbustivas, muitas lianas, como o cipó-de-fogo (Tetracera breyniana) e a raminha (Sesbania sp.). Nas áreas mais abertas, como beira de estradas, podemos encontrar cacatáceas (Cereus pernambucensis) o capim fura-capa (Bromus sp.).

A seguir, na Tabela 4.5 e na Figura 28, é possível observar uma tabela contendo a listagem de espécies vegetais encontradas ao longo do transceto onde as armadilhas foram dispostas e fotos da Área Controle 2, respectivamente. 
Tabela 4.5 - Listagem de espécies vegetais encontradas ao longo do transecto das armadilhas, na Área Controle 2.

\begin{tabular}{|c|c|c|c|c|}
\hline N. & Espécie & Nome comum & Ocorrência & Hábito \\
\hline 1 & Hippeastrum stylosum & Açucena & ocasional & SC \\
\hline 2 & Anacardium occidentalle & Cajueiro & abundante & ar \\
\hline 3 & Xylopia nitida & Camaçari & comum & ar \\
\hline 4 & Anthurium affine & Antúrio & abundante & aa \\
\hline 5 & Aricuryroba schysophyla & Aricuri & comum & $\mathrm{pl}$ \\
\hline 6 & Tabebuia roseo-alba & Peroba & comum & ar \\
\hline 7 & Cryptanthus sp. & Bromélia-rasteira & abundante & br \\
\hline 8 & Protium heptaphyllum & Amescla & comum & ar \\
\hline 9 & Cereus pernanbucensis & Cacto-grande & ocasional & sc \\
\hline 10 & Zollernia ilicifolia & Pau-santo & ocasional & ar \\
\hline 11 & Maytenus erythroxylum & Cuião-de-bode & comum & $a b$ \\
\hline 12 & Maytenus distichophylla & Bom-nome & ocasional & ar \\
\hline 13 & Chrysobalanus icaco & Guajiru & freqüente & $a b$ \\
\hline 14 & Clusia burchelli & Orelha-de-burro & raro & ar \\
\hline 15 & Tetracera breyniana & Cipó-de-fogo & abundante & $\operatorname{tr}$ \\
\hline 16 & Chaetocarpus myrsinites & Pau-mondé & comum & ar \\
\hline 17 & Pera ferruginea & Sete-cascas & freqüente & ar \\
\hline 18 & Erythroxilum sp. & Coca-falsa & comum & $s b$ \\
\hline 19 & Erythroxylum andrei & Cumixar-preto & ocasional & ar \\
\hline 20 & Andira nitida & Angelin-da-mata & freqüente & ar \\
\hline 21 & Ormosia arborea & Mucunã & comum & $\operatorname{tr}$ \\
\hline 22 & Ocotea sp. & Louro-branco & ocasional & ar \\
\hline 23 & Norantea sp. & Rabo-de-arara & ocasional & $\mathrm{pr}$ \\
\hline 24 & Byrsonima gardneriana & Murici-da-praia & comum & ar \\
\hline 25 & Pithecelobium pedicellare & Jaguarana & ocasional & $a b$ \\
\hline 26 & Abarema sp & Barbatimão-branco & ocasional & $a b$ \\
\hline 27 & Calycorectes sellowianum & Azeitona-do-mato & comum & ar \\
\hline 28 & Eugenia uniflora & Batinga & abundante & ar \\
\hline 29 & Eugenia insipida & Murta-branca & freqüente & ar \\
\hline 30 & Eugênia sp. & Pau-mulato & abundante & ar \\
\hline 31 & Eugenia sp. & Maria-preta & abundante & ar \\
\hline 32 & Britoa triflora & Guabiraba & abundante & ar \\
\hline 33 & Eugenia aff.crenata & Cambuim & freqüente & ar \\
\hline 34 & Calyptranthes lucida & Purpuna & freqüente & ar \\
\hline 35 & Rapanea guianensis & Pororoca & comum & $a b$ \\
\hline 36 & Guapira pernambucensis & Cipó-da-praia & ocasional & $\mathrm{pr}$ \\
\hline 37 & Ximenia americana & Ameixa & ocasional & $a b$ \\
\hline
\end{tabular}


Tabela 4.5 - Listagem de espécies vegetais encontradas ao longo do transecto das armadilhas, na Área Controle 2.

\begin{tabular}{lllcc}
\hline N. & \multicolumn{1}{c}{ Espécie } & \multicolumn{1}{c}{ Nome comum } & Ocorrência & Hábito \\
\hline 38 & Ouratea cearensis & Bati-da-mata & raro & ar \\
39 & Epidendrum cf. fragans & Orquídea-aromática & freqüente & sc \\
40 & Bromus sp. & Capim-fura-capa & ocasional & er \\
41 & Paspalum sp. & Grama-da-mata & freqüente & er \\
42 & Coccoloba vellosiana & Cavaçu-rasteiro & comum & ab \\
43 & Coccoloba cordifolia & Garajao & abundante & pr \\
44 & Coccoloba sp. & Fura-bucho & comum & ab \\
45 & Faramea sp. & Canela-de-veado & ocasional & ab \\
46 & Guettarda platypoda & Angélica & comum & ab \\
47 & Manilkara salzmannii & Massaranduba & abundante & ar \\
48 & Simaba ferruginea & Cajarana & comum & ar \\
49 & Allophylus puberulus & Cumixar-branco & ocasional & ar \\
50 & Sesbania sp. & Raminha & ocasional & tr \\
\hline
\end{tabular}

Conclusão. Fonte: informação pessoal ${ }^{49}$

Legenda: Hábitos: $\mathrm{av}=$ árvore; $\mathrm{ab}=$ arbusto; $\mathrm{sb}=$ subarbusto; $\mathrm{er}=\mathrm{erva}$; $\operatorname{tr}=$ trepadeira; $\mathrm{pr}=$ procubente; $\mathrm{sc}=$ suculenta; $\mathrm{pl}=$ palmeira; $\mathrm{aa}=$ aracea .

${ }^{49}$ Dados coletados pelo biólogo Claudeci Santana da Silva - Assistente de Meio Ambiente da Mina do Guaju - Lyondell Chemicals Company, em 25 de fevereiro de 2007. 


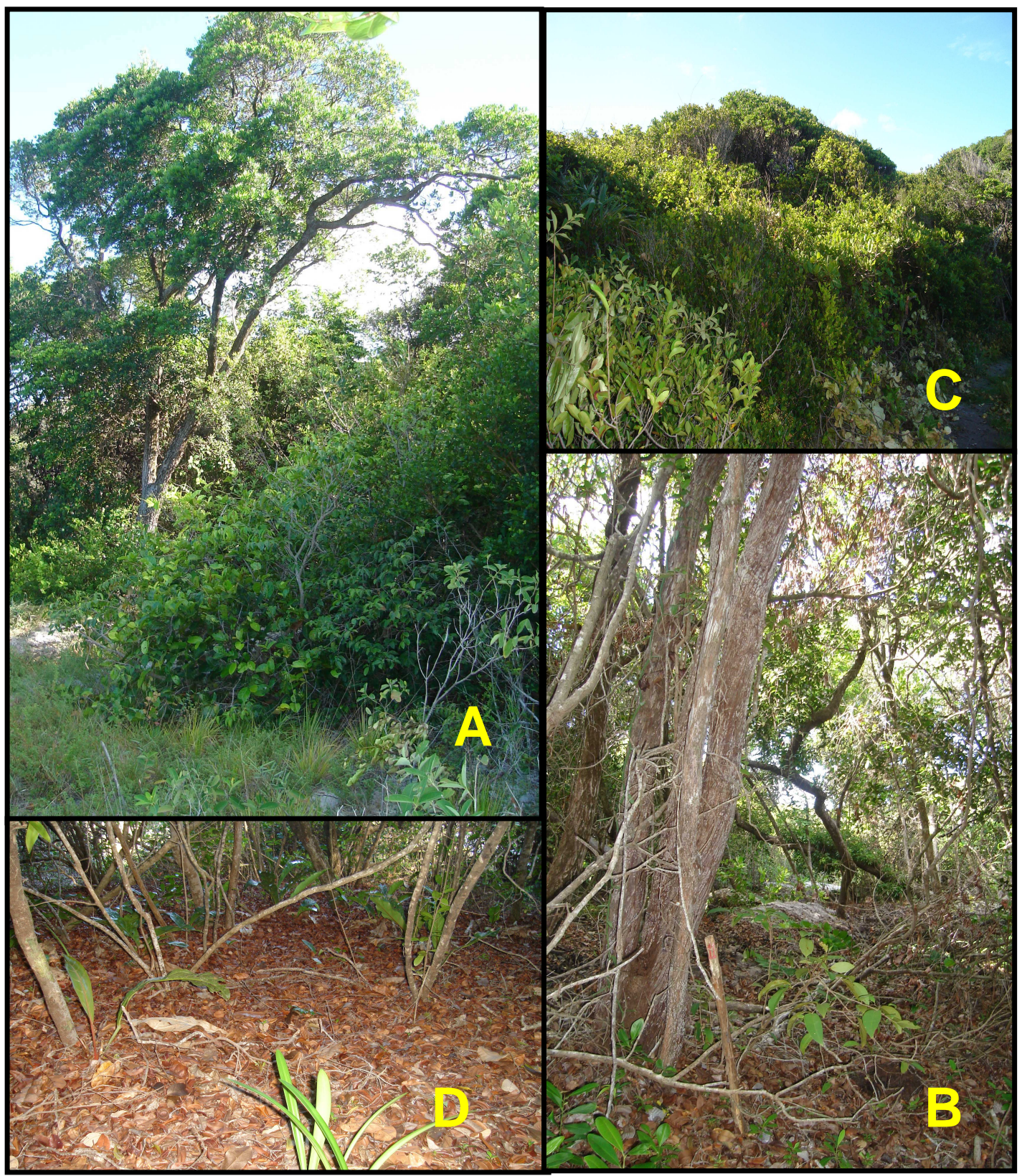

Fonte: informação pessoal ${ }^{50}$

Figura 28 - Fotos de detalhes da Área Controle 2 (AC2): A e C - porte da vegetação; $B$ - armadilha sinalizada; $D$ - presença de serapilheira.

${ }^{50}$ Fotos fornecidas pelo Setor de Meio Ambiente da Mina do Guaju - Lyondell Chemicals Company, em 04 de abril de 2007. 


\subsection{3 Áreas em diferentes etapas de recuperação}

\subsubsection{Plantio 1989 (A89)}

Nesta área o espalhamento do solo, primeira etapa do processo de recuperação, foi executado a partir de meados de 1988, o plantio de mudas foi iniciado no ano seguinte. A área possui vegetação predominantemente arbustiva, sendo que algumas espécies já apresentam porte arbóreo, atingindo de 8 a 12 metros de altura.

As espécies arbóreas predominantes são as Anacardiáceas cajueiro Anacardium ocidentalle e cupiúba - Tapirira guianensis, e ainda, ipê-branco Tabebuia róseo-alba, pau-brasil - Caesalpinia echinata, jitai - Apuleia leiocarpa, juazeiro - Ziziphus joazeiro, mirindiba - Buchenavia capitata, pau-ferroChamaecrista bahiae, etc.. Estas e outras espécies já estão produzindo frutos e contribuindo para o surgimento de muitas plantas a partir das sementes dispersas. No estrato herbáceo, podemos destacar a grande quantidade de orquídea-de-solo Occeoclades maculata, espécie que surge espontaneamente após algumas melhorias nas características do solo, as demais plantas herbáceas ocorrem esparsamente, sendo mais concentradas nas bordas e em locais mais ensolarados.

A seguir, na Tabela 4.6 e na Figura 29, é possível observar uma tabela contendo a listagem de espécies vegetais encontradas ao longo do transceto onde as armadilhas foram dispostas e fotos da área de plantio de 1989, respectivamente. 
Tabela 4.6 - Listagem de espécies vegetais encontradas ao longo do transecto das armadilhas, na área de plantio do ano de 1989.

\begin{tabular}{|c|c|c|c|c|}
\hline $\mathbf{N}$. & Espécie & Nome comum & Ocorrência & Hábito \\
\hline 1 & Abrus precatorius & olho-de-pombo & freqüente & $\operatorname{tr}$ \\
\hline 2 & Anacardium ocidentalle & Cajueiro & abundante & av \\
\hline 3 & Anthurium affine & Antúrio & raro & aa \\
\hline 4 & Apuleia leiocarpa & Jitaí & freqüente & av \\
\hline 5 & Byrsonima gardneriana & murici-da-praia & freqüente & $a b$ \\
\hline 6 & Borreria verticillata & vassourinha-de-botão & ocasional & er \\
\hline 7 & Britoa triflora & Guabiraba & freqüente & av \\
\hline 8 & Caesalpinia echinata & pau-brasil & freqüente & av \\
\hline 9 & Capaifera cearensis & Copaíba & raro & av \\
\hline 10 & Cyperus lanceolatus & Tiriricão & abundante & er \\
\hline 11 & Chamaecrista bahiae & pau-ferro & freqüente & av \\
\hline 12 & Cnidoscolus urens & Urtiga & abundante & er \\
\hline 13 & Cupania revoluta & Cabatã & ocasional & *av \\
\hline 14 & Curatella americana & cajueiro-bravo & raro & $a b$ \\
\hline 15 & Dalechampia scandens & Tamiarana & ocasional & $\operatorname{tr}$ \\
\hline 16 & Elaeis guineensis & dendezeiro & ocasional & $\mathrm{pl}$ \\
\hline 17 & Eugenia brasiliensis & ubaia-folha-grande & ocasional & av \\
\hline 18 & Eugenia insipida & murta-branca & ocasional & av \\
\hline 19 & Eugenia pitanga & pitangueira & raro & $a b$ \\
\hline 20 & Eugenia uniflora & Batinga & freqüente & *av \\
\hline 21 & Ficus gomelleira & Gameleira & raro & av \\
\hline 22 & Guapira noxia & joão-mole & freqüente & av \\
\hline 23 & Guapira pernambucensis & cipó-da-praia & freqüente & $\mathrm{pr}$ \\
\hline 24 & Guazuma ulmifolia & Mutamba & freqüente & $a b$ \\
\hline 25 & Guettarda platypoda & Angélica & freqüente & $a b$ \\
\hline 26 & Ingá thibaudiana & ingá-tatu & ocasional & av \\
\hline 27 & Hymenaea courbaril & Jabotá & freqüente & av \\
\hline 28 & Maytenus distichophylla & bom-nome & ocasional & $a b$ \\
\hline 29 & Manilkara salzmannii & maçaranduba & frequente & av \\
\hline 30 & Paspalum maritimum & capim-gengibre & abundante & er \\
\hline 31 & Passiflora sp.2 & Maracujá-mochila & ocasional & $\operatorname{tr}$ \\
\hline 32 & Philodendron imbe & Imbé & raro & $\mathrm{aa} / \mathrm{tr}$ \\
\hline
\end{tabular}


Tabela 4.6 - Listagem de espécies vegetais encontradas ao longo do transecto das armadilhas, na área de plantio do ano de 1989.

\begin{tabular}{|c|c|c|c|c|}
\hline N. & Espécie & Nome comum & Ocorrência & Hábito \\
\hline 33 & Pouteria marginata & Goiti & ocasional & av \\
\hline 34 & Protium heptaphyllum & Amescla & freqüente & av \\
\hline 35 & Senna sp. 1 & sena-bagaço & freqüente & $a b$ \\
\hline 36 & Senna sp. 2 & Fedegoso-da-mata & freqüente & $a b$ \\
\hline 37 & Setaria vulpiseta & capim-rabo-de-raposa & ocasional & er \\
\hline 38 & Sizigium jambolana & azeitona-oliveira & ocasional & *av \\
\hline 39 & Solanum paludosusm & jurubeba-amarela & abundante & $a b$ \\
\hline 40 & Tabebuia roseo-alba & Peroba & abundante & av \\
\hline 41 & Tapirira guianensis & Cupiúba & abundante & av \\
\hline 42 & Tetracera breyniana & cipó-de-fogo & freqüente & $\operatorname{tr}$ \\
\hline 43 & Tocoyena selloana & jenipapo-bravo & freqüente & $a b$ \\
\hline 44 & Trema micrantha & tamanqueiro & frequente & $a b$ \\
\hline 45 & Turnera ulmifolia & Albina & freqüente & er \\
\hline 46 & Ziziphus joazeiro & Juazeiro & freqüente & av \\
\hline 47 & Zollernia ilicifolia & pau-santo & ocasional & av \\
\hline 48 & Enterolobium contorsiliqum & Tamboril & freqüente & av \\
\hline 49 & Buchenavia capitata & Imbiribiba & freqüente & av \\
\hline 50 & Wulfia stenoglossa & cambará-açú & ocasional & $\mathrm{sb}$ \\
\hline 51 & Occeoclades maculata & orquídea-de-solo & abundante & er \\
\hline 52 & Erythroxilum andrei & cumixar-preto & freqüente & $a b$ \\
\hline 53 & Sida sp. 1 & Malvisco & ocasional & sb \\
\hline 54 & Sida sp. 2 & Chanana & ocasional & er \\
\hline 55 & Merremia glabla & jetirana-de-batata & ocasional & $\operatorname{tr}$ \\
\hline 56 & Commelina nudiflora & erva- de-santa-luzia & ocasional & er \\
\hline 57 & Thalia geniculata & araruta-brava & ocasional & er \\
\hline 58 & Espécie não identificada & orquídea & ocasional & $\operatorname{tr}$ \\
\hline
\end{tabular}

Conclusão. Fonte: informação pessoa ${ }^{51}$

Legenda: Hábitos: $a v$ = árvore; $a b=$ arbusto; $s b=$ subarbusto; er = erva; $\operatorname{tr}=$ trepadeira; $\mathrm{pr}=$ procubente; $\mathrm{pl}=$ palmeira; $\mathrm{aa}=$ arácea. ${ }^{*}$ as espécies arbóreas citadas comportam-se na área como arbustos devido ao curto tempo do plantio.

${ }^{51}$ Dados coletados pelo biólogo Claudeci Santana da Silva - Assistente de Meio Ambiente da Mina do Guaju - Lyondell Chemicals Company, em 04 de outubro de 2002. 


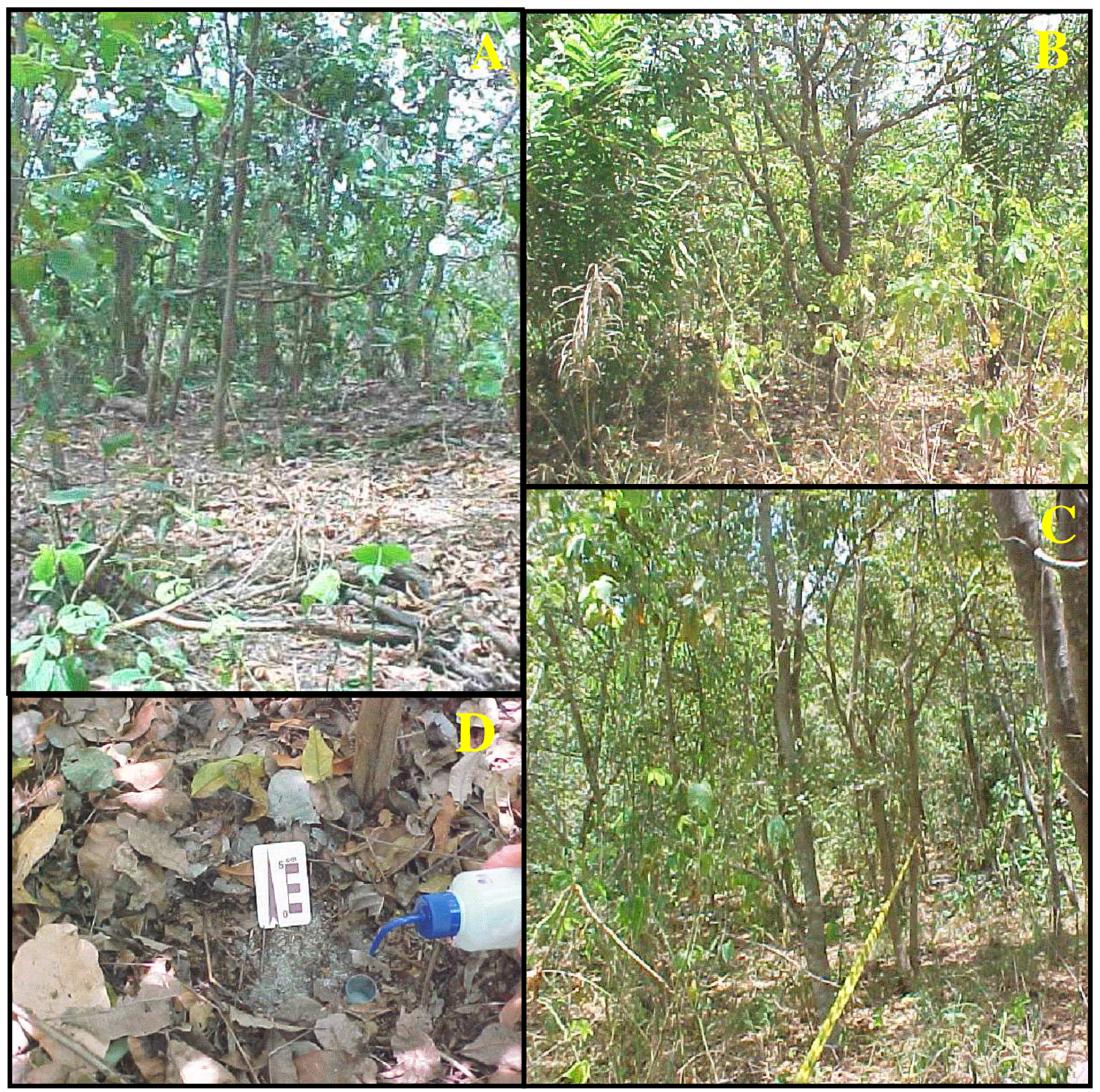

Fonte: informação pessoal ${ }^{52}$.

Figura 29 - Fotos de detalhes da Área de plantio do ano de 1989 (A89): A, B e C porte da vegetação; $\mathrm{D}$ - presença de serapilheira.

52 Fotos da coleção particular da autora, 25 de setembro de 2002. 
Nesta área o espalhamento do solo ocorreu em 1991/1992, o plantio de mudas foi executado em 1992. A vegetação predominante é arbustiva, o porte dos arbustos fica abaixo de 10 metros, as espécies mais desenvolvidas são o cajueiro, ingá-tripa, jenipapo-bravo, murici-da-praia, angélica, estas espécies frutíferas, constituem a fonte de alimento disponível para a fauna. Em alguns locais, onde a vegetação arbustiva é esparsa, o solo está coberto por vegetação herbácea entre os arbustos, onde o domínio é de Rubiáceas, Poáceas, e Asteráceas.

A seguir, na Tabela 4.7 e na Figura 30, é possível observar uma tabela contendo a listagem de espécies vegetais encontradas ao longo do transceto onde as armadilhas foram dispostas e fotos da área de plantio do ano de 1992, respectivamente.

Tabela 4.7 - Listagem de espécies vegetais encontradas ao longo do transecto das armadilhas, na área de plantio do ano de 1992.

\begin{tabular}{clllc}
\hline N. & \multicolumn{1}{c}{ Espécie } & \multicolumn{1}{c}{ Nome comum } & Ocorrência & Hábito \\
\hline 1 & Anacardium occidentale & Cajueiro & abundante & $\mathrm{ab}$ \\
2 & Byrsonima gardneriana & murici-da-praia & freqüente & $\mathrm{ab}$ \\
3 & Britoa triflora & Guabiraba & ocasional & *av \\
4 & Borreria verticillata & vassourinha-de-botão & abundante & $\mathrm{er}$ \\
5 & Bowdichia virgilioides & sucupira -preta & ocasional & *av \\
6 & Calyptranthes lucida & Purpuna & ocasional & $\mathrm{ab}$ \\
7 & Canavalia rosea & fava-de-boi-miúda & freqüente & $\mathrm{tr}$ \\
8 & Centraterum sp. & Perpétua & ocasional & $\mathrm{er}$ \\
9 & Chamaecrista bahiae & pau-ferro & ocasional & *av \\
10 & Cyperus lanceolatus & Tiriricão & abundante & $\mathrm{er}$ \\
11 & Crotalaria unifoliolata & xique-xique & ocasional & $\mathrm{er}$ \\
12 & Croton sp. & erva-de-rola II & ocasional & $\mathrm{er}$ \\
13 & Cnidoscolus urens & Urtiga & abundante & $\mathrm{er}$ \\
14 & Dalechampia scandens & Tamiarana & abundante & $\mathrm{tr}$ \\
15 & Digitaria insularis & capim-amargoso & ocasional & $\mathrm{er}$ \\
16 & Elaeis guineensis & Dendezeiro & ocasional & $\mathrm{pl}$ \\
17 & Emilia sagitatta & Pincel & ocasional & $\mathrm{er}$ \\
18 & Euphorbia brasiliensis & burra-leiteira & ocasional & $\mathrm{er}$
\end{tabular}


Tabela 4.7 - Listagem de espécies vegetais encontradas ao longo do transecto das armadilhas, na área de plantio do ano de 1992.

\begin{tabular}{|c|c|c|c|c|}
\hline $\mathbf{N}$. & Espécie & Nome comum & Ocorrência & Hábito \\
\hline 19 & Eugenia insipida & murta-branca & ocasional & *av \\
\hline 20 & Eugenia uniflora & batinga & ocasional & $a b$ \\
\hline 21 & Eupatorium laevigatum & aleluia & ocasional & $\mathrm{sb}$ \\
\hline 22 & Guazuma ulmifolia & mutamba & freqüente & $a b$ \\
\hline 23 & Guettarda platypoda & angélica & freqüente & $a b$ \\
\hline 24 & Hymenaea courbaril & jabotá & ocasional & *av \\
\hline 25 & Inga capitata & ingá-tripa & ocasional & *av \\
\hline 26 & Manilkara salzmannii & maçaranduba & freqüente & *av \\
\hline 27 & Ormosia arbórea & mucunã & freqüente & $\operatorname{tr}$ \\
\hline 28 & Passiflora sp.2 & maracujá-mochila & freqüente & $\operatorname{tr}$ \\
\hline 29 & Paspalum maritimum & capim-gengibre & abundante & er \\
\hline 30 & Polygala hebeclada & roxinha & freqüente & er \\
\hline 31 & Remirea maritima & alecrim & frequente & er \\
\hline 32 & Rhynchelytrum repens & capim-favorito & freqüente & er \\
\hline 33 & Richardia brasiliensis & avanço & freqüente & er \\
\hline 34 & Schranckia leptocarpa & malícia & ocasional & $\operatorname{tr}$ \\
\hline 35 & Senna sp. 1 & sena-bagaço & ocasional & $a b$ \\
\hline 36 & Solanum paludosusm & jurubeba-amarela & abundante & $a b$ \\
\hline 37 & Stylosanthes guianensis & meladinho & ocasional & er \\
\hline 38 & Tabebuia roseo-alba & peroba & freqüente & *av \\
\hline 39 & Tapirira guianensis & cupiúba & freqüente & *av \\
\hline 40 & Tocoyena selloana & jenipapo-bravo & abundante & $a b$ \\
\hline 41 & Trema micrantha & tamanqueiro & abundante & $a b$ \\
\hline 42 & Turnera ulmifolia & albina & freqüente & er \\
\hline 43 & Ziziphus joazeiro & juazeiro & freqüente & *av \\
\hline 44 & Zollernia ilicifolia & pau-santo & ocasional & *av \\
\hline 45 & Waltheria viscosissima & malva-falsa & ocasional & $s b$ \\
\hline 46 & Commelina nudiflora & erva-de-santa-luzia & ocasional & er \\
\hline 47 & Sida sp. 2 & chanana & frequente & er \\
\hline 48 & Centraterum sp. 2 & papaconha & raro & er \\
\hline 49 & Oxipetalum apendiculatum & maxixi-bravo & freqüente & $\operatorname{tr}$ \\
\hline 50 & Espécie não identificada & capim-da-mata & freqüente & er \\
\hline 51 & Clitoria sp. & clitória & freqüente & $\operatorname{tr}$ \\
\hline 52 & Paspalum conspersum & capim-milhã-do-brejo & raro & er \\
\hline 53 & Paspalum sp. & grama-da-mata & ocasional & er \\
\hline
\end{tabular}

Conclusão. Fonte: informação pessoal ${ }^{53}$

Legenda : Hábitos: $a v=$ árvore; $a b=$ arbusto; $s b=$ subarbusto; $\mathrm{er}=$ erva; $\mathrm{tr}=$ trepadeira; $\mathrm{pl}=$ palmeira. * as espécies arbóreas citadas comportam-se na área como arbustos devido ao curto tempo de plantio.

53 Dados coletados pelo biólogo Claudeci Santana da Silva - Assistente de Meio Ambiente da Mina do Guaju - Lyondell Chemicals Company, em 04 de outubro de 2002. 


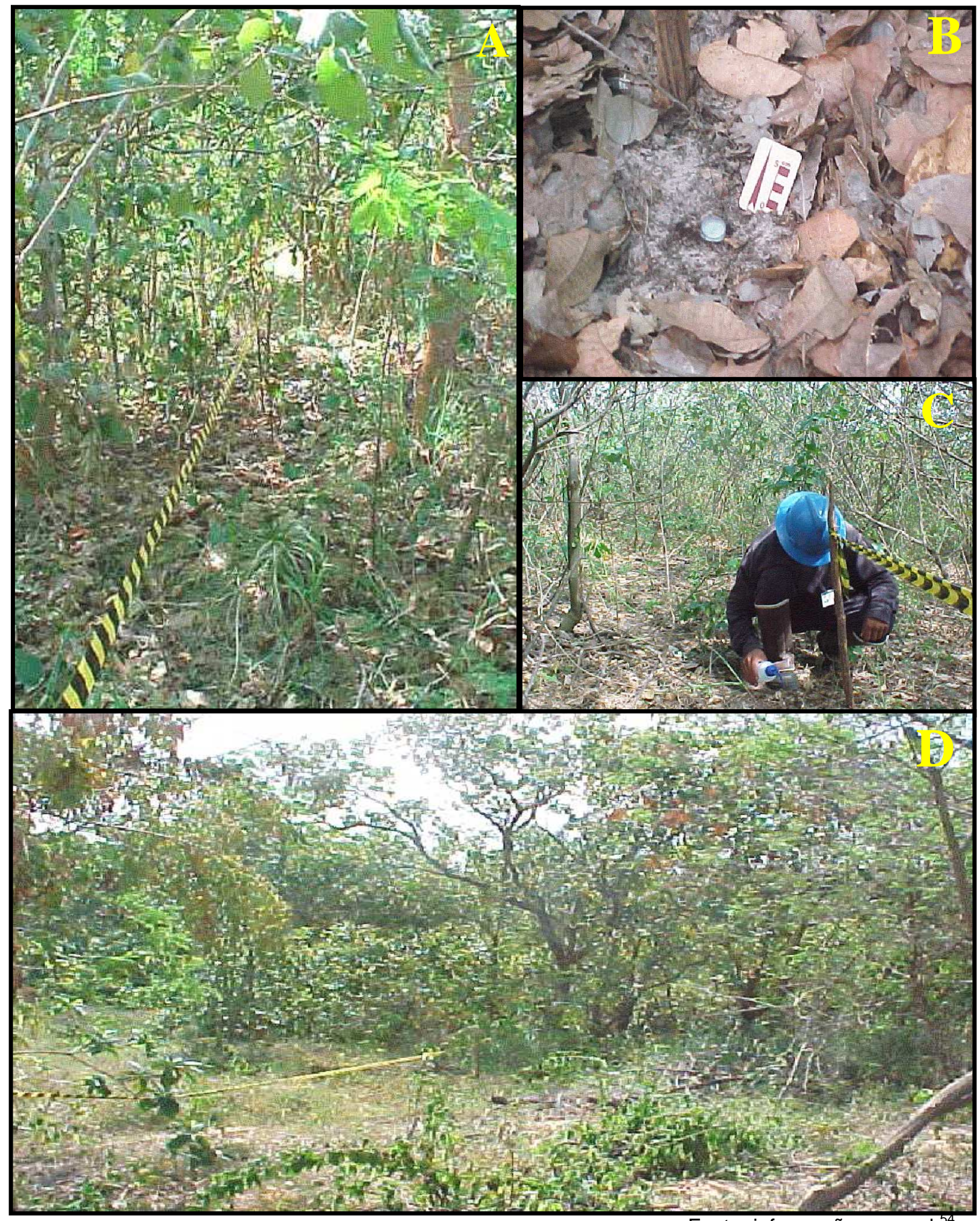

Fonte: informação pessoal ${ }^{3}$

Figura 30 - Fotos de detalhes da Área de plantio de 1992 (A92): A, C e D - porte da vegetação; B - presença de serapilheira.

${ }^{54}$ Fotos da coleção particular da autora, 25 de setembro de 2002. 
Com espalhamento do solo em 1994/1995, e plantio de mudas nos meses de abril a junho de 1995, a área apresenta vegetação arbustiva e dominância de espécies herbáceas, o porte médio dos arbustos é de 5 a 6 metros. Nestas áreas há um domínio do cajueiro, pois no local foi montado um experimento de plantio concentrado apenas desta espécie, visando averiguar o comportamento da regeneração natural das demais espécies nativas no sub-bosque. Além do cajueiro, temos na área boa densidade de jenipapo-bravo, que já se encontra em fase de frutificação, constituindo com o cajueiro os principais fornecedores de alimento para os representantes da fauna superior. Ocorrem ainda em boa quantidade juazeiro, mutamba, jurubeba-amarela e muitas outras plantas herbáceas e trepadeiras das famílias Convulvulaceae, Solanaceae, Rubiáceae, Poáceae.

A seguir, nas Tabela 4.8 e Figuras 31 , é possível observar uma tabela contendo a listagem de espécies vegetais encontradas ao longo do transceto onde as armadilhas foram dispostas e fotos da área de plantio do ano de 1995, respectivamente.

Tabela 4.8 - Listagem de espécies vegetais encontradas ao longo do transecto das armadilhas, na área de plantio do ano de 1995.

\begin{tabular}{clllc}
\hline N. & Espécie & Nome comum & Ocorrência & Hábito \\
\hline 1 & Anacardium occidentale & Cajueiro & abundante & $\mathrm{ab}$ \\
2 & Byrsonima gardneriana & murici-da-praia & freqüente & $\mathrm{ab}$ \\
3 & Byrsonima sericea & murici-pitanga & raro & $\mathrm{ab}$ \\
4 & Borreria verticillata & vassourinha-de-botão & freqüente & $\mathrm{er}$ \\
5 & Britoa triflora & Guabiraba & ocasional & ${ }^{*} \mathrm{av}$ \\
6 & Cassia uniflora & amendoim-da-praia & ocasional & $\mathrm{er}$ \\
7 & Centraterum sp. & Perpétua & raro & $\mathrm{er}$ \\
8 & Chamaecrista bahiae & pau-ferro & ocasional & *av \\
9 & Cnidoscolus urens & Urtiga & freqüente & $\mathrm{er}$ \\
10 & Croton lobatus & erva-de-rola & freqüente & $\mathrm{er}$ \\
11 & Croton sp. & erva-de-rola II & freqüente & $\mathrm{er}$ \\
12 & Cyperus lanceolatus & Tiriricão & freqüente & $\mathrm{er}$
\end{tabular}


Tabela 4.8 - Listagem de espécies vegetais encontradas ao longo do transecto das armadilhas, na área de plantio do ano de 1995.

\begin{tabular}{|c|c|c|c|c|}
\hline N. & Espécie & Nome comum & Ocorrência & Hábito \\
\hline 13 & Dalechampia scandens & Tamiarana & freqüente & $\operatorname{tr}$ \\
\hline 14 & Desmodium incanum & carrapicho-beiço-de-boi & ocasional & er \\
\hline 15 & Emilia sagitatta & Pincel & ocasional & er \\
\hline 16 & Eugenia uniflora & Batinga & ocasional & $a b$ \\
\hline 17 & Euphorbia pilulifera & burra-leiteira & ocasional & er \\
\hline 18 & Guazuma ulmifolia & Mutamba & freqüente & $a b$ \\
\hline 19 & Ipomoea sp. & corda-de-viola & ocasional & $\operatorname{tr}$ \\
\hline 20 & Lantana camara & Chumbinho & ocasional & $\mathrm{sb}$ \\
\hline 21 & Manilkara salzmannii & Maçaranduba & ocasional & *av \\
\hline 22 & Ormosia arbórea & Mucunã & freqüente & $\operatorname{tr}$ \\
\hline 23 & Passiflora sp.2 & maracujá-mochila & freqüente & $\operatorname{tr}$ \\
\hline 24 & Polygala hebeclada & Roxinha & ocasional & er \\
\hline 25 & Remirea maritima & alecrim-da-praia & freqüente & er \\
\hline 26 & Rhynchelytrum repens & capim-favorito & ocasional & er \\
\hline 27 & Richardia brasiliensis & Poaia & ocasional & er \\
\hline 28 & Setaria vulpiseta & capim-rabo-de-raposa & freqüente & er \\
\hline 29 & Solanum paludosusm & jurubeba-amarela & abundante & $a b$ \\
\hline 30 & Solanum paniculatum & jurubeba-branca & ocasional & $\mathrm{sb}$ \\
\hline 31 & Tabebuia avellanedae & pau-d'arco-roxo & ocasional & *av \\
\hline 32 & Tapirira guianensis & Cupiúba & freqüente & *av \\
\hline 33 & Tocoyena selloana & jenipapo-bravo & abundante & $a b$ \\
\hline 34 & Turnera ulmifolia & Albina & ocasional & er \\
\hline 35 & Ziziphus joazeiro & Juazeiro & abundante & *av \\
\hline 36 & Zollernia ilicifolia & pau-santo & ocasional & *av \\
\hline 37 & Waltheria viscosissima & malva-falsa & ocasional & $\mathrm{sb}$ \\
\hline 38 & Ocotea gardneri & louro-de-cheiro & ocasional & *av \\
\hline 39 & Commelina nudiflora & erva-de-santa-luzia & ocasional & er \\
\hline 40 & Sida sp. 2 & Chanana & ocasional & er \\
\hline 41 & Sida sp. 3 & malva-roxa & ocasional & $s b$ \\
\hline 42 & Polygala sp. & roxinha-folha-fina & raro & er \\
\hline 43 & Espécie não identificada & capim-da-mata & ocasional & er \\
\hline 44 & Merremia glabra & jetirana-de-batata & freqüente & $\operatorname{tr}$ \\
\hline
\end{tabular}

Legenda: Hábitos: $a v=$ árvore; $a b=$ arbusto; $s b=$ subarbusto; er = erva; $\operatorname{tr}=$ trepadeira. ${ }^{*}$ as espécies arbóreas citadas comportam-se na área como arbustos devido ao curto tempo do plantio.

55 Dados coletados pelo biólogo Claudeci Santana da Silva - Assistente de Meio Ambiente da Mina do Guaju - Lyondell Chemicals Company, em 04 de outubro de 2002. 


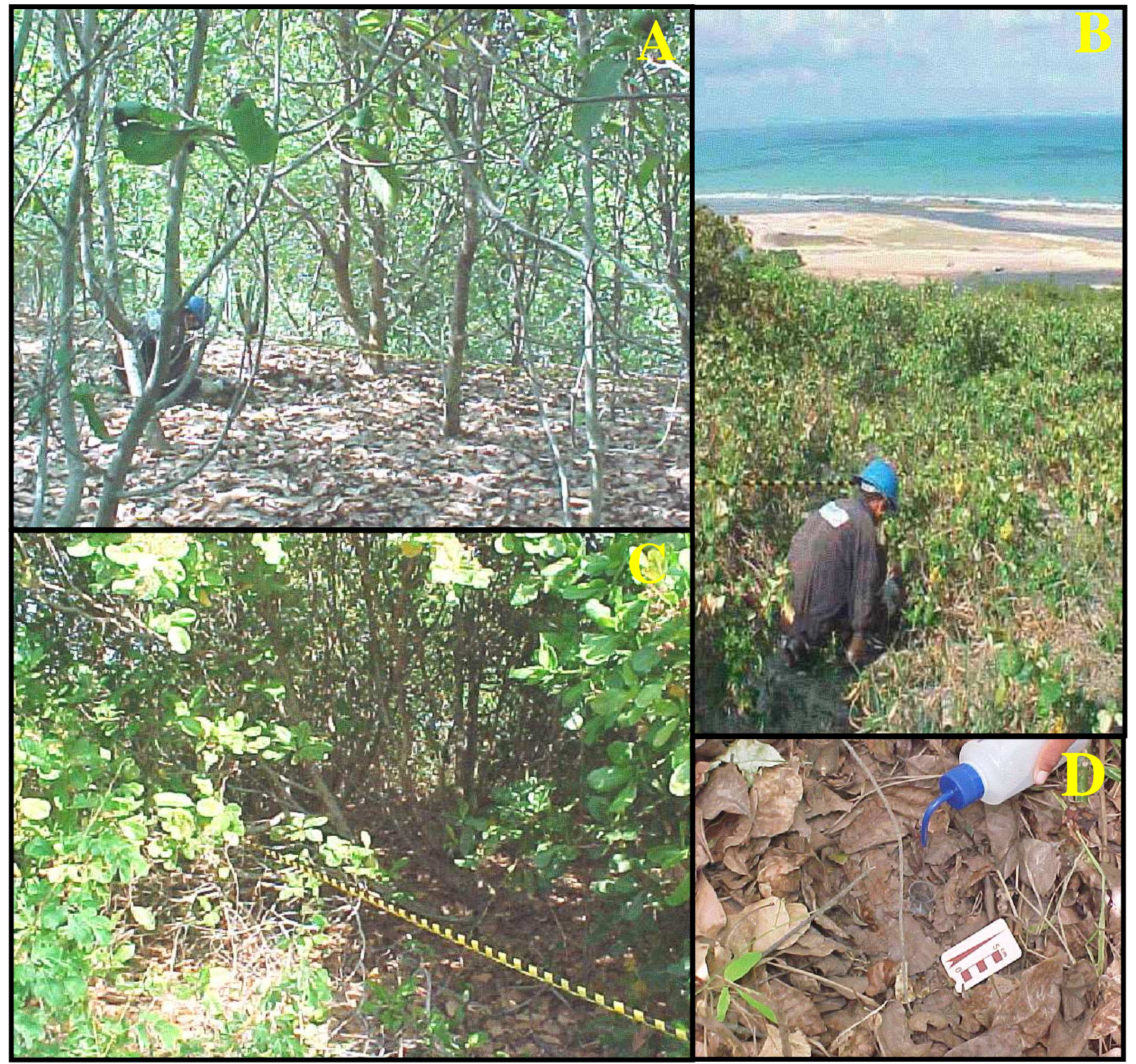

Fonte: informação pessoal ${ }^{56}$.

Figura 31 - Fotos de detalhes da Área de plantio de 1995 (A95): A, B e C - porte da vegetação; $\mathrm{D}$ - presença de serapilheira.

\footnotetext{
${ }^{56}$ Fotos da coleção particular da autora, 25 de setembro de 2002.
} 
Devido ao pouco tempo de plantio as árvores plantadas estão com porte de, no máximo, 3 metros de altura, ficando o porte médio em torno de 1,50 metros. Devido a grande insolação propiciada pelo pequeno porte dos arbustos, há um domínio total de espécies herbáceas, da família Poaceae (gramíneas) especialmente os gêneros Rynchelintrum; Setaria, Cynodon e Digitaria, vale lembrar que a maioria dessas gramíneas é temporária e no período seco do ano formam um grande "tapete" de capim seco sobre o solo. Ocorre também em grande quantidade a leguminosa temporária mata-pasto - Cassia tora.

A seguir, na Tabela 4.9 e na Figura 32, é possível observar uma tabela contendo a listagem de espécies vegetais encontradas ao longo do transceto onde as armadilhas foram dispostas e fotos da área de plantio do ano de 2000, respectivamente.

Tabela 4.9 - Listagem de espécies vegetais encontradas na área de plantio do ano de 2000.

\begin{tabular}{clllc}
\hline N. & Espécie & Nome comum & Ocorrência & Hábito \\
\hline 1 & Anacardium ocidentalle & Cajueiro & abundante & $\mathrm{ab}$ \\
2 & Borreria verticillata & vassourinha-de-botão & freqüente & $\mathrm{er}$ \\
3 & Canavalia rosea & fava-de-boi-miúda & ocasional & $\mathrm{tr}$ \\
4 & Cassia tora & mata-pasto & abundante & $\mathrm{sb}$ \\
5 & Cassia uniflora & amendoim-da-praia & ocasional & $\mathrm{er}$ \\
6 & Chamaecrista bahiae & pau-ferro & ocasional & *av \\
7 & Cnidoscolus urens & Urtiga & abundante & $\mathrm{er}$ \\
8 & Commelina benghalensis & Trapoeraba & freqüente & $\mathrm{er}$ \\
9 & Crotalaria trifoliata & Crotalaria & ocasional & $\mathrm{er}$ \\
10 & Croton lobatus & erva-de-rola & freqüente & $\mathrm{er}$ \\
11 & Cynodon dactylon & grama-de-burro & abundante & $\mathrm{er}$ \\
12 & Dactiloctenium Aegiptium & capim-mão-de-sapo & ocasional & $\mathrm{er}$
\end{tabular}


Tabela 4.9 - Listagem de espécies vegetais encontradas na área de plantio do ano de 2000.

\begin{tabular}{llllc}
\hline N. & Espécie & Nome comum & Ocorrência & Hábito \\
\hline 13 & Desmodium incanum & carrapicho-beiço-de-boi & freqüente & $\mathrm{er}$ \\
14 & Digitaria insularis & capim-amargoso & abundante & $\mathrm{er}$ \\
15 & Guettarda platypoda & Angélica & ocasional & $\mathrm{ab}$ \\
16 & Passiflora foetida & maracujá-estalo & ocasional & $\mathrm{tr}$ \\
17 & Passiflora sp.2 & maracujá-mochila & ocasional & $\mathrm{tr}$ \\
18 & Pithecelobium foliolosum & jurema-branca & ocasional & $\mathrm{ab}$ \\
19 & Rhynchelytrum repens & capim-favorito & abundante & $\mathrm{er}$ \\
20 & Schranckia leptocarpa DC. & Malícia & ocasional & $\mathrm{tr}$ \\
21 & Simaba ferruginea St. Hil. & Cajarana & ocasional & *av \\
22 & Solanum mauritianum Scop. & Jussara & freqüente & $\mathrm{sb}$ \\
23 & Solanum paniculatum L. & jurubeba-branca & freqüente & $\mathrm{sb}$ \\
24 & Stylosanthes guianensis (Aubl.) Sw & Meladinho & freqüente & $\mathrm{er}$ \\
25 & Tabebuia avellanedae Lors. ex Griseb. & pau-d'arco-roxo & freqüente & $\mathrm{ab}$ \\
26 & Tocoyena selloana Schum. & jenipapo-bravo & abundante & $\mathrm{ab}$ \\
27 & Turnera ulmifolia L. & Albina & freqüente & $\mathrm{er}$ \\
28 & Waltheria viscosissima St. Hil. & malva-falsa & freqüente & $\mathrm{sb}$ \\
29 & Ziziphus joazeiro Mart. & Juazeiro & freqüente & *av \\
30 & Sida sp. 2 & Chanana & ocasional & $\mathrm{tr}$ \\
31 & Convulvulos sp. & corda-de-viola & ocasional & $\mathrm{tr}$ \\
32 & Sidasp. 3 & Malvão & ocasional & $\mathrm{sb}$ \\
33 & Commelina nudiflora & erva-de-santa-luzia & ocasional & $\mathrm{er}$ \\
34 & Digitaria ciliaris & capim-de-roça & abundante & $\mathrm{er}$ \\
\hline
\end{tabular}

Legenda: Hábitos: av = árvore; $\mathrm{ab}=$ arbusto; $\mathrm{sb}=$ subarbusto; $\mathrm{er}=\mathrm{erva}$; $\mathrm{tr}=$ trepadeira. ${ }^{*}$ as espécies arbóreas citadas comportam-se na área como arbustos devido ao curto tempo do plantio.

57 Dados coletados pelo biólogo Claudeci Santana da Silva - Assistente de Meio Ambiente da Mina do Guaju - Lyondell Chemicals Company, em 04 de outubro de 2002. 


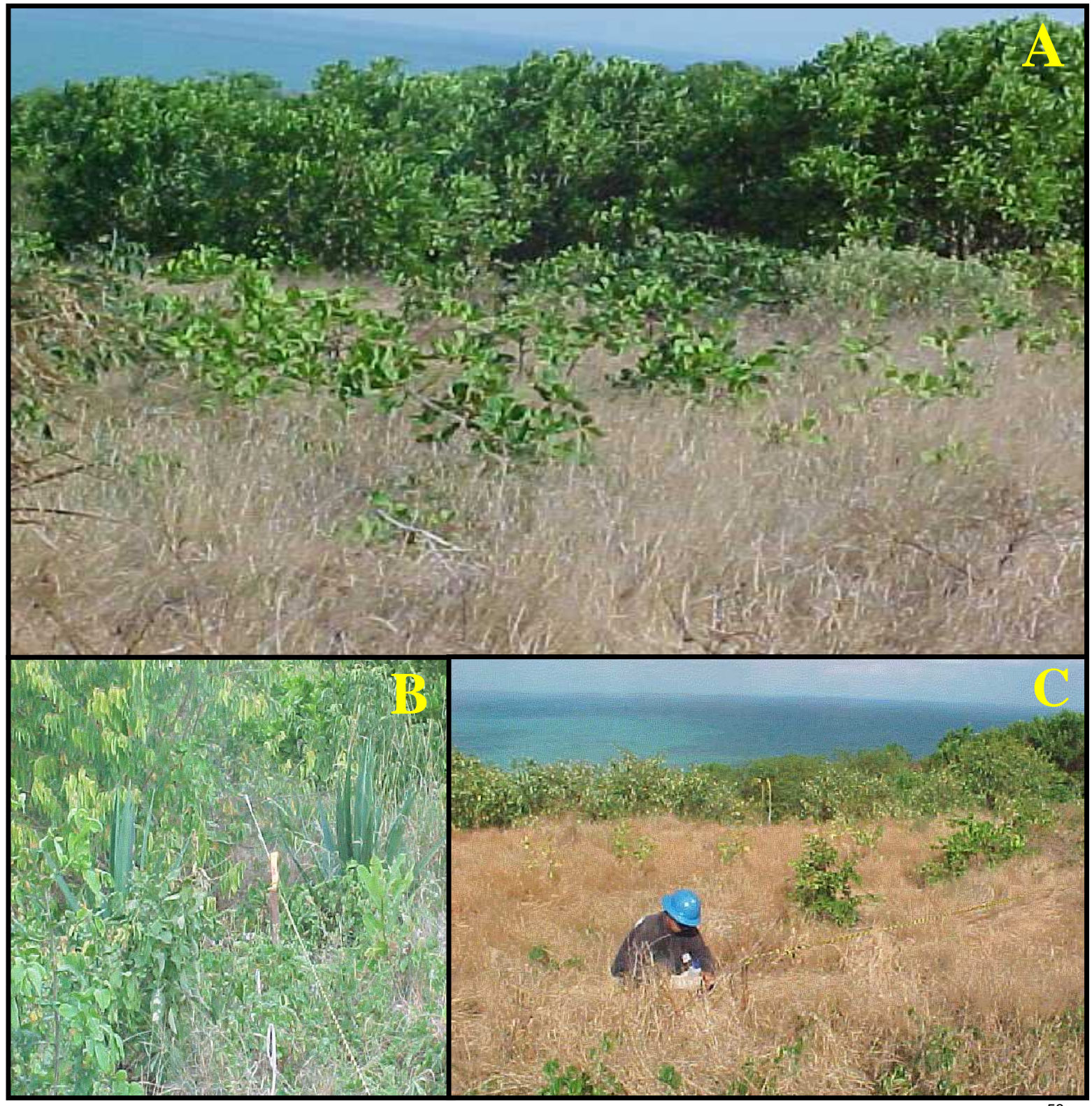

Fonte: informação pessoal ${ }^{58}$.

Figura 32 - Fotos de detalhes da Área de plantio de 2000 (A00): A, B, C - porte da vegetação.

${ }^{58}$ Fotos da coleção particular da autora, 25 de setembro de 2002. 


\subsection{COLETAS DE FORMIGAS}

Quanto à amostragem dos bioindicadores, mais especificamente das formigas, de acordo com o clima quente e úmido, as variações sazonais local, caracterizadas por uma estação seca no verão e chuvosa no inverno, considerando que a atividade das formigas aumenta nos períodos mais quente e úmido do ano, foram definidos três datas ao longo de um ano, ou seja, os meses de setembro/2002, dezembro/2002 e março/2003, para a realização das coletas.

Cada área de coleta foi tratada com 20 armadilhas, as quais foram dispostas ao longo de um transecto, distando cerca de 10 metros uma das outras. Os pontos da primeira armadilha (P1) e da última armadilha (P20) de cada transecto foram marcados em GPS (Global System Position) com coordenadas UTM (Tabela 4.10).

Tabela 4.10 - Coordenadas UTM dos pontos de coletas.

\begin{tabular}{cccc}
\hline ÁREAS & PONTOS & $\mathbf{X}$ & $\mathbf{Y}$ \\
\hline \multirow{2}{*}{ AC1 } & P1 & 9277421,8851 & 282240,3664 \\
& P20 & 9277439,8198 & 282440,5326 \\
AC2 & P1 & 9277626,0248 & 282192,0165 \\
& P20 & 9277506,5208 & 282031,6457 \\
A89 & P1 & 9281763,6384 & 280742,0806 \\
& P20 & 9281867,1959 & 280913,1824 \\
A92 & P1 & 9281911,0428 & 281458,5192 \\
& P20 & 9282108,8911 & 281500,0133 \\
A95 & P1 & 9282224,2195 & 281750,9005 \\
& P20 & 9282187,0091 & 281947,4088 \\
A00 & P1 & 9281828,5169 & 281972,5693 \\
& P20 & 9281670,8465 & 282095,6141 \\
\hline
\end{tabular}

Fonte: informação pessoal ${ }^{59}$

Legenda: Legenda: $\mathrm{AC1}$ =Áreas Controle 1; $\mathrm{AC2}=$ Áreas Controle 2; A89=Área de Plantio 1989; A92=área de Plantio 1992; A95=Área de Plantio 1995; A00=Área de Plantio 2000. P1=Ponto da armadilha 1; P20=Ponto da armadilha 20.

Visando facilitar o retorno ao local exato de cada armadilha, cada ponto de coleta foi marcado com piquetes numerados, fixados em frente a cada armadilha.

\footnotetext{
${ }^{59}$ Dados fornecidos pelo Setor de Meio Ambiente da Mina do Guaju - Lyondell Chemicals Company,
} em 24 de abril de 2007. 
Todos os piquetes de uma mesma área foram interligados por fitas coloridas (amarelo e preto) conforme é possível observar na Figura 33.

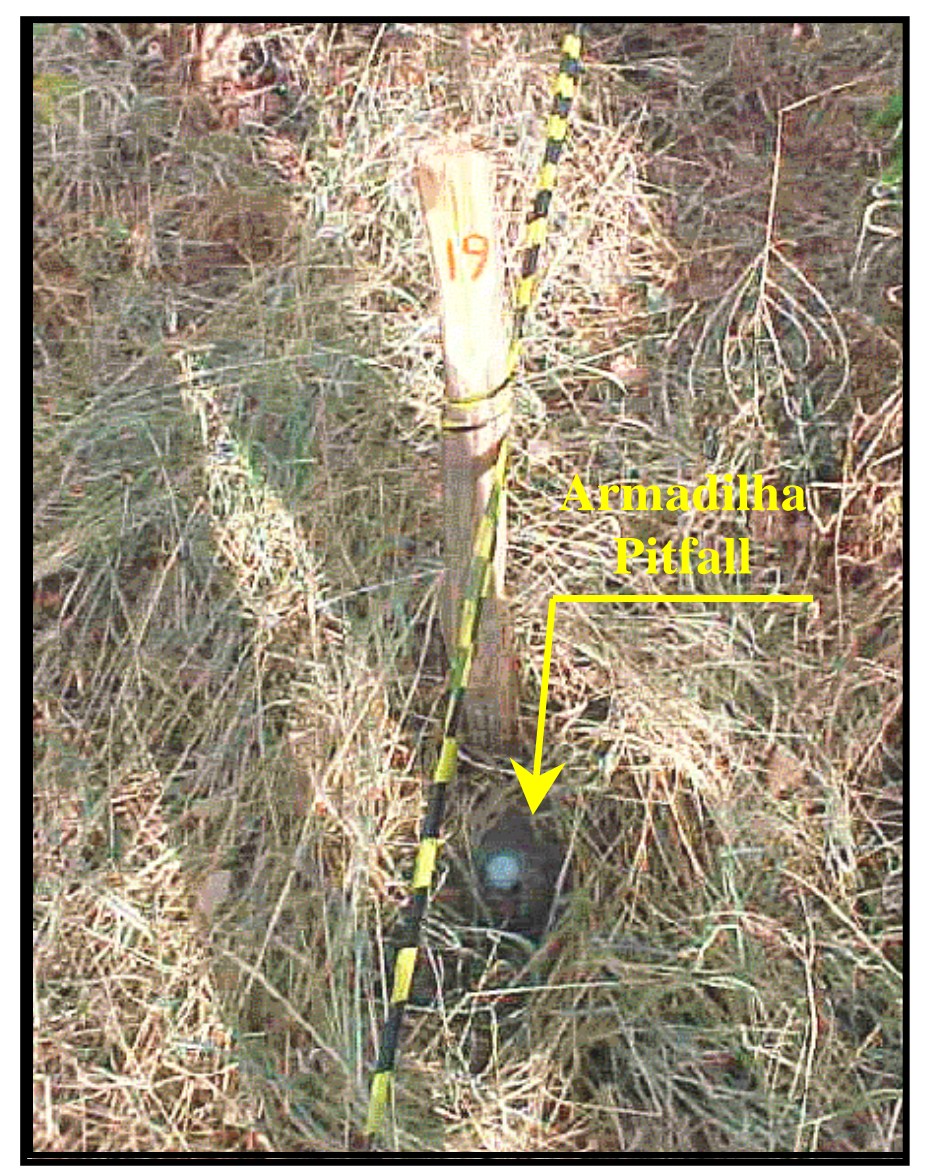

Fonte: informação pessoal ${ }^{60}$.

Figura 33 - Detalhe das armadilhas demarcadas com piquetes e fitas, no campo.

Para cada coleta, as armadilhas foram montadas em todas as áreas, ao longo de oito dias, seguindo um cronograma de campo pré-determinado, registrado na Tabela 4.11, sendo necessários dois dias para a fixação de todas as armadilhas no campo, seguidos de dois dias de amortização, respeitando a normalização do ambiente. Apenas no quinto dia é que as armadilhas receberam tratamento com solução de água e detergente e após $48 \mathrm{~h}$ do tratamento - período de captura dos bioindicadores - todas as armadilhas foram recolhidas do campo.

\footnotetext{
${ }^{60}$ Fotos da coleção particular da autora, 21 de março de 2003.
} 
Tabela 4.11 - Cronograma das Atividades de Campo, seguidas para a Mina do Guaju.

\begin{tabular}{|c|c|c|c|c|c|c|c|c|}
\hline & $1^{\circ} \mathrm{dia}$ & $2^{\circ}$ dia & $3^{\circ}$ dia & $4^{\circ} \mathrm{dia}$ & $5^{\circ} \mathrm{dia}$ & 60 dia & $7^{\circ} \mathrm{dia}$ & $8^{\circ}$ dia \\
\hline $\begin{array}{l}\text { 1. Montagem das } \\
\text { armadilhas no campo }\end{array}$ & $\mathbf{x}$ & X & & & & & & \\
\hline $\begin{array}{l}\text { 2. Tratamento das } \\
\text { armadilhas }\end{array}$ & & & & & $x$ & & & \\
\hline $\begin{array}{l}\text { 3. Recolhimento } \\
\text { das amostras } \\
\text { coletadas }\end{array}$ & & & & & & & & $x$ \\
\hline
\end{tabular}

Após o recolhimento de todas as armadilhas, o material coletado em cada ponto passou por um processo de triagem, onde, com o auxilio de uma lupa binocular, somente as formigas foram selecionadas, contadas e conservadas em recipientes bem fechados e devidamente etiquetados para posterior identificação (Figura 34).

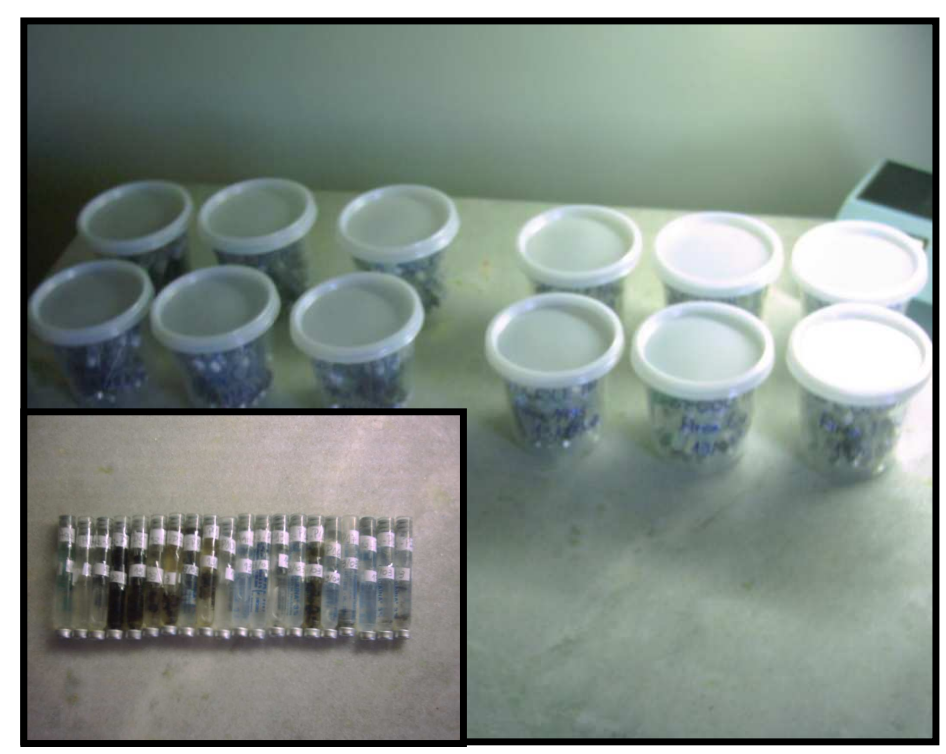

Fonte: informação pessoal ${ }^{62}$

Figura 34 - Conservação das formigas triadas.

A primeira coleta, realizada em setembro de 2002 foi identificada pelo Professor Dr. Harold G. Fowler, especialista e taxonomista na área de mirmecofauna, do Departamento de Ecologia, do Instituto de Biociências, Campus Universitário de Rio Claro, da Universidade Estadual Paulista "Julio de Mesquita

${ }^{61}$ Dados pessoais da autora, 05 de janeiro 2003.

62 Fotos da coleção particular da autora, 21 de março de 2003. 
Filho"; e as $2^{\circ}$ e $3^{\circ}$ coletas realizadas em dezembro de 2002 e março de 2003 consecutivamente, foram identificadas pelo Professor Dr. Heraldo Vasconcelos, phD em Ecologia pela University Colloge of North Wales, atual professor do Instituto de Biociências da Universidade Federal de Uberlândia, especialista em Interações entre Formigas e Plantas - Ecologia e Comunidade de Formigas.

Todas as áreas de coleta receberam o mesmo tratamento, com exceção do acréscimo de uma segunda área controle (AC2), que foi introduzida a partir da segunda coleta, a qual se julgou necessário, para a confirmação de que as condições físicas locais não estariam interferindo na baixa diversidade registrada na área controle 1 (AC1) da primeira coleta. $\mathrm{O}$ transecto da nova área foi localizado de forma a evitar a proximidade com a água das lagoas.

Após as identificações elaborou-se um catálogo como coleção de referência, onde, pelo menos um indivíduo de cada espécie coletada foi contemplado (Figura $35)$.

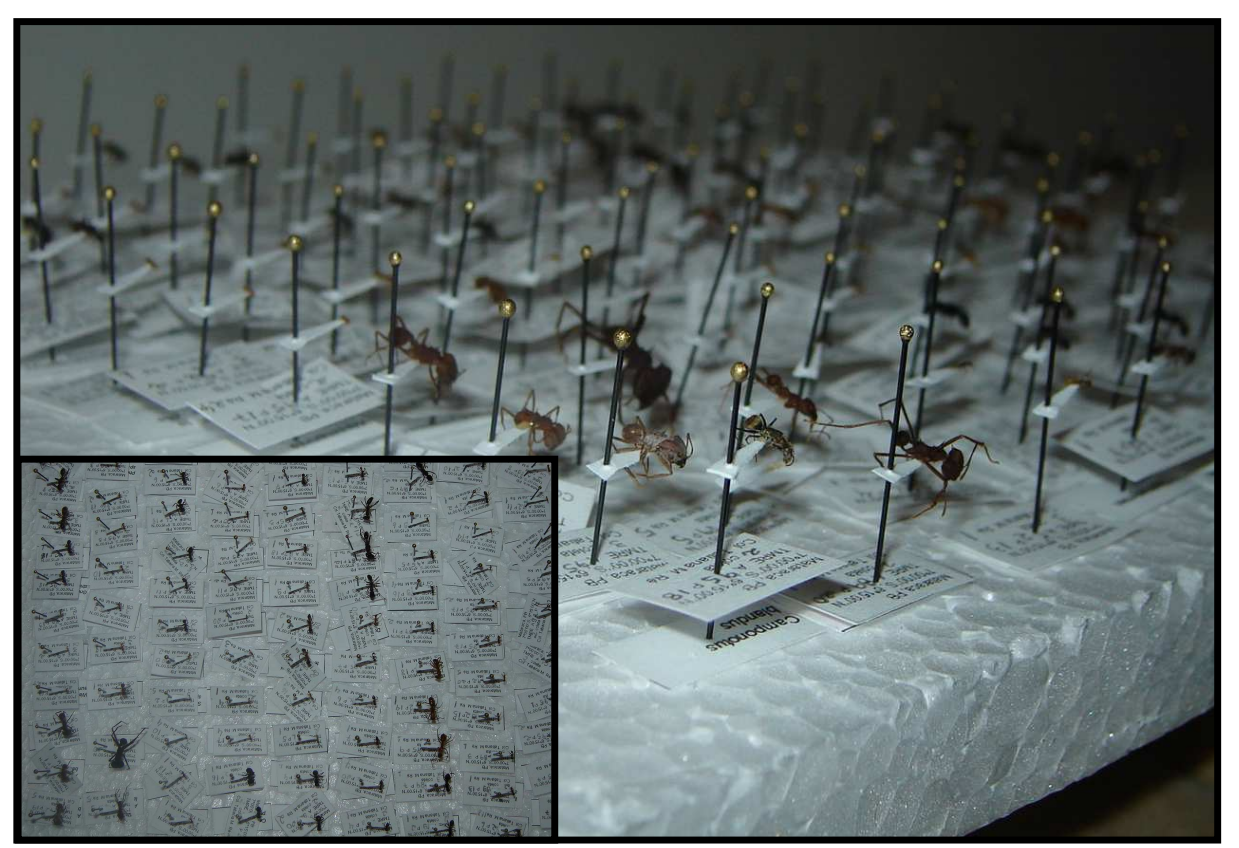

Fonte: informação pessoal ${ }^{63}$

Figura 35 - Coleção de referência - Catálogo de espécies de formigas.

\footnotetext{
${ }^{63}$ Fotos da coleção particular da autora, 21 de março de 2003.
} 


\section{CAPÍTULO 5}

\section{RESULTADOS, ANÁLISE E DISCUSSÃO}

\subsection{ANÁLISE DOS RESULTADOS}

Nessa pesquisa, os resultados foram analisados quanto à diversidade das espécies de formigas, pela afinidade e similaridades das áreas amostrais análise de agrupamento e análise dos grupos funcionais.

A diversidade de gêneros e de espécies foi analisada através da elaboração de uma tabela contendo a riqueza das espécies de formigas coletadas, um diagrama demonstrando a variação das riquezas ao longo das diferentes áreas, além de uma análise de freqüência dos gêneros ocorridos em cada área de coleta.

Para analisar os dados quanto à similaridade das áreas amostrais foi utilizado o programa estatístico "Affinity Analisys v 4.3" e para melhor visualizar a similaridade das áreas, realizou-se uma análise de agrupamento utilizando o programa estatístico "NTSYSpc versão 2.02i".

Os dados também foram analisados quanto à composição dos grupos funcionais e para essa análise foi realizada uma extrapolação dos grupos em duas classificações, realizadas em lugares distintos, classificados por ANDERSEN (2000) e BROWN JR (2000), cujos trabalhos foram desenvolvidos em habitat australiano, e uma outra extrapolação dos grupos funcionais classificados por BESTELMEYER e WIENS (1996), cujo trabalho foi desenvolvido em habitat do Chaco argentino.

Neste capítulo estão apresentados os resultados adquiridos com as três coletas de formigas, realizadas nas duas áreas de referência, onde não houve alterações antrópicas recentes (AC1 e AC2) e quatro áreas em diferentes etapas de recuperação (A89, A92, A95 e A00). Todas as coletas foram triadas, tratadas e as espécies identificadas, mas apenas as duas últimas coletas foram analisadas 
estatísticamente, conforme indicado no item 4.2 do Capítulo 4 (Aplicação Metodologica). A primeira coleta não foi considerada nas análises estatísticas, pois se trata de uma coleta identificada no início da pesquisa, pelo Professor Dr. Harold G. Fowler, a qual foi revisada e corrigida recentemente, mas, a perda do livro de registro com informações de localização das espécies identificadas impossibilitou a utilização dos dados.

\subsubsection{Análise de Diversidade}

Ao todo, foi coletado um total de 6.204 formigas onde, na primeira coleta foram registrados cinco subfamílias, 22 gêneros e 58 espécies em cinco áreas de coleta, representando 100 amostras e 2.490 formigas. Na segunda coleta foram registrados cinco subfamílias, 22 gêneros e 48 espécies em seis áreas de coletas, representando 120 amostras e 3.019 formigas. Já na terceira coleta foram registrados seis subfamílias, 20 gêneros e 42 espécies em seis áreas de coletas, representando 120 amostras e 653 indivíduos. Ao todo, foram coletadas seis subfamílias, 27 gêneros e 72 espécies de formigas (Tabela 5.1). A listagem de todas as espécies coletadas pode ser verificada no APÊNDICE A.

Tabela 5.1 - Número de formigas coletadas.

\begin{tabular}{cccccc}
\hline Coletas & Amostras & Subfamílias & Gêneros & Espécies & Indivíduos \\
\hline $\mathbf{1}^{\mathbf{0}}$ & 100 & 5 & 22 & 58 & 2.490 \\
$\mathbf{2}^{\mathbf{0}}$ & 120 & 5 & 22 & 48 & 3.019 \\
$\mathbf{3}^{\mathbf{0}}$ & 120 & 6 & 20 & 42 & 653 \\
TOTAL & 340 & 6 & 27 & 72 & 6.204 \\
\hline
\end{tabular}

A Tabela 5.2 apresenta o número de espécies de formigas encontradas em cada área de coleta, onde os valores representam o número total dos diferentes gêneros e espécies e o número de gêneros e espécies registradas em cada uma das coletas, registrados nas coletas 2 e 3 . 
Tabela 5.2 - Número de gêneros e espécies de formigas registradas em cada área de coleta.

\begin{tabular}{lcccccc}
\hline Local & $\begin{array}{c}\text { № GÊN. total } \\
\text { coletas 2 e 3 }\end{array}$ & $\begin{array}{c}\text { № SP total } \\
\text { coletas 2 e 3 }\end{array}$ & $\begin{array}{c}\text { № GÊN } \\
\text { coleta 2 }\end{array}$ & $\begin{array}{c}\text { № GÊN } \\
\text { coleta 3 }\end{array}$ & $\begin{array}{c}\text { № SP } \\
\text { coleta 2 }\end{array}$ & $\begin{array}{c}\text { № SP } \\
\text { coleta 3 }\end{array}$ \\
\hline AC1 & 15 & 25 & 12 & 08 & 18 & 14 \\
AC2 & 15 & 25 & 12 & 12 & 16 & 18 \\
A89 & 19 & 28 & 17 & 10 & 24 & 15 \\
A92 & 13 & 23 & 12 & 08 & 22 & 10 \\
A95 & 13 & 30 & 11 & 08 & 27 & 14 \\
A00 & 10 & 14 & 08 & 09 & 10 & 11 \\
\hline
\end{tabular}

Legenda: $\mathrm{AC} 1$ = área de controle 1; $\mathrm{AC2}$ = área de controle 2; $\mathrm{A} 89$ = área de plantio de 1989; A92 = área de plantio de 1992; A95 = área de plantio de 1995; A00 = área de plantio de 2000. № SP = número de espécies, e № GÊN. = número de gêneros.

Analisando a Tabela 5.2 é possível visualizar um menor número de espécies para a área 2000, onde foram registradas apenas 14 espécies, enquanto nas demais áreas havia mais de 20 espécies, o que é perfeitamente justificável por se tratar de uma área com plantio recente, ou seja, em estágio inicial de recuperação. Em compensação, o maior número de espécies foi registrado na Área 1995 (A95), o que não era de se esperar, já que se trata de uma área com pouco tempo de recuperação, em relação às Áreas 1989 (A89) e 1992 (A92). Além disso, um menor número de espécies foi registrado nas Áreas Controle (AC1 e AC2), em relação à Área 1989, ou seja, a primeira área a ser recuperada.

Com exceção da A95, é possível visualizar um padrão de evolução em termos de riqueza de espécies, das áreas mais recentes (A00 com 14 espécies de formigas) em direção às áreas com evolução de sucessão mais avançada (A92 e A89 com 23 e 28 espécies de formigas respectivamente). A A95 apresentou a maior riqueza de espécies (30 espécies de formigas) e por apresentar tratamento de plantio de espécies vegetais diferenciado das demais áreas, esta deverá merecer atenção especial ao longo do monitoramento ambiental.

O uso de diagramas de acumulação de espécies ou ranque de abundância, segundo UNDERWOOD e FISHER (2006) são bastante úteis para visualizar diferenças entre os habitats em estágios específicos de sucessão. Para melhor visualizar a evolução dos gêneros e espécies encontradas nas áreas de amostragem, elaborou-se um diagrama com a evolução dessas áreas, em relação à quantidade de gêneros e espécies coletados, como podemos observar na Figura 36. 


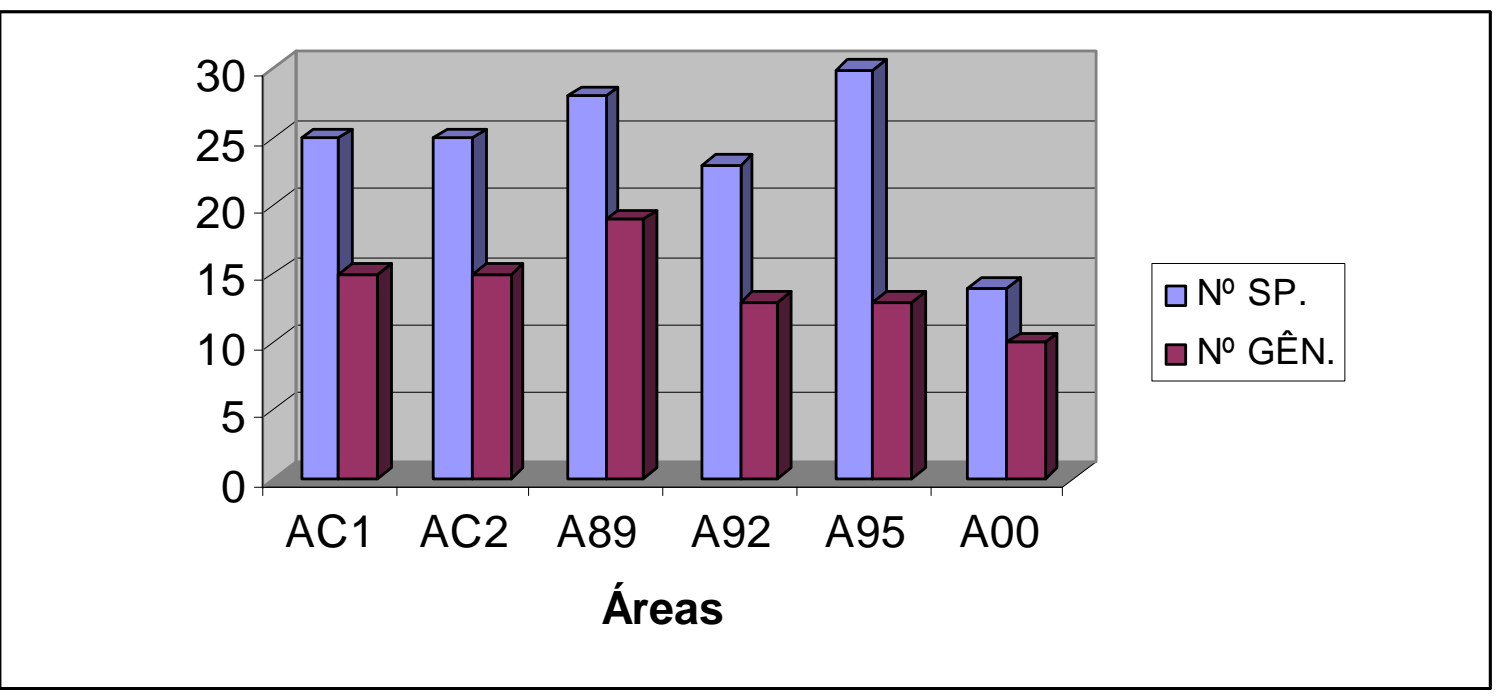

Legenda: $\mathrm{AC} 1$ = área controle $1, \mathrm{AC} 2$ = área controle $2, \mathrm{~A} 89$ = área de plantio iniciado no ano de 1989, A92 = área de plantio iniciado no ano de 1992, A95 = área de plantio iniciado no ano de 1995, $\mathrm{A} 00$ = área de plantio iniciado no ano de 2000 , № SP = número de espécies e № GÊN. = número de gêneros.

Figura 36 - Ranque de abundância de espécies e gêneros das áreas de coletas.

Analisando a Figura 36, podemos observar, de uma maneira geral, o aumento do número de gêneros e espécies, que acompanha a idade das áreas, ou seja, um menor número de gêneros e espécies na área mais recente em termos de recuperação $(\mathrm{A} 00)$ e, com exceção do número de espécies da $A 95$, um aumento destes números em direção à área A89. Já, nas áreas de referência, observa-se uma redução do número de gêneros e espécies, quando comparada com a área A89.

Para avaliar a diversidade local através da ocorrência dos principais gêneros de formigas em cada área de coleta, foi utilizada a freqüência de captura das formigas. Tal análise é considerada por ROMERO e JAFFÉ (1989; apud SILVESTRE; BRANDÃO, 2000), como o método mais indicado para estimativas de diversidade, no caso de insetos sociais, apresentando um melhor resultado quando comparado com a análise por meio do número de indivíduos coletados, visto que apenas um indivíduo forrageando é um indicador da probabilidade de encontrarmos uma colônia.

A freqüência de ocorrência dos gêneros registrados em cada área de coleta pôde ser verificada na Tabela 5.3. Tal freqüência foi calculada a partir da ocorrência de cada gênero em cada um dos pontos (armadilhas), ou seja, considerando que cada área teve 20 pontos de amostragem, cada gênero foi contado apenas uma vez 
de sua ocorrência em cada ponto. Assim, o gênero que ocorreu em todos os pontos possuirá freqüência máxima sempre igual a 20.

A freqüência relativa também pode ver visualizada na Tabela 5.3 (número entre parênteses) e foi calculada a partir da freqüência absoluta de cada gênero, através das seguintes formulas: $F A i=P i / P \times 100$ (onde $F A i=$ freqüência absoluta do gênero $\mathrm{i}, \mathrm{Pi}=$ número de pontos com ocorrência do gênero $i$, e $P=$ número total de pontos amostrados); e, $F R i=F A i / \Sigma F A \times 100$ (onde $F R i=$ freqüência relativa do gênero i, $\Sigma F A=$ somatória da freqüência absoluta para todos os gêneros de cada área).

Somente quatro dos 25 gêneros coletados (16\%) foram registrados em todas as áreas de coletas e cinco gêneros $(20 \%)$ foram representados por um único registro em 120 amostras de armadilhas "pitfalls". 
Tabela 5.3 - Freqüência dos gêneros de formigas nas áreas de coletas ${ }^{64}$.

\begin{tabular}{|c|c|c|c|c|c|c|c|}
\hline GÊNEROS & $\begin{array}{l}\mathrm{AC1} \\
\mathrm{N}=20\end{array}$ & $\begin{array}{l}\text { AC2 } \\
\mathrm{N}=20\end{array}$ & $\begin{array}{c}A 89 \\
N=20\end{array}$ & $\begin{array}{c}\mathrm{A} 92 \\
\mathrm{~N}=20\end{array}$ & $\begin{array}{l}\mathrm{A} 95 \\
\mathrm{~N}=20\end{array}$ & $\begin{array}{c}\mathrm{A} 00 \\
\mathrm{~N}=20\end{array}$ & $\begin{array}{c}\text { TOTAL } \\
\mathrm{N}=120\end{array}$ \\
\hline Acromyrmex & 0 & 0 & $1(1,37)$ & $1(1,16)$ & $5(7,25)$ & $6(10,17)$ & $13(3,07)$ \\
\hline Anochetus & 0 & 0 & $1(1,37)$ & 0 & 0 & 0 & $1(0,24)$ \\
\hline Atta laevigata & 0 & 0 & $2(2,74)$ & 0 & $1(1,45)$ & 0 & $3(0,71)$ \\
\hline Brachymyrmex & $1(1,37)$ & 0 & $1(1,37)$ & 0 & 0 & 0 & $2(0,47)$ \\
\hline Camponotus & $13(17,81)$ & $16(25,00)$ & $12(16,44)$ & $15(17,44)$ & $17(24,64)$ & $8(13,56)$ & $81(19,10)$ \\
\hline Cephalotes & 0 & $5(7,81)$ & $1(1,37)$ & 0 & 0 & $1(1,69)$ & $7(1,65)$ \\
\hline Crematogaster & $4(5,48)$ & $4(6,25)$ & $1(1,37)$ & 0 & $1(1,45)$ & $3(5,08)$ & $13(3,07)$ \\
\hline Cyphomyrmex & 0 & 0 & 0 & $6(6,98)$ & $2(2,90)$ & 0 & $8(1,89)$ \\
\hline Dorymyrmex & $1(1,37)$ & $2(3,13)$ & $6(8,22)$ & $8(9,30)$ & $5(7,25)$ & $17(28,81)$ & $39(9,20)$ \\
\hline Ectatomma & 0 & $1(1,56)$ & $5(6,85)$ & $8(9,30)$ & $7(10,14)$ & $3(5,08)$ & $24(5,66)$ \\
\hline Gnamptogenys & $6(8,22)$ & $1(1,56)$ & 0 & $1(1,16)$ & $2(2,90)$ & $2(3,39)$ & $12(2,83)$ \\
\hline Hylomyrma & $1(1,37)$ & 0 & $1(1,37)$ & 0 & 0 & 0 & $2(0,47)$ \\
\hline Hypoponera & $1(1,37)$ & 0 & 0 & 0 & 0 & 0 & $1(0,24)$ \\
\hline Labidus & 0 & $2(3,13)$ & $1(1,37)$ & 0 & 0 & 0 & $3(0,71)$ \\
\hline Leptothorax & 0 & 0 & 0 & $1(1,16)$ & 0 & 0 & $1(0,24)$ \\
\hline Linepithema & 0 & $1(1,56)$ & 0 & 0 & 0 & 0 & $1(0,24)$ \\
\hline Odontomachus & $1(1,37)$ & $1(1,56)$ & $2(2,74)$ & 0 & 0 & 0 & $4(0,94)$ \\
\hline Pachycondyla & $1(1,37)$ & 0 & 0 & 0 & 0 & 0 & $1(0,24)$ \\
\hline Paratrechina & 0 & $3(4,69)$ & $5(6,85)$ & $4(4,65)$ & $3(4,35)$ & 0 & $15(3,54)$ \\
\hline Pheidole & $20(27,40)$ & $19(29,69)$ & $15(20,55)$ & $15(17,44)$ & $11(15,94)$ & $13(22,03)$ & $93(21,93)$ \\
\hline Pseudomyrmex & $2(2,74)$ & 0 & $1(1,37)$ & 0 & $1(1,45)$ & $2(3,39)$ & $6(1,42)$ \\
\hline Solenopsis & $9(12,33)$ & $4(6,25)$ & $12(16,44)$ & $11(12,79)$ & $7(10,14)$ & $4(6,78)$ & $47(11,08)$ \\
\hline Strumigenys & $1(1,37)$ & $1(1,56)$ & $1(1,37)$ & $1(1,16)$ & 0 & 0 & $4(0,94)$ \\
\hline Trachymyrmex & $8(10,96)$ & $4(6,25)$ & $1(1,37)$ & $5(5,81)$ & 0 & 0 & $18(4,25)$ \\
\hline Wasmannia & $4(5,48)$ & 0 & $4(5,48)$ & $10(11,63)$ & $7(10,14)$ & 0 & $25(5,90)$ \\
\hline Total & $73(100)$ & $64(100)$ & $73(100)$ & $86(100)$ & $69(100)$ & $59(100)$ & $424(100)$ \\
\hline
\end{tabular}

Legenda: $\mathrm{AC} 1$ = Área Controle 1, AC2 = Áreas controle 2, A89 = Áreas com início da recuperação em 1989, A92 = Áreas com início da recuperação em 1992, A95 = Áreas com início da recuperação em 1995, $A 00$ = Áreas com início da recuperação em 2000. N = número de armadilhas presentes em cada área.

Em relação a $2^{0}$ e $3^{\circ}$ coletas, a subfamília Myrmicinae apresentou maior riqueza, com 33 espécies em 13 gêneros (gêneros mais abundantes Pheidole (8), Solenopsis (5), Strumigenys (4), Trachymyrmex (3) e Crematogaster (3)), seguida por Formicinae (12 em 3) (Camponotus foi o gênero mais rico apresentando 10 espécies), Ponerinae (7 em 5), Dolichoderinae (3 em 2), Pseudomyrmicinae (2 em 1) e Dorylinae (1 em 1) (APÊNDICE A).

Dentro de 424 espécies registradas, em 120 amostras, os gêneros com maior representatividade em relação a todas as áreas de coletas foram: Pheidole com 93 ocorrências, Camponotus (81), Solenopsis (47), Dorymyrmex (39), Wasmannia (25), e Ectatomma (24).

\footnotetext{
${ }^{64}$ Os números representam: o número total de amostras em que os gêneros foram registrados nas coletas 2 e 3 e os números entre parênteses indicam a freqüência relativa (\%) de cada gênero.
} 
Analisando a freqüência relativa dos gêneros de cada área amostrada temos:

1. Área Controle 1 (AC1) - dentro de 73 registros de 15 diferentes gêneros coletados em 20 amostras, os gêneros com maior representatividade foram: Pheidole com 20 ocorrências, Solenopsis (9), Trachymyrmex (8), Gnamptogenys (6), Crematogaster (4), Wasmannia (4) e Camponotus (13). A freqüência relativa dos gêneros da AC1 pode ser observada na Figura 37.

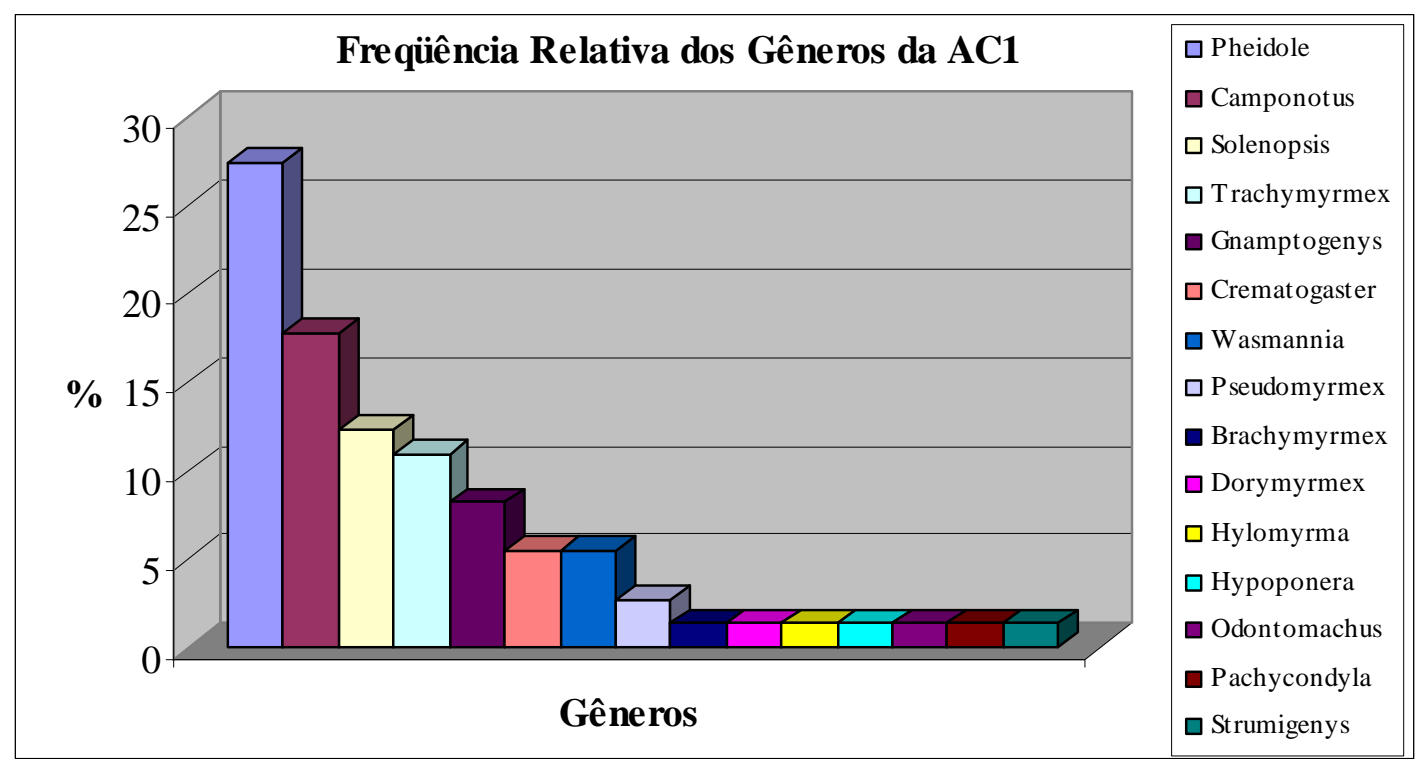

Figura 37 - Gráfico de freqüência relativa de todos os gêneros coletados na Área Controle 1 (AC1).

2. Área Controle 2 (AC2) - dentro de 64 registros de 14 diferentes gêneros coletados em 20 amostras, os gêneros com maior representatividade foram: Pheidole com 19 ocorrências; Camponotus (16); Cephalotes (5), Crematogaster (4), Solenopsis (4) e Trachymyrmex (4). A freqüência relativa dos gêneros da Área Controle 2 (AC2) podem ser observados na Figura 38. 


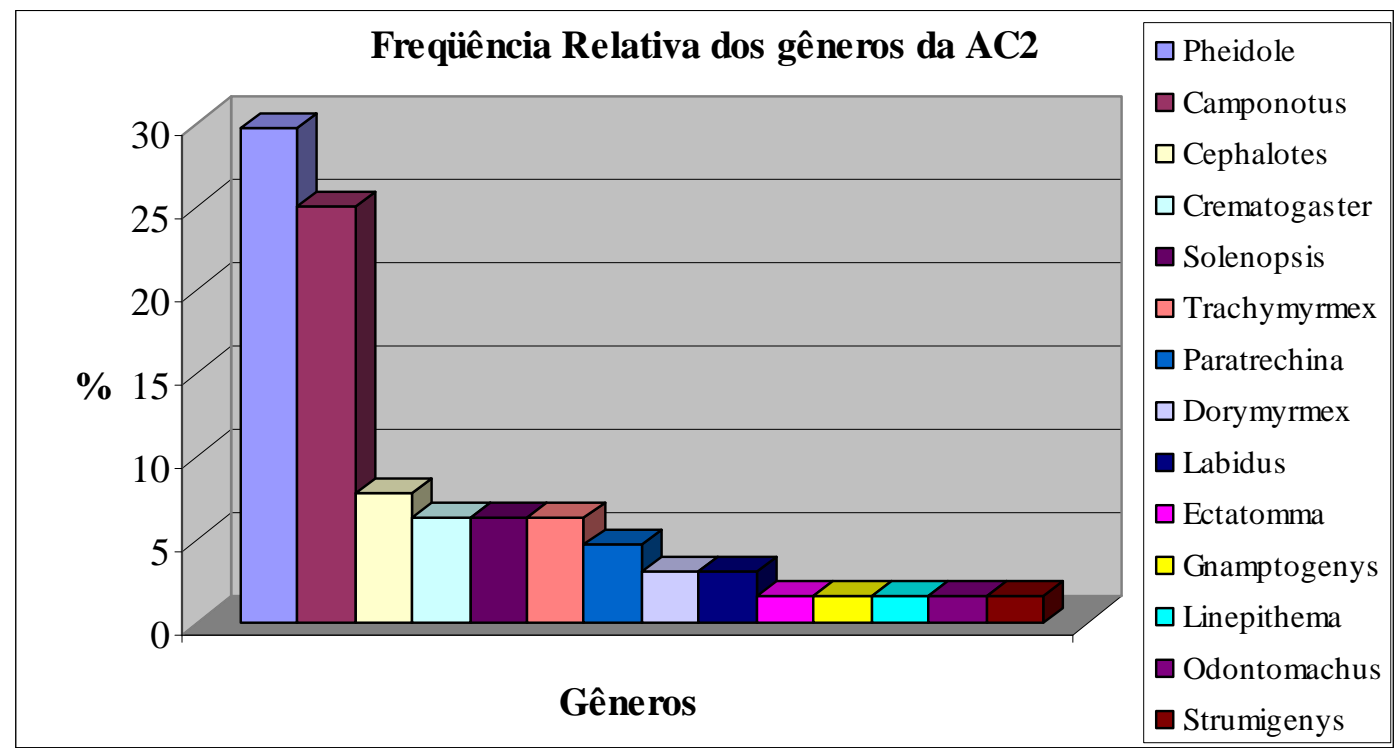

Figura 38 - Gráfico de freqüência relativa de todos os gêneros encontrados na Área Controle 2 (AC2).

3. Área de Plantio 1989 (A89) - dentro de 73 registros de 19 diferentes gêneros coletados em 20 amostras, os gêneros com maior representatividade foram: Pheidole com 15 ocorrências, Camponotus (12), Solenopsis (12), Dorymyrmex (6), Ectatomma (5), Paratrechina (5) e Wasmannia (4). A freqüência relativa dos gêneros da A89 pode ser observada na Figura 39.

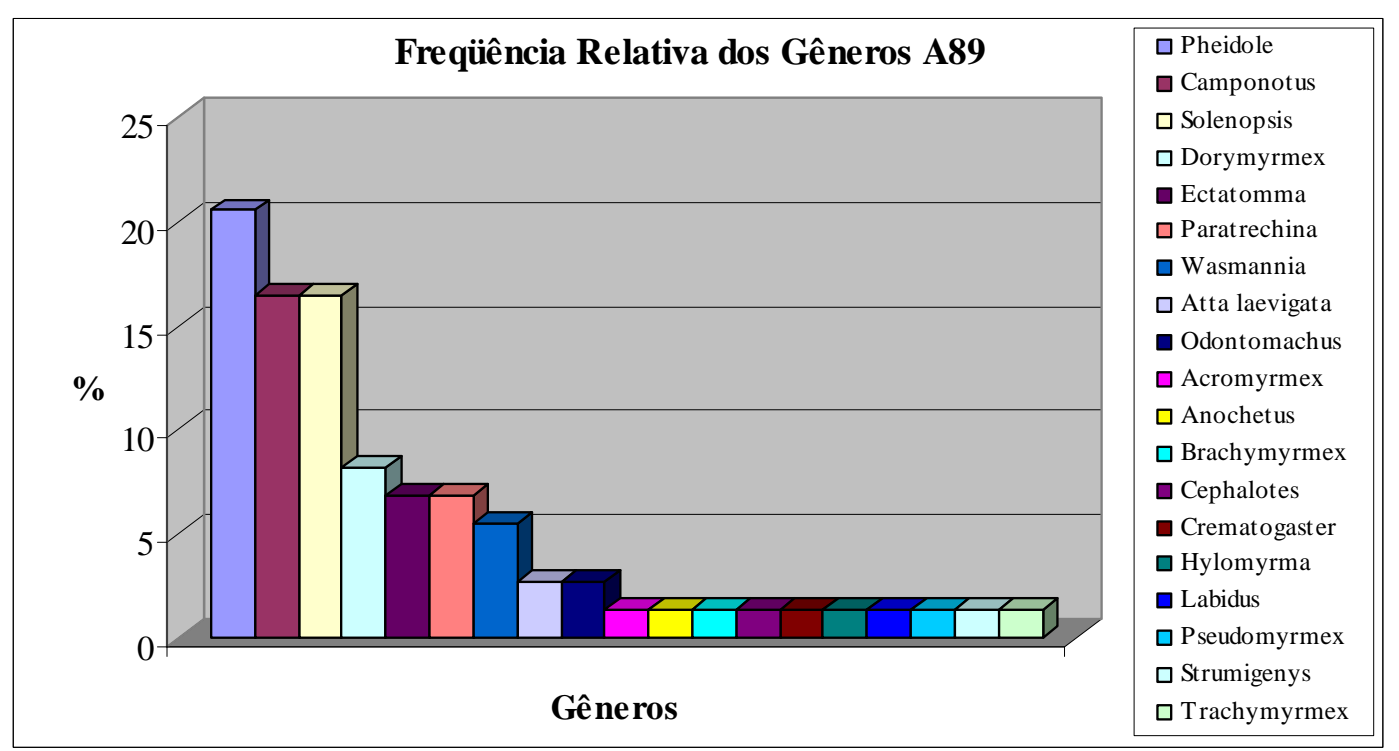

Figura 39 - Gráfico de freqüência relativa de todos os gêneros encontrados na Área de plantio 1989 (A89). 
4. Área de Plantio 1992 (A92) - dentro de 86 registros de 13 diferentes gêneros coletados em 20 amostras, os gêneros com maior representatividade foram: Camponotus e Pheidole ambas com 15 ocorrências, Solenopsis (11), Wasmannia (10) Dorymyrmex (8) Ectatomma (8), Cyphomyrmex (6), Trachymyrmex (5) e Paratrechina (4). A freqüência relativa dos gêneros da A92 pode ser observada na Figura 40.

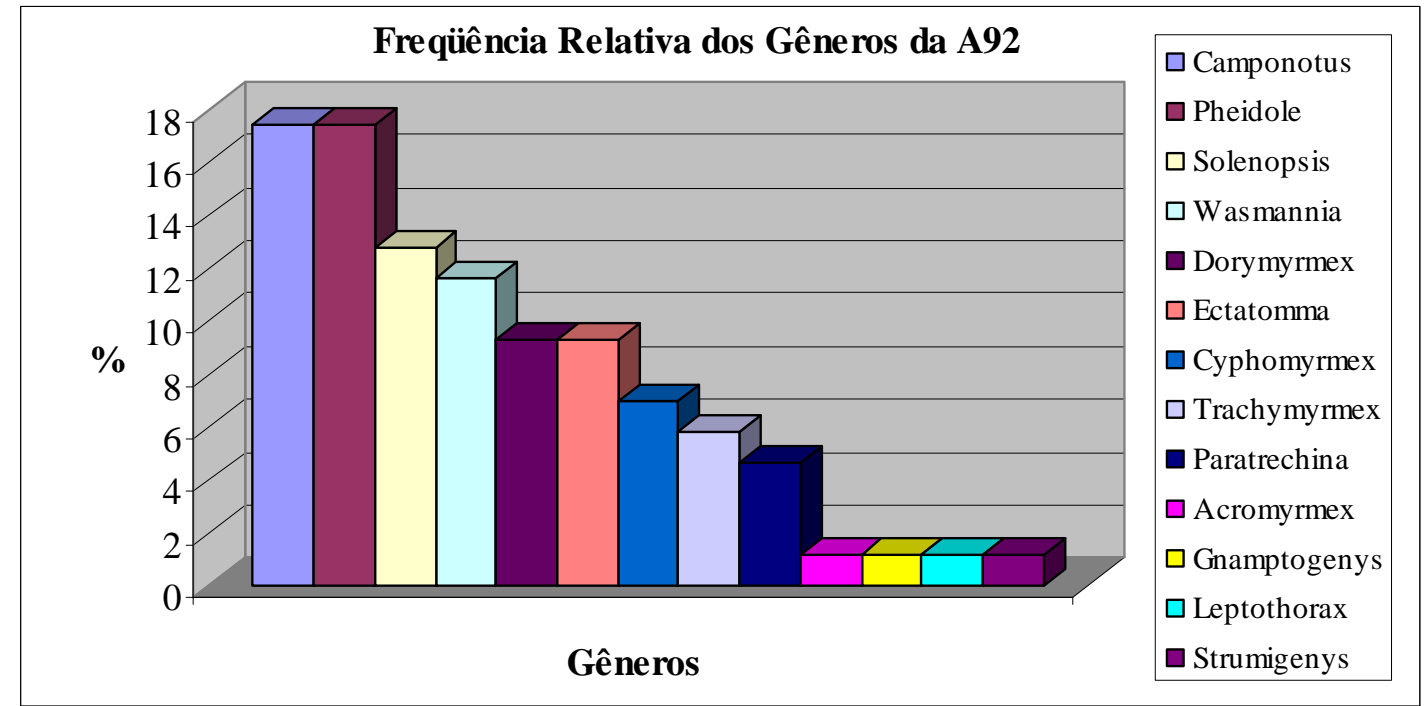

Figura 40 - Gráfico de freqüência relativa de todos os gêneros encontrados na Área de plantio 1992 (A92).

5. Área de Plantio 1995 (A95) - dentro de 69 registros de 13 diferentes gêneros coletados em 20 amostras, os gêneros com maior representatividade foram: Camponotus com 17 ocorrências, Pheidole (11), Ectatomma (7), Solenopsis (7), Wasmannia (7), Acromyrmex (5), Dorymyrmex (5) e Paratrechina (3). A freqüência relativa dos gêneros da A95 pode ser observada na Figura 41. 


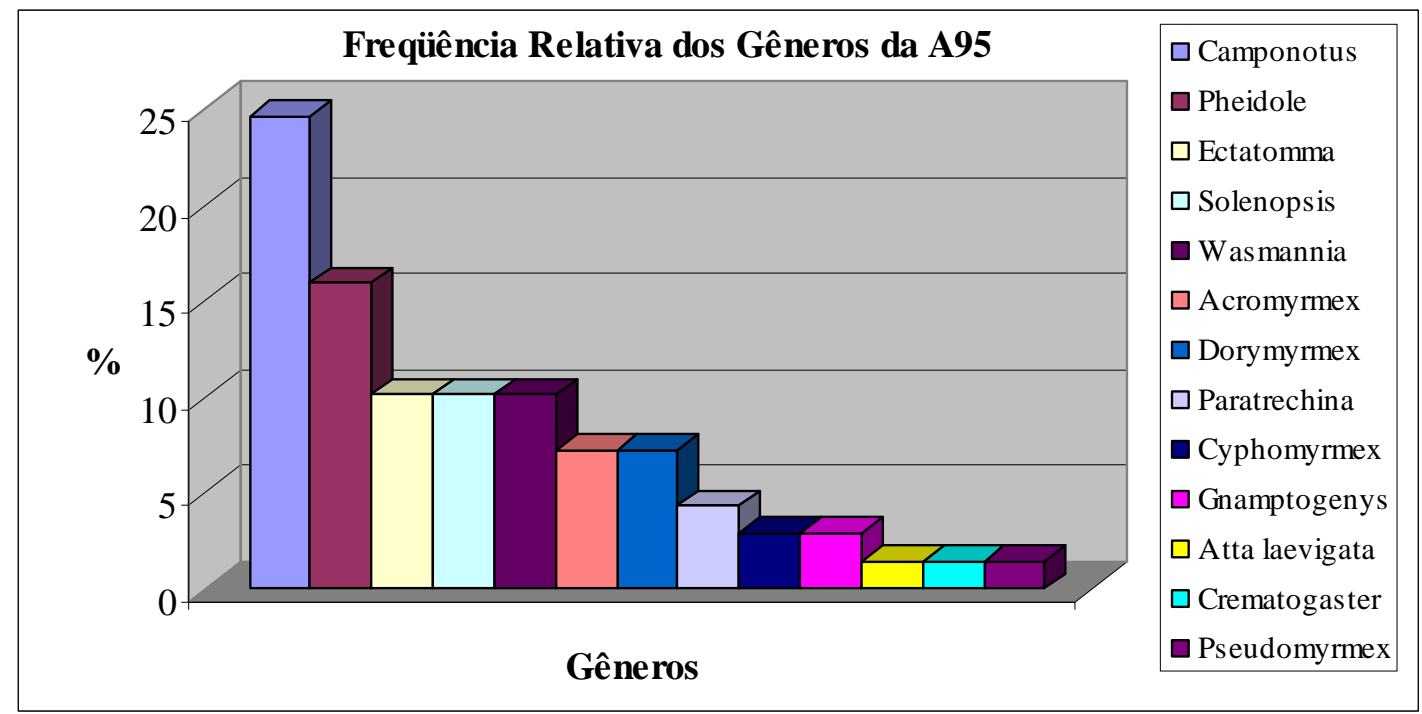

Figura 41 - Gráfico de freqüência relativa de todos os gêneros encontrados na Área de plantio 1995 (A95).

6. Área de Plantio 2000 (A00) - dentro de 59 registros de 10 diferentes gêneros coletados em 20 amostras, os gêneros com maior representatividade foram: Dorymyrmex com 17 ocorrências, Pheidole (13), Camponotus (8), Acromyrmex (6) e Solenopsis (4). A freqüência relativa dos gêneros mais representativos da $\mathrm{A} 00$ pode ser observada na figura 42.

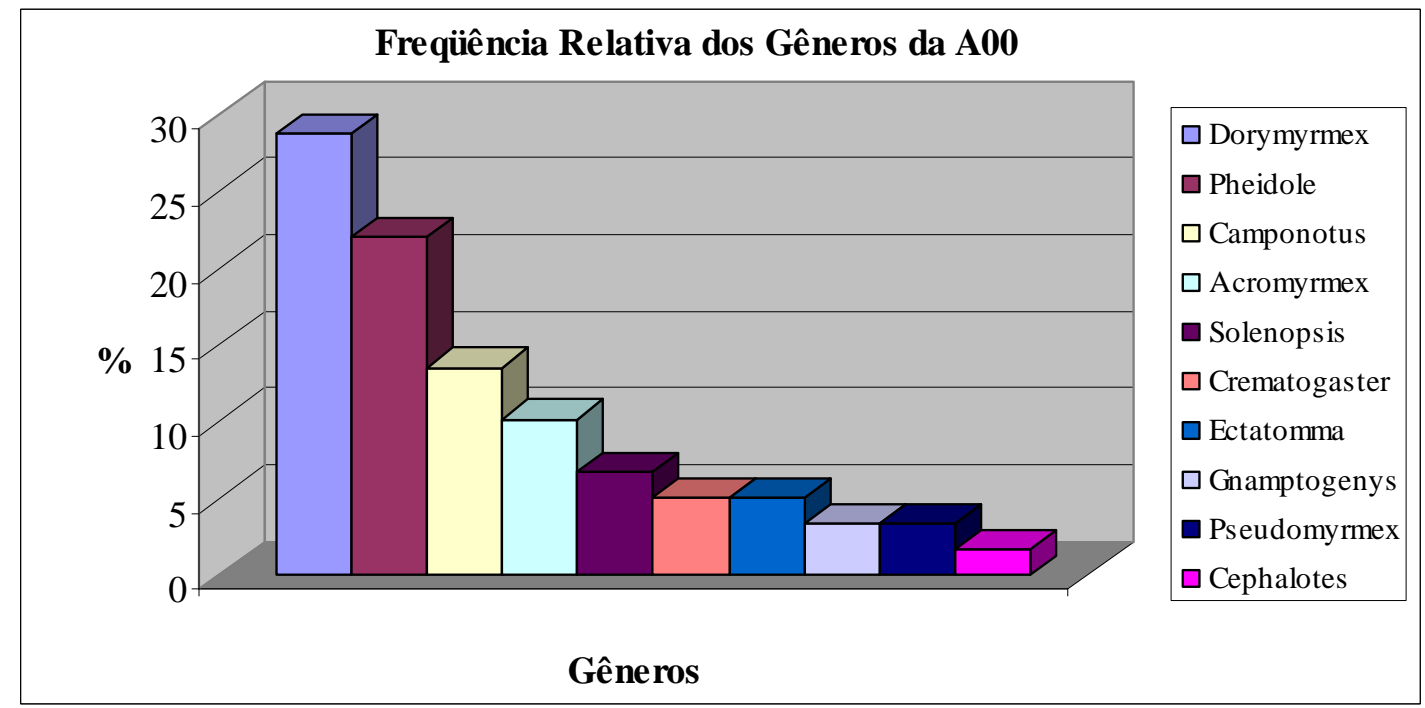

Figura 42 - Gráfico de freqüência relativa de todos os gêneros encontrados na Área de plantio 2000 (A00).

As medidas de riqueza e abundância de espécies constituem as análises mais comuns. Tais análises não indicam necessariamente uma resposta às 
modificações nos habitats, uma vez que as espécies menos adaptáveis às novas condições ambientais vão sendo substituídas por outras espécies de maneira similar. Assim, os índices de diversidade que incluem riqueza e igualdade de espécies, por exemplo, o Índice de Shannon ou o Índice de Simpson, acabam transmitindo "falsos" resultados, visto que perdem informações importantes como a identidade das espécies e a variação na sensibilidade a espécies raras e dominantes (MAGURRAN, 1988).

A análise de diversidade elaborada a partir da contagem da quantidade dos diferentes gêneros e espécies coletados possibilitou a elaboração de diagramas de abundância, facilitando a visualização das diferenças existentes entre as áreas estudadas. Os resultados obtidos com a análise de diversidade podem ser explicados pelos padrões de sucessão ecológica, já que a riqueza de espécies e os padrões de dominância das formigas possuem forte correlação com o tipo e a variedade da vegetação. Assim, a sensível redução da riqueza nas áreas de referência (AC1 e AC2) pode ser explicada pela aparente estabilidade do habitat mais preservado, e a maior riqueza na primeira área recuperada (A89) demonstra uma evolução intermediária na fase de recuperação.

A análise de freqüência relativa dos gêneros é interessante a partir do momento que é relacionada com outros resultados que devem ser coletados, concretizando o monitoramento ambiental. Desta maneira é possível comparar e visualizar diferenças na diversidade das diferentes áreas, ao longo do tempo, o que permite a caracterização da evolução dos habitats. Pela análise de freqüência dos gêneros é possível visualizar a alta freqüência relativa de uma ou poucas espécies, caracterizando a existência de dominância em praticamente todas as áreas de estudo, implicando a não completa recuperação dessas áreas, e sim em diferentes fases de evolução de sucessão.

\subsubsection{Análise de Afinidade e Similaridade}

Para entender como a fauna de formigas está organizada, optou-se por um teste de afinidade em que são gerados dados de similaridade e afinidade das espécies registradas nas áreas de coletas. Esta análise é um método proposto por ISTOCK e 
SCHEINER (1987) capaz de medir o padrão da composição da diversidade e da complexidade da paisagem, a partir de informações sobre espécies em diferentes habitats. Com o grau de afinidade entre as espécies, podemos definir as interações interespecíficas.

Para a análise de similaridade é utilizado o coeficiente de Jaccard, cuja fórmula é: $S i j=c /(a+b+c)$, sendo que $a$ e $b$ são as espécies encontradas somente em $i$ e $j$ respectivamente e $c$ o número de espécies comuns entre as localidades $i$ e $j$. As similaridades entre todas as áreas pareadas são computadas, e uma média para cada área é determinada. O coeficiente de similaridade varia de 0 e 1 , com 0 representando poucas ou nenhumas espécies em comum entre as áreas, e 1 representando alta similaridade entre as áreas (100\%). A afinidade entre as áreas é calculada a partir de medidas de distâncias relativas, ou seja, baseando-se no sentido e magnitude das diferenças entre cada par amostral (área) em relação ao todo (demais áreas).

Para esses cálculos, utilizou-se o Programa Estatístico de análise de afinidade "Affinity Analisys versão 4.3", possibilitando a observação da taxa de mudança que ocorre entre as áreas de coletas (Índice de Similaridade), medirem o padrão da composição da diversidade e complexidade da paisagem, usando informações sobre as espécies em um conjunto de subunidades ecológicas, de cada área (Índice de Afinidade), a velocidade de mudanças na composição específica da fauna ao longo de um gradiente (Diversidade Beta $(\beta)$ ) e exprimir o grau de complexidade da paisagem (Diversidade Mosaico). Os resultados da análise de afinidade podem ser observados na Tabela 5.4 e Tabela 5.5. 
Tabela 5.4 - Análise de Similaridade e de Afinidade das Áreas de Estudos.

\begin{tabular}{lccccccc}
\hline Áreas & $\begin{array}{c}\text { Similaridade } \\
\text { Média }\end{array}$ & $\begin{array}{c}\text { Desvio } \\
\text { Padrão } \\
\text { (Sim.) }\end{array}$ & $\begin{array}{c}\text { Afinidade } \\
\text { Média }\end{array}$ & $\begin{array}{c}\text { Desvio } \\
\text { Padrão } \\
\text { (Afin.) }\end{array}$ & $\begin{array}{c}\text { No de } \\
\text { Espécies }\end{array}$ & $\begin{array}{c}\text { No de } \\
\text { Espécies } \\
\text { Únicas }\end{array}$ & $\begin{array}{c}\text { Espécies } \\
\text { Comuns } \\
\text { entre as } \\
\text { Áreas }\end{array}$ \\
\hline AC & 0.2255 & 0.0214 & 0.0900 & 0.1245 & 25 & 6 & 9 \\
AC2 & 0.3340 & 0.1071 & 0.6100 & 0.3647 & 25 & 3 & 12.2 \\
A89 & 0.3253 & 0.0935 & 0.5800 & 0.3421 & 28 & 3 & 12.6 \\
A92 & 0.3780 & 0.1359 & 0.7500 & 0.2121 & 22 & 2 & 12.6 \\
A95 & 0.3775 & 0.1279 & 0.8100 & 0.1949 & 30 & 3 & 14.2 \\
A00 & 0.2608 & 0.0666 & 0.1600 & 0.3050 & 14 & 2 & 8.2 \\
\hline
\end{tabular}

Legenda: $\mathrm{AC} 1$ = Área Controle 1, AC2 = Áreas controle 2, A89 = Áreas com início da recuperação em 1989, A92 = Áreas com início da recuperação em 1992, A95 = Áreas com início da recuperação em 1995, A00 = Áreas com início da recuperação em 2000. SIM. = similaridade; Afin. = afinidade; № = número.

Tabela 5.5 - Sumário Estatístico das Análises.

\begin{tabular}{lcc}
\hline \multicolumn{1}{c}{ Sumário } & Média & Desvio Padrão \\
\hline Similaridade de Jaccard & 0.31684 & 0.06206 \\
(Diversidade $\boldsymbol{\beta}$ ) & & \\
Afinidade & 0.50000 & 0.30358 \\
No de Espécies por Áreas & 24.00 & 5.62 \\
№ de Espécies Únicas & 3.17 & 1.47 \\
№ de Espécies em Comum & 11.467 & 2.338 \\
Freqüência de Espécies & 2.48 & 1.51 \\
Diversidade de Mosaico $(\mathbf{m})$ & 4.83646 & - \\
$\mathbf{R}^{2 \star}$ & 0.97743 & - \\
\hline
\end{tabular}

Legenda: ${ }^{*} R^{2}=$ Porcentagem de variações explicadas pela amostra.

De acordo com os resultados obtidos da análise de afinidade e similaridade dos dados, não existe alta similaridade de espécies entre as áreas de coletas, apresentando um valor do coeficiente de similaridade de Jaccard, $S i j=0.31684$, este índice é também conhecido como diversidade $\beta$, que dá uma boa estimativa da diversidade entre os habitats. Apesar disto, a média do número de espécies em comum (11.467), foi maior que a média do número de espécies únicas (3.17). Todas as áreas de coletas apresentaram espécies únicas.

A Área Controle 1 (AC1) apresenta o maior número de espécies únicas, sendo que das 58 espécies de formigas registradas, seis foram encontradas exclusivamente nesta área, entre elas Crematogaster acuta, Hypoponera sp.01, Pachycondyla sp.01, Strumigenys sp.02, Trachymyrmex sp.02 e Trachymyrmex sp.03.. Para as demais áreas, foram registradas três espécies únicas para as áreas: Área controle 2 (AC2 - Linepithema sp.01, Pheidole sp.05, Strumigenys sp.03), Área 1989 (A89 - Anochetus sp.01, Ectatomma sp.01, Strumigenys sp.01) e Área 1995 (A95 - Acromyrmex sp.01, Solenopsis sp.03, Wasmannia sp.01); e duas espécies 
únicas para as áreas: Área 1992 (A92 - Leptothorax sp.01, Strumigenys sp.04) e Área 2000 (A00 - Cephalotes sp.01, Pheidole sp.08).

A área que apresentou maior riqueza de espécies em comum e maior afinidade média foi a Área 1995 (A95) com 14,2 espécies em comum e uma afinidade de 0.8100, seguida pelas áreas: Área 1992 (A92) com 12,6 espécies em comum e uma afinidade média de 0.7500 e a Área 1989 (A89) com 12,6 espécies em comum e uma afinidade de 0.5800 . Com relação à afinidade média de todas as áreas, os resultados apresentaram uma afinidade mediana (0.50000).

Após a Similaridade e Afinidades médias serem calculadas para cada área, é possível correlacionar estas medidas. A afinidade média é plotada contra a similaridade média, e a inclinação desta relação linear é computada através da fórmula $m=r S_{A} / S_{S}$, onde $r$ é o coeficiente de correlação, $S_{A}$ O desvio padrão das afinidades médias e $S_{S}$ o desvio padrão das similaridades médias. Esta inclinação mede a diversidade de padrões e a complexidade da paisagem. Para comunidades dentro de uma determinada paisagem esta medida é denominada Diversidade de Mosaico (m), e exprime o quanto uma comunidade pode ser complexa a partir da composição de suas espécies (ISTOCK; SCHEINER, 1987).

O resultado desta plotagem é uma correlação linear cuja inclinação mede a diversidade de padrões e a complexidade da paisagem (Figura 43).

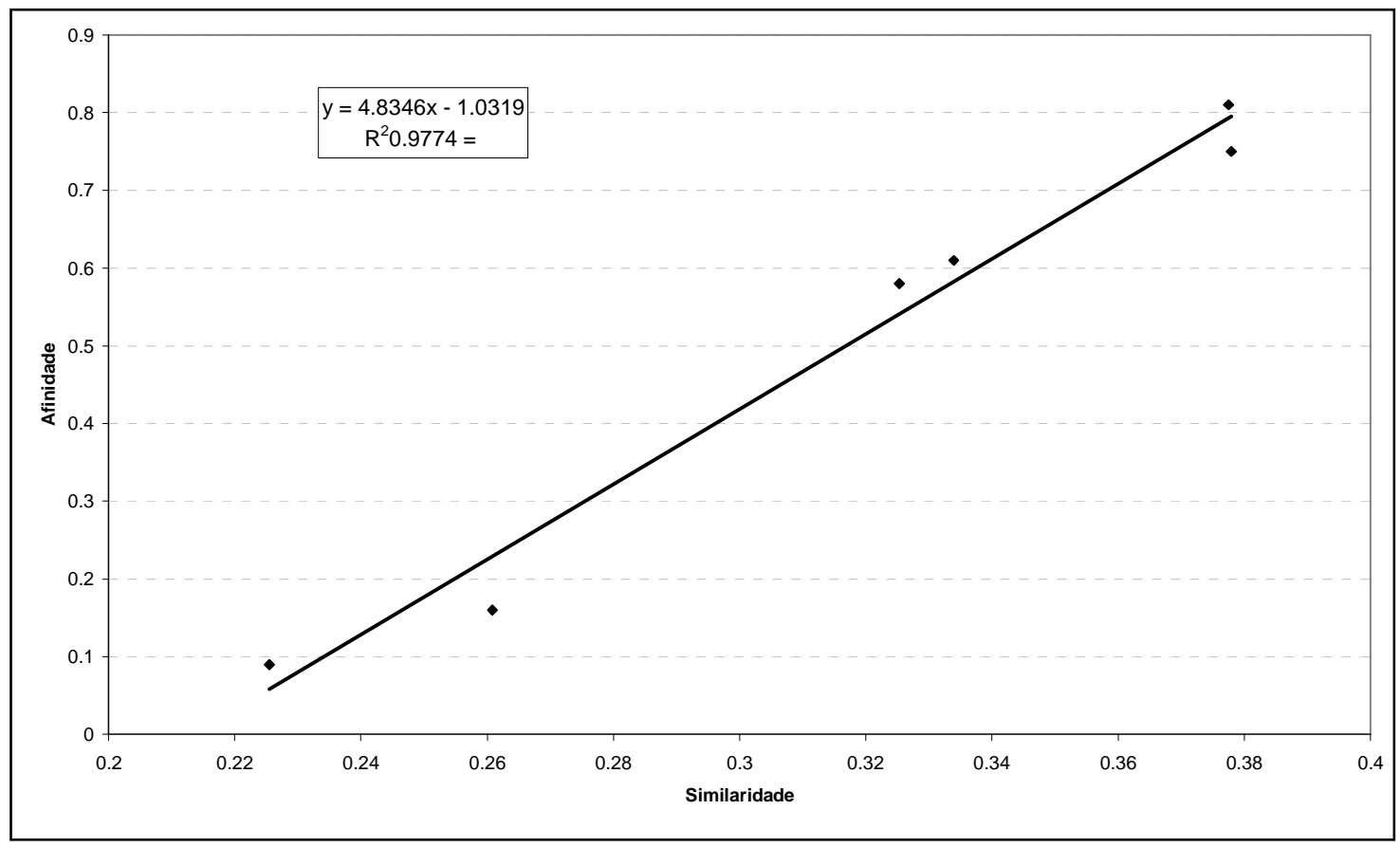

Figura 43 - Correlação linear entre similaridade e a afinidade. 
Observando a Figura 43, encontramos uma correlação positiva entre a Similaridade e a Afinidade das áreas de coleta. Esta correlação é estatisticamente significativa, visto que a quantidade de variações explicadas nesta análise é de $97,74 \%$.

As matrizes de Similaridade e Afinidade são calculadas para estimar, a partir de uma regressão linear, a Diversidade Mosaico $(m)$, que exprimi o grau de complexidade da paisagem. A Diversidade Mosaico $(\mathrm{m})$ apresentou um alto valor (média de 4.83646), tendo como base o que é proposto por SCHEINER (1992, apud ROCHA, 2004) que defini que locais com baixo índice de diversidade mosaico apresentam valores de " $m$ " em torno de 2.0 e as áreas com valores de "m" superiores a 3.0 são consideradas ambientes com uma alta variabilidade estrutural, (SCHEINER, 1992, apud FOWLER, 1996).

Os ambientes estudados evidenciaram alta complexidade ambiental que foi percebida através do baixo valor da média de similaridade de todas as áreas. A partir da análise de afinidade é possível estimar a complexidade do ambiente e, conseqüentemente, a diversidade de padrões que podem estar condicionando esta distribuição (FOWLER, 1999).

A baixa similaridade entre os pares de áreas amostradas é proporcional com a alta complexidade da composição de cada habitat, estimada pelo alto índice de diversidade de mosaico $(\mathrm{m})$, sendo que a avaliação dessa diversidade provou ser uma ferramenta importante, principalmente por revelar padrões complexos em escalas menores, ou seja, se ajustar a condições de heterogeneidade espacial que normalmente não são evidenciadas nas análises mais comuns (FOWLER, 1996).

Os testes de Afinidade e Similaridade definem dependência altamente significativa das espécies registradas nas áreas, determinando um alto grau de complexidade na organização da fauna de formigas. Este fato é confirmado pelo alto valor da diversidade mosaico ( $m=4.83$ ), sendo que $97,7 \%$ das variações das amostras são explicadas por este teste. 


\subsubsection{Análise de Agrupamento}

A análise de agrupamento (Cluster) é um método simples utilizado para estimar e visualizar a similaridade entre áreas relacionadas, e é realizada por meio de uma matriz de similaridade. A matriz e o dendograma de similaridade foi elaborada a partir do programa estatístico "NTSYSpc versão 2.02i". Utilizando como cálculo de distância o método da média dos grupos (UPMGA), sendo que neste método o agrupamento é feito com a média aritmética de seus elementos (ROMESBURG, 1984; apud CARNEIRO, 1999). Os agrupamentos foram gerados de uma matriz de similaridade utilizando o índice de Jaccard, com dados de presençaausência, a qual foi calculada comparando a similaridade das áreas em relação aos gêneros das formigas. A matriz de similaridade (Quadro 4) e o dendograma gerado pela análise de agrupamento (Figura 44) podem ser visualizados a seguir.

\begin{tabular}{||l|l|l|l|l|l|l|}
\hline Rows YCols & AC1 & AC2 & A89 & A92 & A95 & A00 \\
\hline ACl & 1.0000000 & & & & \\
\hline AC2 & 0.4285714 & 1.0000000 & & & \\
\hline A89 & 0.5454545 & 0.6190476 & 1.0000000 & & \\
\hline A92 & 0.4000000 & 0.4736842 & 0.4545455 & 1.0000000 & & \\
\hline A95 & 0.4000000 & 0.4736842 & 0.5238095 & 0.6250000 & 1.0000000 & \\
\hline A00 & 0.3888889 & 0.4705882 & 0.4500000 & 0.4375000 & 0.6428571 & 1.0000000 \\
\hline
\end{tabular}

Legenda: $\mathrm{AC} 1$ = Área Controle 1, AC2 = Áreas controle 2, A89 = Áreas com início da recuperação em 1989, A92 = Áreas com início da recuperação em 1992, A95 = Áreas com início da recuperação em 1995, A00 = Áreas com início da recuperação em 2000.

Quadro 4 - Matriz de similaridade dos gêneros registrados nas seis áreas de coleta. 


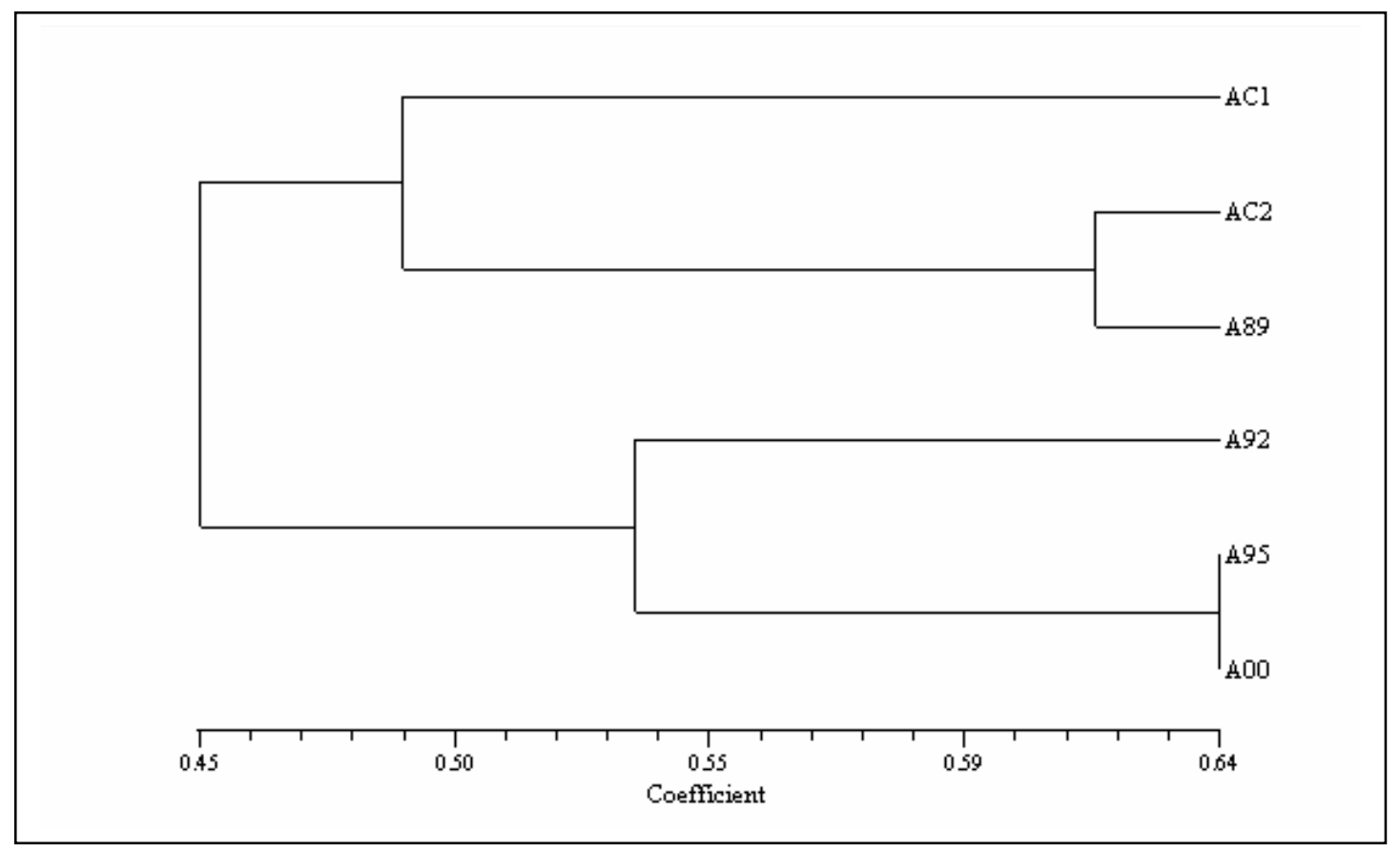

Legenda: $\mathrm{AC} 1$ = Área Controle 1, AC2 = Áreas controle 2, A89 = Áreas com início da recuperação em 1989, A92 = Áreas com início da recuperação em 1992, A95 = Áreas com início da recuperação em 1995, A00 = Áreas com início da recuperação em 2000

Figura 44 - Dendograma de similaridade das seis áreas de coletas.

A ordenação das localidades estudadas pelo método de agrupamento (UPGMA) permite visualizar que ao serem comparadas ao nível de gênero as áreas se dividem em dois grupos distintos: em estágios iniciais do processo de recuperação (A00, A95 e A92), e em estágios mais avançados de recuperação (A89, AC2 e AC1). As áreas de plantio A00 e A95 são as mais semelhantes entre si, apresentando um coeficiente de similaridade de 0.64;

\subsubsection{Análise de Grupos Funcionais}

Para a análise da estrutura funcional da comunidade de formigas em grupos funcionais realizaram-se extrapolações com base em dois trabalhos publicados: ANDERSEN (2000) e BROWN JR (2000), que classificaram as formigas da Austrália, e BESTELMEYER e WIENS (1996) que classificaram as formigas do Chaco argentino. 
5.1.4.1 Grupos funcionais caracterizados a partir dos dados dos grupos funcionais da Austrália.

A princípio, para a análise dos Grupos Funcionais, utilizou-se a classificação definida por ANDERSEN (2000) e BROWN JR (2000), sendo que todos os grupos existentes foram encontrados nas seis áreas de coletas desse estudo. Em relação à classificação das formigas com seus respectivos grupos funcionais, elaborou-se a Tabela 5.6.

Tabela 5.6 - Classificação dos grupos funcionais desenvolvidos por Andersen e Brown Jr (2000) para os respectivos gêneros de formigas registrados nas coletas $2 \mathrm{e}$ 3.

\begin{tabular}{lll}
\hline \multicolumn{1}{c}{ SUBFAMÍLIAS } & \multicolumn{1}{c}{ GÊNÊROS } & $\begin{array}{c}\text { GRUPOS } \\
\text { FUNCIONAIS }\end{array}$ \\
\hline Myrmicinae & Acromyrmex & TCS \\
Ponerinae & Anochetus & SP \\
Myrmicinae & Atta & TCS \\
Formicinae & Brachymyrmex & TCS \\
Formicinae & Camponotus & SC \\
Myrmicinae & Cephalotes & TCS \\
Myrmicinae & Crematogaster & GM \\
Myrmicinae & Cyphomyrmex & TCS \\
Dolichoderinae & Dorymyrmex & O/DD \\
Ponerinae & Ectatomma & O \\
Ponerinae & Gnamptogenys & TCS \\
Myrmicinae & Hylomyrma & TCS \\
Ponerinae & Hypoponera & C \\
Dorylinae & Labidus & TCS \\
Myrmicinae & Leptothorax & TCS \\
Dolichoderinae & Linepithema & DD \\
Ponerinae & Odontomachus & O \\
Ponerinae & Pachycondyla & SP \\
Formicinae & Paratrechina & O \\
Myrmicinae & Pheidole & GM \\
Pseudomyrmecinae & Pseudomyrmex & TCS \\
Myrmicinae & Solenopsis & C/TCS \\
Myrmicinae & Strumigenys & C \\
Myrmicinae & Trachymyrmex & TCS \\
Myrmicinae & Wasmannia & TCS \\
\hline Generalistas Myrmicinae; DD = Dominante Dolichoderinae; O = Oportunistas; C = & \\
Gam; SP = Predadoras Especialistas; TCS = Especialistas de Clima Tropical; e SC = & &
\end{tabular}

Os gêneros registrados nas áreas de estudo foram extrapolados de acordo com a classificação dos grupos funcionais estabelecidos por ANDERSEN (2000) e 
BROWN JR (2000), em relação à nomenclatura e as características de cada grupo funcional. Foram encontrados um total de sete grupos funcionais nos 25 gêneros registrados nas coletas 2 e 3 (Tabela 5.6).

A partir dessa classificação foi possível comparar os grupos funcionais encontrados em cada área de estudo. A Figura 45 representa a porcentagem de gêneros encontrados em cada grupo funcional para todas as áreas de estudo.

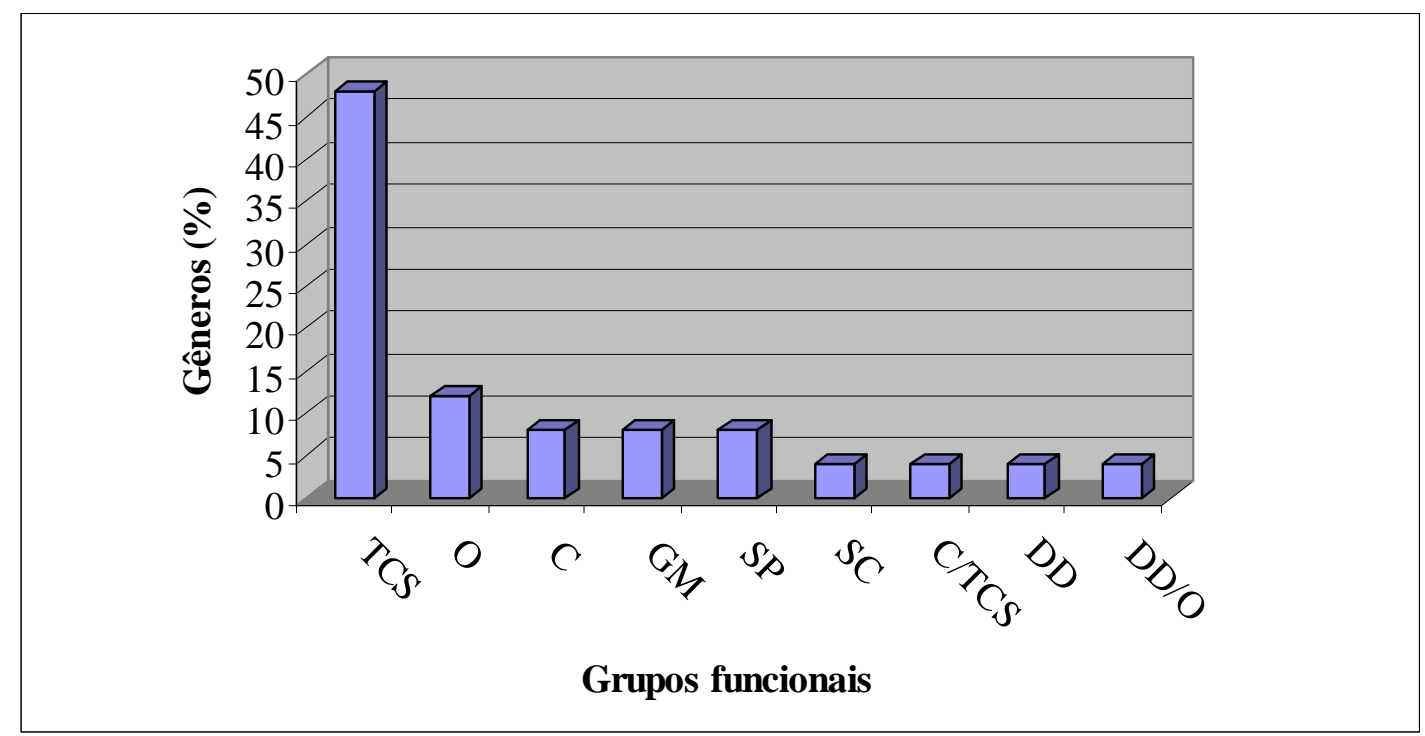

Legenda: $\mathrm{GM}=$ Generalistas Myrmicinae; $\mathrm{DD}=$ Dominante Dolichoderinae; $\mathrm{O}=$ Oportunistas; $\mathrm{C}=$ Espécies Crípticas; $\mathrm{SP}=$ Predadoras Especialistas; TCS = Especialistas de Clima Tropical; e SC = Subordinada Campotini.

Figura 45 - Porcentagem de gêneros registrados em cada um dos grupos funcionais de acordo com a classificação elaborada por Andersen e Brown Jr.(2000).

O grupo funcional Especialista de Clima Tropical (TCS) representa quase $50 \%$ dos 25 gêneros registrados em todas as áreas de estudo, seguido do grupo Oportunista (O) com 12\%, Criptica (C) (8\%), Generalista Myrmicinae (GM) e Predadora Especialista (SP) (com 8\% cada). O grupo "TCS" é composto por 12 gêneros; o grupo "O" com três gêneros, o grupo "GM", "C" e "SP" com dois gêneros cada e os grupos "SC", "DD", "O/DD" e "C/TCS" com um gênero cada. Todos os gêneros pertencentes a cada grupo funcional podem ser verificados na Tabela 5.6.

Para analisar cada área de coleta, formularam-se gráficos demonstrando a relação de número de gêneros aos diferentes grupos funcionais registrados, para cada uma das áreas de estudo (AC1, AC2, A89, A92, A95 e A00), para as coletas 2 e 3 . 


\section{Área Controle 1 (AC1)}

Foram registrados para essa área, 15 gêneros contendo 25 espécies diferentes, sendo o grupo "TCS" representado pelos gêneros: Trachymyrmex com três espécies, Brachymyrmex, Gnamptogenys, Hylomyrma, Pseudomyrmex e Wasmannia com uma espécie cada; o grupo "GM" representado pelos gêneros: Pheidole com quatro espécies, e pelo gênero Crematogaster com duas espécies. A área também apresenta gêneros pertencentes ao grupo funcional Subordinada Campotini (SC), contendo três espécies do gênero Camponotus; o grupo das Espécies Cripticas (C) representado pelos gêneros Hypoponera e Strumigenys, com uma espécie cada. Além dos grupos funcionais "O" e "SP", representados por um gênero cada: Odontomachus e Pachycondyla respectivamente, ambos com uma espécie. O gênero Dorymyrmex representado por uma espécie, pode ser classificado tanto no grupo "O" como no grupo "DD"; e o gênero Solenopsis, representado por três espécies podendo ser classificado tanto no grupo "C" como no grupo "TCS" (Figura 46).

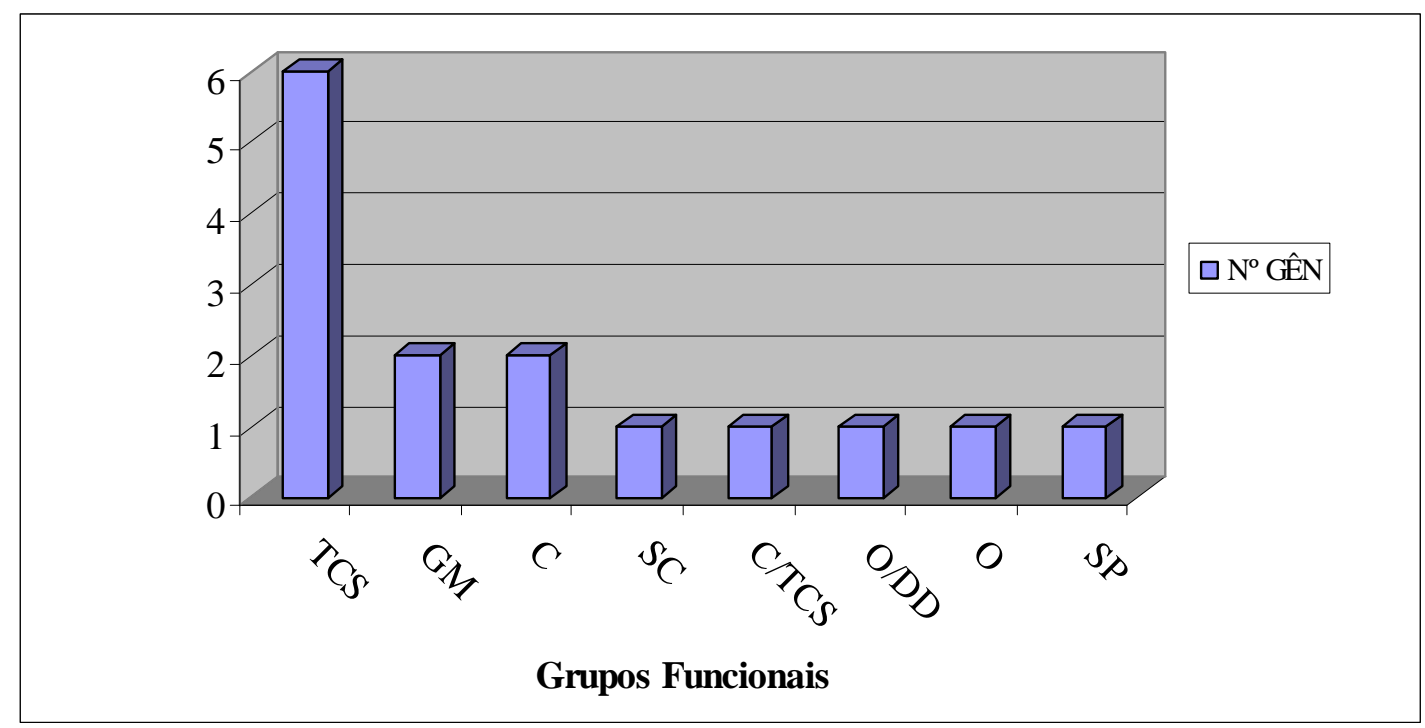

Legenda: $\mathrm{GM}=$ Generalistas Myrmicinae; $\mathrm{DD}=$ Dominante Dolichoderinae; $\mathrm{O}=$ Oportunistas; $\mathrm{C}=$ Espécies Crípticas; $\mathrm{SP}=$ Predadoras Especialistas; TCS = Especialistas de Clima Tropical; e SC = Subordinada Campotini.

Figura 46 - Gêneros registrados em cada grupo funcional na Área Controle 1 (AC1).

Observando as Figuras 46, podemos verificar que a AC1 é representada principalmente pelos gêneros pertencentes ao grupo funcional Especialista de Clima 
Tropical (TCS) constituindo cerca de $40 \%$ de todos os gêneros desta área; e pelo grupo funcional Generalista Myrmicinae (GM) e Crípticas (C) representando, cada uma, aproximadamente $13 \%$ dos gêneros registrados na área.

\section{Área Controle 2 (AC2)}

Foram registrados para esta área, 15 gêneros contendo 25 espécies diferentes, sendo o grupo "TSC" representado pelos gêneros Atta, Cephalotes, Gnamptogenys, Labidus e Trachymyrmex com uma espécie cada; o grupo "O" representado pelos gêneros Ectatomma, Odontomachus e Paratrechina com uma espécie cada; o grupo "GM" representado pelos gêneros Pheidole com seis espécies e Crematogaster com uma espécie. A área também apresenta uma espécie do gênero Strumigenys pertencente ao grupo funcional "C"; cinco espécies do gênero Campanotus, pertencente ao grupo funcional "SC"; e uma espécie do gênero Linepithema pertencente ao grupo funcional "DD". O gênero Dorymyrmex, com duas espécies, pode ser classificado tanto no grupo "O" como no grupo "DD"; e o gênero Solenopsis, com uma espécie, pode ser classificado tanto no grupo "C" como no grupo "TCS" (Figura 47).

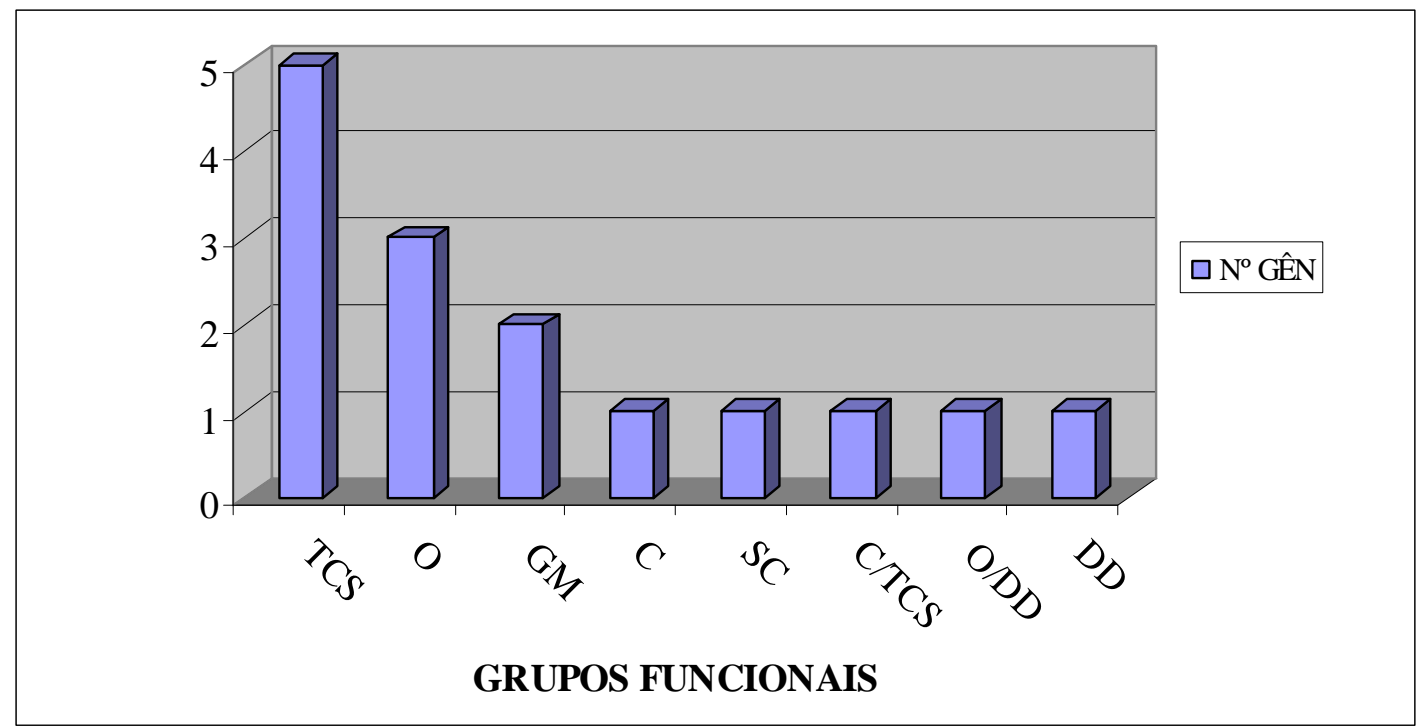

Legenda: $\mathrm{GM}=$ Generalistas Myrmicinae; $\mathrm{DD}=$ Dominante Dolichoderinae; $\mathrm{O}=$ Oportunistas; $\mathrm{C}=$ Espécies Crípticas; $\mathrm{SP}=$ Predadoras Especialistas; TCS = Especialistas de Clima Tropical; e SC = Subordinada Campotini.

Figura 47 - Gêneros registrados em cada grupo funcional na Área Controle 2 (AC2). 
Observando as Figuras 47, podemos verificar que cerca de 66\% da área é representada por gêneros pertencentes aos grupos funcionais: Especialistas de Clima Tropical (TCS) representando 33,3\%, Oportunistas (O) representando $20 \%$ e Generalista Myrmicinae (GM) representando $13 \%$ de todos os gêneros presentes na área.

\section{Área 1989 (A89)}

Foram registrados para essa área, 19 gêneros contendo 28 espécies diferentes, sendo o grupo funcional "TSC" representado pelos gêneros Wasmannia, Trachymyrmex, Pseudomyrmex, Labidus, Hylomyrma, Cephalotes, Brachymyrmex, Acromyrmex e Atta com uma espécie de cada gênero; o grupo funcional "O" representado pelos gêneros Ectatomma com duas espécies, Paratrechina e Odontomachus com uma espécie cada; o grupo "GM" está representado pelos gêneros Pheidole com duas espécies e Crematogaster com uma espécie. A área também apresenta gêneros pertencentes ao grupo "SC", contendo sete espécies do gênero Camponotus; além do grupo funcional "C" representado pelo gênero Strumigenys com uma espécie e do grupo "SP" representado pelo gênero Anochetus com uma espécie. O gênero Solenopsis, representado por duas espécies pode ser classificado tanto no grupo "C" como no grupo "TCS"; e o gênero Dorymyrmex, representado por uma única espécie, pode ser classificado tanto no grupo "O" como no grupo funcional "DD" (Figura 48). 


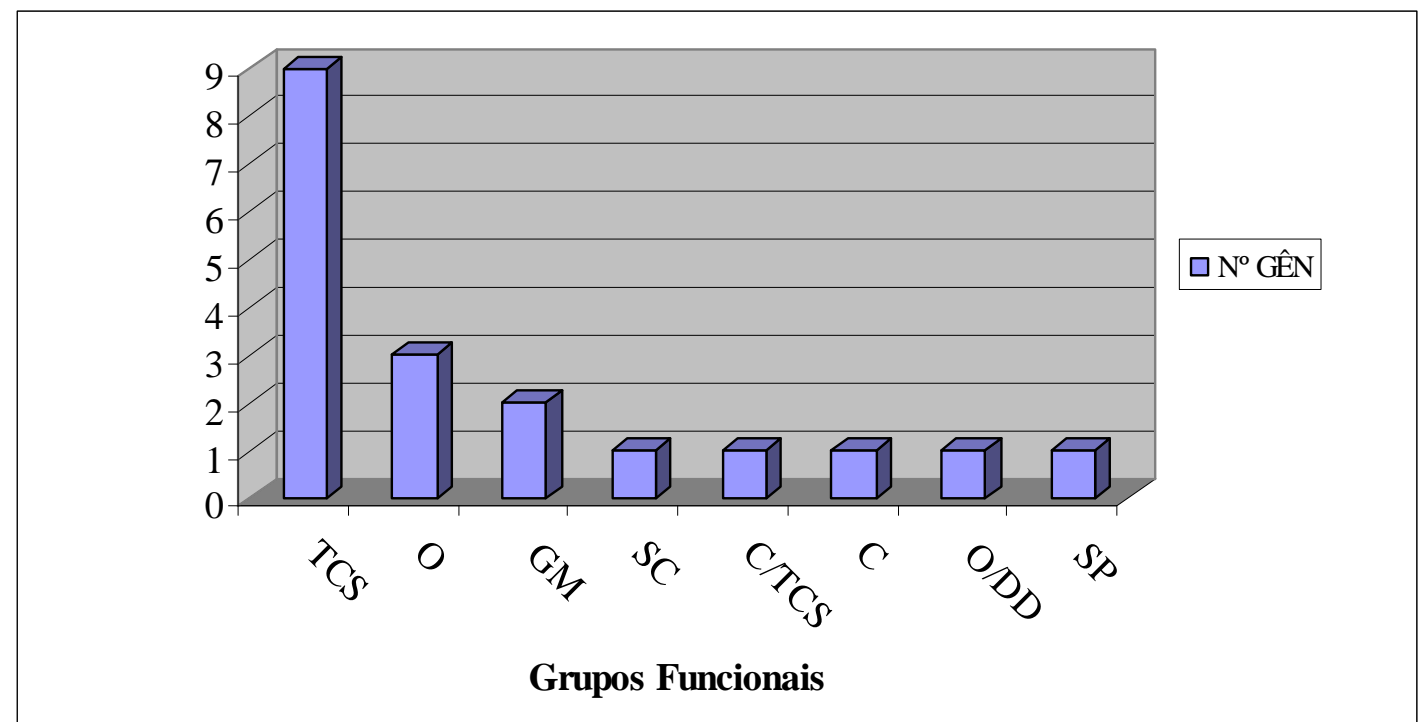

Legenda: $\mathrm{GM}=$ Generalistas Myrmicinae; $\mathrm{DD}=$ Dominante Dolichoderinae; $\mathrm{O}=$ Oportunistas; $\mathrm{C}=$ Espécies Crípticas; $\mathrm{SP}=$ Predadoras Especialistas; TCS = Especialistas de Clima Tropical; e SC = Subordinada Campotini.

Figura 48 - Gêneros registrados em cada grupo funcional na Área 1989 (A89).

Analisando a Figura 48, podemos observar que a área é representada com cerca de $73 \%$ por espécies pertencentes ao grupo funcional Especialista de Clima Tropical (TCS) representando $47 \%$ de todos os gêneros registrados na área, Oportunistas (O) com cerca de $16 \%$ de representatividade e Generalista Myrmicinae (GM) com cerca de $10 \%$ de representatividade.

\section{Área $1992($ A92)}

Foram registrados para esta área, 13 gêneros contendo 23 espécies diferentes, sendo o grupo "TCS" representado pelos gêneros Acromyrmex, Cyphomyrmex, Gnamptogenys, Leptothorax, Trachymyrmex e Wasmannia com uma espécie cada; o grupo "O" representado pelos gêneros Ectatomma e Paratrechina, ambos com uma espécie cada; o grupo "SC" representado pelo gênero Camponotus com seis espécies. A área também apresenta o grupo funcional "GM" representado por três espécies do gênero Pheidole; e o grupo "C" representado por uma espécie do gênero Strumigenys. O gênero Solenopsis representado por três espécies podendo ser classificado tanto no grupo "C" como no grupo "TCS"; e o gênero Dorymyrmex, representado por duas espécies, podendo ser classificado tanto no grupo "O" como no grupo "DD” (Figura 49). 


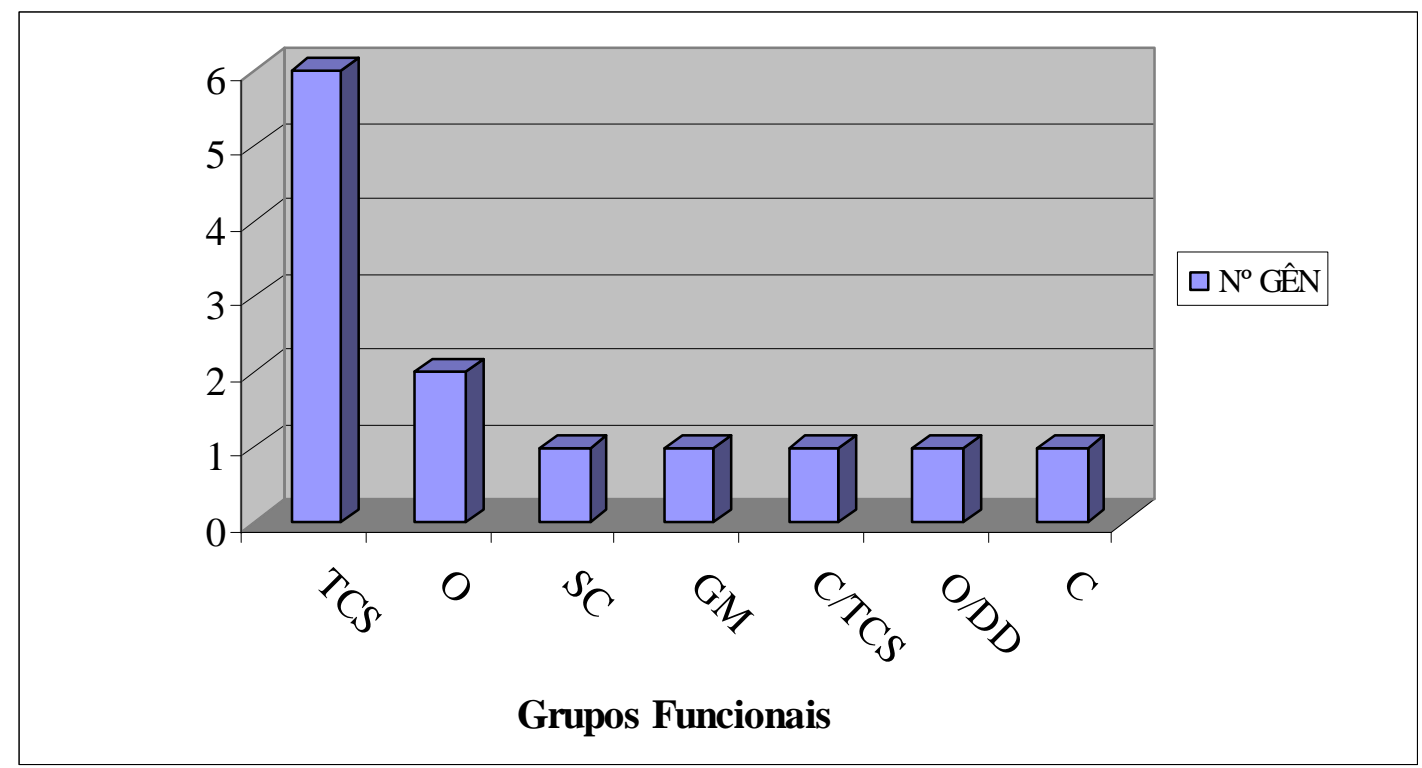

Legenda: $\mathrm{GM}=$ Generalistas Myrmicinae; $\mathrm{DD}=$ Dominante Dolichoderinae; $\mathrm{O}=$ Oportunistas; $\mathrm{C}=$ Espécies Crípticas; $\mathrm{SP}=$ Predadoras Especialistas; TCS = Especialistas de Clima Tropical; e SC = Subordinada Campotini.

Figura 49 - Gêneros registrados em cada grupo funcional na Área 1992 (A92).

Como pode ser visualizada na Figuras 49, a área é caracterizada em $61 \%$ pelos seguintes grupos funcionais: Especialista de Clima Tropical (TCS) e Oportunistas (O) com $46 \%$ e $15 \%$ respectivamente de representatividade. Já os demais grupos funcionais representam ao todo cerca de $38 \%$ de todos os grupos presentes na área.

\section{Área 1995 (A95)}

Foram registrados, para esta área, 13 gêneros contendo 30 espécies diferentes, sendo o grupo funcional "TSC" representado pelos gêneros Acromyrmex e Wasmannia com duas espécies cada, os gêneros Atta, Cyphomyrmex, Gnamptogenys e Pseudomyrmex com uma espécie cada. O grupo "O" representado pelos gêneros Ectatomma e Paratrechina com uma espécie cada; o grupo "GM" representado pelos gêneros Pheidole com quatro espécies, e pelo gênero Crematogaster com uma espécie. A área também apresenta nove espécies do gênero Camponotus pertencente ao grupo "SC"; além do gênero Solenopsis representado por quatro espécies, o qual pode ser classificado tanto no grupo "C" como no grupo "TCS"; e do gênero Dorymyrmex com duas espécies, o qual pode ser classificado tanto no grupo "O" como no grupo "DD" (Figura 50). 


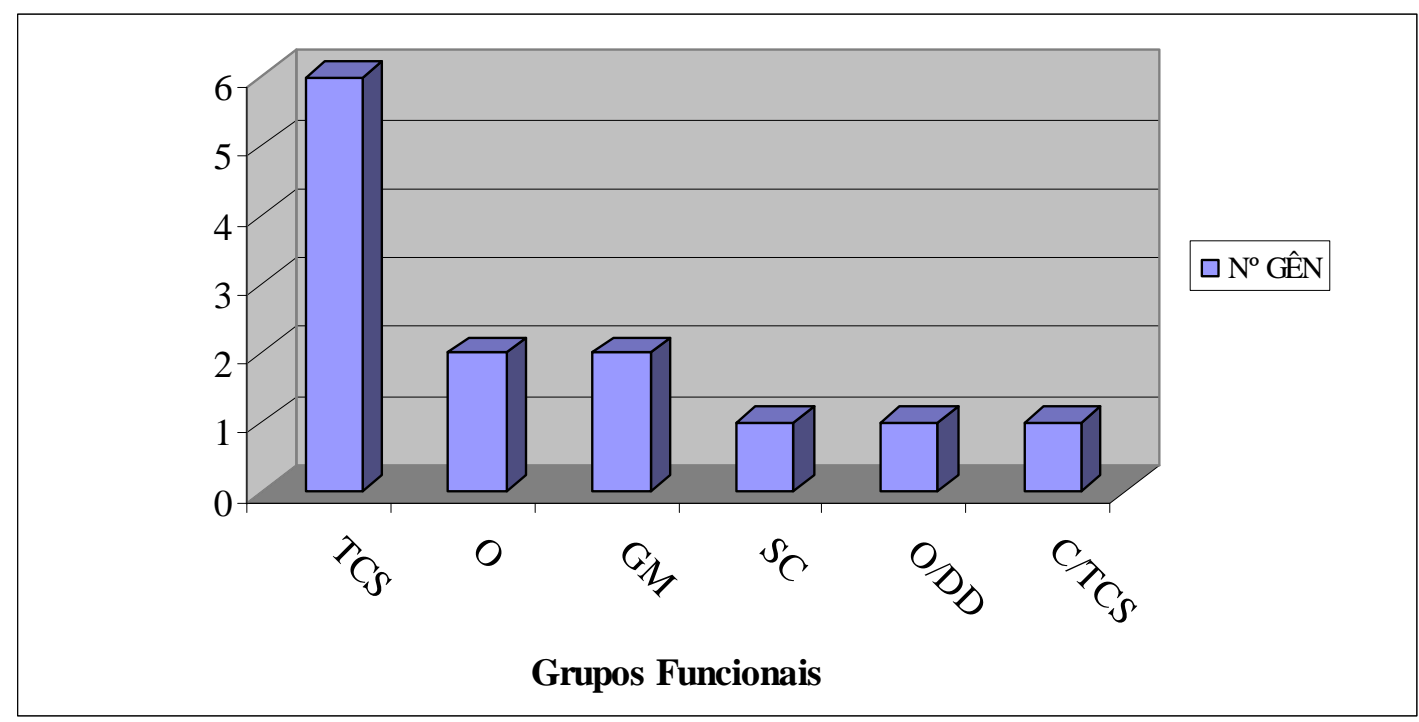

Legenda: $\mathrm{GM}=$ Generalistas Myrmicinae; $\mathrm{DD}=$ Dominante Dolichoderinae; $\mathrm{O}=$ Oportunistas; $\mathrm{C}=$ Espécies Crípticas; $\mathrm{SP}=$ Predadoras Especialistas; TCS = Especialistas de Clima Tropical; e SC = Subordinada Campotini.

Figura 50 - Gêneros registrados em cada grupo funcional na Área 1995 (A95).

Observando a Figura 50, podemos notar que esta área é representada por 76\% pelos seguintes grupos funcionais: Especialistas de Clima Tropical (TCS) com cerca de 46\%, Oportunistas (O) e Generalistas Myrmicinae (GM) com cerca de 15\% de representatividade cada. Já os demais grupos funcionais representam ao todo cerca de $23 \%$ de todos os grupos presentes na área.

\section{Área $2000(\mathrm{A00})$}

Foram registrados, para esta área, 10 gêneros contendo 14 espécies diferentes, sendo o grupo "TCS" representado pelos gêneros Acromyrmex, Cephalotes, Gnamptogenys e Pseudomyrmex com uma espécie cada; o grupo "GM" representado pelos gêneros Pheidole com duas espécies e Crematogaster com uma espécie. A área também apresenta uma espécie do gênero Camponotus pertencente ao grupo funcional "SC" e o grupo "O" representado pelo gênero Ectatomma. Além do gênero Solenopsis representado por duas espécies, que pode ser classificado tanto no grupo "C" como no grupo "TCS" e do gênero Dorymyrmex representado por uma espécie que pode ser classificada tanto no grupo "O" como no grupo "DD” (Figura 51). 


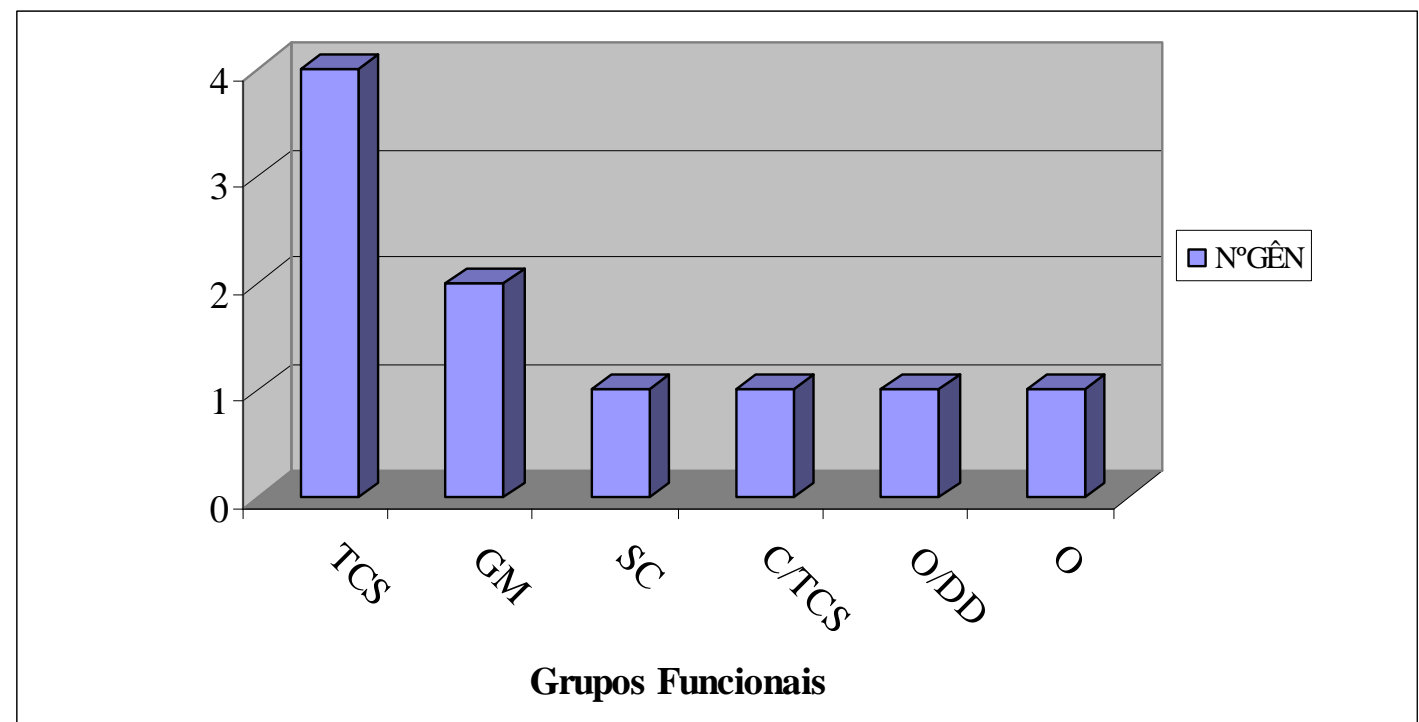

Legenda: $\mathrm{GM}=$ Generalistas Myrmicinae DD = Dominante Dolichoderinae; $\mathrm{O}=$ Oportunistas; $\mathrm{C}=$ Espécies Crípticas; $\mathrm{SP}=$ Predadoras Especialistas; TCS = Especialistas de Clima Tropical; e SC = Subordinada Campotini.

Figura 51 - Gêneros registrados em cada grupo funcional na Área 2000 (A00).

Como pode ser visualizado na Figura $51,60 \%$ da área é representado pelo grupo funcional Especialistas de Clima Tropical (TCS) com $40 \%$ de todos os gêneros, e pelo grupo Generalista Myrmicinae (GM) com 20\% de representatividade. Já os demais grupos funcionais representam ao todo $40 \%$ de todos os grupos presentes na área.

5.1.4.2 Grupos funcionais caracterizados a partir dos dados dos grupos funcionais do Chaco argentino

Outra extrapolação de Grupo Funcional utilizada foi a classificação desenvolvida por BESTELMEYER e WIENS (1996) para as formigas do Chaco argentino, sendo que dos 10 grupos funcionais existentes, foram registrados oito grupos nas seis áreas de coletas deste estudo. Em relação à classificação das formigas com seus respectivos grupos funcionais, elaborou-se a Tabela 5.7. 
Tabela 5.7 - Classificação dos grupos funcionais desenvolvidos por Bestelmeyer e Wiens (1996) para os respectivos gêneros de formigas registrados nas coletas 2 e 3 .

\begin{tabular}{llc}
\hline \multicolumn{1}{c}{ SUBFAMÍLIAS } & \multicolumn{1}{c}{ GÉNEROS } & $\begin{array}{c}\text { GRUPOS } \\
\text { FUNCIONAIS }\end{array}$ \\
\hline Myrmicinae & Acromyrmex & $\mathrm{At}$ \\
Ponerinae & Anochetus & $\mathrm{Cr}$ \\
Myrmicinae & Atta & $\mathrm{At}$ \\
Formicinae & Brachymyrmex & $\mathrm{Cr}$ \\
Formicinae & Camponotus & $\mathrm{Ca}$ \\
Myrmicinae & Cephalotes & $?$ \\
Myrmicinae & Crematogaster & $\mathrm{Gm}$ \\
Myrmicinae & Cyphomyrmex & $\mathrm{At}$ \\
Dolichoderinae & Dorymyrmex & $\mathrm{Op}$ \\
Ponerinae & Ectatomma & $\mathrm{Op}$ \\
Ponerinae & Gnamptogenys & $\mathrm{Op}$ \\
Myrmicinae & Hylomyrma & $?$ \\
Ponerinae & Hypoponera & $\mathrm{Cr}$ \\
Dorylinae & Labidus & $\mathrm{Ec}$ \\
Myrmicinae & Leptothorax & $\mathrm{Cr}$ \\
Dolichoderinae & Linepithema & $?$ \\
Ponerinae & Odontomachus & $\mathrm{Pr}$ \\
Ponerinae & Pachycondyla & $\mathrm{Pr}$ \\
Formicinae & Paratrechina & $?$ \\
Myrmicinae & Pheidole & $\mathrm{Gm} / \mathrm{Cr}$ \\
Pseudomyrmecinae & Pseudomyrmex & $\mathrm{Ab}$ \\
Myrmicinae & Solenopsis & $\mathrm{Gm} / \mathrm{Cr}$ \\
Myrmicinae & Strumigenys & $?$ \\
Myrmicinae & Trachymyrmex & $\mathrm{At}$ \\
Myrmicinae & Wasmannia & $\mathrm{Cr}$ \\
\hline
\end{tabular}

Legenda: $\mathrm{Pr}=$ Predadoras Especialistas; $\mathrm{Ca}=$ Camponotus; $\mathrm{Gm}=$ Generalistas Myrmicines; $\mathrm{Op}=$ Oportunistas; $\mathrm{DD}=$ Dominantes Dolichoderinae; $\mathrm{Cr}=$ Criptica; $\mathrm{At}=$ Attini; $\mathrm{Ec}=$ Ecitonini; $\mathrm{Ab}=$ Arboreal; ? = grupo não definido

Os gêneros registrados nas áreas de estudo foram classificados de acordo com a classificação dos grupos funcionais estabelecidos por BESTELMEYER e WIENS (1996), em relação à nomenclatura e as características de cada grupo funcional.

A partir dessa classificação foi possível comparar os grupos funcionais encontrados em cada área de estudo. A Figura 52 representa a porcentagem de gêneros encontrados em cada grupo funcional para todas as áreas deste estudo (coletas 2 e 3 ). 


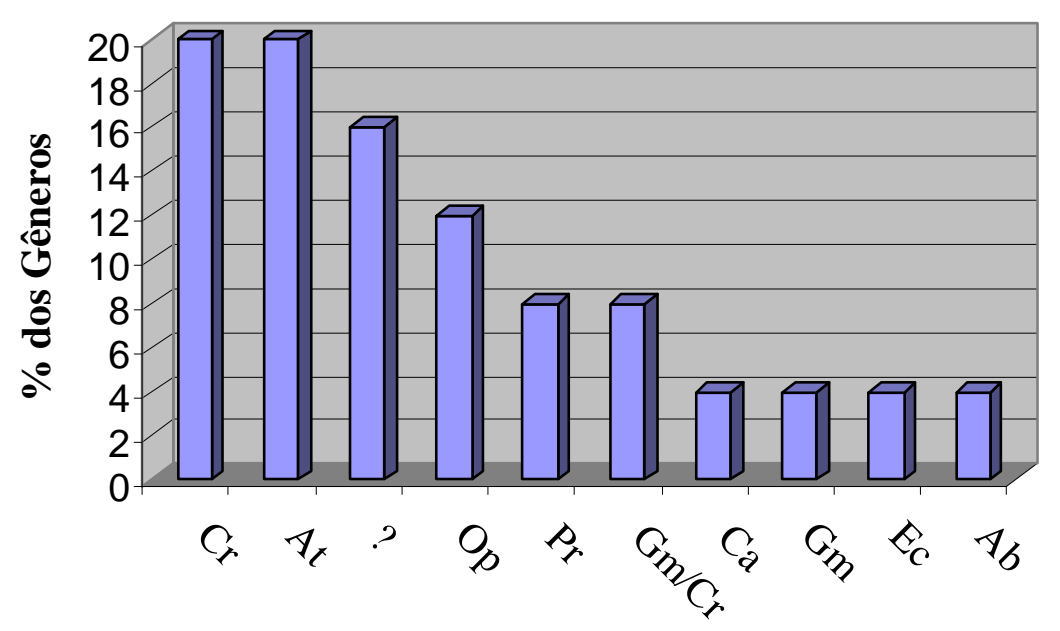

Grupos Funciomais

Legenda: $\mathrm{Pr}=$ Predadoras Especialistas; $\mathrm{Ca}=$ Camponotus; $\mathrm{Gm}=$ Generalistas Myrmicines; $\mathrm{Op}=$ Oportunistas; $\mathrm{DD}=$ Dominantes Dolichoderinae; $\mathrm{Cr}=$ Criptica; At = Attini; $\mathrm{Ec}=$ Ecitonini; $\mathrm{Ab}=$ Arboreal; ? = grupo não definido.

Figura 52 - Porcentagem de gêneros registrados em cada um dos grupos funcionais de acordo com a classificação estabelecida por Bestelmeyer e Wiens (1996).

O grupo funcional das Espécies Cripticas ( $\mathrm{Cr}$ ) e Attini (At) representa $40 \%$ dos 25 gêneros registrados em todas as áreas de estudo, seguido do grupo Oportunista (O) com 12\%, Predadoras Especialistas ( $\operatorname{Pr}$ ) $(8 \%)$, pelos gêneros que podem ser classificados tanto como Generalistas Myrmicines ou Cripticas ( $\mathrm{Gm} / \mathrm{Cr}$ ) $(8 \%)$, e Camponotus (Ca), Generalistas Myrmicines (Gm), Ecitinini (Ec) e Arboral (Ab) com $4 \%$ cada de representatividade. O grupo "Cr" é composto por cinco gêneros; as "At" com quatro gêneros, o grupo "Op" com três gêneros, o grupo "Pr" e "Gm/Cr" com dois gêneros, e as "Ca", "Gm", "Ec" e "Ab" com um gênero cada. Sendo que, 16\% dos gêneros não foram classificados em nenhum dos grupos funcionais. Todos os gêneros pertencentes a cada grupo funcional podem ser verificados na Tabela 5.7.

Para analisar cada área de coleta, formularam-se gráficos demonstrando a relação de número de gêneros aos diferentes grupos funcionais registrados, para cada uma das áreas de estudo (AC1, AC2, A89, A92, A95 e A00), para as coletas 2 e 3 . 


\section{Área Controle 1 (AC1)}

Foram registrados para esta área, 15 gêneros contendo 25 espécies diferentes, sendo o grupo "Cr" representado pelos gêneros: Brachymyrmex com uma espécie, Hypoponera com uma espécie, e Wasmannia com uma espécie; o gênero Pheidole com quatro espécies e o gênero Solenopsis com três espécies que podem ser classificados tanto no grupo "Gm" como no grupo "Cr"; o grupo "Op" representado pelos gêneros Dorymyrmex e Gnamptogenys ambos contendo uma espécie cada; o grupo "Pr" representado pelos gêneros Odontomachus e Pachycondyla ambos contendo uma espécie cada. A área também apresenta o gênero pertencente ao grupo funcional "Ca", contendo três espécies do gênero Camponotus; além dos grupos funcionais "At" representados pelo gênero Trachymyrmex com três espécies, o grupo "Gm" representado pelo gênero Crematogaster com duas espécies, e o grupo "Ab" representado pelo gênero Pseudomyrmex com uma espécie. Os gêneros Hylomyrma e Strumigenys, ambos com uma espécie cada, não foram classificados em nenhum dos grupos funcionais (Figura 53).

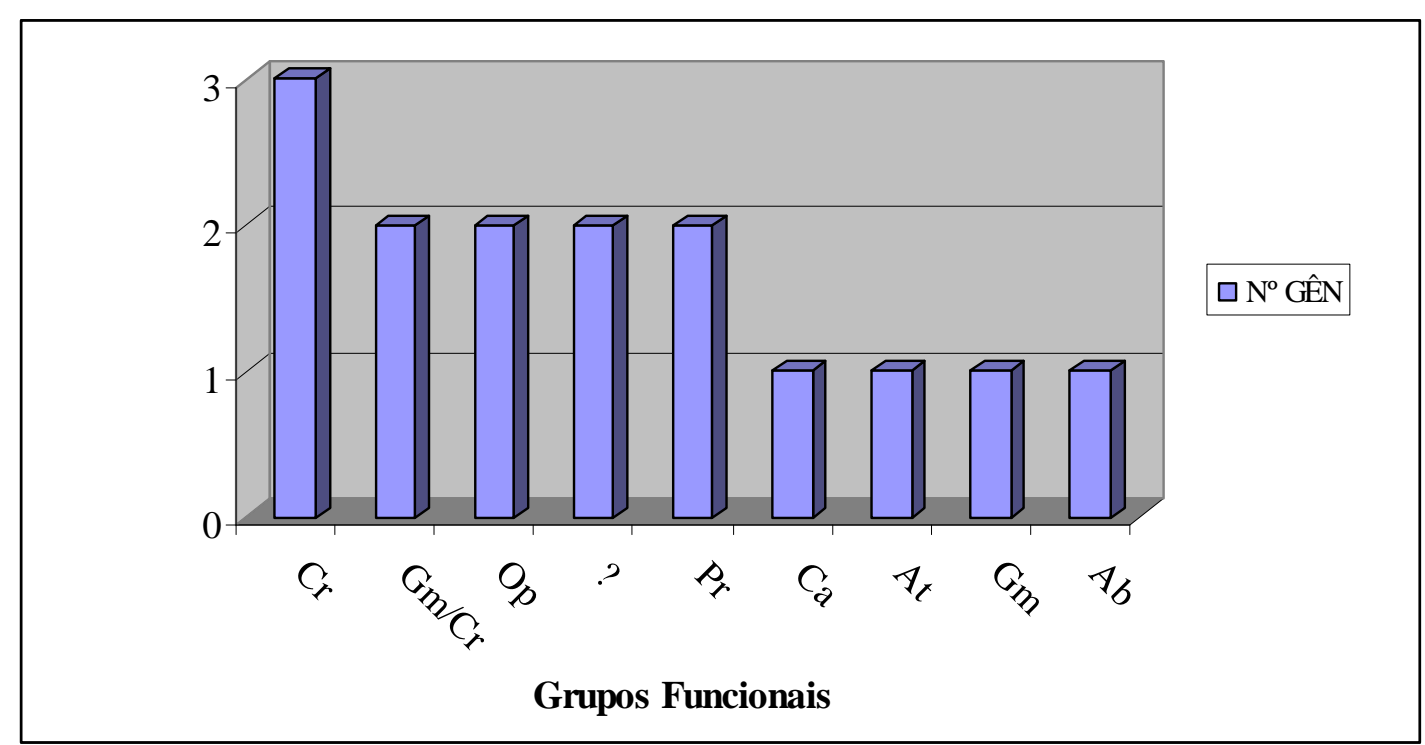

Legenda: $\mathrm{Pr}=$ Predadoras Especialistas; $\mathrm{Ca}=$ Camponotus; $\mathrm{Gm}=$ Generalistas Myrmicines; $\mathrm{Op}=$ Oportunistas; $\mathrm{DD}=$ Dominantes Dolichoderinae; $\mathrm{Cr}=$ Criptica; At $=$ Attini; $\mathrm{Ec}=$ Ecitonini; $\mathrm{Ab}=$ Arboreal; ? = grupo não definido.

Figura 53 - Gêneros registrados em cada grupo funcional na Área Controle 1 (AC1).

Observando as Figuras 53, verifica-se que a AC1 é representada principalmente pelos gêneros pertencentes ao grupo funcional das espécies 
Cripticas ( $\mathrm{Cr}$ ) constituindo cerca de $20 \%$ de todos os gêneros desta área e pelo grupo funcional dos gêneros que podem ser classificados tanto como Generalistas como Crípticas $(\mathrm{Gm} / \mathrm{Cr})$, o grupo Oportunista (Op), e o grupo Predadoras (Pr) representando cada um aproximadamente $13 \%$ dos gêneros registrados na área. Já os demais grupos funcionais ( $\mathrm{Ca}, \mathrm{At}, \mathrm{Gm}$, e $\mathrm{Ab}$ ) representam ao todo $28 \%$ de todos os grupos presentes na área.

\section{Área Controle 2 (AC2)}

Foram registrados para esta área, 15 gêneros contendo 25 espécies diferentes, sendo o grupo "Op" representados pelos gêneros Dorymyrmex contendo duas espécies, Ectatomma e Gnamptogenys com uma espécie de cada; os gêneros Pheidole com seis espécies e o gênero Solenopsis com uma espécie podendo ser classificados tanto como "Gm" como "Cr"; o grupo "At" representado pelo gênero Atta e Trachymyrmex, contendo uma espécie de cada. A área também apresenta cinco espécies do gênero Camponotus pertencente ao grupo funcional das " $\mathrm{Ca}$ "; o grupo "Gm" representado pelo gênero Crematogaster, o grupo "Ec" representado pelo gênero Labidus, e o grupo "Pr" representado pelo gênero Odontomachus todos contendo uma espécie cada. Os gêneros Cephalotes, Linepthema, Paratrechina e Strumigenys, com uma espécie de cada, não foram classificados em nenhum dos grupos funcionais (Figura 54). 


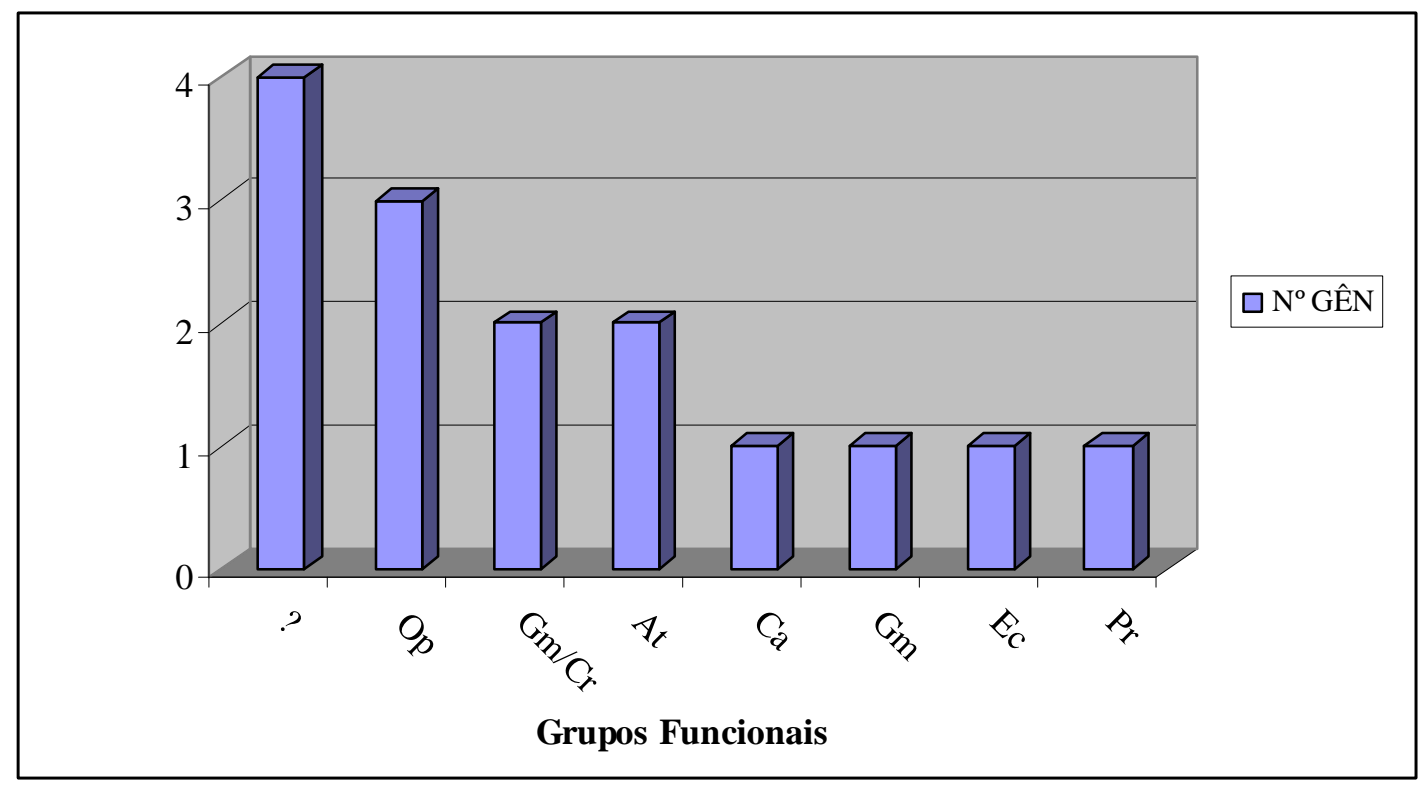

Legenda: $\mathrm{Pr}=$ Predadoras Especialistas; $\mathrm{Ca}=$ Camponotus; $\mathrm{Gm}=$ Generalistas Myrmicines; $\mathrm{Op}=$ Oportunistas; $\mathrm{DD}=$ Dominantes Dolichoderinae; $\mathrm{Cr}=$ Criptica; At $=$ Attini; $\mathrm{Ec}=$ Ecitonini; $\mathrm{Ab}=$ Arboreal; ? = grupo não definido.

Figura 54 - Gêneros registrados em cada grupo funcional na Área Controle 2 (AC2).

Observando as Figuras 54, verifica-se que cerca de $46 \%$ da área é representada por gêneros pertencentes ao grupo funcional Oportunista (O) representando 20\%, Attini (At) representando cerca de $13 \%$ e pelos gêneros que podem ser classificados tanto como Generalista como Criptica (Gm/Cr) representando cerca de $13 \%$. Já os demais grupos funcionais representam ao todo cerca de $26 \%$ de todos os grupos presentes na área. Além disto, $26 \%$ dos gêneros não foram classificados em grupos funcionais.

\section{Área 1989 (A89)}

Foram registrados para esta área, 19 gêneros contendo 28 espécies diferentes, sendo o grupo funcional "Cr" representado pelos gêneros Wasmannia, Brachymyrmex e Anochetus com uma espécie de cada gênero; o grupo funcional "At" representado pelos gêneros Trachymyrmex, Atta e Acromyrmex com uma espécie cada. Os gêneros Solenopsis e Pheidole, ambos com duas espécies cada podendo ser classificados tanto como "Gm" como "Cr"; o grupo das "Op" representado pelo gênero Ectatomma, com duas espécies, e pelo gênero Dorymyrmex contendo uma espécie. A área também apresenta o gênero pertencente ao grupo "SC", contendo sete espécies do gênero Camponotus; além 
dos grupos funcionais "Ab" representado pelo gênero Pseudomyrmex com uma espécie; o grupo "Pr" representado pelo gênero Odontomachus com uma espécie; o grupo "Ec" representado pelo gênero Labidus com uma espécie; e o grupo "Gm", representado pelo gênero Crematogaster com uma espécie. Os gêneros Strumigenys, Paratrechina, Hylomyrma e Cephalotes não foram classificados em nenhum dos grupos funcionais (Figura 55 ).

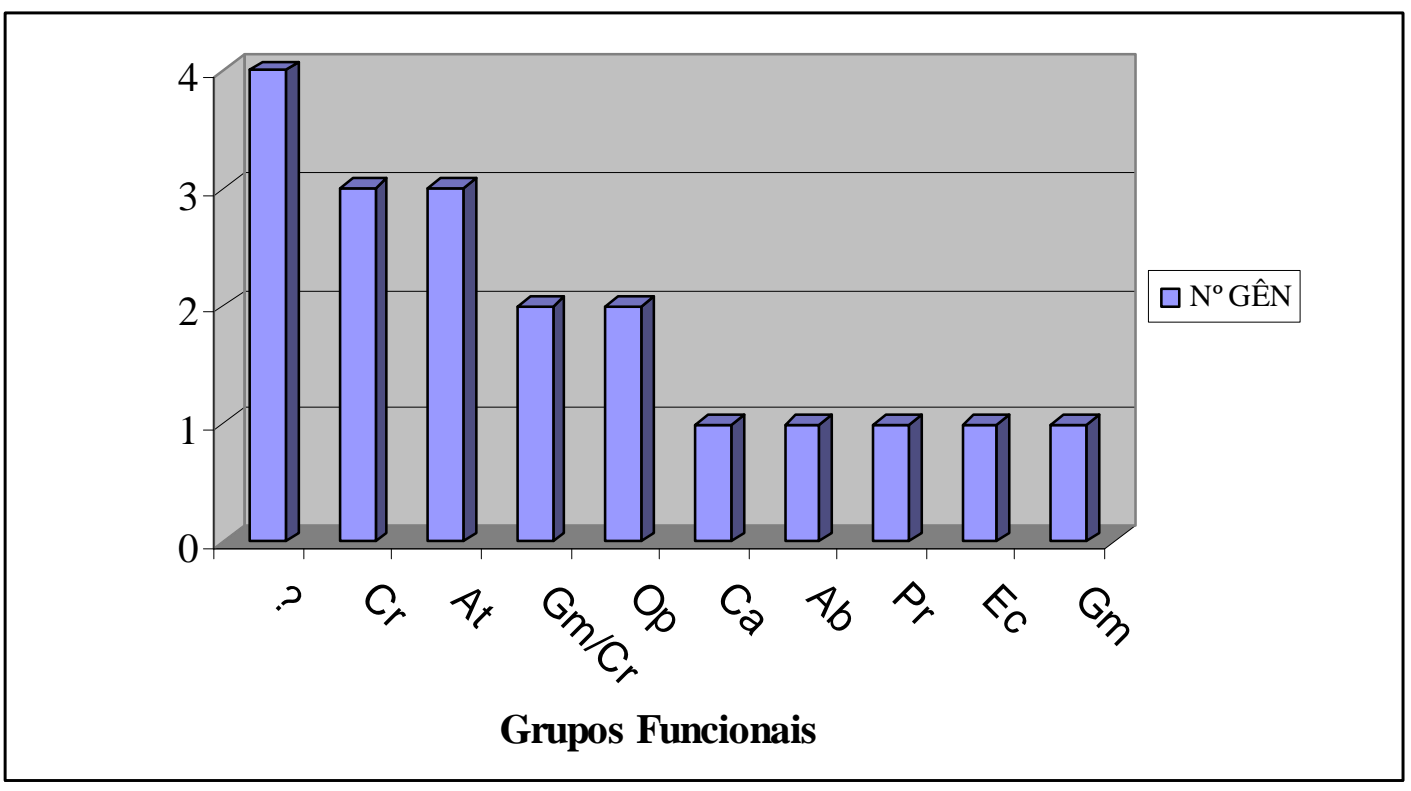

Legenda: $\mathrm{Pr}=$ Predadoras Especialistas; $\mathrm{Ca}=$ Camponotus; $\mathrm{Gm}=$ Generalistas Myrmicines; $\mathrm{Op}=$ Oportunistas; $\mathrm{DD}=$ Dominantes Dolichoderinae; $\mathrm{Cr}=$ Criptica; At = Attini; Ec = Ecitonini; $\mathrm{Ab}=$ Arboreal; ? = grupo não definido.

Figura 55 - Gêneros registrados em cada grupo funcional na Área 1989 (A89).

Segundo visualizado na Figura 55, a área é representada em cerca de 53\% por espécies pertencentes aos grupos funcionais das Espécies Crípticas $(\mathrm{Cr})$ e pelo grupo Attini (At) representando cerca de 16\% cada, o grupo Oportunista (Op) e dos gêneros que podem ser classificados tanto no grupo das Generalistas como no grupo das Espécies Cripticas $(\mathrm{Gm} / \mathrm{Cr}$ ) representado cerca de $10,5 \%$ cada. Já os demais grupos funcionais representam ao todo cerca de $26 \%$ de todos os grupos presentes na área. Além disto, cerca $20 \%$ dos gêneros não foram classificados em nenhum dos grupos funcionais. 


\section{Área 1992 (A92)}

Foram registrados para esta área, 13 gêneros contendo 23 espécies diferentes, sendo o grupo "Op" representado pelos gêneros Dorymyrmex com duas espécies, Ectatomma e Dorymyrmex com uma espécie de cada; o grupo "At" representado pelos gêneros Acromyrmex, Cyphomyrmex e Trachymyrmex com uma espécie de cada; o grupo "Cr" representado pelos gêneros Leptothorax e Wasmannia com uma espécie de cada. Os gêneros Pheidole e Solenopsis ambos com três espécies cada podendo ser classificados tanto no grupo Generalista como no grupo das Espécies Cripticas (Gm/Cr); e o grupo "Ca" representado pelo gênero Camponotus com seis espécies. Os gêneros Paratrechina e Strumigenys, não foram classificados em nenhum dos grupos funcionais (Figura 56).

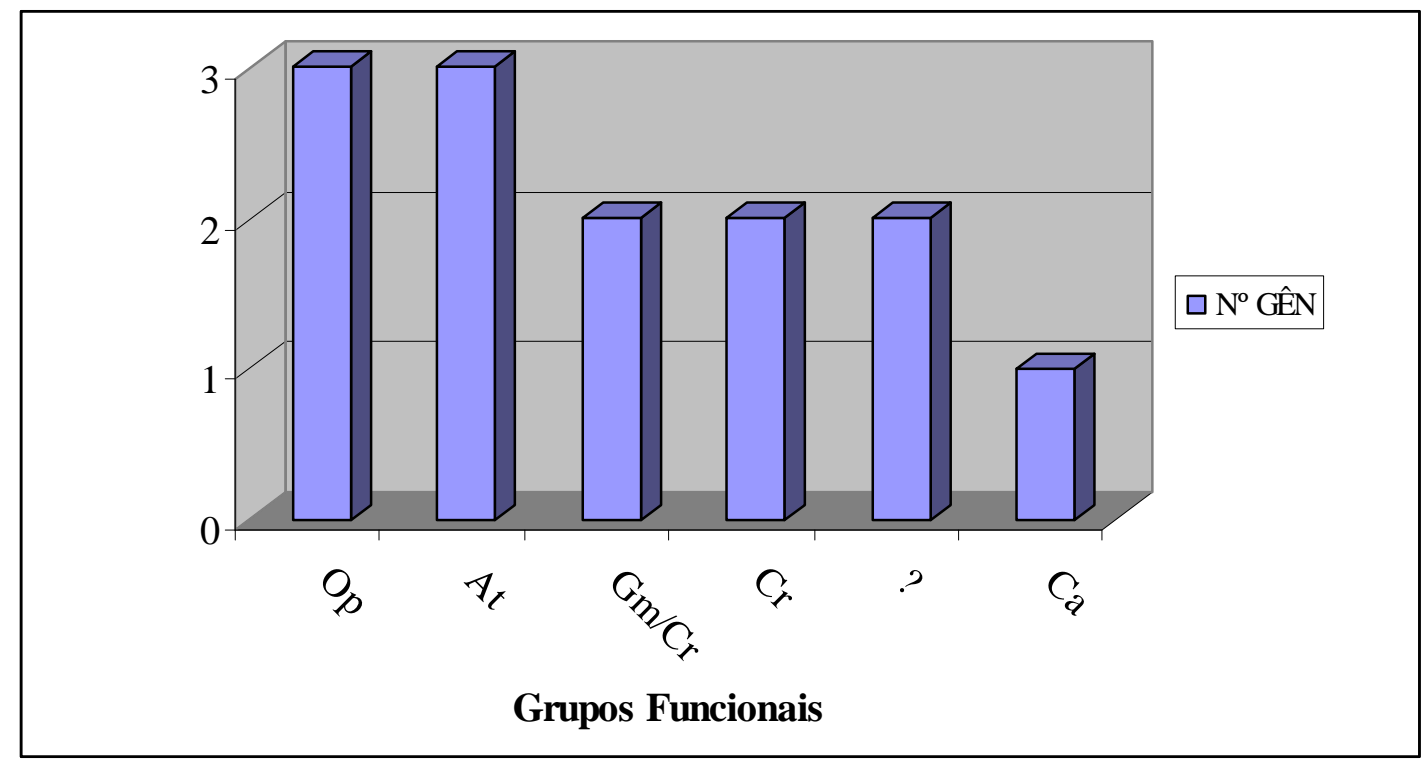

Legenda: $\operatorname{Pr}=$ Predadoras Especialistas; $\mathrm{Ca}=$ Camponotus; $\mathrm{Gm}=$ Generalistas Myrmicines; $\mathrm{Op}=$ Oportunistas; $\mathrm{DD}=$ Dominantes Dolichoderinae; $\mathrm{Cr}=$ Criptica; At $=$ Attini; $\mathrm{Ec}=$ Ecitonini; $\mathrm{Ab}=$ Arboreal; ? = grupo não definido.

Figura 56 - Gêneros registrados em cada grupo funcional na Área 1992 (A92).

Como pode ser visualizada na Figura 56, a área é caracterizada em $46 \%$ pelos seguintes grupos funcionais: o grupo Oportunistas (Op) e o grupo Attini (At) com cerca de $23 \%$ de representatividade cada. Já os demais grupos funcionais representam ao todo cerca de 38\%: "Gm/Cr" com cerca de 15\%, "Cr" com cerca de $15 \%$ e "Ca" com cerca de 7,5\% de representatividade de todos os grupos presentes 
na área. Além disto, cerca $15 \%$ dos gêneros não foram classificados em nenhum dos grupos funcionais.

\section{Área 1995 (A95)}

Foram registrados, para esta área, 13 gêneros contendo 30 espécies diferentes, sendo o grupo funcional "At" representado pelos gêneros Acromyrmex com duas espécies, Atta e Cyphomyrmex com uma espécie de cada; o grupo "Op" representado pelos gêneros Dorymyrmex com duas espécies, e pelos gêneros Ectatomma e Gnamptogenys com uma espécie de cada. Os gêneros Pheidole e Solenopsis, ambos com quatro espécies de cada podendo ser classificados tanto no grupo Generalistas como no grupo das Espécies Cripticas ("Gm/Cr"). A área também apresenta nove espécies do gênero Camponotus pertencente ao grupo "Ca"; além dos grupos "Cr" representado pelo gênero Wasmannia com duas espécies; o grupo "Gm" representado pelo gênero Crematogaster com uma espécie; e o grupo "Ab" representado pelo gênero Pseudomyrmex com uma espécie. O gênero Paratrechina não foi classificado em nenhum dos grupos funcionais (Figura 57).

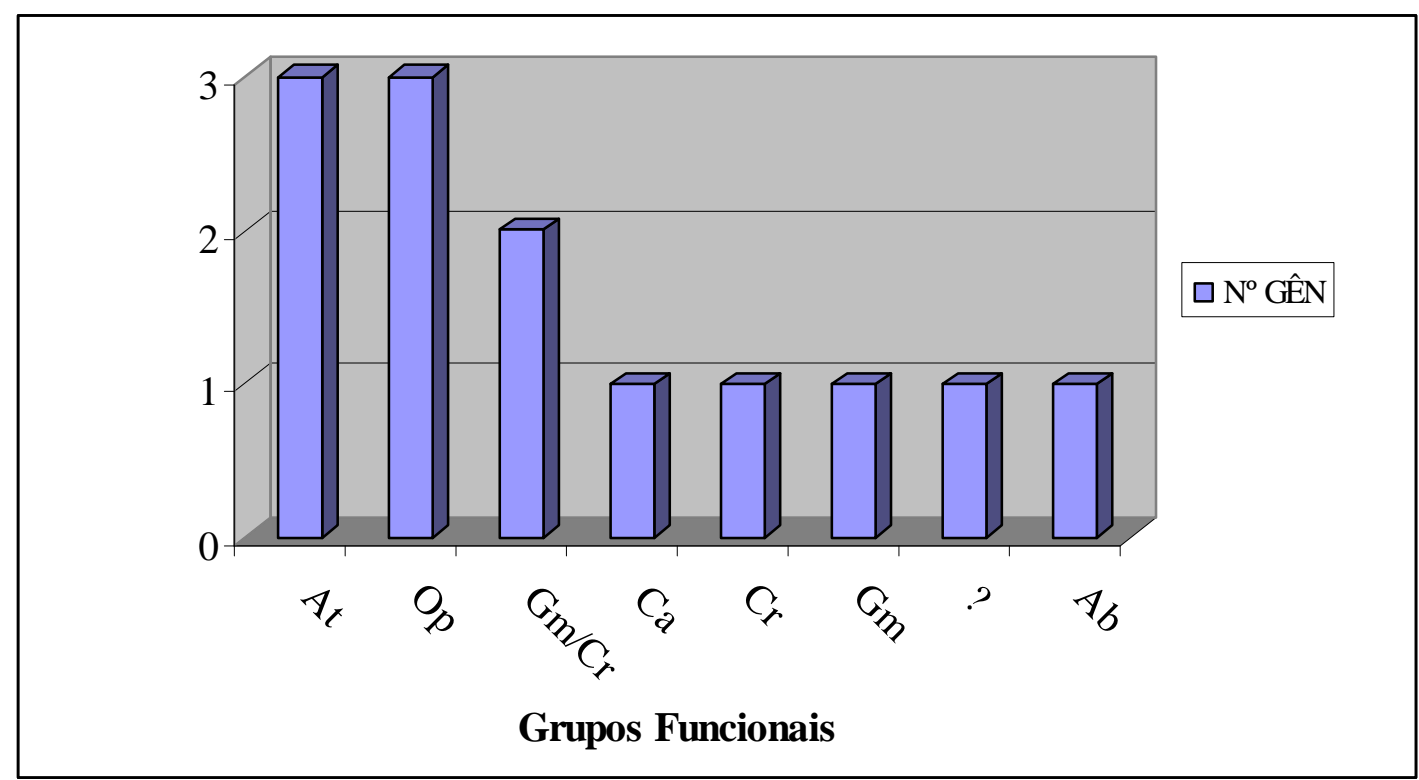

Legenda: $\mathrm{Pr}=$ Predadoras Especialistas; $\mathrm{Ca}=$ Camponotus; $\mathrm{Gm}=$ Generalistas Myrmicines; $\mathrm{Op}=$ Oportunistas; $\mathrm{DD}=$ Dominantes Dolichoderinae; $\mathrm{Cr}=$ Criptica; At $=$ Attini; Ec $=$ Ecitonini; $\mathrm{Ab}=$ Arboreal; ? = grupo não definido.

Figura 57 - Gêneros registrados em cada grupo funcional na Área 1995 (A95). 
Observando a Figura 57, nota-se que esta área é representada em cerca de $61 \%$ pelos seguintes grupos funcionais: Attini (At) e Oportunistas (Op) com cerca de $23 \%$ de representatividade cada, e os gêneros que podem ser classificados tanto como Generalistas como Cripticas (Gm/CR) com cerca de $15 \%$ de representatividade. Já os demais grupos funcionais representam ao todo cerca de $32 \%$ dos grupos presentes na área. Além disto, cerca $7 \%$ dos gêneros não foram classificados em nenhum dos grupos funcionais.

\section{Área $2000(\mathrm{A00})$}

Foram registrados, para esta área, 10 gêneros contendo 14 espécies diferentes, sendo o grupo "Op" representado pelos gêneros Dorymyrmex, Ectatomma e Gnamptogenys com uma espécie cada; e os gêneros Pheidole e Solenopsis, ambos com duas espécies de cada, podendo ser classificados tanto no grupo Generalista como no grupo das Espécies Cripticas ( $\mathrm{Gm} / \mathrm{Cr}$ ). A área também apresenta três espécies do gênero Camponotus pertencente ao grupo funcional "Ca"; o grupo "At" representado pelo gênero Acromyrmex com uma espécie; o grupo "Gm" representado pelo gênero Crematogaster com uma espécie; e o grupo "Ab" representado pelo gênero Pseudomyrmex com uma espécie. O gênero Cephalotes não foi classificado em nenhum dos grupos funcionais (Figura 58). 


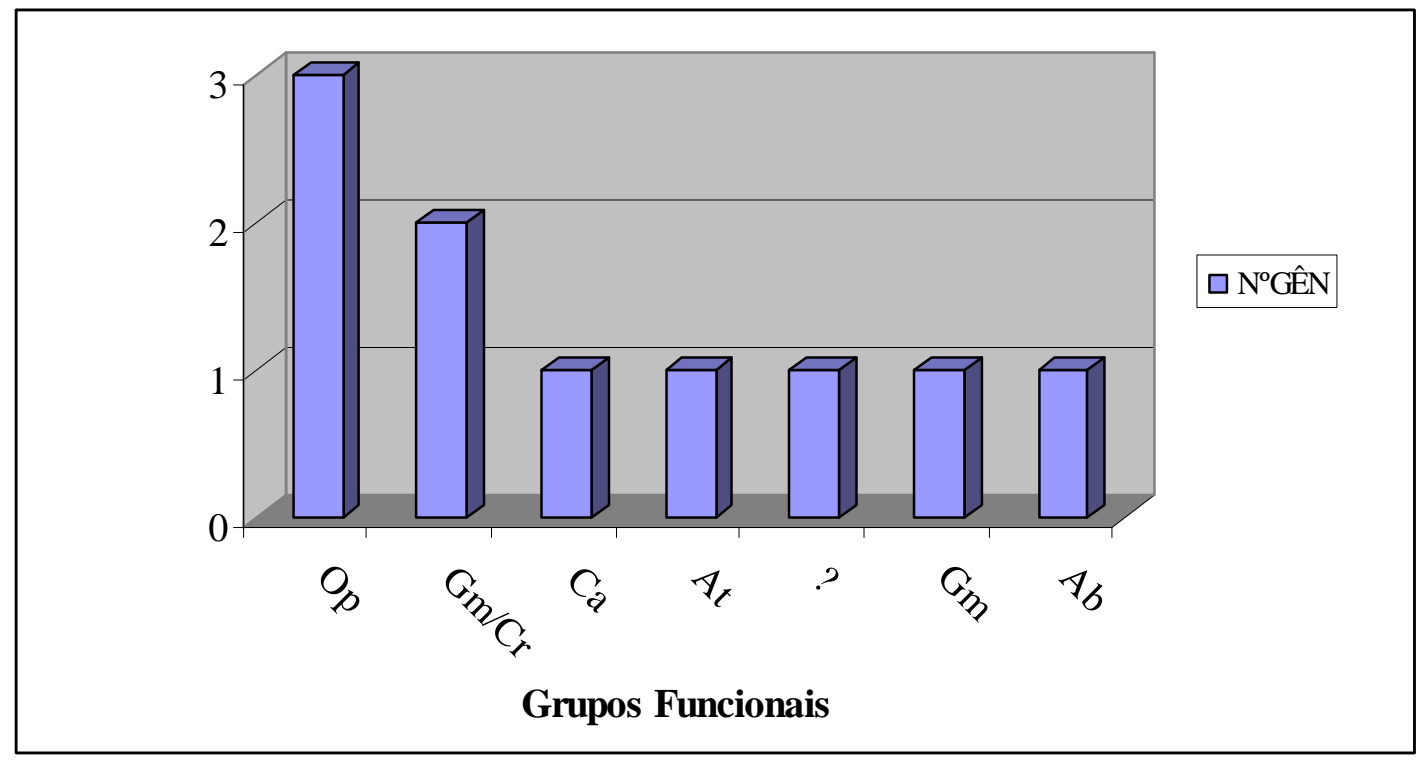

Legenda: $\mathrm{Pr}=$ Predadoras Especialistas; $\mathrm{Ca}=$ Camponotus; $\mathrm{Gm}=$ Generalistas Myrmicines; $\mathrm{Op}=$ Oportunistas; $\mathrm{DD}=$ Dominantes Dolichoderinae; $\mathrm{Cr}=$ Criptica; At = Attini; Ec $=$ Ecitonini; $\mathrm{Ab}=$ Arboreal; ? = grupo não definido.

Figura 58 - Gêneros registrados em cada grupo funcional na Área 2000 (A00).

Visualizando a figura 58 , nota-se que esta área é representada em $50 \%$ pelos seguintes grupos funcionais: Oportunista $(\mathrm{Op})$ com $30 \%$ de representatividade, e pelos gêneros que podem ser classificados tanto ao grupo Generalista como no grupo das Espécies Cripticas ( $\mathrm{Gm} / \mathrm{Cr}$ ) com $20 \%$ de representatividade. Já os demais grupos funcionais representam $40 \%$ ( $\mathrm{Ca}$, At, Gm e Ab com 10\% cada) de todos os grupos presentes na área. Além disto, $10 \%$ dos gêneros não foram classificados em nenhum dos grupos funcionais.

A possibilidade de classificação dos bioindicadores (formigas) em "Grupos Funcionais" permite realizar comparações funcionais entre composição de espécies dos diferentes ambientes, não somente levando em consideração uma lista de espécie por localidades, mas também confrontando os modelos estruturais das associações, possibilitando a revelação de diferenças na ecologia das comunidades observadas.

Assim, a classificação das formigas em "Grupos Funcionais" permite um melhor entendimento e avaliação das espécies em relação à sua estruturação em determinados ambientes, possibilitando uma provável avaliação do ambiente em termos do grau de sucessão ecológica das espécies e sua capacidade de autosustentabilidade, determinando o nível de evolução das áreas em processo de recuperação. 
A classificação dos grupos funcionais de ANSDERSEN (2000) e BROWN JR (2000) foi desenvolvida para analisar as formigas da Austrália e América do Norte. Essa análise considera essencialmente o nível de modificação do habitat como um condicionador à ocorrência de grupos funcionais nesses habitats.

Seguindo a classificação de ANDERSEN (2000) e BROWN JR (2000), os três grupos mais abundantes, nesse estudo, foram "TCS", "GM" e "O", os quais ocorreram em todas as áreas, sendo que não ficaram evidentes diferenças significantes na freqüência dos grupos funcionais presentes nas áreas, conforme se observa na Figura 59.

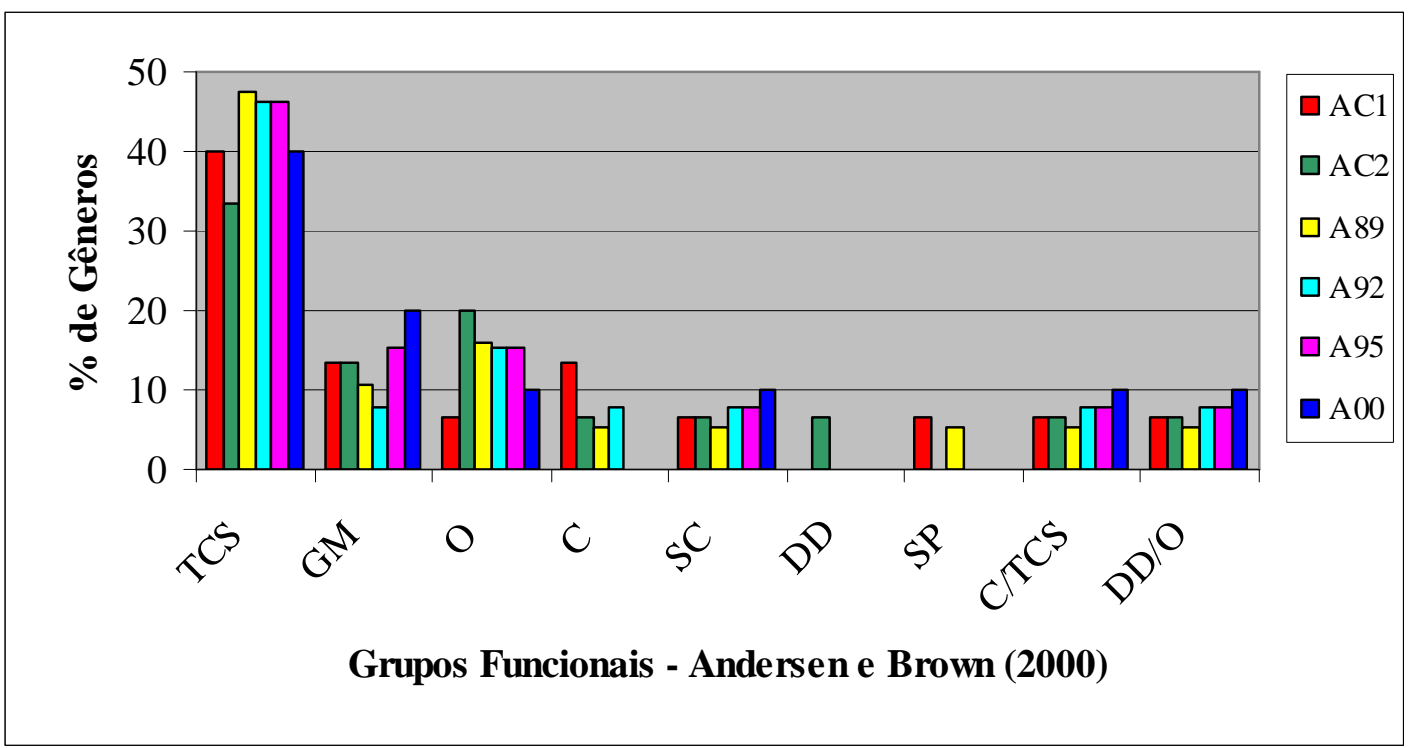

Legenda: $\mathrm{GM}=$ Generalistas Myrmicinae; DD = Dominante Dolichoderinae; $\mathrm{O}=$ Oportunistas; $\mathrm{C}=$ Espécies Crípticas; $\mathrm{SP}=$ Predadoras Especialistas; $\mathrm{TCS}=$ Especialistas de Clima Tropical; e SC = Subordinada Campotini.

Figura 59 - Comportamento dos grupos funcionais classificados por Andersen e Brown, nas seis áreas desse estudo.

Como já mencionado, as áreas A00, A95 e A92 possuem um desenvolvimento inicial do processo de sucessão vegetal, por se tratarem de áreas com plantio recente que possuíam 2, 7 e 10 anos respectivamente de desenvolvimento da vegetação, na época em que as formigas foram coletadas. A área A89 é a mais antiga em termos de recuperação, com um desenvolvimento mais avançado do processo de sucessão vegetal, possuindo 13 anos na época em que as formigas foram coletadas, e as áreas AC1 e AC2 trata-se de áreas próximas da mineração, mas que não foram e nem serão alterados diretamente pelo processo de lavra. 
Assim, é esperado que estas áreas devam apresentar diferenças funcionais em relação às diferentes etapas de sucessão apresentadas pelas áreas, onde as áreas $A C 1$ e AC2 devam apresentar comunidades de formigas mais próximas a ambientes inalterados e as áreas mais novas no processo de recuperação apresentar comunidades de formigas funcionalmente semelhantes àquelas de ambientes perturbados.

Então, fica evidente que o método global de grupos funcionais para as formigas, tem uma aplicabilidade limitada em relação às comunidades de formigas neotropicais. Por exemplo: as espécies que pertencem ao grupo das "DD" segundo ANDERSEN (2000) predominam em ambientes com baixo nível de estresse, ou seja, ambientes bem preservados. Esta informação não é verdadeira para este estudo, já que esse grupo exibiu baixa diversidade e abundância em todas as áreas. Assim, fica evidente que o perfil do grupo "DD" se enquadra melhor em comunidades extra tropicais.

Além disso, os grupos "TCS" e "GM", por serem muito diversos e abundantes, poderiam ser subdivididos na visão de vários tipos de ambientes e comportamento exibidos pelas espécies que integram esses dois grupos, como o gênero Pheidole do grupo "GM" que possui mais de 600 espécies, apenas nas Américas, sendo que a maioria delas se difere na estrutura da colônia, comportamento e relação com seus ambientes (WILSON, 2003). Mesmo assim, ANDERSEN (2000) e BROWN JR (2000) classificam-nas em um único grupo, o qual ainda contém 427 espécies de Crematogaster e 296 espécies de Monomorium.

A classificação dos grupos funcionais de BESTELMEYER e WIENS (1996), para as formigas do Chaco argentino parece aproximar uma classificação ideal em relação aos seus trópicos, onde os grupos mais diversos são subdivididos, como as formigas operárias (Subfamílias: Acnictinae, Dorylinae e Ecitoninae) e as formigas cultivadoras de fungos (Tribo Attini) que desenvolvem papéis importantes e únicos em nosso ecossistema (HÖLLDOBLER; WILSON, 1990), são classificados em grupos separados na classificação de BESTELMEYER e WIENS (1996).

Seguindo a classificação de BESTELMEYER e WIENS (1996), os grupos mais abundantes, neste estudo, foram "Op", "At", "Cr", e os gêneros Pheidole e Solenopsis (Gm/Cr); dos quais os grupos "Op", "At" e "Gm/Cr" ocorreram em todas as áreas. De todos os grupos classificados é possível evidenciar algumas diferenças 
significantes no comportamento de alguns grupos funcionais presentes na área, conforme podemos observar na Figura 60.

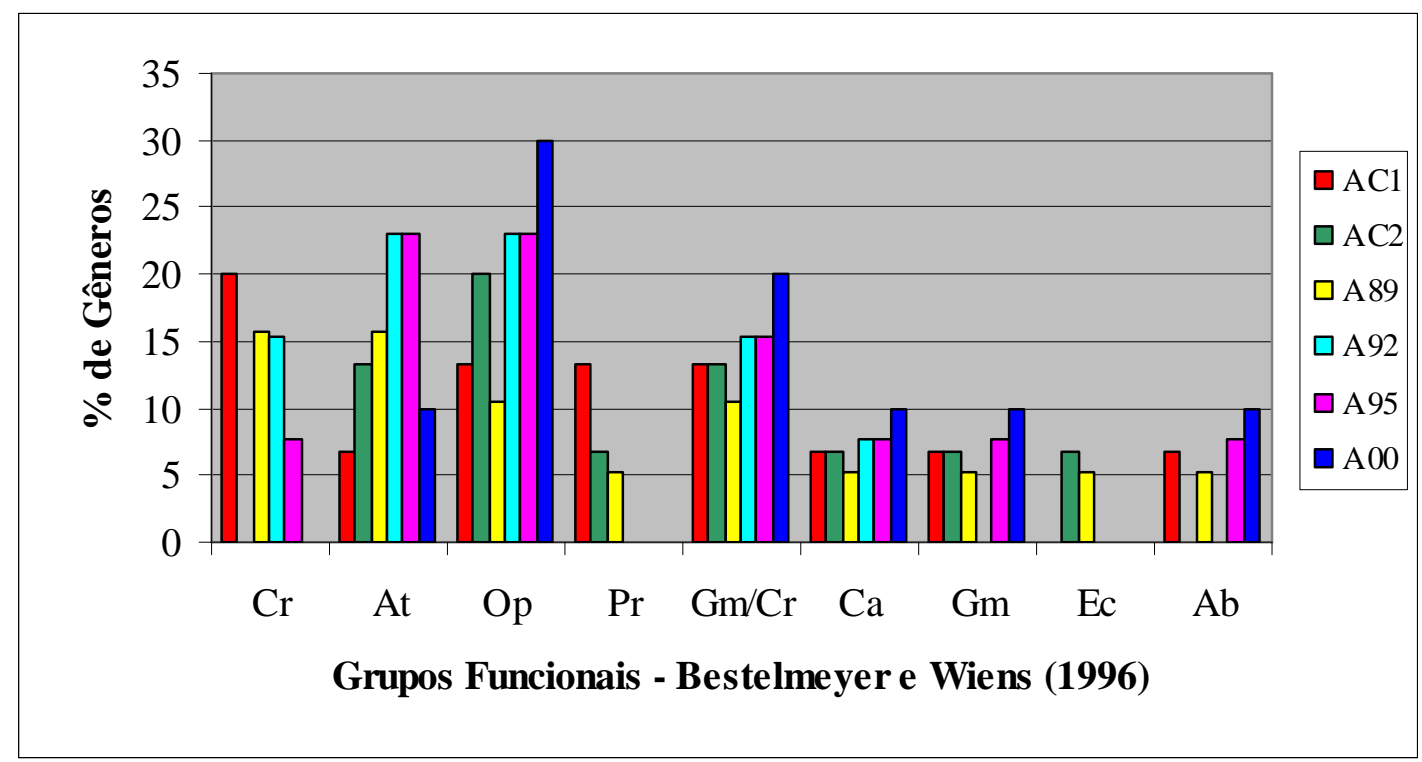

Legenda: $\mathrm{Pr}=$ Predadoras Especialistas; $\mathrm{Ca}=$ Camponotus; $\mathrm{Gm}=$ Generalistas Myrmicines; $\mathrm{Op}=$ Oportunistas; $\mathrm{DD}=$ Dominantes Dolichoderinae; $\mathrm{Cr}=$ Criptica; At $=$ Attini; $\mathrm{Ec}=$ Ecitonini; $\mathrm{Ab}=$ Arboreal; ? = grupo não definido. AC1 = Área Controle 1; AC2 = Área Controle 2; A89 = Área de plantio 1989; A92 = Área de plantio 1992; A95 = Área de plantio 1995; A00 = Área de plantio 2000.

Figura 60 - Comportamento dos grupos funcionais classificados por Bestelmeyer e Wiens, nas seis áreas desse estudo.

O grupo "Cr" caracterizado com alta representatividade em ambientes de moderado a altamente recuperados, e baixa representatividade em ambientes de moderado a altamente degradados (BESTELMEYER; WIENS, 1996); foram mais abundantes na AC1 com 20\% de representatividade, na A89 com 16\%, A92 com $15 \%$ e $A 95$ com $8 \%$ de representatividade, esse grupo foi ausente na área AC2 e na área A00. O grupo das "Pr" caracterizado com ocorrência de maior abundância em ambientes recuperados (BESTELMEYER; WIENS, 1996), estavam presentes nas áreas $A C 1$ com $13 \%$ de representatividade, na área $A C 2$ com $7 \%$, e na área $A 89$ com $5 \%$ de representatividade. Nas áreas A92, A95 e A00, este grupo foi totalmente ausente nesta etapa do monitoramento.

Os demais grupos "At”, "Op”, “Gm/Cr", "Ca”, "Gm”, “Ec”, e "Ab”, não revelaram respostas significantes em relação às diferentes etapas do processo de recuperação das áreas deste estudo. O grupo "Op" caracterizado como mais abundantes em áreas altamente degradadas, exceto, nos ambientes altamente recuperados (BESTELMEYER; WIENS, 1996) foi mais representativo nas áreas com estágios 
iniciais de sucessão vegetal, apresentando alta representatividade (30\%) na área A00, menor representatividade (10\%) na área A89, mas nas áreas de referência apresentaram maior representatividade deste grupo, em relação à área mais evoluída em termos de recuperação (AC1 com 13\% e AC2 com 20\%).

O grupo "At" caracterizado por (BESTELMEYER; WIENS, 1996) como mais abundantes em ambientes moderadamente recuperados, em relação aos ambientes altamente e moderadamente degradados; nesse estudo apresentou maior representatividade nas áreas menos recuperadas (A95 e A92 com 23\% cada, A89 com 15\%, AC2 com 13\% e AC1 com 6\%), com exceção da A00 (com 10\%). O grupo "Gm/Cr" apresentou baixa variabilidade entre as áreas, sendo um pouco mais representativo na $A 00$, com cerca de $5 \%$ de representatividade a mais em relação às demais áreas.

Os resultados das análises aplicadas possibilitaram definir o nível de evolução de cada área de coleta, diante das técnicas de revegetação adotada. A análise de diversidade identificou a riqueza e a dominância de espécies de formigas presentes em cada área de coleta, a análise de afinidade determionou a complexidade da paisagem e, juntamente com a análise de agrupamento foi possível estimar e visualizar a similaridade das áreas e, por fim, a análise de grupos funcionais que possibilitou compreender a variação da estrutura e da função da comunidade de formigas presentes no local de estudo.

Assim, considerando a área de coleta mais evoluída (A89), foi registrada alta diversidade e complexidade da paisagem, preseça de dominância de espécies e presença de grupos funcionais indicadores de qualidade ambiental. A partir destes resultados e com base na teoria da sucessão ecológica das espécies (Figura 61) é possível estimar o nível de recuperação e definir com razoável precisão a eficácia das técnicas de revegetação adotadas. 


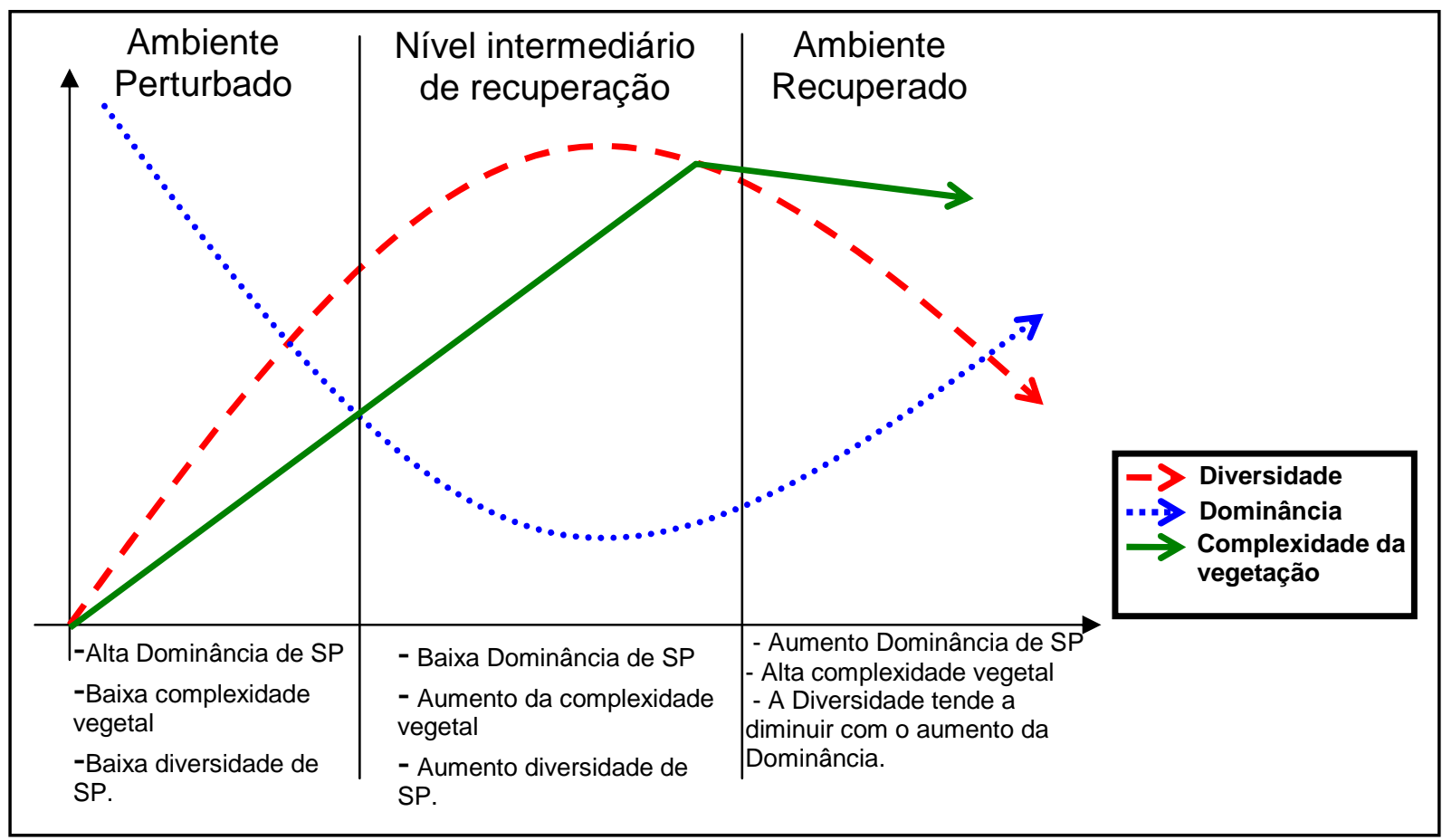

Figura 61 - Correlação esquemática existente entre diversidade e dominância de espécies.

Cabe salientar que a figura 61 é apenas um esquema elaborado a partir da teoria da sucessão ecológica, para facilitar o entendimento e melhor visualizar o nível de evolução registrado a partir dos resultados analisados, sendo que os pontos exatos de contatos devem ser redefinidos ao longo do biomonitoramento ambiental. 


\section{CAPÍTULO 6}

\section{CONCLUSÕES}

Desenvolver e colocar em prática, métodos de monitoramento ambiental capaz de fornecer dados reais que possam ser coletados ao longo de toda a vida da mina é uma tarefa exigida legalmente pelos órgãos ambientais, a qual deve ser aceita pelas minerações como uma imposição positiva, que auxilia e beneficia 0 empreendimento e a comunidade envolvida.

A partir da prática de biomonitoramento ambiental é possível desenvolver e acompanhar o desenvolvimento das atividades relacionadas à recuperação do ambiente modificado. Quando desenvolvido com técnicas apropriadas, o biomonitoramento ambiental é capaz de auxiliar e direcionar, de maneira bastante eficaz, o gerenciamento das atividades ambientais.

A metodologia aplicada obteve sucesso nas coletas e análise dos dados, atingindo o objetivo deste estudo, pois ficaram comprovados o baixo custo de investimento, a eficácia e a praticidade apresentada pela metodologia proposta, uma vez que, foram capturadas quantidade e diversidade significativas de espécies de formigas ao longo de todas as áreas de coletas.

Além disso, com os dados analisados, foi possível verificar a evolução das áreas em diferentes estágios de recuperação, possibilitando a verificação da necessidade de se introduzir ajustes ou mudança de estratégias para a manutenção das áreas, visando melhorar os métodos utilizados no PRAD e melhor direcionar o manejo no processo de recuperação.

O acréscimo de uma segunda área controle $(A C 2)$ permitiu verificar que a baixa diversidade determinada na primeira área controle (AC1) é um fato característico do tipo de vegetação encontrado na região, constatando uma pequena diferença da diversidade de ambas as áreas, mesmo se tratando de áreas próximas, porém, distintas em relação ao porte de algumas espécies vegetais. 
Sempre que possível, um maior número de áreas controle devem ser incluídas no monitoramento, visto que elas servem de referência para as variações biológicas que ocorrem naturalmente nas populações de formigas, evitando que esta variação espacial acabe por camuflar a detecção das respostas relacionadas às perturbações.

A abordagem mais segura é reter informações detalhadas da composição da comunidade e registrar a abundância de espécies individuais, contudo, uma ligação com o processo de pós-coleta deve ser considerada, para evitar um maior custo na fase de identificação das formigas coletadas. A alternativa seria a classificação das formigas em escalas mais comuns, como realizar identificações apenas ao nível de gênero, e oferecer generalizações úteis com um mínimo de experiência prévia e com o esforço altamente reduzido. Mesmo assim, na maioria dos casos um taxonomista especialista em formigas deve ser consultado para estabelecer um programa de monitoramento bem sucedido.

Todos os efeitos de monitoração são enfrentados com o desafio de arquivar, integrar e visualizar os dados monitorados, 0 que exige um adequado armazenamento desses dados. Assim, deve-se dar ênfase à importância da correta etiquetagem dos frascos e armazenamento dos dados coletados, e de suas respectivas identificações, evitando a perda de informações e garantindo uma análise completa.

Com a análise de diversidade foi possível concluir que a área mais avançada no processo de recuperação (A89) se encontra em estágio intermediário de recuperação, visto que ficou constatada uma riqueza de espécies maior do que a riqueza apresentada nas áreas controle (AC1 e AC2). O ponto exato deste estágio intermediário pode ser estabelecido ao longo do monitoramento ambiental, o que permitirá a elaboração de hipóteses sobre o ecossistema em questão.

Os ambientes amostrados evidenciaram alta complexidade ambiental, o que foi percebido através do baixo valor de similaridade de espécies entre as áreas de estudo e $o$ alto índice de diversidade mosaico $(\mathrm{m})$. A análise de agrupamento ao nível de gênero evidenciou e permitiu uma visualização da evolução temporal das áreas em processo de recuperação, as quais tendem a uma resposta positiva quanto à evolução da sucessão ecológica local.

A indicação qualitativa da real situação encontrada nas áreas avaliadas foi permitida por meio do estudo da avaliação da estrutura funcional que as formigas 
representam em cada área de coleta, uma vez que foi possível definir, através da classificação de BESTELMEYER e WIENS (1996), de uma maneira simplificada, a fauna de formigas registradas, em grupos indicadores.

Alguns grupos funcionais evidenciaram um comportamento previsível caracterizando e diferenciando a composição das comunidades de formigas entre as diferentes etapas de recuperação, avaliadas neste estudo, por exemplo, os grupos das Predadoras (Pr) e das espécies Crípticas ( $\mathrm{Cr}$ ) como indicadores de qualidade ambiental e o grupo das Oportunistas (Op) como indicador de perturbação ambiental.

Além disso, como resultado das identificações, gerou-se um catálogo de todas as espécies, no qual pelo menos um indivíduo foi fixado e catalogado, possibilitando o início de uma coleção, que permitirá e facilitará identificar, por comparação, das futuras coletas de formigas, em que há a possibilidade da identificação apenas de novas espécies ou gêneros. Este fato contribuirá para reduzir ainda mais o custo da aplicação do monitoramento. A coleção deverá ser complementada com a adição de novas espécies que deverão ser coletadas com a continuidade do biomonitoramento ambiental da área de estudo.

Nem sempre são capturadas espécies de formigas indicadoras de ambiente totalmente recuperado. Entretanto, a estrutura da comunidade de formigas pode ser considerada como indicativo de uma evolução eficaz do método de recuperação utilizado. Este tipo de ambiente pode ser caracterizado por possuir alta diversidade de espécies e não apresentar dominância acentuada de uma ou poucas espécies, como ocorre nos casos de ambientes mais perturbados (SMITH et al., 1992).

Além disso, muitas perguntas podem não ser respondidas de imediato (em curto prazo), ou seja, apenas com o primeiro levantamento de espécies, mas sim, com a continuidade deste estudo, já que se trata de um monitoramento ambiental que deve ser repetido em intervalos de tempo pré-determinado de acordo com o interesse e necessidades gerenciais. O tempo de manejo necessário para que uma área seja considerada totalmente recuperada, deverá ser estabelecido de acordo com as respostas apresentadas ao longo do avanço do monitoramento ambiental.

Como recomendações, é possível sugerir um acompanhamento contínuo do desenvolvimento das espécies vegetais das áreas recuperadas, das condições do solo (análise química de fertilidade) e da composição da fauna local, para que estas áreas alcancem um estado "ecologicamente satisfatório", ou seja, atinjam sua auto- 
sustentabilidade, evitando a dominância de espécies vegetais exóticas, como por exemplo, às utilizadas no processo de recuperação da área de estudo, a saber, quebra-ventos.

Estas recomentações são relevantes uma vez que o processo de revegetação tem por objetivo uma recuperação auto-sustentável, e o manejo deve ser aplicado até o início do estabelecimento de um equilíbrio ambiental, com a recuperação do potencial biótico da área e a melhoria das condições estéticas da paisagem. Portanto, o manejo deverá ser bem direcionado, sempre objetivando auxiliar o gerenciamento ambiental na área em questão. 


\section{REFERÊNCIAS BIBLIOGRÁFICAS}

ALLABY, M. The concise Oxford dictionary of Zoology. Oxford: Oxford University Press,..1992. 442p.

ALMEIDA, R.O.P.O. Revegetação de areias mineradas: estudo dos procedimentos aplicados em mineração de areia. 2002. 160 p. Dissertação (Mestrado) - Escola Politécnica, Universidade de São Paulo, São Paulo, 2002.

ALONSO, L.E. Ants as indicators of diversity. In: AGOSTI, D.; MAJER, J. D.; ALONSO, L.E.; SCHULTZ, T.R. (Ed.). Ants - standard methods for measuring and monitoring biodiversity. Washington: Smithsonian Institution Press, 2000. p. 80-88. Disponível em: <http:/www.antbase.org/ants>. Acesso em: 27 nov 2006.

ALVARENGA, F.C.; ROSADO, S.C.S. ; SIQUEIRA, J.O. Growth of trema micrantha provenances inoculated with micorhizal fungi. In: INTERNATIONAL CONFERENCE ON MYCORRHIZAE, 1st., 1996, Berkeley. Proceedings. Berkeley: University Press, 1996. p. 1-32. *

ANDERSEN, A.N. Ant community organization and environmental assessment. In: MAJER, J.D. (Ed.). The role of invertebrates in conservation and biological survey, [s.L.]: Western Australian Department of Conservation and Land Management Report, 1987. p.43-52.

ANDERSEN, A.N. A classification of australian ant communities, based on functional groups which parallel plant life forms in relation to stress and disturbance. Journal of Biogeography, Oxford, n. 22, p. 15-29, 1995.

ANDERSEN, A.N. Using ants as bioindicators: multiscale issues in ant community ecology. Conservation ecology. 1997. Disponível em: http://www.consecol.org/vol1/iss1/art8>. Acesso em: 14 jan. 2007.

ANDERSEN, A.N. Global ecology of rainforest ants. In: AGOSTI, D.; MAJER, J D.; ALONSO, L.E.; SCHULTZ, T.R. (Ed.). Ants - Standard methods for measuring and monitoring biodiversity. Washington, D.C.: Smithsonian Institution Press, 2000. p. 25-34. 
ARCILA, A.M.; LOZANO-ZAMBRANO, F.H. Hormigas como herramienta para la bioindicacion y el monitoreo. In: FERNÁNDEZ, F. (Ed.). Introducción a las hormigas de la región neotropical. Bogotá : Instituto de Investigación de Recursos Biológicos Alexander von Humboldt, 2003. p. 159-166. Disponível no site: http://www.antbase.org/databases/publications_files/publications_20239.htm.

ASSOCIAÇÃO BRASILEIRA DE NORMAS TÉCNICAS.Degradação do solo terminologia. NBR 10.703. Rio de Janeiro: ABNT, 1989.

BARROSO, D.G. Estudos de alguns atributos químicos e físicos dos substratos utilizados no processo de estabilização de dunas de rejeito resultantes da exploração mineral. 1994. 58 p. Dissertação (Mestrado) - Escola Superior de Agricultura de Lavras, Lavras, 1994.

BARTH, R.C. Avaliação da recuperação de áreas mineradas no Brasil. Viçosa: Universidade Federal, 1989. 41 p. (Boletim Técnico. n. 1).

BESSA, H. Relatório final de pesquisa para zircão em Mataraca - Paraíba. Rutilo e Ilmenita do Brasil S.A., Mataraca - PB. Areias: Universidade, 1975. 17p.

BESTELMEYER, B.T.; WIENS, J.A. The effects of land use on the structure of ground-foraging ant communities in the Argentine Chaco. Ecological Applications, Washington, v. 6, n. 4, p. 1225-1240, 1996.

BESTELMEYER, B.T; AGOSTI, D.; ALONSO, L.E; BRANDÃO, C.R.F.; BROWN JR, W.L.; DELABIE, J.H.C.; SILVESTRE, R. Field Tecniques for the study of grounddwelling ants: an overview, description, and evaluation. In: AGOSTI, D.; MAJER, J D.; ALONSO, L.E.; SCHULTZ, T.R. (Ed.). Ants - Standard methods for measuring and monitoring biodiversity. Washington, D.C.: Smithsonian Institution Press, 2000. p.122-144. Disponível em: <http:/www.antbase.org/ants/>.

BISSET, R. Methods for environmental impact analysis recent trends and future prospects. Journal of Environmental Management, New York, v. 11, p. 27-43, 1980.

BITAR, O.Y.; BRAGA, T.O. O meio físico na recuperação de áreas degradadas. In: BITAR, O.Y. (Coord.) Curso de geologia aplicada ao meio ambiente. São Paulo: ABGE/IPT, 1995. p. 165-179. (Série Meio Ambiente). 
BITAR, O.Y. Avaliação da recuperação de áreas degradadas por mineração na região metropolitana de São Paulo. 1997. 185 p. Dissertação (Mestrado) - Escola Politécnica da Universidade de São Paulo, São Paulo, 1997.

BONNET, A.; LOPES, B.C. Formigas de dunas e restingas da praia de Joaquina, Ilha de Santa Catarina, SC (Insecta: Hymenoptera). Biotemas, Florianópolis, v. 1, n. 6, p. 107-114, 1993.

BOWLES, M.L.; WHELAN, C. Restoration of endangered species. Cambridge: University Press, 1994. $394 \mathrm{p}$.

BRANDÃO, C.R.F. Hymenoptera, formicidae. In: Brandão, C.R.F.; Cancello, E.M. (Ed.) Biodivesidade do estado de São Paulo: síntese do conhecimento ao final do século XX. 5 - invertebrados terrestres. São Paulo: FAPESP,1999. p. 213-223.

BRANDI, I.V. Estudos da efetividade dos planos de recuperação de áreas degradadas (PRADs) de atividades de explotação de minério de ferro na região do quadrilátero ferrífero - MG. 1994. 114 p. Dissertação (Mestrado) - Escola de Engenharia de São Carlos, Universidade de São Paulo, São Carlos, 1994.

BROWN, K.S. Diversity, disturbance, and sustainable use of neotropical forest: insects as indicators for conservation monitoring. Journal of Insect Conservation, Dordrecht, v. 1, n. 1, p. 25-42, 1997.

BROWN JUNIOR, W.L. Diversity of ants. In: AGOSTI, D.; MAJER, J.D.; ALONSO, L.E.; SCHULTZ, T.R. (Ed.). Ants - Standard methods for measuring and monitoring biodiversity. Washington: Smithsonian Institution Press, 2000. p. 4579. (Biological Diversity Handbook Series). Disponível em: <http:/www.antbase.org/ants/>.

CAETANO, F.H.; JAFFÉ, K.; ZARA, F.J. Formigas: biologia e anatomia. 2. ed. Araras: Topázio, 2002. $131 \mathrm{p}$.

CAMPELLO de CASTRO, J.P. Reabilitação de áreas degradadas - aspectos legais. In: DIAS, L.E.; MELLO, J.W.V. (Ed.). Recuperação de áreas degradadas. Viçosa: Universidade Federal de Viçosa, Departamento de Solos, 1998. p. 9-13.

CAMPOS-FARINHA, A.E.; JUSTI JÚNIOR , J.; BERGMANN, E.C.B.; ZORZENON, F.J.; RODRIGUES NETTO, S.M. Formigas urbanas. Boletim Técnico. Instituto de Biociências, São Paulo, n. 8, p. 5-20, set. 1997. 
CANADA. Ontario Ministry of Northern Development and Mines. Rehabilitation of Mines Guidelines for proponents. Ontario, 1995.

CARNEIRO, J.S. Padrões da riqueza de espécies arbóreas em fragmentos ao longo de gradientes latitudinais e longitudinais. 1999. 39 p. Monografia (Graduação) - Universidade Estadual Paulista, Rio Claro, 1999.

CAVALCANTI, R.N. Mineria, desarrolo y médio ambiente. In: REPETTO, F.L.; KAREZ, C.S. (Ed.). Aspectos geológicos de protección ambiental. Montevideo: UNESCO, 1995. p. 105-109. Notas de aula do curso Formación en Aspectos Geológicos de Protección Ambiental, IG-UNICAMP.

CAVALCANTI, R.N. Gestion ambiental. In: CURSO INTERNACIONAL DE ASPECTOS GEOLÓGICOS DE PROTECCIÓN AMBIENTAL, 2., 2000, Campinas. . Notas de clases. Montevideo: UNESCO, 2002. p. 37-45.

CUNHA, L.O; Mineração e recuperação de áreas degradadas no litoral da Paraíba.1995. 22 p. Monografia (Graduação) - Universidade Federal de Lavras, Departamento de Ciências Florestais, Lavras, 1995.

CUNHA, L.O. Aspectos técnicos e econômicos da reabilitação de dunas litorâneas mineradas em Mataraca, Paraíba. 1997. 72 p. Dissertação (Mestrado) Universidade Federal de Lavras, Lavras, 1997a.

CUNHA, L.O. Aspectos técnicos e econômicos da reabilitação de dunas litorâneas mineradas em Mataraca. Lavras: Departamento de Ciências do Solo da UFLA, 1997b. 32 p. (Relatório Técnico).

CUNHA, L.O.; FONSECA, C.G; SILVA, G.J.M.; ARAÚJO, L.S.; SILVA, M.B.M.; FALCÃO, M.A.; ALCÂNTARA; R.M.; SILVA, A.L.; SILVA, C.S.; FARIAS FILHO, E.; MEDEIROS, J.F.; CUNHA FILHO, J.C.; SILVA, M.E.M.; NÓBREGA, R.M.; SILVA, R.A. Acompanhamento do plano de controle ambiental (PCA) do projeto de lavra e beneficiamento de ilmenita, zirconita e rutilo, em uma área de 1123ha, no município de Mataraca - PB. Mataraca: Rutilo e Ilmenita do Brasil S.A., 1998a. 15 p. Data do protocolo 1998. Atividades de dez./97 à jul./98. 
CUNHA, L.O.; FONSECA, C.G; SILVA, G.J.M.; ARAÚJO, L.S.; SILVA, M.B.M.; FALCÃO, M.A.; ALCÂNTARA; R.M.; SILVA, A.L.; SILVA, C.S.; FARIAS FILHO, E.; MEDEIROS, J.F.; CUNHA FILHO, J.C.; SILVA, M.E.M.; NÓBREGA, R.M.; SILVA, R.A. Acompanhamento do plano de controle ambiental (PCA) do projeto de lavra e beneficiamento de ilmenita, zirconita e rutilo, em uma área de 1123ha, no município de Mataraca - PB. Mataraca: Rutilo e Ilmenita do Brasil S.A., 1998b. 13 p. Data do protocolo 1998. Atividades de ago./98 à dez./98.

CUNHA, L.O.; FONSECA, C.G; SILVA, G.J.M.; ARAÚJO, L.S.; SILVA, M.B.M.; FALCÃO, M.A.; ALCÂNTARA; R.M.; SILVA, A.L.; SILVA, C.S.; FARIAS FILHO, E.; MEDEIROS, J.F.; CUNHA FILHO, J.C.; SILVA, M.E.M.; NÓBREGA, R.M.; SILVA, R.A. Acompanhamento do plano de controle ambiental (PCA) do projeto de lavra e beneficiamento de ilmenita, zirconita e rutilo, em uma área de 1123ha, no município de Mataraca - PB. Mataraca: Rutilo e Ilmenita do Brasil S.A., 1999a. 18 p. Data do protocolo 1999. Atividades de jan./99 à jun./99.

CUNHA, L.O.; FONSECA, C.G; SILVA, G.J.M.; ARAÚJO, L.S.; SILVA, M.B.M.; FALCÃO, M.A.; ALCÂNTARA; R.M.; SILVA, A.L.; SILVA, C.S.; FARIAS FILHO, E.; MEDEIROS, J.F.; CUNHA FILHO, J.C.; SILVA, M.E.M.; NÓBREGA, R.M.; SILVA, R.A. Acompanhamento do plano de controle ambiental (PCA) do projeto de lavra e beneficiamento de ilmenita, zirconita e rutilo, em uma área de 1123ha, no município de Mataraca - PB. Mataraca: Rutilo e Ilmenita do Brasil S.A., 1999b. 15 p. Data do protocolo 2000. Atividades de jul./99 à dez./99.

CUNHA, L.O.; FONSECA, C.G; SILVA, G.J.M.; ARAÚJO, L.S.; SILVA, M.B.M.; FALCÃO, M.A.; ALCÂNTARA; R.M.; SILVA, A.L.; SILVA, C.S.; FARIAS FILHO, E.; MEDEIROS, J.F.; CUNHA FILHO, J.C.; SILVA, M.E.M.; NÓBREGA, R.M.; SILVA, R.A. Acompanhamento do plano de controle ambiental (PCA) do projeto de lavra e beneficiamento de ilmenita, zirconita e rutilo, em uma área de 1123ha, no município de Mataraca - PB. Mataraca: Rutilo e IImenita do Brasil S.A., 2000a. 16 p. Data do protocolo 2000. Atividades de jan./00 à jun./00. *

CUNHA, L.O.; FONSECA, C.G; SILVA, G.J.M.; ARAÚJO, L.S.; SILVA, M.B.M.; FALCÃO, M.A.; ALCÂNTARA; R.M.; SILVA, A.L.; SILVA, C.S.; FARIAS FILHO, E.; MEDEIROS, J.F.; CUNHA FILHO, J.C.; SILVA, M.E.M.; NÓBREGA, R.M.; SILVA, R.A. Acompanhamento do plano de controle ambiental (PCA) do projeto de lavra e beneficiamento de ilmenita, zirconita e rutilo, em uma área de 1123ha, no município de Mataraca - PB. Mataraca: Rutilo e Ilmenita do Brasil S.A., 2000b. 16 p. Data do protocolo 2000. Atividades de jul./00 à dez./00. * 
CUNHA, L.O; MENEZES, C.S.; SILVA, G.J.M.; CORREIA, K.G.; ARAÚJO, L.S.; SILVA, M.B.M.; CASTRO, R.; SILVA, A,L.; SILVA, C.S.; CAVALCANTI, I.M.P.; MEDEIROS, J.F.; CRUZ, J.A.V.; CUNHA FILHO, J.C.; NÓBREGA, R.M.; SILVA, R.A. Acompanhamento do plano de controle ambiental (PCA) do projeto de lavra e beneficiamento de ilmenita, zirconita e rutilo, em uma área de 1123ha, no município de Mataraca - PB. Mataraca: Rutilo e Ilmenita do Brasil S.A., 2001a. 22 p. Data do protocolo 2001. Atividades de jan./01 à jun./01.

CUNHA, L.O; MENEZES, C.S.; SILVA, G.J.M.; CORREIA, K.G.; ARAÚJO, L.S.; SILVA, M.B.M.; CASTRO, R.; SILVA, A,L.; SILVA, C.S.; CAVALCANTI, I.M.P.; MEDEIROS, J.F.; CRUZ, J.A.V.; CUNHA FILHO, J.C.; NÓBREGA, R.M.; SILVA, R.A. Acompanhamento do plano de controle ambiental (PCA) do projeto de lavra e beneficiamento de ilmenita, zirconita e rutilo, em uma área de 1123ha, no município de Mataraca - PB. Mataraca: Rutilo e Ilmenita do Brasil S.A., 2001b. 22 p. Data do protocolo 2001. Atividades de jul./01 à dez./01. *

DALE, V.H.; BEYLER, S.C. Challenges in the development an use of ecological indicators. Ecological Indicators, New York, v. 1, n. 1, p. 3-10, 2001.

DANTAS, J.R. Mapa geológico do estado da Paraíba - Texto explicativo. Campina Grande: CDRM, 1982. 134 p.

DELABIE, J.H.C.; AGOSTI, D.; NASCIMENTO, I.C. Litter ant communities of the Brazilian Atlantic rain forest region. In: AGOSTI, D.; MAJER, J.D.; ALONSO, L; SCHULTZ, T. Sampling ground-dwelling ants: case studies from the world's rain forest. Perth: Curtin University School of Environmental Biology, 2000. p.1-17. (Bulletin, n.18).

DIAS, L.E.; GRIFFITH, J.J. Conceituação e caracterização de áreas degradadas. In: DIAS, L.E.; MELLO, J.W.V. (Ed.). Recuperação de áreas degradadas. Viçosa: Universidade Federal de Viçosa. Departamento de Solos, 1998. p.1-7.

DIAS, E.G.C.S. Avaliação de impacto ambiental de projetos de mineração no Estado de São Paulo: a etapa de acompanhamento. 2001. 283 p. Tese (Doutorado) - Escola Politécnica, Universidade de São Paulo, São Paulo, 2001.

DOTE SÁ, T.; VASCONCELOS, H.O.M.; SALES JÚNIOR, L.G.; DANTAS, L.C.L; OLÍMPIO, M.L.D. Plano de controle ambiental (PCA) e atualização do plano de recuperação de áreas degradadas (PRAD), do projeto de lavra e beneficiamento de ilmenita e rutilo, em uma área de 1123 ha, no município de Mataraca, Estado da Paraíba. Mataraca: Rutilo e Ilmenita do Brasil S.A., 1993. 30 p. Data do protocolo dezembro 1993. Atividades de 1992. 
DOTE SÁ, T.; TEIXEIRA, M.L.; CUNHA, L.O.; OLIVEIRA FILHO, A.T.; FONSECA, C.G.; SILVA, G.J.M.; RODENAS, J.M.; SILVA, M.B.M.; DICK, W.W.; SILVA, R.A.; NÓBREGA, R.M.; SILVA, M.E.M.; SIQUEIRA, P.; SILVA, J.F.C.; CUNHA FILHO, J.C.; SILVA, F.F.; ARAÚJO, F.G.; FARIAS FILHO, E.; SILVA, C.S.; SILVA, A.L.; Acompanhamento do plano de controle ambiental (PCA) do projeto de lavra e beneficiamento de ilmenita, zirconita e rutilo, em uma área de 1123ha, no município de Mataraca - PB. Mataraca, Rutilo e Ilmenita do Brasil S.A., 1994a. 2 v. Data de protocolo março/1994. *

DOTE SÁ, T.; TEIXEIRA, M.L.; CUNHA, L.O.; OLIVEIRA FILHO, A.T.; FONSECA, C.G.; SILVA, G.J.M.; RODENAS, J.M.; SILVA, M.B.M.; DICK, W.W.; SILVA, A.L.; FARIAS FILHO, E.; ARAÚJO, F.G.; SILVA, F.F.; CUNHA FILHO, J.C.; SILVA, J.F.C.; SIQUEIRA, P.; SILVA, M.E.M.; NÓBREGA, R.M.; SILVA, R.A.; Acompanhamento do plano de controle ambiental (PCA) do projeto de lavra e beneficiamento de ilmenita, zirconita e rutilo, em uma área de 1123ha, no município de Mataraca PB. Mataraca, Rutilo e IImenita do Brasil S.A., 1994b. 47 p. Data de protocolo outubro/1994. Atividades desenvolvidas de abril a setembro de 1994.

DOTE SÁ, T. Mineração de ilmenita, zirconita e rutilo no sistema natural litorâneo da área da Mina Guaju no município de Mataraca-PB. 1995. 92 p. Monografia (Graduação) - Universidade Federal do Ceará, Departamento de Geologia, Fortaleza, 1995.

DOTE SÁ, T. Mineração de ilmenita, zirconita e rutilo no sistema deposicional litorâneo da área da Mina Guaju no Município de Mataraca -PB: impactos, compatibilização e recuperação. 1998. 157 p. Dissertação (Mestrado) Universidade Federal do Ceará, Departamento de Geologia, Fortaleza, 1998.

DOWN, C.G.; STOCKS, J. Environmental impact of mining. New York: John Wiley, 1977. $371 \mathrm{p}$.

FISHER, B.L. A new species of Discothyrea roger from Mauritius and a new species of Proceratium from Madagascar (Hymenoptera: Formicidae). Proceedings of California Academy of Sciences, San Francisco, n. 56, p. 657-667, 2005.

FOGARAIT, P.J. Ant biodiversity and its relationship to ecosystem functioning: a review. Biodiversity and Conservation, London, v. 7, n. 9, p. 1221-1244, 1998.

FONSECA, F. Os efeitos da mineração sobre o meio ambiente. Brasil Mineral, São Paulo, v.7, p. 74-80, 1989. 
FONSECA, C.G; SILVA, G.J.M.; ARAÚJO, L.S.; SILVA, M.B.M.; FALCÃO, M.A.; DICK, W.W; SILVA, A.L.; SILVA, C.S.; MACÊDO, E.C.D.; MEDEIROS, J.F.; CUNHA FILHO, J.C.; SILVA, M.E.M.; NÓBREGA, R.M.; SILVA, R.A.; CUNHA, L.O. Acompanhamento do plano de controle ambiental (PCA) e acompanhamento do plano de recuperação das áreas degradadas (PRAD) do projeto de lavra e beneficiamento de ilmenita, zirconita e rutilo, em uma área de 1123ha, no Município de Mataraca-PB. Mataraca, Rutilo e Ilmenita do Brasil S.A., 1995a. 52 p. Atividades de out/94 a abril/95.

FONSECA, C.G; SILVA, G.J.M.; ARAÚJO, L.S.; SILVA, M.B.M.; FALCÃO, M.A.; DICK, W.W; SILVA, A.L.; SILVA, C.S.; MACÊDO, E.C.D.; MEDEIROS, J.F.; CUNHA FILHO, J.C.; SILVA, M.E.M.; NÓBREGA, R.M.; SILVA, R.A.; CUNHA, L.O.. Acompanhamento do plano de controle ambiental (PCA) do projeto de lavra e beneficiamento de ilmenita, zirconita e rutilo, em uma área de 1123ha, no município de Mataraca - PB. Mataraca, Rutilo e Ilmenita do Brasil S.A., 1995b. 43 p. Atividades de maio a nov./95. *

FONSECA, C.G; SILVA, G.J.M.; ARAÚJO, L.S.; SILVA, M.B.M.; FALCÃO, M.A.; DICK, W.W; SILVA, A.L.; SILVA, C.S.; MACÊDO, E.C.D.; MEDEIROS, J.F.; CUNHA FILHO, J.C.; SILVA, M.E.M.; NÓBREGA, R.M.; SILVA, R.A.; CUNHA, L.O.. Acompanhamento do plano de controle ambiental (PCA) do projeto de lavra e beneficiamento de ilmenita, zirconita e rutilo, em uma área de 1123ha, no município de Mataraca - PB. Mataraca, Rutilo e Ilmenita do Brasil S.A., 1996. 44 p. Data do protocolo 1996. Atividades de dez/95 a abril/96.

FONSECA, C.G; SILVA, G.J.M.; ARAÚJO, L.S.; SILVA, M.B.M.; FALCÃO, M.A.; ALCÂNTARA; R.M.; SILVA, A.L.; SILVA, C.S.; FARIAS FILHO, E.; MEDEIROS, J.F.; CUNHA FILHO, J.C.; SILVA, M.E.M.; NÓBREGA, R.M.; SILVA, R.A.; CUNHA, L.O. Acompanhamento do plano de controle ambiental (PCA) do projeto de lavra e beneficiamento de ilmenita, zirconita e rutilo, em uma área de 1123ha, no município de Mataraca - PB. Mataraca, Rutilo e Ilmenita do Brasil S.A., 1997a. 13 p. Data do protocolo 1997. Atividades de nov./96 à abril./97.

FONSECA, C.G; SILVA, G.J.M.; ARAÚJO, L.S.; SILVA, M.B.M.; FALCÃO, M.A.; ALCÂNTARA; R.M.; SILVA, A.L.; SILVA, C.S.; FARIAS FILHO, E.; MEDEIROS, J.F.; CUNHA FILHO, J.C.; SILVA, M.E.M.; NÓBREGA, R.M.; SILVA, R.A.; CUNHA, L.O. Acompanhamento do plano de controle ambiental (PCA) do projeto de lavra e beneficiamento de ilmenita, zirconita e rutilo, em uma área de 1123ha, no município de Mataraca - PB. Mataraca, Rutilo e Ilmenita do Brasil S.A., 1997b. 14 p. Data do protocolo 1997. Atividades de maio/97 à nov./97.

FONSECA, C.G. Projeto de re-introdução de animais silvestres em áreas de preservação e recuperação da Titânio do Brasil S.A., no município de Mataraca/PB. [S.I.]: Setor de Meio Ambiente TIBRAS, 1998. 14 p. * 
FOWLER, H.G.; FORTI, L.C.; BRANDÃO, C.R.F.; DELABIE, J.H.C.; VASCONCELOS, H.L. Ecologia nutricional de formigas. In: PANIZZI, A.R.; PARRA, J.R.P. (Ed.). Ecologia nutricional de insetos e suas implicações no manejo de pragas. São Paulo: Manole, 1991. p. 131-209.

FOWLER, H.G.; SCHILINDWEIN, M.N.; MEDEIROS, M.A. Exotics ants and community simplification in Brazil: a review of the impact of exotic ant on native assemblages. In: WILLIAMS, D. F. Exotics ant. Boulder: Westview Press, 1994. p. 151-173.

FOWLER, H.G. Biodiversidade em assembléias locais e regionais de formigas neotropicais arbóreas e epigpeicas (Hymenoptera: Formicidae). 1996. 262 p. Tese (Livre Docência) - Instituto de Biociências, Universidade Estadual Paulista, Rio Claro, 1996.

FOWLER, H.G. Provas de melhoria ambiental. Ciência Hoje, São Paulo, v. 24, n. 142, p. 69-71, 1998.

FOWLER, H.G. Evaluation of ant assemblages (Hymenoptera: Formicidae) in cronological sequencing of bauxite mine-site rehabilitations. Científica, São Paulo, v. 27, n. 1/2, p. 101-115, 1999.

GANDOLFI, S.; RODRIGUES, R.R. Recomposição de florestas nativas: algumas perspectivas metodológicas para o estado de São Paulo. In: CURSO DE ATUALIZAÇÃO: RECUPERAÇÃO DE ÁREAS DEGRADADAS, 3., 1996, Curitiba. Curitiba: UFPR, 1996. p. 83-100.

GONÇALVES, C.R.; NUNES, A.M. Formigas das praias e restingas do Brasil. In: LACERDA, L.D.; ARAÚJO, D.S.D.; CERQUEIRA, R.; TURCQ, B. (Org.). Restingas: origem, estrutura e processos. Niterói: CEUFF, 1984. p. 373-378.

GRAYSON, J.E.; CHAPMAN, M.G.; UNDERWOOD, A.J. The assessment of restoration of habitat in urban wetlands. Landscape and Urban Planning. Amsterdam, v. 43, p. 227-236, 1999.

GREENSLADE, P.J.M. Ants. In: Low, W.A. (Ed.). The physical and biological features of Kunoth Paddock in central Australia. . Camberra: CSIRO Division of Land Resources, 1978. p. 109-113. (Technical Paper, n. 4).

GREENSLADE, P.J.M.; GREENSLADE, P. Invertebrates and environmental assessment. Environmental and Planning. n. 3, p. 13-15, 1984. 
GRIFFITH, J.J. Recuperação conservacionista de superfícies mineradas: uma revisão de literatura. Viçosa: Universidade Federal de Viçosa, 1980. 51 p. (Boletim Técnico SIF, 2).

GRIFFITH, J.J. Recuperação de áreas degradadas em unidades de conservação. Viçosa: Universidade Federal de Viçosa. Departamento. Departamento de Engenharia Florestal, 1986. 4 p.

GRIFFITH, J.J. O estado da arte de recuperação de áreas mineradas no Brasil. In: SIMPÓSIO NACIONAL SOBRE RECUPERAÇÃO DE ÁREAS DEGRADADAS, 1., 1992, Curitiba. Anais. Curitiba: FUNPEF, 1992. p. 77-82.

GRIFFITH, J.J.; DIAS, L.E.; JUCKSCH, I. Novas estratégias ecológicas para a revegetação de áreas mineradas no Brasil. In: SIMPÓSIO NACIONAL SOBRE RECUPERAÇÃO DE ÁREAS DEGRADADAS, 2., 1994, Foz do Iguaçu. Anais. Curitiba: Fupef, 1994. p. 31-43.

GRIFFITH, J.J; DIAS, L.E.; JUCKSCH, I. Recuperação de áreas degradadas usando vegetação nativa. Saneamento Ambiental, São Paulo, v. 7, n. 37, p. 28-37. fev./mar. 1996.

HILTY, J.; MERENLENDER, A. Faunal indicator taxa selection for monitoring ecosystem health. Biological Conservation, Barking, v. 92, n. 2, p. 185-197, 2000.

HÖLLDOBLER, B.; WILSON, E.O. The ants. Harvard: University Press, 1990. $732 \mathrm{p}$.

INSTITUTO BRASILEIRO DO MEIO AMBIENTE E DOS RECURSOS NATURAIS RENOVÁVEIS. Manual de recuperação de áreas degradadas pela mineração: técnicas de revegetação. Brasília: IBAMA, 1990. 96 p.

INSTITUTO BRASILEIRO DE MINERAÇÃO. Comissão Técnica de Meio Ambiente. Mineração e meio ambiente: impactos previsíveis e formas de controle. Belo Horizonte: IBRAM, 1987. $57 \mathrm{p}$.

INSTITUTO BRASILEIRO DE MINERAÇÃO. Comissão Técnica de Meio Ambiente. Mineração e meio ambiente. Brasília: IBRAM, 1992. 111 p.

ISTOCK, C.A., SCHEINER, S.M. Affinities and high-order diversity with landscape mosaics. Evolutionary Ecology, London, v.1, n. 1, p.11-29, Jan. 1987. 
JAMES, A.; EVISON, L. (Ed.) Biological indicators of water quality. Chichester: John Wiley, 1979. $650 \mathrm{p}$.

JESUS, R.M. Revegetação: da teoria à prática. Técnicas de implantação. In: SIMPÓSIO SUL AMERICANO, 1.; SIMPÓSIO NACIONAL DE RECUPERAÇÃO DE ÁREAS DEGRADADAS, 2., 1994, Foz do Iguaçu. Anais. Curitiba: Fundação de Pesquisas Florestais do Paraná, 1994. p. 123-134.

JORDAN III, W.R.; GILPIN, M.E.; ABER, J.D. Restoration ecology: a synthetic approach to ecological research. Cambridge: University Press, 1992. 342 p.

KAGEYAMA, P.Y.; SANTARELLI, E.; GANDARA, F.B.; GONÇALVES, J.C.; SIMIONATO, J.L.; ANTIQUEIRA, L.R.; GERES, W.L. Revegetação de áreas degradadas: modelos de consorciação com alta diversidade. In: SIMPÓSIO SUL AMERICANO, 1.; SIMPÓSIO NACIONAL DE RECUPERAÇÃO DE ÁREAS DEGRADADAS, 2., 1994, Foz do Iguaçu. Anais. Curitiba: Fundação de Pesquisas Florestais do Paraná, 1994. p. 596-576.

KASPARI, M. Introducción a la ecologia de las hormigas. In: FERNÁNDEZ, F. (Ed.). Introducción a las hormigas de la región neotropical. Bogotá: Instituto de Investigación de Recursos Biológicos Alexander von Humboldt, 2003. p. 159-166. Disponível no site: http://www.antbase.org/databases/publications_files/ publications_20239.htm. Acesso em: 05 maio 2006.

KEMPF, W.W. A preliminary zoogeographical analysis of a regional ant fauna in Latin America. Studia Entomologica, Petrópolis, v. 20, n. 1-4, p. 43-62, 1978.

KING, J.R.; ANDERSEN, A.N.; CUTTER, A.D. Ants as bioindicators of habitat disturbance: validation of the functional group model for Australia's humid tropics. Biodiversity and Conservation, London, v. 7, p. 1627-1638, 1998.

KING, J.R.; PORTER, S.D. Evaluation of sampling methods and species richness estimators for ants in upland ecosystems in Florida. Environmental Entomology. College Park, n.34, , n. 6, p.1566-1578, Dec. 2005.

KOLKA, R.K.; NELSON, E.A.; TRETTIN, C.C. Conceptual assessment framework for forested wetland restoration: the Pen Branch experience. Ecological Engineering, Amsterdam, v. 15, p. 17-21, 2000. 
KOPEZINSKI, I. Avaliação da degradação ambiental produzida por mineração no município de Poços de Caldas (MG) considerando procedimentos de mapeamento geotécnico. 1998. 2 v. Dissertação (Mestrado) - Escola de Engenharia de São Carlos, Universidade de São Paulo, 1998.

KREMEN, C.; COLWELL, R.K.; ERWIN, T.L.; MURPHY, D.D.; NOSS, R.F.; SANJAYAN, M.A. Terrestrial arthropod assemblages: their use in conservation planning. Conservation Biology, Boston, v. 7, p. 796-808, 1993.

LIMA, J.S. Bioindicação em ecossistemas terrestres. TEC Hoje. IETEC, 2000a. Disponível em: <http://www.techoje.com.br/materias_tec/meioambiente/tecnologias/ dtml_materia?id=http://www.techoje.com.br/techoje/meioambiente/2003/01/24/2003_ 01_24_0006.2xt>. Acesso em: 11/08/2002.

LIMA, J.S. Bioindicação, biomonitoramento: aspectos bioquímicos e morfológicos. TEC Hoje. IETEC, 2000b. Disponívelem: <http://www.ietec.com.br/ietec/techoje/ techoje/meioambiente/2003/01/24/2003_01_24_0005.2xt/-template_interna>.

Acesso em: 11/08/2002.

LIMA, J.S. Biomonitoramento como ferramenta complementar na avaliação de impactos ambientais. TEC Hoje. IETEC, 2000c. Disponível em: <http://www.ietec.com.br/ietec/techoje/techoje/meioambiente/2003/01/24/2003_01_2 4_0005.2xt/-template_interna>. Acesso em: 11/08/2002.

LUEDERWALDT, $H$. Observações biológicas sobre formigas brasileiras, especialmente do estado de São Paulo. Revista do Museu Paulista, São Paulo, n. 14, p. 185-304, 1926.

MACHADO, P.A.L. Direito ambiental brasileiro. 5. ed. São Paulo: Malheiros Editora, 1995. 231 p.

MAGURRAN, A.E. Ecological Diversity and It's measurement. Princeton University Press. 1988. 167p.

MAIA, A. Titânio. DNPM/PB. 2000. p.111-112. Disponível em: <http://www.dnpm.gov.br/assets/galeriadocumento/sumariomineral2001/TIT\%C3\%82 NIO.doc > Acesso em 2-02-2007. 
MAJER, J.D. Ant manipulation in agro-and forest-ecosystems. In: CONGRESS OF THE INTERNATIONAL UNION FOR THE STUDY OF SOCIAL INSECTS, 9., 1982, Boulder. The biology of social insects: proceedings. Boulder: Westview Press, 1982. p. 91-97.

MAJER, J.D. Ants: bio-indicators of minesite rehabilitation, land-use, and land conservation. Environmental Management, New York, v. 7, n. 4, p. 375-383, July 1983.

MAJER, J.D. Fauna studies and land reclamation technology: a review of the history and need for such studies. In: ANIMALS in primary succession: the role of fauna in reclaimed lands. Cambridge: University Press, 1989. p. 3-33.

MAJER, J.D.; DELABIE, J.H.C.; MACKENZIE, N.L. Ant litter fauna of forest, forest edges and adjacent grassland in the Atlantic rain forest region of Bahia, Brazil. Insectes Sociaux, Paris, v. 44, p. 255-266, 1997.

MAJER, J.D.; DELABIE, J.H.C. Impact of tree isolation on arboreal and ground ant communities in cleared pasture in the Atlantic rain region of Bahia, Brasil. Insectes Sociaux, Paris, v. 46, p. 281-290, 1999.

MCGEOCH, M.A. The selection, testing and application of terrestrial insects as bioindicators. Biological Reviews, Cambridge, v. 73, n. 2, p. 181-201, 1998.

MIRANDA, R.U. Vegetação e banco de sementes em dunas de rejeito de mineração de ilmenita, no litoral norte do estado da Paraíba. 1994. 71 p. Dissertação (Mestrado) - Escola Superior de Agricultura, Universidade Federal de Lavras, Lavras, 1994.

MUNNO, C.M. Análise de monitoramento pós estudo de impacto ambiental no Estado de São Paulo. 2005. 103 p. Dissertação (Mestrado) - Universidade de São Carlos, São Carlos, 2005.

OGLIARI, E.H. Plano de controle ambiental (PCA) na recuperação da rodovia BR-476 no tracho de Bocaiúva do Sul - Trevo do Atuba. 2005. 63 p. Monografia (Graduação) - Centro de Ciências Exatas e Tecnologia, Pontifica Universidade Católica do Paraná, Curitiba, 2005.

OLIVEIRA, C.R.F.; MATOS, C.H.C.; GONÇALVES, J.R. Porque os insetos podem ser considerados bons bioindicadores ecológicos? Folha Florestal, Viçosa, n. 99, p. 12-13, jan./mar. 2001. 
OLIVEIRA FILHO, A.T. Gradient analysis of an area of coastal vegetation in the state of Paraíba, northeasten of Brazil. Edinburg Journal of Botany, Edinburg, v. 50. n. 2, p. 217-236, 1993.

OLIVEIRA FILHO, A.T.; CARVALHO, D.A. Avaliação da recomposição da cobertura vegetal em dunas de rejeito de mineração, em Mataraca/PB. Acta Botânica Brasileira, São Paulo, v. 7, n. 2, p. 107-117, 1993a.

OLIVEIRA FILHO, A.T.; CARVALHO, D.A. Descrição e classificação dos tipos de vegetação do extremo norte do litoral da Paraíba. Revista Brasileira de Botânica, Rio de Janeiro, v.16, n.1, p. 115-130, 1993b.

OLIVEIRA JÚNIOR, J.B.; BRUM, I.A.S. Custos associados a recuperação de áreas degradadas pela mineração. In: CONGRESSO NACIONAL DE MEIO AMBIENTE NA BAHIA, 1., 1998, Feira de Santana. Anais: século XXI - Novos rumos para o meio ambiente. [S.I.]: Espaço Cultural Expogeo, 1998. p. 296-298.

OLIVEIRA JÚNIOR, J.B. Desativação de empreendimentos mineiros: estratégias para diminuir o passivo ambiental. 2001. 179 p. Tese (Doutorado) - Escola Politécnica, Universidade de São Paulo, São Paulo, 2001.

PALMER, M.A.; AMBROSE, R.F.; POFF, N.L. Ecological theory and and community restoration ecology. Restoration Ecology, Oxford, v. 5, n. 4, p. 291-300, 1997.

POGIANI, F.; STAPE, J.L.; GONÇALVES, J.L.M. Indicadores de sustentabilidade das plantações florestais. Série Técnica IPEF, Piracicaba, v. 12, n. 31, p. 33-44. abr. 1998. Resumo do trabalho apresentado ao Workshop sobre Monitoramento Ambiental em Áreas Florestadas, 2., 1998, Piracicaba.

PRABHU, R.; COLFRER, C.J.P.; VENKATESWARLU, P.; TAN, L.C.; SOEKMADI, R.; WOLLENBERG, E. Testing criteria and indicators for sustainable management of forest: phase 1 - final report. Jakarta: CIFOR, 1996. 83 p. (CIFOR Special Publication).

PRADO FILHO, J.F.; SOUZA, M.P. A importância do automonitoramento: parte 1. Brasil Mineral, n. 203, p. 35-43. mar. 2002. 
RÉ, E.R; MARQUES, M.B. Planejamento de lavra para mineração de minerais pesados de titânio. In: X Workshop Datamine, Rio de Janeiro, 2002. Anais. Rio de Janeiro, 2002,13p. Disponível no site: www.datamine.com.br/arquivos/RicardoRe.pdf Acesso em 17-janeiro de 2007.

ROCHA, P.S. Recuperação de áreas degradadas por ação antrópica: utilização de formigas como bioindicadores. 1999. 54 p. Monografia (Graduação) Universidade Estadual Paulista, Rio Claro, 1999.

ROCHA, P.S. Validação de bioindicadores de recuperação de áreas degradadas por minerações de bauxita em Poços de Caldas, MG. 2004. 183 p. Dissertação (Mestrado) - Universidade Estadual Paulista, Rio Claro, 2004.

ROSADO, S.C. Reabilitação de dunas mineradas no litoral norte da Paraíba. Lavras: Departamento de Ciências do Solo da UFLA, 1996. 22 p. (Relatório Técnico).

ROSADO, S.C.S.; FONSECA, C.G; CUNHA, L.O.; SANTOS, M. Relatório das atividades de pesquisas ambientais desenvolvidas pela rutilo e ilmenita do Brasil - RIB. S.A entre maio e outubro de 1994. Local?: Editora, 1994. 33 p. (Relatório Técnico).

ROSADO, S.C.S.; CUNHA, L.O.; SANTOS, M. Parâmetros para monitoramento da evolução e auto-sustentabilidade das áreas em reabilitação pela RIB S.A. Lavras: Departamento de Ciências Florestais, Universidade Federal de Lavras, 1995. 26 p. Período de maio à outubro de 1995. (Relatório Técnico).

ROSADO, S.C.S.; SANTOS, M.; CUNHA, L.O. Monitoramento da evolução e auto-sustentabilidade de dunas em reabilitação. Lavras: Setor de Meio Ambiente. Departamento de Ciências Florestais da UFLA, 1996a. 60 p. (Relatório Técnico, 1/96).

ROSADO, S.C.S.; SANTOS, M.; CUNHA, L.O. Relatório sobre o acompanhamento da reabilitação ambiental das áreas mineradas pela RIB S.A. Lavras: Setor de Meio Ambiente. Departamento de Ciências Florestais, Universidade Federal de Lavras, 1996b. 60 p. (Relatório Técnico no 2/96).

ROSADO, S.C.S.; CUNHA, L.O. Recuperação de sítios perturbados: uma consideração sobre os fatores do solo. Lavras: Setor de Meio Ambiente. Departamento de Ciências Florestais, Universidade Federal de Lavras, 1997. 15 p. (Relatório Técnico). 
SÁNCHEZ, L.E. Gerenciamento ambiental na indústria de mineração. In: SIMPÓSIO NACIONAL DE GERENCIAMENTO AMBIENTAL NA MINERAÇÃO, 3., 1993, São Paulo. Anais. São Paulo: SIGNUS Editora, 1993. p. 127-134.

SÁNCHEZ, L.E. Gerenciamento ambiental na indústria de mineração. Revista de Administração, São Paulo, v. 29, n. 1, p. 67-75, jan./mar. 1994.

SÁNCHEZ, L.E. Projetos de recuperação: usos futuros e a relação com a comunidade. In: ENCONTRO DE MINERAÇÃO NO MUNICÍPIO DE SÃO PAULO, 1., 1994, São Paulo. Anais. São Paulo: SAR/PMSP/EPUSP, 1995. v. 1, p. 53-83.

SÁNCHEZ, L.E. Notas de aula. São Paulo: EPUSP, 2000. 16p. (Material didático relativo à disciplina Recuperação de Áreas Degradadas).

SÁNCHEZ, L.E. Desengenharia: o passivo ambiental na desativação de empreendimentos industriais. São Paulo: EDUSP, 2001. 254 p.

SÁNCHEZ, L.E. Avaliação de impacto ambiental. São Paulo: EPUSPEAD/PECE, 2004. Aula 3 do Curso de Especialização em Gestão e Tecnologias Ambientais, 2004. p. 52-65.

SANTOS, M. Avaliação da recomposição da cobertura vegetal de dunas em recuperação e sua inter-relação com as propriedades físicas, químicas, bioquímicas e microbiológicas do solo. 1996. 81 p. Dissertação (Mestrado) Departamento de Engenharia Florestal, Universidade Federal de Lavras, Lavras, 1996.

SANTOS, M.; ORLANDINI, L.; ROSADO, S.C.S.; OLIVEIRA-FILHO, A.T. Evolução da cobertura vegetal herbáceo-arbustiva em dunas de rejeito de mineração em função da idade e irrigação. In: SIMPÓSIO NACIONAL SOBRE RECUPERAÇÃO DE ÁREAS DEGRADADAS, 3., 1997, Ouro Preto, MG. Anais. Ouro Preto: SOBRADE-SIF, 1997a. p. 292-296.

SANTOS, M.; ORLANDINI, L.; ROSADO, S.C.S.; SIQUEIRA, J.O. Fungos micorrízicos arbusculares em dunas de rejeito, sob processo de recuperação. In: SIMPÓSIO NACIONAL SOBRE RECUPERAÇÃO DE ÁREAS DEGRADADAS, 3., 1997, Ouro Preto, MG. Anais. Ouro Preto: SOBRADE-SIF, 1997b. p. 227-230. 
SARMIENTO-M, C.E. Metodologías de captura y estudio de las hormigas. In: FERNÁN-DEZ, F. (Ed.). Introducción a las hormigas de la región neotropical. Bogotá: Instituto de Investigación de Recursos Biológicos Alexander von Humboldt, 2003.p.201-210.Disponível em:<http://www.antbase.org/databases/publications_files/ publications_20239.htm>. Acesso em: 19-fev.-2006.

SEITZ, R.A. A regeneração natural na recuperação de áreas degradadas. In: SIMPOSIO SUL AMERICANO, 1.; SIMPÓSIO NACIONAL DE RECUPERAÇÃO DE ÁREAS DEGRADADAS, 2., 1994, Foz do Iguaçu. Anais. Curitiba: Fundação de Pesquisa Florestais do Paraná, 1994. p. 216-217.

SEITZ, R.A. As potencialidades da regeneração natural na recuperação de áreas degradadas. Universidade Federal do Paraná. In: CURSO DE ATUALIZAÇÃO, 3., 1996, Curitiba. Recuperação de áreas degradadas. Curitiba: UFPR, 1996. p. 4551.

SILVA, R.R.; SILVESTRE, R. Diversidade de formigas (Hymenopteras Formicidae) em Seara, oeste de Santa Catarina. Biotemas, Florianópolis, v.13, n. 2, p. 85-105, 2000.

SILVESTRE, R.; BRANDÃO, C.R.F. Formigas (Hymenopteras - Formicidae) atraídas a iscas em uma "ilha de cerrado" no Município de Cajuru, Estado de São Paulo, Brasil. Revista Brasileira de Entomologia, São Paulo, v. 44, n. 1/2, p. 71-77, 2000.

SILVESTRE, R.; SILVA, R.R. Guildas de formigas da Estação Ecológica Jataí, Luiz Antônio - SP: sugestões para aplicação do modelo de guildas como bio-indicadores ambientais. Biotemas, Florianópolis, v. 14, n. 1, p. 37-69, 2001.

SILVESTRE, R.; BRANDÃO, C.R.F.; SILVA, R.R. Grupos funcionales de hormigas: el caso de los gremios del Cerrado. In: FERNÁNDEZ, F. (Ed.). Introducción a las hormigas de la región neotropical. Bogotá: Instituto de Investigación de Recursos Biológicos Alexander von Humboldt, 2003. p. 113-148. Disponível no site: http://www.antbase.org/databases/publications_files/publications_20239.htm.

Acesso em: 17 out. 2006.

SIQUEIRA, L.P. Monitoramento de áreas restauradas no interior do Estado de São Paulo. 2002. 116 p. Dissertação (Mestrado) - Escola Superior de Agricultura Luiz de Queiroz, Universidade de São Paulo, Piracicaba, 2002. 
SMITH, M.R.B.; DELABIE, J.H.C.; CAZORLA, I.M.; ENCARNAÇÃO, A.M.U.; CASIMIRO, A.B.; NASCIMENTO, I.C.; SOUZA, A.L.B.; FURST, M. O uso de formigas como bioindicadores: primeiras indicações de padrões de interação entre vegetação, atividade agrícola e comunidades de Formicidae. In: CONGRESSO BRASILEIRO DE ZOOLOGIA, 19; CONGRESSO LATINO-AMERICANO DE ZOOLOGIA, 12., 1992, Belém, PA. Anais. Belém: Universidade Federal do Pará/ Sociedade Brasileira de Zoologia/ Museu Paraense EmilioGoeldi, 1992. p.146-161.

SMITH, T.M.; SCHUGART, H.H.; WOODWARD, F.I. (Eds.). Plant functional types: their relevance to ecosystems properties and global change. Cambridge: University Press, 1997.

SOUZA, J.A. Avaliação das estratégias de recuperação de áreas degradadas pela mineração de bauxita em Poços de Caldas (MG). 1997. 104 p. Tese (Doutorado) - Universidade Federal de Lavras, Lavras, 1997.

TEIXEIRA, M.L.; ROSADO, S.C.S.; OLIVEIRA FILHO, A.T. Projeto de reabilitação ambiental da dunas de rejeito da Rutilo e Ilmenita do Brasil S.A. - RIB. Mataraca-PB. Lavras: Departamento de Ciências Florestais, Universidade Federal de Lavras, 1987. 40 p.

TEIXEIRA, M.L.; FONSECA, C.G. Plano de recuperação da área degradada da mineração RIB - rutilo e ilmenita do Brasil S.A. Mataraca: Rutilo e Ilmenita do Brasil S.A., 1989. 12 p.

TEIXEIRA, M.L.; FONSECA, C.G. Recuperação ambiental de dunas litorâneas mineradas para a obtenção de ilmenita. In: SIMPÓSIO NACIONAL SOBRE RECUPERAÇÃO DE ÁREAS DEGRADADAS, 1., 1992, Curitiba. Anais. Curitiba: UFPR - FUPEF, 1992. p. 373-379.

TEIXEIRA, M.L.; FONSECA, C.G. Recuperação ambiental em dunas litorâneas mineradas para a obtenção de ilmenita. In: WORKSHOP INTERNACIONAL SOBRE RECUPERAÇÃO DE RECURSOS NATURAIS DEGRADADOS PELA MINERAÇÃO, 1995, Brasília. Anais. Brasília: Instituto Brasileiro do Meio Ambiente e dos Recursos Naturais Renováveis, 1995. p. 87-89.

UNDERWOOD, E.C.; FISHER, B.L. The role of ants in conservation monitoring: if, when, and how. Biological Conservation, Barking, v. 132, p. 166-182, 2006.

VASCONCELOS, H.L. Effects of forest disturbance on the struture of ground foraging ant communities in central Amazonia. Biodiversity Conservation, London, v. 8, n. 3, p. 409-420, 1999. 
VASCONCELOS, M.M.T. Diagnóstico da degradação do meio físico e proposição de medidas de recuperação em áreas de mineração abandonadas, na Bacia do Guarapiranga, região metropolitana de São Paulo. 2000. 237 p. Dissertação (Mestrado) - Escola Politécnica, Universidade de São Paulo, São Paulo, 2000.

VIERT, S.R. Design of reclamation to encourage fauna. In: MAJER, J.D. (Coord.). Animals in primary succession: the role of fauna in reclaimed lands. Cambridge: University Press, 1988. p. 207-222.

WILSON, E.O. Causes of ecological success: the case of the ants. Journal of Animal Ecology, London, v. 56, n. 1, p. 1-9, 1987.

WILSON, E.O. The effects of complex social life on evolution and biodiversity. Oikos: a Journal of Ecology, Oxford, v. 63, n. 1, p. 13-18, 1992.

WILSON, E.O. Pheidole in the new world: a dominant, hyperdiverse ant genus. Harvard: University Press, 2003. 802p.

WINK, C.; GUEDES, J.V.C.; FAGUNDES, C.K.; ROVEDDER, A.P. Insetos edáficos como indicadores da qualidade ambiental. Revista de Ciências Agroveterinárias, Harvard, v. 4, n. 1, p. 60-71, 2005.

WOOD, C. Environmental impact assessment: a comparative review. Essex: Longman, 1995.

ZANZINI, A.C.S. Projeto de criação de animais silvestres em viveiros, da Empresa RIB - Rutilo e Ilmenita do Brasil S.A., no município de Mataraca, Estado da Paraíba. Lavras: Universidade Federal de Lavras, 1993. 30 p.

ZANZINI, A.C.S.; TEIXEIRA, M.L.; FONSECA, C.G; CUNHA, L.O.; RONCOLETA, M.; ALVES, R.S. Levantamento preliminar de Formicidae (Insecta Hymenoptera) em dunas litorâneas em diferentes estágios de recuperação. In: SIMPÓSIO SUL AMERICANO, 1.; SIMPÓSIO NACIONAL DE RECUPERAÇÃO DE ÁREAS DEGRADADAS, 2., 1994, Foz do lguaçu. Resumos. Curitiba: Fundação de Pesquisas Florestais do Paraná, 1994. p.657.

\footnotetext{
* Documento acessível mediante autorização da Empresa.
} 


\section{GLOSSÁRIO}

Abiótico - é o componente não vivo do meio ambiente. Inclui as condições físicas e químicas do meio. Lugar ou processo sem seres vivos.

Aeração do solo - 1. A presença de ar no solo é de importância fundamental para a vida das árvores. Todas as partes das árvores necessitam de oxigênio para a respiração. Quanto mais poroso e solto o solo, melhor a aeração. 2. A aeração do solo é a troca de gases entre o solo e a atmosfera.

Anemocoria - Dispersão da semente por ação do vento

Auto-Ecologia - Ecologia de uma espécie específica. Ecologia das espécies consideradas individualmente em oposição ao seu estudo quando integradas em comunidades.

Auto-Sustentabilidade - Capacidade, de um novo ecossistema formado, de se manter sem a influênmcia antrópica. Que se mantem por si só.

Biocenose - Conjunto de organismos, em um ecossistema, cuja composição e aspecto são determinados pelas propriedades do ambiente e pelas relações de uns organismos com os outros. O componente biológico de um ecossistema. Sin. Comunidade Biótica, Comunidade Biológica.

Bioindicador - 1. Organismo usado como indicador de atividade química ou da composição de um sistema natural. 2. Organismo com distribuição geográfica estreita vivendo exclusiva ou preferencialmente em determinados ambientes, e capazes, portanto, de caracterizar as propriedades físicas e químicas desse ambiente. Sin. Organismo Indicador, Indicador Biológico de Ambiente.

Bioma - Amplo conjunto de ecossistemas terrestres, caracterizado por tipos fisionômicos semelhantes de vegetação com diferentes tipos climáticos. 
Biomassa: quantidade de matéria orgânica presente num dado momento numa determinada área, e que pode ser expressa em peso, volume, área ou número.

Biota - Conjunto de seres vivos que habitam um determinado ambiente ecológico, em estreita correspondência com as características físicas, químicas e biológicas desse ambiente. Conjunto de plantas e animais de uma determinada região, província ou área biogeográfica.

Biótico - É o componente vivo do meio ambiente. Inclui a fauna, flora, vírus, bactérias, etc.

Biótopo - É o espaço ocupado pela biocenose. O microhabitat, ou lugar, substrato, microclima e situação exatos de uma espécie, dentro de uma comunidade. Habitat costumeiro de uma determinada espécie vegetal ou animal.

Carnívoros - Que se alimenta de carne.

Competição - Quando duas espécies ou dois indivíduos lutam pelo mesmo bem essencial (alimentação, luz, espaço) eles estão em competição, uma lei básica da natureza. As árvores dominantes de uma floresta, por exemplo, conseguem mais luminosidade por causa de sua altura, enquanto as dominadas devem adequar-se à pouca luz - e a sua não adaptação significa a morte.

Complexidade estrutural - Grupo ou conjunto de espécies ocorrentes em uma floresta, cujos indivíduos interagem imprimindo características próprias a mesma em virtude de distribuição e abundância de espécies, formação de extratos, diversidade biológica.

Detritívoro - Que se alimenta de detritos, ou seja, restos de organismos e detritos inorgânicos.

Dispersão - 1. Ato de espalhar diásporos (sementes, esporos, fragmentos vegetativos) de um organismo individual ou de uma espécie; 2. Movimentos não direcionais, normalmente em pequena escala, que resultam das atividades diárias dos indivíduos; Processo em que o indivíduo é passivamente transportado para outras áreas. Ocorre principalmente com frutos e sementes. 
Distúrbio - Ação de disturbar, perturbar.

Dominância de espécies - Grau em que determinadas espécies dominam em uma comunidade, devido ao tamanho, abundância ou cobertura, e que afeta as potencialidades das demais espécies.

Dossel - Na estrutura da vegetação é o estrato superior da formação vegetal da região, em uma visão coletiva. Camada de folhagem contínua em uma floresta, arvoredo ou cerradão, composta pelo conjunto de copas lenhosas mais altas. Aplicável, sobretudo à vegetação mais fechada.

Ecossistema - A comunidade total de organismos, junto com o ambiente físico e químico no qual vivem se denomina ecossistema, que é a unidade funcional da ecologia; conjunto de fatores físicos, químicos e bióticos que compõem determinado ambiente, que se estende por um espaço dado de dimensões variáveis.

Epífitas - Qualquer espécie vegetal que cresce ou se apóia fisicamente sobre outra planta ou objeto, retirando seu alimento da chuva ou de detritos e resíduos que coleta de seu suporte. "Planta que cresce sobre a outra planta sem retirar alimento ou tecido vivo do hospedeiro" (Resolução oํ 12, de 4.05.94, do CONAMA).

Equilíbrio ecológico - aquele existente em uma população de tamanho estável na qual as taxas de mortalidade e emigração são compensadas pelas taxas de natalidade e imigração.

Eqüitatividade - Distribuição dos indivíduos pelas espécies, numa comunidade. Um dos componentes da diversidade, que pode por si só ser indicativo de dominância numérica relativa.

Espécie Generalista - Espécie que utiliza efetivamente uma ampla faixa do conjunto de recursos ou fatores ambientais potencialmente disponíveis.

Espécies Nativas - aquela que suposta ou comprovadamente é originária da área geográfica em que atualmente ocorre. 
Espécies Oportunistas - 1. Aquela que apresenta estratégia adaptativa caracterizada por grande flexibilidade, sem especialização acentuada para nenhuma situação ambiental permanente ou particular, porém capaz de aproveitar eficientemente qualquer recurso. 2. Aquela capaz de colonizar rapidamente espaços desabitados, ambientes efêmeros ou sujeitos à perturbação, sem conseguir ocupálos indefinidamente. Possui alta taxa de crescimento populacional, duração de vida curta, alto potencial de dispersão e baixa capacidade competitiva.

Estrato - (1) Determinada camada de vegetação que constitui o habitat de determinadas espécies. (2) Situações verticais em que se dispõem as plantas lenhosas dentro da comunidade, avaliadas em metros.

Estrutura Trófica - Relação trófica ou nutricional, entre os seres vivos que fazem parte de um ecossistema, através da qual se transfere a energia de um organismo para outro. Sin. Cadeia Trófica, Cadeia Alimentar.

Fauna silvestre - Conjunto de animais que vivem livres em seu ambiente natural.

Fitomassa - Parte vegetal da biomassa. Qualquer estimativa quantitativa da massa total vegetal numa plantação, população ou numa área, num dado tempo.

Fitotóxico - 1. Veneno de planta. 2. Toxina produzida por plantas.

Fluxo de Energia - É a seqüência de transferência de energia, de organismo para organismo, em forma de alimentação. Sin. Fluxo Energético.

Forrageio - Atividade locomotora que é prontamente interrompida pelo encontro do recurso alimentar. Sin. Forrageamento.

Habitat - 1. Ambiente que oferece um conjuno de condições favoráveis para o desenvolvimento, sobrevivência e reprodução de determinados organismos; 2. Tipo de ambiente caracterizável em termos das condições bióticas e abióticas apresentadas.

Herbívoros - Diz-se do animal que se alimenta de ervas ou de vegetais. 
Indicadores - Nas ciências ambientais, indicador significa um organismo, uma comunidade biológica ou outro parâmetro (físico, químico, social) que serve como medida das condições de um fator ambiental, ou um ecossistema. Aquela cuja presença em um ambiente está correlacionada com alguma condição ou conjunto de condições físicas, químicas ou bióticas particulares, e que é utilizada para indicar a existência de tal condição nos ambientes em que ocorre. Sin. Espécie Indicadora.

Interespecífico - Entre espécies diferentes.

Inventário de espécies - Censo da flora ou da fauna que habita determinada área. O nível de resolução de tal censo depende dos objetivos do estudo, desde uma lista das espécies predominantes a outra completa.

Microhabitats - Pequeno habitat especializado. Sin. Micro ambiente.

Mutualista - Interação obrigatória ou facultativa entre duas espécies, com benefício mútuo, de tal modo que a aptidão dos indivíduos de ambas as espécies tende, em média, a ser maior do que se elas vivessem isoladamente.

Nicho - 1. papel ecológico de uma espécie em uma comunidade; conceituando como espaço multidimencional, cujas coordenadas são os vários parâmetros que constituem a condição de existência da espécie; 2. Gama total de condições sobre as quais o indivíduo ou a população vive e se reproduz; 3. microhabitat.

Nidificar - Fazer ninho.

Nível Estrutural - é a posição ocupada por um organismo no estrato da vegetação.

Nível trófico - ou nível alimentar, é a posição ocupada por um organismo na cadeia alimentar. Os produtores ocupam o primeiro nível, os conumidores primárioso segundo nível, os secundários o terceiro nível e assim por diante. Os decompositores podem atuar em qualque nível trófico. Posição de um organismo em uma cadeia alimentar: produtor primário, consumidor primário, decompositor, predador, etc

Plântulas - s.f. Embrião de uma planta contido numa semente. Plantinha recém nascida. 
Predador - Ser que pratica a predação: relação alimentar entre organismos de espécies diferentes, benéfica para um deles (predador), à custa da morte e consumo de outros (presa).

Rapina - Ação ou hábito de rapinar (roubar, tirar com violência).

Reciclagem de Nutrientes - Processo de renovação de nutrientes que ocorre nos ecossistemas num determinado período, por ação dos mais variados fatores como circulação, ação de organismos, temperatura.

Regeneração - Ato ou efeito de regenerar. Tornar a gerar, restaurar, reorganizar, melhorar, formar-se de novo.

Riqueza de Espécies - 1. Número de Espécies em área padrão. Conceito mais antigo e fundamental de diversidade. Sin. Diversidade em espécies. 2. Espécie por número fixo de indivíduo. 3. Um dos componentes da diversidade. 4. Indicador de abundância relativa de espécies numa comunidade. Qualquer medida de riqueza tem dependência inerente do tamanho da amostra.

Serapilheira - Camada sob cobertura vegetal, consistindo de folhas caídas, ramos, caules, casca e frutos depositados sobre o solo. Equivalente ao horizonte $\mathrm{O}$ dos solos minerais.

Subosque - Estratos inferiores de uma floresta. Vegetação que cresce sob as árvores.

Sucessão - Processo de substituição de uma comunidade por outra, conseqüente à modificação do ambiente e ao desequilíbrio que pode ocorrer uma vez atingido o nível de saturação.

Sucessão Ecológica - Seqüência de comunidades que se substituem, de forma gradativa, num determinado ambiente, até o surgimento de uma comunidade final, estável denominada comunidade-clímax.

Sucessão Primária - Tipo de sucessão ecológica iniciada em um local inteiramente desabitado e sem a influência de organismos que eventualmente o tenham habitado em época anterior. 
Sucessão Secundária - Tipo de sucessão ecológica iniciada em área habitada, após ocorrência de perturbação, e influenciada pelo tipo de comunidade previamente existente.

Sustentabilidade - Uma característica de um processo ou estado que pode ser mantido indefinitivamente. Manejo do ambiente e seus recursos de modo a que seu uso possa ser contínuo sem diminuição num futuro indefinido.

Táxon - Nível de organização dentro de um sistema taxonômico. Exemplo: espécie, gênero, família.

Vida silvestre - Todos os mamíferos, aves, répteis e anfíbios não domésticos que vivem em seu ambiente natural.

\section{REFERÊNCIAS}

DICIONÁRIO ecológico ambiental Eco News, [1999]. Disponível em:<http://www.ecolnews.com.br/dicionarioambiental/> Acesso em: 05 jan 2007.

FERNANDES, F.; LUFT, C.P.; GUIMARÃES, F.M. Dicionário brasileiro Globo. 40. ed. São Paulo: Editora Globo, 1995.

GLOSSÁRIO ambiental. Jornal diário Ambiente Brasil, [1999]. Disponível em:<http://www.ambientebrasil.com.br/glossario > Acesso em: 05 jan 2007.

GLOSSÁRIO de ecologia. 2. ed. rev. e ampl. São Paulo: Academia de Ciências do Estado de São Paulo/ Conselho Nacional de Desenvolvimento Científico e Tecnológico, 1997. 352 p. (Publicação ACIESP, 103).

GLOSSÁRIO ecológico. São Carlos: CDCC-USP, [1996]. In: CIENCIAS para professores do ensino fundamental - Modulo Ecologia: ecossistema e cadeia alimentar. Disponível em: <http://educar.sc.usp.br/ciencias/ecologia/glossario.html> Acesso em: 05 jan. 2007. 
GLOSSÁRIO Secretaria do Meio Ambiente do Estado do Rio Grande do Sul, [2002]. Disponível em <http://www.sema.rs.gov.br/sema/html/glossa.htm> Acesso em: 05 jan 2007.

GLOSSÁRIO de zoologiaecologia. Salvador: UFBA, [2000]. Disponível em:<http://www.faced.ufba.br/ dacn/glozool.htm>. Acesso em: 05 jan. 2007. 
APÊNDICE A - Listagem de espécies das formigas (Subfamília, Tribo, Gênero e Espécie) coletadas na área de estudo.

\begin{tabular}{|c|c|c|c|}
\hline Subfamílias & Tribos & Gêneros & Espécies \\
\hline \multirow[t]{2}{*}{ Myrmicinae } & \multirow[t]{2}{*}{ Attini } & Acromyrmex & balzani \\
\hline & & Acromyrmex & sp. 01 \\
\hline Ponerinae & Ponerini & Anochetus & sp. 01 \\
\hline Myrmicinae & Attini & Atta & laevigata \\
\hline \multirow[t]{12}{*}{ Formicinae } & \multirow[t]{2}{*}{ Brachymyrmicini } & Brachymyrmex & $s p .01$ \\
\hline & & Brachymyrmex & sp.02 \\
\hline & \multirow[t]{10}{*}{ Camponotini } & Camponotus & atriceps \\
\hline & & Camponotus & blandus \\
\hline & & Camponotus & crassus \\
\hline & & Camponotus & leydigi \\
\hline & & Camponotus & melanoticus \\
\hline & & Camponotus & sp.01 \\
\hline & & Camponotus & sp.02 \\
\hline & & Camponotus & $s p .03$ \\
\hline & & Camponotus & tenuiscapus \\
\hline & & Camponotus & vittatus \\
\hline \multirow[t]{11}{*}{ Myrmicinae } & \multirow[t]{4}{*}{ Cephalotini } & Cephalotes & pusillus \\
\hline & & Cephalotes & sp. 01 \\
\hline & & Cephalotes & sp.02 \\
\hline & & Cephalotes & sp.03 \\
\hline & \multirow[t]{3}{*}{ Crematogastrini } & Crematogaster & acuta \\
\hline & & Crematogaster & sp.01 \\
\hline & & Crematogaster & sp.02 \\
\hline & \multirow[t]{4}{*}{ Attini } & Cyphomyrmex & bicornies \\
\hline & & Cyphomyrmex & transversus \\
\hline & & Cyphomyrmex & sp.01 \\
\hline & & Cyphomyrmex & sp.02 \\
\hline \multirow[t]{2}{*}{ Dolichoderinae } & \multirow[t]{2}{*}{ Dolichoderini } & Dorymyrmex & pyramicus \\
\hline & & Dorymyrmex & sp.01 \\
\hline \multirow[t]{4}{*}{ Ponerinae } & \multirow[t]{4}{*}{ Ectatommini } & Ectatomma & edentatum \\
\hline & & Ectatomma & sp.01 \\
\hline & & Gnamptogenys & sp.01 \\
\hline & & Gnamptogenys & striatula \\
\hline \multirow[t]{2}{*}{ Myrmicinae } & \multirow[t]{2}{*}{ Myrmicini } & Hylomyrma & sp.01 \\
\hline & & Hylomyrma & sp.02 \\
\hline
\end{tabular}




\section{APÊNDICE A - Listagem de espécies das formigas (Subfamília, Tribo, Gênero e Espécie) coletadas na área de estudo.}

\begin{tabular}{|c|c|c|c|}
\hline Subfamílias & Tribo & Gênero & Espécies \\
\hline Ponerinae & Ponerini & Hypoponera & sp.01 \\
\hline Ecitoninae & Ecitonini & Labidus & coecus \\
\hline Myrmicinae & Formicoxenini & Leptothorax & $s p .01$ \\
\hline Dolichoderinae & Dolichoderini & Linepithema & sp. 01 \\
\hline Ponerinae & Ponerini & Odontomachus & haematodus \\
\hline Ponerinae & Ponerini & Pachycondyla & $s p .01$ \\
\hline Formicinae & Lasiini & Paratrechina & fulva \\
\hline \multirow[t]{11}{*}{ Myrmicinae } & \multirow[t]{11}{*}{ Pheidolini } & Pheidole & sp.01 \\
\hline & & Pheidole & sp.02 \\
\hline & & Pheidole & sp.03 \\
\hline & & Pheidole & sp.04 \\
\hline & & Pheidole & sp.05 \\
\hline & & Pheidole & sp.06 \\
\hline & & Pheidole & sp.07 \\
\hline & & Pheidole & sp.08 \\
\hline & & Pheidole & sp.09 \\
\hline & & Pheidole & sp. 10 \\
\hline & & Pheidole & $s p .11$ \\
\hline Ponerinae & Ponerini & Ponera & $s p .01$ \\
\hline \multirow{3}{*}{ Pseudomyrmicinae } & \multirow[t]{3}{*}{ Pseudomyrmicini } & Pseudomyrmex & flavidulus \\
\hline & & Pseudomyrmex & gracillus \\
\hline & & Pseudomyrmex & termitarius \\
\hline \multirow[t]{15}{*}{ Myrmicinae } & Stenammini & Rogeria & sp.01 \\
\hline & \multirow[t]{5}{*}{ Solenopsini } & Solenopsis & sp.01 \\
\hline & & Solenopsis & sp.02 \\
\hline & & Solenopsis & sp.03 \\
\hline & & Solenopsis & sp.04 \\
\hline & & Solenopsis & sp.05 \\
\hline & \multirow[t]{4}{*}{ Dacetini } & Strumigenys & $s p .01$ \\
\hline & & Strumigenys & sp.02 \\
\hline & & Strumigenys & sp.03 \\
\hline & & Strumigenys & sp.04 \\
\hline & \multirow[t]{3}{*}{ Attini } & Trachymyrmex & sp.01 \\
\hline & & Trachymyrmex & sp.02 \\
\hline & & Trachymyrmex & $s p .03$ \\
\hline & \multirow[t]{2}{*}{ Blepharidattini } & Wasmannia & auropunctata \\
\hline & & Wasmannia & $s p .01$ \\
\hline
\end{tabular}


ANEXO A - Mapa do Limite das áreas do Decreto de Lavra: área de lavra e área de servidão ${ }^{65}$.

${ }^{65}$ Mapa fornecido pelo Setor de Meio Ambiente da Mina do Guaju - Lyondell Chemicals Company, em 20 de janeiro de 2003. 
ANEXO B - Mapa de vegetação ${ }^{66}$.

${ }^{66}$ Mapa fornecido pelo Setor de Meio Ambiente da Mina do Guaju - Lyondell Chemicals Company, em 20 de janeiro de 2003. 


\section{ANEXO C - Listagem de espécies produzidas para o plantio de}

\section{2.}

\begin{tabular}{|c|c|c|}
\hline N. & Espécie & Nome comum \\
\hline 1 & Acacia mangium & Acacia \\
\hline 2 & Aechmaea stephanophora & Bromélia \\
\hline 3 & Allophylus puberulus & Cumixar-branco \\
\hline 4 & Anacardium ocidentalle & Cajueiro-nativo \\
\hline 5 & Anthurium harisii & Antúrio-da-praia \\
\hline 6 & Apeiba tibourbou & Pau-de-jangada \\
\hline 7 & Arikuryroba schisophylla & Aricuri \\
\hline 8 & Astrocaryum fraxinifolium & Ticum \\
\hline 9 & Bauhinia rubiginosa & Mororó \\
\hline 10 & Byrsonima gardneriana & Murici-da-praia \\
\hline 11 & Bowdichia virgilioides & Sucupira \\
\hline 12 & Britoa triflora & Guabiraba \\
\hline 13 & Brosimum gaudichaudii & Conduru \\
\hline 14 & Buchenavia capitata & Imbiridiba \\
\hline 15 & Chamaecrista bahiae & Pau-ferro \\
\hline 16 & Chrysobalanus icaco & Guajiru \\
\hline 17 & Cecropia obtusa & Embaúba \\
\hline 18 & Caesalpinia echinata & Pau-brasil \\
\hline 19 & Calotropis procera & Algodão-de-seda \\
\hline 20 & Capparis flexuosa & Feijão-da-praia \\
\hline 21 & C. pernambucensis & Cactus \\
\hline 22 & Calicorectes sellowianum & Azeitona-do-mato \\
\hline 23 & Calyptranthes lucida & Purpuna \\
\hline 24 & Capparis flexuosa & Feijão-da-praia \\
\hline 25 & Coccoloba vellosiana & cavaçu rasteiro \\
\hline 26 & Coccoloba latifolia & cavaçu da mata \\
\hline 27 & Coccoloba cordifolia & Garajao \\
\hline 28 & Cupania revoluta & Cabatã \\
\hline 29 & Casearia sylvestris & Espeto \\
\hline 30 & Calateia sp. & Araruta \\
\hline 31 & Cereus pernambucensis & Cactos \\
\hline 32 & Diospyros inconstans & Café-da-praia \\
\hline 33 & Eugenia ovalifolia & Pau-branco-praia \\
\hline 34 & Eugenia insipida & Murta-branca \\
\hline 35 & Erythroxylum sp. & Coca-falsa \\
\hline 36 & Erythroxylum andrei & Cumixar-preto \\
\hline 37 & Faramea sp & Canela-de-veado \\
\hline 38 & Ficus gomeleira & Gameleira \\
\hline 39 & Guetarda platypoda & Angélica \\
\hline 40 & Guapira pernambucensis & Cipó-da-praia \\
\hline
\end{tabular}

\begin{tabular}{|c|c|c|}
\hline N. & Espécie & Nome comum \\
\hline 41 & Guazuma ulmifolia & Mutamba \\
\hline 42 & Hippeastrum stylosum & Lírio \\
\hline 43 & Hymeneae courbaril & Jatobá \\
\hline 44 & Ingá capitata & Ingá-tripa \\
\hline 45 & Jaquinia brasiliensis & Tingui-da-praia \\
\hline 46 & Mimosa caesalpiniaefolia & Sabiá \\
\hline 47 & Manihot sp. & Maniçoba \\
\hline 48 & Manilkara salzmannii & Massaranduba \\
\hline 49 & Maytenus distichophylla & Bom-nome \\
\hline 50 & Maytenus erythroxylum & Cuião-de-bode \\
\hline 51 & Merremia glabra & Jetirana \\
\hline 52 & Ocotea sp. & Louro-branco \\
\hline 53 & Ormosia arborea & Mucunã \\
\hline 54 & Olyra sp. & Taboquinha \\
\hline 55 & Psidium sp. & Pau-mulato \\
\hline 56 & Psidium sp. & Batinga \\
\hline 57 & Protium heptaphyllum & Amescla \\
\hline 58 & Phylodendron imbe & Imbé \\
\hline 59 & Pithecelobium cochiocarpum & Barbatimão \\
\hline 60 & Pithecelobim pedicelare & Jurema-branca \\
\hline 61 & Passiflora sp. & Maracujá-mochila \\
\hline 62 & Pouteria margionata & Goiti \\
\hline 63 & Psidium sp. & Falsa-batinga \\
\hline 64 & Psidium decussatum & Batinga \\
\hline 65 & Smilax brasiliensis & Japecanga \\
\hline 66 & Solanum mauritianum & Jussara \\
\hline 67 & Solanum paludosusm & Jurubeba-amarela \\
\hline 68 & Sporolobus virginicus & Capim-da-praia \\
\hline 69 & Simaba ferrugínea & Cajarana-da-praia \\
\hline 70 & Sacoglottis mattogrossenssis & Oiticica-de-morcego \\
\hline 71 & Tocoyena selloana & Jenipapo-bravo \\
\hline 72 & Tapirira guianensis & Cupiúba \\
\hline 73 & Thalia geniculata & Arararuta-brava \\
\hline 74 & Tabebuia chrysotricha & Ipê-amarelo \\
\hline 75 & Tetracera breyniana & Cipó-de-fogo \\
\hline 76 & Tabebuia avelanedae & Ipê-roxo \\
\hline 77 & Tabebeuia roseo-alba & Ipê-branco \\
\hline 78 & Xylopia nitida & Camaçari \\
\hline 79 & Ziziphus joazeiro & Juazeiro \\
\hline 80 & Zollernia ilicifolia & Pau-santo \\
\hline
\end{tabular}

Fonte: informação pessoal ${ }^{6}$

${ }^{67}$ Dados fornecidos pelo Setor de Meio Ambiente da Mina do Guaju - Lyondell Chemicals Company, em 20 de janeiro de 2003. 
ANEXO D - Mapa de delimitação dos plantios: de 1989 a $2002{ }^{68}$.

${ }^{68}$ Mapa fornecido pelo Setor de Meio Ambiente da Mina do Guaju - Lyondell Chemicals Company, em 20 de janeiro de 2003. 


\section{ANEXO E - Classificação dos grupos funcionais das formigas do Chaco argentino.}

\begin{tabular}{|c|c|c|}
\hline Subfamílias & Gêneros & Grupos Funcionais \\
\hline \multirow[t]{7}{*}{ Ponerinae } & Acanthoponera & Oportunistas \\
\hline & Anochetus & Espécies Crípticas \\
\hline & Ectatomma & Oportunistas \\
\hline & Gnamptogenys & Oportunistas \\
\hline & Hypoponera & Espécies Crípticas \\
\hline & Odontomachus & Predadoras \\
\hline & Pachycondyla & Predadoras \\
\hline \multirow[t]{4}{*}{ Ecitoninae } & Eciton & Ecitonini \\
\hline & Labidus & Ecitonini \\
\hline & Neivamyrmex & Ecitonini \\
\hline & Nomamyrmex & Ecitonini \\
\hline Pseudomyrmicinae & Pseudomyrmex & Arboreal \\
\hline \multirow[t]{15}{*}{ Myrmicinae } & Acromyrmex & Arboreal \\
\hline & Apterostigma & Attini \\
\hline & Atta & Attini \\
\hline & Crematogaster & $\begin{array}{l}\text { Myrmicines } \\
\text { Generalistas }\end{array}$ \\
\hline & Cyphomyrmex & Attini \\
\hline & Leptothorax & Espécies Crípticas \\
\hline & Mycetophylax & Attini \\
\hline & Pheidole & Espécies Crípticas \\
\hline & Pogonomyrmex & $\begin{array}{l}\text { Myrmicines } \\
\text { Generalistas }\end{array}$ \\
\hline & Rogeria & Espécies Crípticas \\
\hline & Smithistruma & Espécies Crípticas \\
\hline & Solenopsis & $\begin{array}{l}\text { Myrmicines } \\
\text { Generalistas }\end{array}$ \\
\hline & Trachymyrmex & Attini \\
\hline & Wasmannia & Espécies Crípticas \\
\hline & Zacryptocerus & Arboreal \\
\hline \multirow[t]{2}{*}{ Dolichoderinae } & Dorymyrmex & Oportunistas \\
\hline & Forelius & Espécies Crípticas \\
\hline \multirow[t]{2}{*}{ Formicinae } & Brachymyrmex & Espécies Crípticas \\
\hline & Camponotus & Camponotus \\
\hline
\end{tabular}

Fonte: Bestelmeyer e Wiens (1996). 